
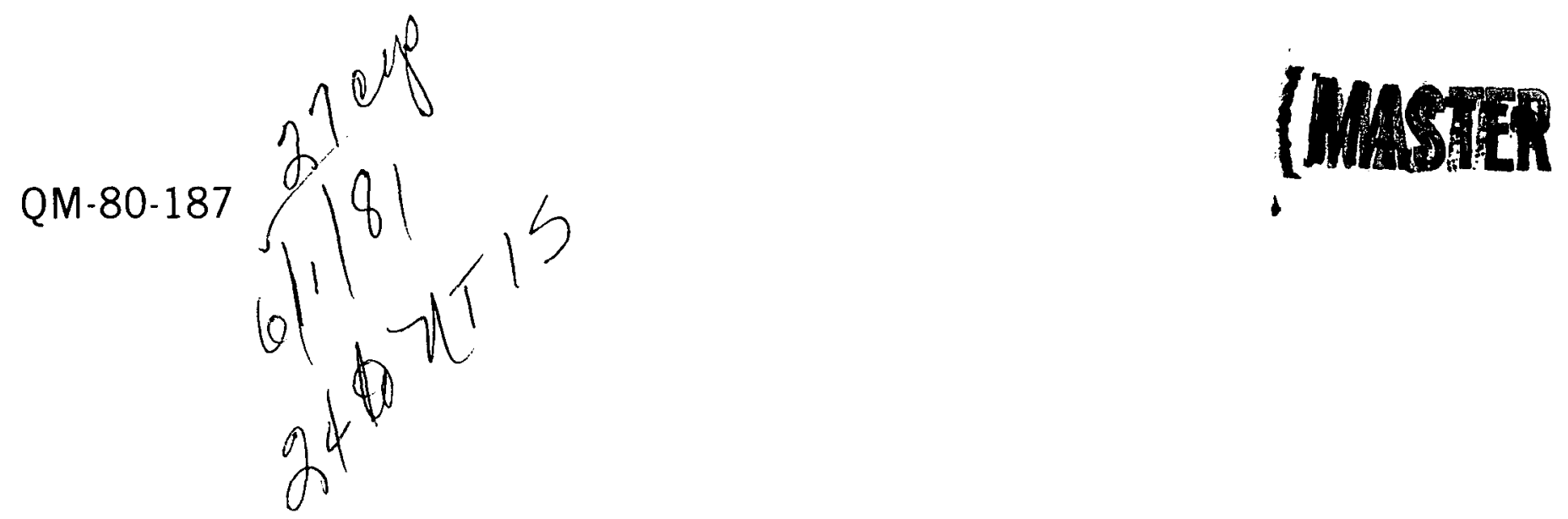

\title{
FACT SHEETS \\ RELATING TO USE OF GEOTHERMAL ENERGY \\ IN THE UNITED STATES
}

DECEMBER 1980

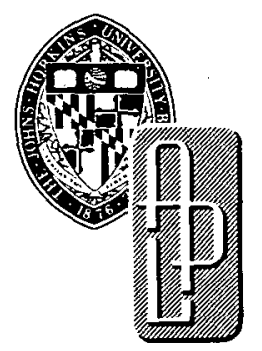

Prepared for the DEPARTMENT OF ENERGY by

Applied Physics Laboratory The Johns Hopkins University Laurel, Maryland 20810 


\section{DISCLAIMER}

This report was prepared as an account of work sponsored by an agency of the United States Government. Neither the United States Government nor any agency Thereof, nor any of their employees, makes any warranty, express or implied, or assumes any legal liability or responsibility for the accuracy, completeness, or usefulness of any information, apparatus, product, or process disclosed, or represents that its use would not infringe privately owned rights. Reference herein to any specific commercial product, process, or service by trade name, trademark, manufacturer, or otherwise does not necessarily constitute or imply its endorsement, recommendation, or favoring by the United States Government or any agency thereof. The views and opinions of authors expressed herein do not necessarily state or reflect those of the United States Government or any agency thereof. 


\section{DISCLAIMER}

Portions of this document may be illegible in electronic image products. Images are produced from the best available original document. 
Department of Energy

Division of Geothermal Energy

12th and Pennsylvania Avenue, N.W.

Washington, D.C. 20461

Attention: Mr. Fred Abel

Subject: Forwarding of Revised Geothermal Energy Fact Sheets -State of Alabama

Reference: JHU/APL QM-80-187, December 1980 -- "Fact Sheets Relating to Use of Geothermal Energy in the United States"

Dear Sir:

Please find as enclosure the revised Fact Sheets for the State of Alabama to replace those in the referenced report. Other states are encouraged to keep the description of their geothermal effort and documentation of their state up-to-date. The Laboratory will provide a service of publishing and distributing these revised state fact sheets through September of this year. After that time, it is suggested that revisions be forwarded to your office.

By copy of this letter, the Alabama Fact Sheets are forwarded to interested parties. A distribution list is kept on file at this Laboratory and at the Department of Energy, Division of Geothermal Energy.

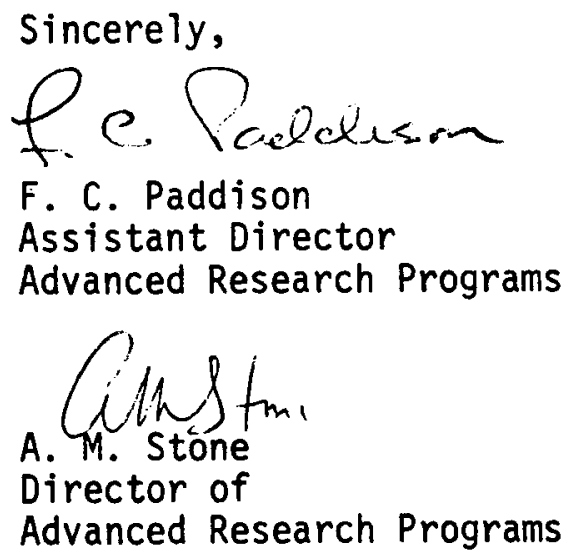

FCP:sa 


\section{GEOTHERMAL DLATA SUMMARY SHEET}

\begin{tabular}{|c|c|c|}
\hline \multicolumn{3}{|c|}{ ESOURCE : } \\
\hline NMME & (1) & (2) \\
\hline TYPE & clastic sedinents & Clastic sedinentary \\
\hline DEPTH & Excess of $20,000 \mathrm{ft}$ & $10,000 \mathrm{ft}$. \\
\hline WAIER TEEPS. & Over $340^{\circ} \mathrm{F}$ & $\begin{array}{lll}180^{\circ} \mathrm{F} \\
\end{array}$ \\
\hline $\begin{array}{l}\text { EST. STORED } \\
\text { EARRR }\end{array}$ & $2 \times 10^{14} \mathrm{cu} . \mathrm{ft}$. & $8 \times 10^{12}$ cu. ft. \\
\hline 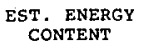 & Over $1,000 \times 10^{15} \mathrm{Btu}$ & $300 \times 10^{15} \mathrm{Btu}$ \\
\hline
\end{tabular}

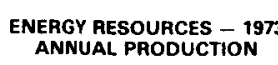

\begin{tabular}{|c|c|c|c|}
\hline TYPE & NUMBER & status & $\begin{array}{lll}10^{12} & \mathrm{Btu}\end{array}$ \\
\hline Coal Mines & 248 & 26,403 thousand tons & 707 \\
\hline Natural Gas (11q-) & 92 & 12,340 thousand bb1 & 48 \\
\hline Natural Gas we11s & 222 & $130,000 \mathrm{mi} 111 \mathrm{ion}$ cu. $\mathrm{ft}$. & 132 \\
\hline Crude oil wel1s & 684 & 9,813 thousand bb1 & 56.9 \\
\hline
\end{tabular}

ENERGY USE - 1995 110" BTU

\begin{tabular}{|c|c|c|c|c|c|}
\hline SEctor & OIL & LPG & GAS & COAL & 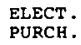 \\
\hline GROSS & 420.4 & 20.9 & 286.4 & 683.9 & 142.0 \\
\hline RES IDENTIAL & 6.6 & 26.6 & 54,0 & 0.2 & 47.6 \\
\hline COMMERCAAI & 29.2 & 1.9 & 34.5 & 0.1 & 22.3 \\
\hline INDUSTRTAL & 38.2 & 2.3 & 174.4 & 59.8 & 72.1 \\
\hline PERCENT & 30 & 1 & 20 & 48 & \\
\hline
\end{tabular}

GEOTHERMAL ACTVUTIES

\begin{tabular}{|c|c|}
\hline CURRENT USES & 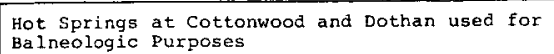 \\
\hline 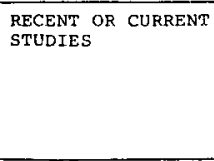 & 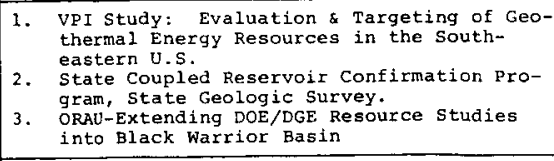 \\
\hline PRoOPOS & \\
\hline
\end{tabular}

LEGAL ACTMVITE

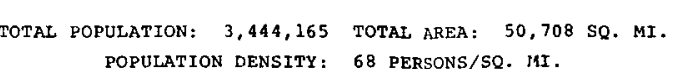

GEOTHERMAL OVERVIEW

Thick sedimentary cover in the southern and western por
Thes of the state contain shall ow hydrothermal aquifers lions of the state contain shall ow hydrothermal aquifers radients Deeper aduiters are also knewn than normal surface thermal data are being compiled by State Coupled State Geologic Survey. Data on geopressured regions

\section{ALABAMA}

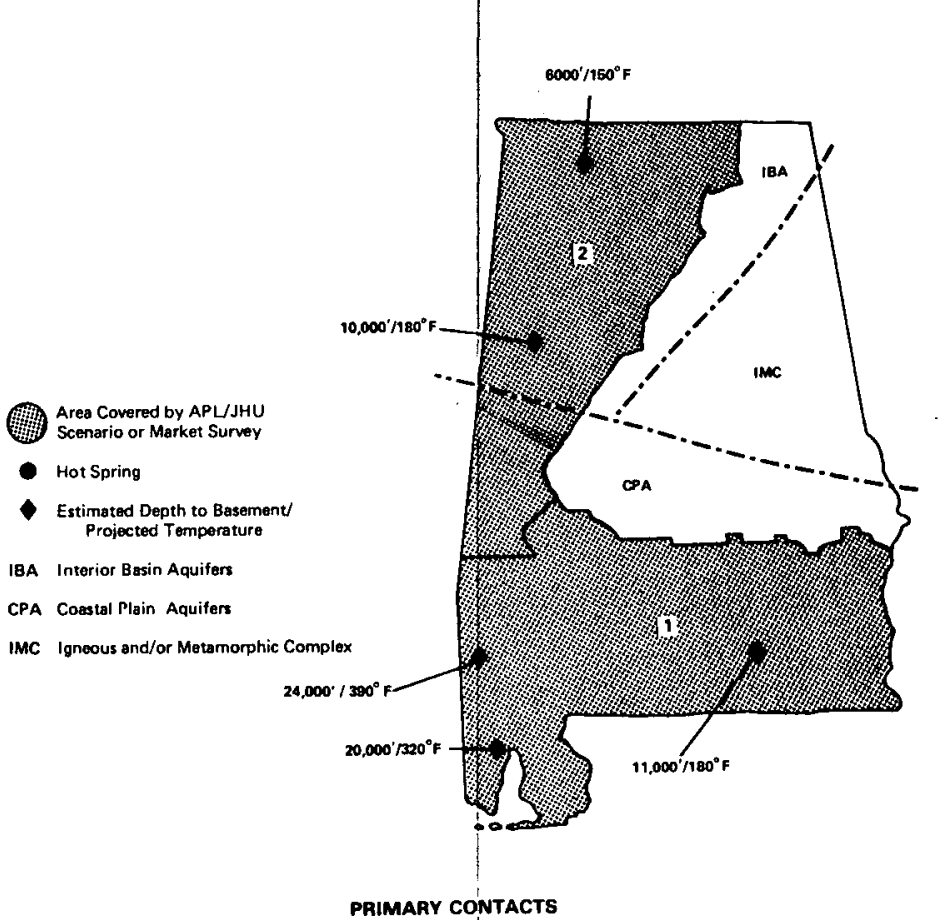

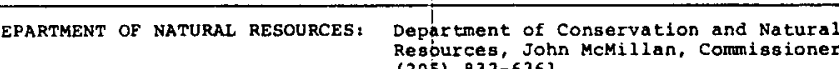

DIVISTON OF WATRR RIGHTS:

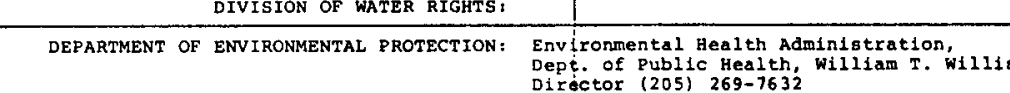

OFF ICE OF ENBRGY POLICY: A1abana Depar tment of Energy, Jack \&. Rava

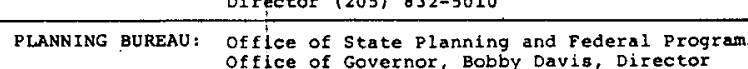

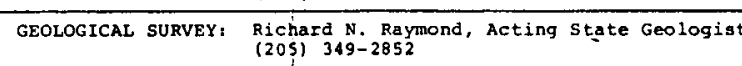

LEGILATIVE CONTACTS

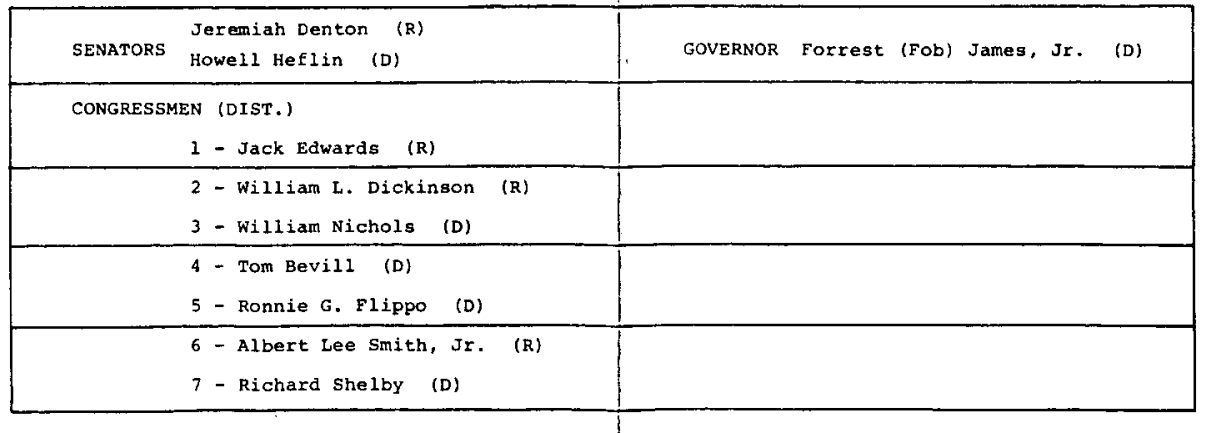



I II STATE FUEL PRODUCTION (1973) (C-6)

Type

Coal mines

Natural gas (liq.)

Natural gas wells

Crude oil. wells
Number

248

92

222

684
Units

Trillion

Btu

707

48

132

56.9

\section{GEOLOGY}

The southern half of Alabama, the Gulf Coastal Plain, consists of a southwest thickening wedge of unconsolidated Mesozoic and Cenozoic sediments that attain thicknesses in excess of 20,000 ft. near the coast.

In the west-central part of the state, these sediments overlie Paleozoic sedimentary rocks that are exposed to the north in the Black Warrior Basin (beneath the Allegheny Plateau and the Valley and Ridge Province). Throughout most of the south Alabama area, however, these sediments are underlain by Paleozoic and PreCambrian crystalline rocks, which are represented in outcrop by the metamorphic and igneous complex of the piedmont area in the east in the east-central part of the state.

Although several warm springs do occur in the crystalline Piedmont rocks, the most attractive resource areas lie within the sedimentary basins. Geopressured reservoirs may exist in the deeper parts of the coastal plain adjacent to the Mississippi Interior Salt Dome Basin. Hydrothermal resources probably occur in both the Black Warrior Basin and the coastal plains. The main restraint on development is the depth needed to obtain usefully hot water, and to locate reservoirs with easily extractable water. Geothermal gradients above $1.6^{\circ} \mathrm{F} / 100$ ft. occur locally in both basin areas.

V.

\section{RESOURCE DATA}

Water availability is likely to be greater in the unconsolidated sediments of the Gulf Coastal Plain; however, several horizons in the Black Warrior Basin are highly permeable. Where $10,000 \mathrm{ft}$. of sediments exist, temperatures are likely to be at least $180^{\circ} \mathrm{F}$. In the deeper areas, where sediments are $20,000 \mathrm{ft}$. thick, temperatures may be near $325^{\circ} \mathrm{F}$. Exploration should aim to areas of higher heat flow.

The Tuscaloosa Sandstone Formation seems to be anomalously warm at depths of about 3,000 ft. near Cottonwood and Dothan, and produces waters of $122^{\circ} \mathrm{F}$ and $104^{\circ} \mathrm{F}$, respectively. 
THE JOHNS HOPKINS UNIVERSITY

APPLIED PHYSICS LABORATORY

LAUREL, MARYLAND

1. BLACK WARRIOR BASIN

Type aquifer: Paleozoic clastic sediments Area: $17,000 \mathrm{sq}$. mi. Depth: 6,000 to 10,000 ft. Avg. thickness:

Porosity:

Water temperature: $150^{\circ}$ to $212^{\circ} \mathrm{F}$

Recharge rate:
Estimate of water stored in aquifer: $8 \times 10^{13} \mathrm{cu}$. ft.

Estimate of energy content in water: $300 \times 10^{15} \mathrm{Btu}^{\dagger}$

2. SOUTHERN ALABAMA

Type aquifer: clastic sediments Area: 17,600 sq. mi. Depth: in excess of $20,000 \mathrm{ft}$. Avg. thickness:

Porosity: Transmissivity:

Water temperature: Over $350^{\circ} \mathrm{F}$

Recharge rate:

Estimate of water stored in aquifer: $2 \times 10^{14} \mathrm{cu}$. ft.

Estimate of energy content in water: Over $1,000 \times 10^{15} \mathrm{Btu}^{\dagger}$

$\dagger_{\text {Above }} 120^{\circ} \mathrm{F}$, reference to $90^{\circ} \mathrm{F}$; $10 \%$ porosity assumed, about 4.5 times this amount in rock.

VI. GEOTHERMAL ACTIVITY

Current uses:

Hot Springs (flowing deep well) at Cottonwood and Dothan used for balneological purposes.

Recent studies: Alabama Geologic Survey "Assessment of the Geothermal/Geopressure Potential of the Gulf Coastal Plain of Alabama."

DOE/DGE State Coupled Resource Assessment Program.

VII. LEGAL ACTIVITIES

Proposals of a Geothermal Resources Act have been considered by State Legislature. No act has been passed to date.

\section{CONTACTS}

1. Geological Survey of Alabama, P.O. Drawer 0, University, AL 35486, Richard N. Raymond, State Geologist, (205) $349-2852$. 
2. Alabama Department of Energy, 25 Washington Avenue, Montgomery, AL 36130, Jack Ravan, Director, (205) $832-5010$.

3. State Planning Office, Alabama Developrent Office, State Capitol, Montgomery, AL 36130, William Mathews, (205) 832-6400.

REFERENCES AND LIST OF SIGNIFTCANT REPORTS

(1) S. S. Papadopulos, R. H. Wallace, Jr., J. B. Wesselman, and R. E. Taylor, "Assessment of Onshore GeopressuredGeothermal Resources in the Northern Gulf of Mexico Basin," Assessment of Geothermal Resources of the United states, USGS Circular 726, 1975.

(2) R. S. Barnett, "Basement structure of Florida and Its Tectonic Implications," Transactions of the Gulf Coast Association of Geological Societies, Vol. XXV, pp. 122139,1975 .

(3) G. V. Wilson, "Early Differential Subsidence and Configuration of the Northern Gulf Coast Basin in Southwest Alabama and Northwestern Florida," Transactions of the Gulf Coast Association of Geological Societies, Vol. XXV, pp. 196-206, 1975.

(4) 1976 Alabama Directory of Mining and Manufacturing, Alabama Development Office, 1976.

(5) "Assessment of the Geothermal/Geopressure Potential of the Gulf Coastal Plain of Alabama," A Progress Report: Technical Information Interchange Meeting Minutes, QM79-261, Dec 1979.

COMMON REFERENCES

$(C-1),(C-2),(C-3),(C-4),(C-5),(C-6)$, and $(C-7)$. 


\author{
FACT SHEETS RELATING TO USE OF \\ GEOTHERMAL ENERGY IN THE UNITED STATES
}

\title{
INTRODUCTION
}

This report is a compilation of data relating to geothermal energy in each of the 50 states. The data are summarized on one page for each state. All summary data sheets use a common format. Following the summary data sheet there are additional data on the geology of each state pertaining to possible hydrothermal/geothermal resources. Also there is a list of some of the reports available pertaining to the state and state energy contacts. The intent of these documents is to present in a concise form reference data for planning by the Department of Energy. It is planned that this report will be revised periodically as required to keep it current. For comments, additions, or corrections, please contact Mrs. B. Klaess the Applied Physics Laboratory (301) 953-7100, extension 3039 . 
- iv- 
The following lists of contacts are given to provide users of the fact sheets with an extended source of contact and information than might otherwise be included with the material for the individual states. The user must remember that there may have. been personnel changes to the federal, state, or organizational level that would affect the accuracy of the lists of names of individuals, however, even though there may be shifts in personnel, the offices and addresses will probably remain as they are listed here.

\section{GEOTHERMAL COMMERCIALIZATION TEAMS}

\section{State Teams}

Alaska

Mr. Dan Markie

Alaska Division of Energy and Power Development Mackay Building - 7 th Floor. 338 Denali Street Anchorage, AK 99501

(907) 276-0508

\section{Arizona}

Dr. Don White

Dept. of Chemical Engineering

University of Arizona

Tucson, AZ 85721

(602) $626-1224 / 5$

California

Neil Moyer

Director of Geothermal office California Energy Commission 1111 Howe Avenue Sacramento, CA 95825 (916) $920-6025$

\section{Colorado}

Richard Pearl

Colorado Geological Survey

1313 Sherman St., Room 715

Denver, CO 80203

(303) 839-2611

Delaware

Dan Anstine

State Energy office

P. O. Box 1401

Dover, Delaware 19901

(302) 736-5697

Hawaii

James Woodruff

Dept. of Planning and Economic Development

P. O. Box 2359

Honolulu, HI 96804

(808) 548-4195 
Idaho

Alex Sifford, Deputy Director Office of Energy

Statehouse

Boise, ID 83720

(208) 334-3788

Montana

Jeff Birkby

Montana Department of Natural

Resources and Conservation

32 South Ewing

Helena, MT 59601

(404) 449-4600

Nevada

Noel Clark, Director

Nevada Department of Energy

1050 East Williams, Suite 405

Carson City, NV 89710

(702) 885-5157

New Mexico

George Scudella

New Mexico Energy \& Mineral Dept.

P. O. Box 2770

Santa $\mathrm{Fe}, \mathrm{NM} 87501$

(505) $827-2472$

North Dakota

Bruce Gaugler

Energy Management \& Conservation Washington

Governor's Office

1533 N. 12th st.

Bismarck, ND 58505

(701) 224-3144
Oregon

Dave Philbrick

Oregon Department of Energy

102 Labor and Industry Bidg.

Salem, OR 97310

(503) $378-5584$

South Dakota

Phil Iidel

office of Energy Policy

Capitol Lake Plaza

Pierre, SD 57501

(605) 773-3603

$\underline{\text { Utah }}$

Stanley Green, Director

Utah Department of Natural

Resources

Division of Water Rights

200 Empire Building

231 East 400 South

Salt Lake City, UT 84111

(801) 553-6071

\section{Virginia}

Dr. Robert C. Malici

State Geologist and Commissioner

Division of Mineral Resources

Natural Resource Building

P.O. Box 3667

Charlottesville, VA 22903

(804) 293-512i
Gordon Bloomquist

Washington State Energy office

$400 \mathrm{E}$. Union Street

Olympia, WA 98504

(206) 754-0774 
State Teams (cont'd)

Wyoming

Rick James

C/O RMIEE - Box 3965

University Station

Laramie, WY 82071

(307) 766-6760

\section{County Teams}

Dave Pierson, Director

Public Works Department

Imperial County

The Courthouse

El Centro, CA 92243

\section{$\underline{\text { Regional Teams }}$}

Fletcher C. Paddison

The Johns Hopkins University

Applied Physics Laboratory

Johns Hopkins Road

Laure1, MD 20810

E. G. DiBello

$\mathrm{EG} \& \mathrm{G}$, Inc.

P. O. Box 1625

Idaho Falls, ID 83415

Roy A. Cunniff

New Mexico Energy Institute

New Mexico state University

P. O. Box $3 \mathrm{EI}$

Las Cruces, NM 88003

DOE REGIONAL OFFICES

Region I

Harold J. Keohane

Regional Representative

Analex Building, Room 700

150 Causeway street

Boston, MA 02114

(617) 223-3701
Robert Van Horn, Executive

Director

GRIPS Commission

2628 Mendocino Avenue

Santa Rosa, CA 95401

Paul J. Lienau

Geo-Heat Utilization Center

Oregon Institute of Technology

Klamath Falls, OR 97601

Phillip M. Wright

Earth Science Lab/UURI

420 Chipeta Way, Suite 120

Salt Lake City, UT 84108

Dr. Richard T. Meyer, President Western Energy Planners, Ltd. $2180 \mathrm{~S}$. Ivanhoe, suite 4

Denver, CO 80222

$\underline{\text { Region II }}$

Robert A. Low

Regional Representative

26 Federal Plaza

Room 3206

New York, NY 10007

(212) 264-1021 
DOE REGIONAL OFFICES (cont'd)

\section{Region III}

Ovra S. Kernodle

Regional Representative 1421 Cherry Street

Room 1001

Philadelphia, PA 19102

(215) 597-3890

Region V

Robert H. Bauer

Regional Representative 175 West Jackson Blvd.

Room A-333

Chicago, II 60604

(312) 353-0540

Region VII

Mary O'Halloran

Regional Representative 12 Grand Building.

P. O. Box 2208

112 East 12 th Street

Kansas City, MO 64142

(816) 374-2061

Region IX

William Arntz

Regional Representative 333 Market Street

San Francisco, CA 94105

(415) 764-7084

William C. Gough

George Ember

John Crawford
Region IV

Louis F. Centofanti

Regional Representative

1655 Peachtree Street, N.E.

8 th Floor

Atlanta, GA 30309

William Rankin

(404) $881 \div 2837$

Region VI

G. Dan Rambo

Regional Representative

P. O. Box 35228

2626 West Mockingbirg Lane

Dallas, $\mathrm{TX} 75235$

(214) $767-7741$

Region VIII

Dr. Charles F. Metzger

Regional Representative

P. O. Box 26247 - Belmar Branch

1975 South Yukon Street

Lakewood, $\mathrm{CO} 80226$

(303) 234-2420

Region X

Jack B. Robertson

Regional Representative

1992 Federal Building

9.15 Second Avenue

Seattle, WA 98174

(206) $442-7280$

Bob Hackman

Rowald Bendixen 
DOE OPERATIONS OFFICES

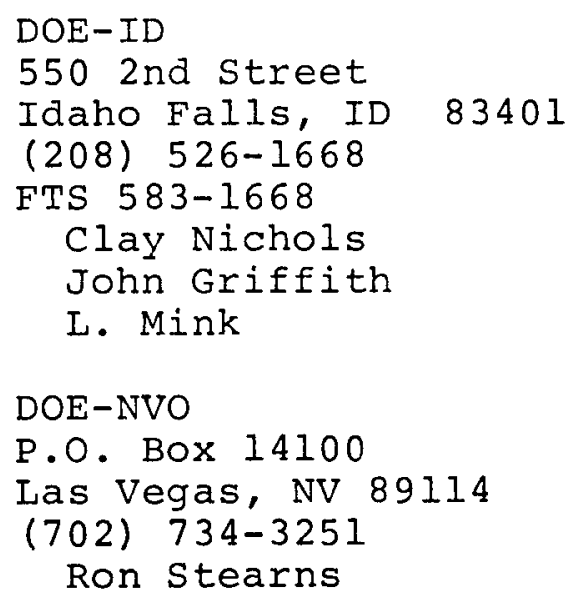

OTHER GOVERNMENT OFFICES

Director

U.S. Forest Service

P. O. Box 2417

Washington, D.C. 20013

(703) 235-8010

Bureau of Land Management 2800 Cottage Way

Sacramento, CA 95825

Jack Lahr

U.S.G.S. Conservation Division

Office of the Area Geothermal

Supervisor

2465 East Bayshore Road

Suite 400

Palo Alto, CA 94303

(415) 323-8111

FTS 467-2884

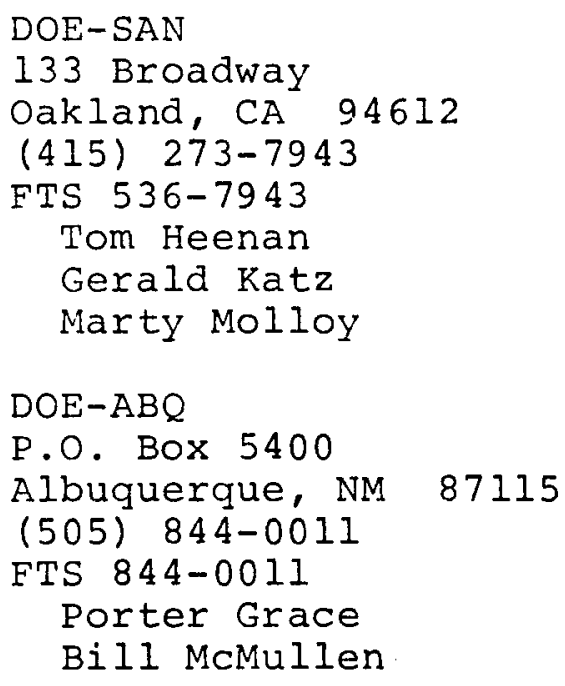

Director

National Park Service Department of the Interior 18 th and C. Street, N.W. Washington, D.C. 20240

Commissioner

Water Power Resources Service Department of the Interior 18 th and C. St., N.W. Washington, D.C. 20240

U.S. Geological Survey Office of Resource Analysis 345 Middlefield Road - MS 84 Menlo Park, CA 94025

(415) 323-8111 Wendall Duffield Marshall Reed

Bruce Blakely 
Forest Service Regions

Northern Region (R-I)

Charles T. Coston

Federal Building

Missoula, MT 59807

(406) 329-3518

FTS 585-3518

Rocky Mountain Region (R-2)

W. Rupp

11177 West 8 th Avenue

Box 25127

Lakewood, CO 80225

(303) 234-3905

FTS 234-3905
Southwest Region $(\mathrm{R}-3)$

M. Jean Hassêll

Federal Builaing

517 Gold Avenue, Sw

Albuquerque, NM 87102

(505) 766-2006

FTS 474-2006

Inter Mountain Region $(R-4)$

Jess Sirmon

$32425 \mathrm{th}$ street

Ogden, UT 84401

(801) $626-3264$

FTS $586-3264$ 


\section{Principal Contacts}

STATE

$\underline{\text { NAME }}$

Alabama

Alaska

Arizona

California

Colorado

Delaware

Gary $\mathrm{V}$. Wilson

P.O. Drawer 0

Ross G. Schaff

Donald L. Turner

845 N. Park Ave.

Tucson, AZ 85719

Roger C. Martin and Geology

Richard H. Pearl

Denver, CO 80203
Geological Survey of Alabama

University, AI 35486

Alaska Div. of Geological and Geophysical Surveys

3001 Porcupine Drive

Anchorage, AK 99501

Geophysical Institute

University of Alaska

Fairbanks, AK 99701

W. Richard Hahman, Sr.

Arizona Bureau of Geology and Mineral Technology

Geological Survey Branch

California Division of Mines

107 South Broadway, Rm 1065

Los Angeles, CA 90012

Colorado Geological survey

1313 Sherman Ave., Room 715

Ken Woodruff

Delaware Geologic Survey
(907) 479-7198

(916) 323-0967

(303) 839-2611

(302) 736-5697

PHONE NUMBER

(205) 349-2852

(907) 277-6615

\author{
(602) 884-2733
}

University of Delaware

101 Pinny Hall

Newark, DE 19711 
STATE COUPLED RESOURCE ASSESSMENT TEAMS (cont $d$ )

STATE

Hawai i

Idaho

Kansas

Montana

Nebraska

Nevada

\section{NAME}

Charles E. HelselY

Hawaii Institute of Geophysics

University of Hawaii

2525 Correa Rd.

Honolulu, HI 96822

John C. Mitchell

Department of Water Resources

450 Washington Street

Boise, ID 83702

Don W. Steeples

Kansas Geological Survey

University of Kansas

Lawrence, KS 66044

Mississippi Alvin R. Bicker

P.O. Box 5348

Jackson, MS 39216

John Sonderegger

Montana Bureau of Mines and Geology

Butte, MT 59701

William D. Gosnold

Dept. of Geography-Geology

University of Nebraska

Omaha, NE 68132

Duane A. Eversoll

Nebraska Geological survey

University of Nebraska

Lincoln, NE 68588

Dennis Trexler

Nevada Bureau of Mines and

Geology

University of Nevada

Reno, NV 89557
PHONE NUMBER

$(808): 948-8760$

(208) $334-4477$

(9.13) $864-3965$

$(601) \quad 354-6228$

(406) 792-8321

(402) $554-2457$

$(402) \quad 472-3471$

(702) $784-6691$ 
STATE COUPLED RESOURCE ASSESSMENT TEAMS (cont'd)

STATE

New Mexico

New York

North Dakota

Ohio

Oklahoma

Oregon

Texas

\section{NAME}

Chandler A. Swanberg

New Mexico State University

Physics Department

Las Cruces, NM 88001

Burton krakow

New York state Energy Research and Development

Agency Bldg. N. 2

Rockefeller Plaza

Albany, NY 12223

James R. Dunn

Dunn Geoscience

5 Northway Lane $\mathrm{N}$.

Latham, NY 12110

Kenneth I. Harris

North Dakota Geological Survey

Grand Forks, ND 58202

Frank L. Majchszak

Ohio Geological Survey

Fountain Square

Columbus, OH 43224

William F. Harrison

Oklahoma Geological Survey

University of Oklahoma

830 S. Oval

Norman, OK 73019

Donald A. Hull

Oregon Department of Geology and Mineral Industries

1069 State office Bldg.

Portland OR 97201

Charles M. Woodruff

Texas Bureau of Economic Geology University Station, Box $x$

Austin, $\mathrm{TX} 78712$
(518) 783-8102

PHONE NUMBER

(505) 646-1920

(518) 465-6251

(701) 777-2231

(614) 466-5344

(405) 325-3032

(503) 229-5580

(512) 474-5994 
STATE COUPLED RESOURCE ASSESSMENT TEAMS (CORE'd)

STATE

Texas (cont'd)

David $M$ White

Texas Energy and Natural Resources Advisory Council

411 W. 13th St., Room 800

Austin, $\mathrm{TX} 78701$

Robert F. RoY

Dept. of Geological Science

(915) 747-5501

University of Texas

El Paso, TX 79968

Utah

Virginia

Washington

Wyoming

J. Wallace Gwynn

Utah Geological and Mineral Survey 606 Black Hawk Way

Salt Lake City, UT 84108

Dr. Robert C. Malici

State Geologist and Commissioner

Division of Mineral Resources

National Resources Building

P.O. Box 3667

Charlottsville, VA 22903

J. Eric Schuster

Washington Dept. of Natural

Resources

Olympia, WA 98504

Edward R. Decker

Department of Geology

University of Wyoming

PHONE NUMBER

(512) $475-5588$

(801) $581-6831$

(804) 293-5121

(206) 753-5.327

Laramie, WY 82071

General Information

Atlantic Coastal Plain (NJ, DE, MD, VA, NC, SC, GA): John Costain (VPI\&SU) (703) 9.6l-5096

East of Mississippi River: Joel Renner (Gruy Federal) (7.03) 892-27.00

West of Mississippi River: Mike Wright (UURI) (801) 581-5283 


\section{COMMON REFERENCES}

C-1 Geothermal Gradient Map of North America. AAPG and USGC, 1976 .

C-2 Population Distribution, Urban and Rural in U.S., 1970. US Maps GE-50, No. 45, Bureau of the Census, 1970.

C-3 Heating and Cooling Degree Day Data, Environmental Information summaries, C-14, NOAA 1976.

C-4 County and City Data Book, 1972, GPO stock No. 0324-00121, U.S. Bureau of the Census, 1973.

C-5 1972 Census of Manufacturers, Vol. III, Area Statistics, U.S. Bureau of the Census, 1976.

C-6 "Fuels and Energy Data, U.S. by States and Census Divisions, 1972," U.S. Department of Interior, Bureau of Mines Information Circular, IC-8722, 1976.

C-7 Federal Energy Data System (FEDS), Statistical Summary, February 1978, DOE/EIA-0031/2, UC-13, U.S. Department of Energy.

C-8 "Geothermal Energy and The Eastern U.S., Technical Information Interchange Meeting, Minutes," APL/JHU Report QM-79-261, Dec 1979. (See C-17 for fifth meeting in this series.)

C-9 Resource Assessment/Commercialization Planning Meeting, Salt Lake City, Utah, Jan 1980, DOE:DGE/DGRM.

C-10 "Geothermal Energy and the Eastern U.S., A Scenario for Geothermal Energy Development, The Atlantic Coastal Plain," APL/JHU Report QM-77-129, Oct 1977.

C-11 "Geothermal Energy and the Eastern U.S., A Scenario for Geothermal Energy Development, The Coastal Plain in Southern Arkansas," API/JHU Report QM-77-129-1, Oct 1977.

C-12 "Geothermal Energy and the Eastern U.S., A Scenario for Geothermal Energy Development, The Madison Iimestone Aquifer in Western South Dakota," APL/JHU Report QM-.77-129-2, Nov 1977. 
C-13 "Geothermal Energy and the Eastern U.S., A Scenario for Geothermal Energy Development, The Eastern Gulf Coastal Plain," APL/JHU Report QM-77-129-3, Feb 1978.

C-14 "Geothermal Energy and the Eastern U.S., A Draft Scenario for Geothermal Energy Development, Hot Dry Rock," APL/JHU Report QM-77-129-4, Mar 1978 .

C-15 J. K. Costain, L. Glover, III, and A. K. Sinha, "Evaluation and Targeting of Geothermal Energy Resources in the Southeastern United States-Progress Report," VPI and SU 5103-1 through -7 (represents a series of reports).

C-16 J. L. Renner and Tracy L. Vaught, "Geothermal Resources of the Eastern United States," Report by Gruy Federal, Inc. " (Contract No. DE-AC08-78ET28373), DOE/NVO/1558-7, Dec 1979.

C-17 "Geothermal Energy and the Eastern U.S.; Fifth Technical Information Interchange Meeting Minutes," JHU/APL Report QM-80-185, DeC 1980 . 
ALABAMA
GEOTHERMAL DATA SUMMARY SHEET

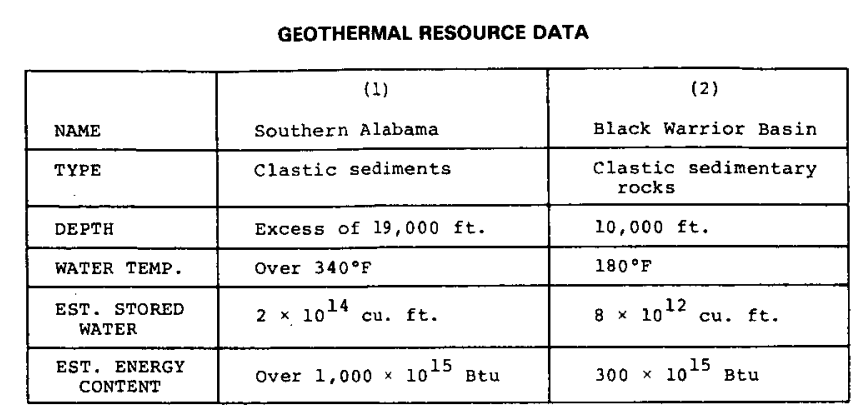

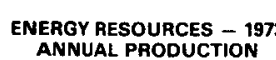

\begin{tabular}{|c|c|c|c|}
\hline TYPB & NUMBSR & starus & $10^{12} \mathrm{Btu}$ \\
\hline Coal Mines & 105 & 19,232 thousand tons & \\
\hline Natural Gas (1iq.) & & 146 thousand bb1 & 0.6 \\
\hline Natura1 Gas wel1s & 15 & $11,271 \mathrm{mi} 11$ ion cu. $\mathrm{ft}$. & 12.3 \\
\hline Crude 011 we11s & 586 & 11,677 thousand bb1 & 67.7 \\
\hline
\end{tabular}

ENERGY USE - 1975 (10": BTU)

\begin{tabular}{|c|c|c|c|c|c|}
\hline secror & OIL & DPG & GAS & COAL & $\begin{array}{l}\text { ELECr } \\
\text { purCer }\end{array}$ \\
\hline Gross & 420.4 & 20.9 & 286.4 & 683.9 & 142.0 \\
\hline RESIDENI IAI & 6.6 & 16.6 & 54.0 & 0.2 & 47.6 \\
\hline CoMMBRCIAL & 29.2 & 1.9 & 34.5 & 0.1 & 22.3 \\
\hline INDOSTRRIAL & 38.2 & 2.3 & 174.4 & 59.8 & 72.1 \\
\hline PERCENT & 30 & 1 & 20 & 48 & \\
\hline
\end{tabular}

GEOTHERMAL ACTIVITIES

\begin{tabular}{|c|c|}
\hline CURRENY USBS & 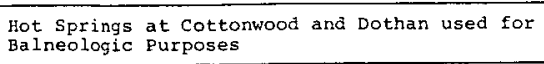 \\
\hline $\begin{array}{l}\text { RECERT OR CURRENT } \\
\text { STUDISS }\end{array}$ & 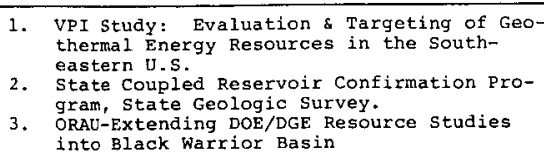 \\
\hline PROPOSED ST & \\
\hline 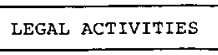 & \\
\hline
\end{tabular}

TORAL POOULARTON: $3,444,165$ TOOAL AREA: 50,708 SQ. MI

GEOTHERMAL OVERVIEW Thick sedimentary cover in the southern and western por
tions of the state contain shallow hydrothermal aquifers 1.e.e., Tuscaloosa formationn due to higher than normal State Geologic Survey. Dotata on geepressured regions i
the southern portion of the state are available.
T. The

- Hot Spring

- Estimated Deph ro Bassement

IBA Interior Basin Aquiters

IMC Igneous andor Metamorphic Complex
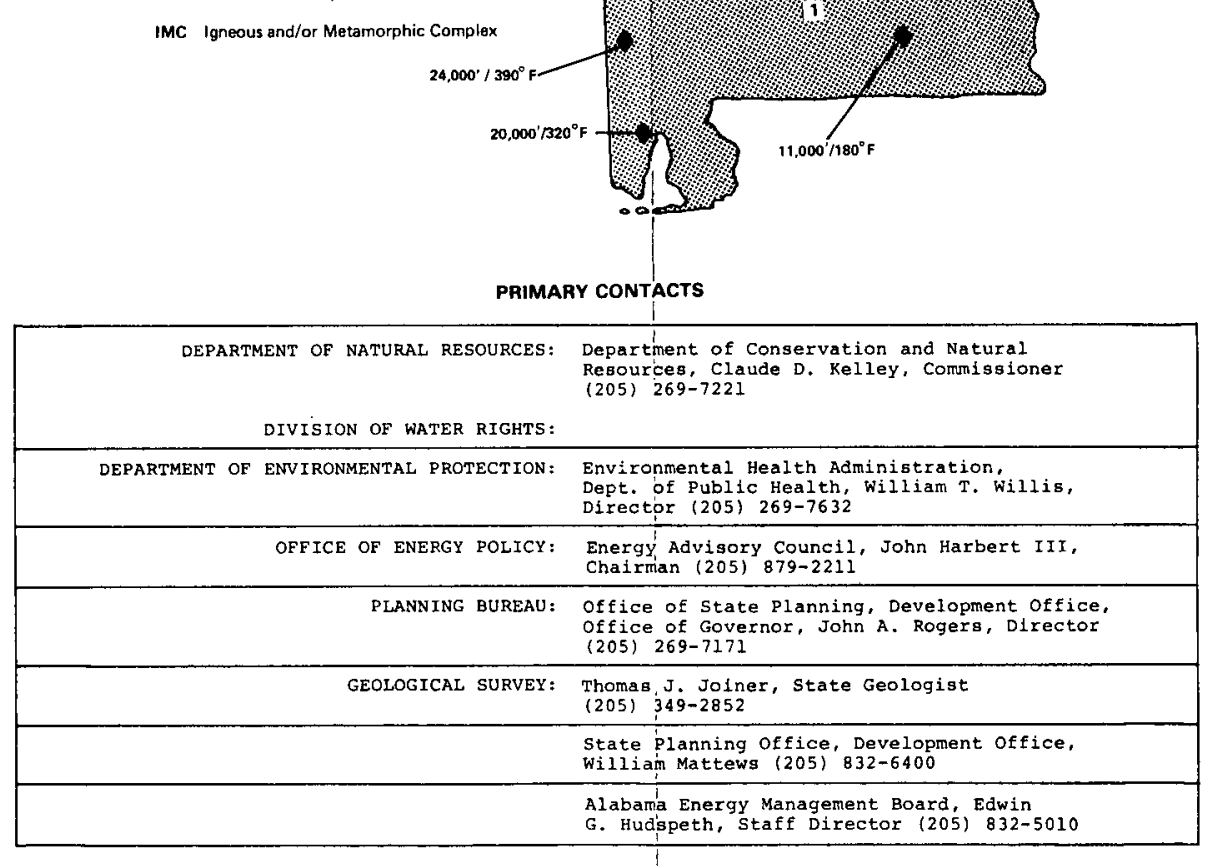

\begin{tabular}{|c|c|}
\hline 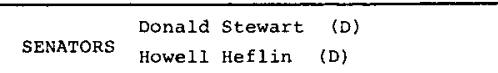 & GOVERNOR Forrest (Fob) Janes, Jr. (D) \\
\hline $\begin{array}{l}\text { CONGRESSMEN (DIST.) } \\
1 \text { - Jack Edwards (R) }\end{array}$ & \\
\hline 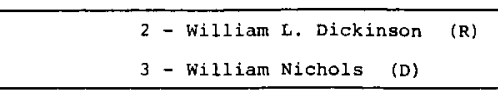 & \\
\hline $\begin{array}{l}4-\text { Tom Bevi11 (D) } \\
5 \text { - Ronnie G. Filppo (D) }\end{array}$ & \\
\hline $\begin{array}{l}6 \text { - Albert Lee Smith, } J x \text { (R) } \\
7 \text { - Richard Shelby (D) }\end{array}$ & \\
\hline
\end{tabular}


State Geothermal Fact sheet

ALABAMA

I. DEMOGRAPHIC INFORMATION (1970) (C-4)

TOTAL STATE

Population: $3,444,165$ Area: 50,708 sq. mi. Density: 68 per sq. mi.

GEOTHERMAL RESOURCE AREA

Population: 2,460,000 Area: 35,000 sq. mi. Density: 71 per sq. mi.

II. ENERGY CONSUMPTION* (1975) (C-7)

\begin{tabular}{cccccc}
\hline & $\begin{array}{c}\text { OIL } \\
\text { (million } \\
\text { bbl) }\end{array}$ & $\begin{array}{c}\text { LPG } \\
\text { (million } \\
\text { gal.) }\end{array}$ & $\begin{array}{c}\text { GAS } \\
\text { (trillion } \\
\text { cu.ft.) }\end{array}$ & $\begin{array}{c}\text { COAL } \\
\text { (million } \\
\text { tons) }\end{array}$ & $\begin{array}{c}\text { ELECTRICITY } \\
\text { PURCHASED } \\
\text { (billion kWh) }\end{array}$ \\
GRoSS & 76 & 219 & 278 & 28 & 42 \\
Residential & 1 & 174 & 52 & 0.01 & 14 \\
Commerical & 5 & 19 & 33 & 0.00 & 7 \\
Industrial & 6 & 24 & 169 & 2 & 21
\end{tabular}

Trillion Btu

\begin{tabular}{|c|c|c|c|c|c|}
\hline $\begin{array}{l}\text { GROSS } \\
\text { Residential } \\
\text { Commercial } \\
\text { Industrial }\end{array}$ & $\begin{array}{r}420.4 \\
6.6 \\
29.2 \\
38.2\end{array}$ & $\begin{array}{r}20.9 \\
16.6 \\
1.9 \\
2.3\end{array}$ & $\begin{array}{r}286.4 \\
54.0 \\
34.5 \\
174.4\end{array}$ & $\begin{array}{r}683.9 \\
0.2 \\
0.1 \\
59.8\end{array}$ & $\begin{array}{r}142.0 \\
47.6 \\
22.3 \\
72.1\end{array}$ \\
\hline
\end{tabular}

Percentages

30

1

20

48

*Excluding nuclear and hydro electricity, coking coal and petroleum coke, and other petroleum products not used as fuels. 
III. STATE FUEL PRODUCTION (1973) $(C-6)$

Type Number Units $\begin{gathered}\text { Trillio } \\ \text { Btu }\end{gathered}$

Coal mines

Natural gas (liq.)

Natural gas welis

Crude oil wells
105

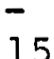

15

586
19,232 thousand tons

146 thousand bbl

11,271 million cu. ft.

11,677 thousand bbl
49.5

0.6

12.3

67.7

IV. $\quad$ GEOLOGY

The southern half of Alabama, the Gulf Coastal Plain, consists of a southwest thickening wedge of unconsolidated Mesozoic and Cenozoic sediments that attain thicknesses in excess of 20,000 ft. near the coast.

These sediments overlie Paleozoic sedimentary rocks that are exposed in the northern part of the state in the Black Warrior Basin (beneath the Allegheny Plateau and the Valley and Ridge Province). Along the eastern border of the state, the Precambrian and Paleozoic crystalline basement rocks of the Piedmont and Blue Ridge are exposed, and Paleozoic and Pre-Cambrian metamorphic and igneous rocks are exposed in the east-central part of the state.

Although several warm springs do occur in the crystalline piedmont rocks, the most attractive resource areas lie within the sedimentary basins. Geopressured reservoirs may exist in the deeper parts of the coastal plain adjacent to the Mississippi Interior salt Dome Basin. Hydrothermal resources probably occur in both the Black Warrior Basin and the coastal plains. The main restraint on development is the depth needed to obtain usefully hot water, and to locate reservoirs with easily extractable water. Geothermal gradients above $1.6^{\circ} \mathrm{F} / 100 \mathrm{ft}$. occur locally in both basin areas.

$\mathrm{V}$.

RESOURCE DATA

Water availability is likely to be greater in the unconsolidated sediments of the Gulf Coastal Plain; however, several horizons in the Black Warrior Basin are highly permeable. Where $10,000 \mathrm{ft}$. of sediments exist, temperatures are likely to be at least $180^{\circ} \mathrm{F}$. In the deeper areas, where sediments are 20,000 ft. thick, temperatures may be near $325^{\circ} \mathrm{F}$. Exploration should aim to areas of higher heat flow.

The Tuscaloosa Sandstone Formation seems to be anomalously warm at depths of about 3,000 ft. near Cottonwood and Dothan, and produces waters of $122^{\circ} \mathrm{F}$ and $104^{\circ} \mathrm{F}$, respectively. 
1. BLACK WARRIOR BASIN

Type aquifer: Paleozoic clastic sediments Area: 17,000 sq. mi. Depth: 6,000 to $10,000 \mathrm{ft}$. Avg. thickness:

Porosity:

Transmissivity:

Water temperature: $150^{\circ}$ to $212^{\circ} \mathrm{F}$

Recharge rate:

Estimate of water stored in aquifer: $8 \times 10^{13} \mathrm{cu}$. ft.

Estimate of energy content in water: $300 \times 10^{15} \mathrm{Btu}^{\dagger}$

2. SOUTHERN ALABAMA

Type aquifer: clastic sediments Area: 17,600 sq. mi. Depth: in excess of $20,000 \mathrm{ft}$. Avg. thickness:

Porosity:

Water temperature: Over $350^{\circ} \mathrm{F}$

Recharge rate:

Estimate of water stored in aquifer: $2 \times 10^{14} \mathrm{cu}$. ft.

Estimate of energy content in water: Over $1,000 \times 10^{15} \mathrm{Btu}^{\dagger}$

${ }^{\dagger}$ Above $120^{\circ} \mathrm{F}$, references to $90^{\circ} \mathrm{F} ; 10 \%$ porosity assumed, about 4.5 times this amount in rock.

VI. GEOTHERMAL ACTIVITY

Current uses:

Hot Springs at Cottonwood and Dothan used for balneological purposes.

Recent studies: Alabama Geologic Survey "Assessment of the Geothermal/Geopressure potential of the Gulf Coastal Plain of Alabama."

DOE/DGE State Coupled Resource Assessment Program.

VII. LEGAL ACTIVITIES

Proposals of a Geothermal Resources Act have been considered by state Legislature. No act has been passed to date.

VIII. CONTACTS

1. Geological Survey of Alabama, P.O. Drawer O, University, AL 35486, Thomas J. Joiner, State Geologist, (205) $349-2852$. 
2. Alabama Energy Management Board, c/o Alabama Development office, State Capitol, Montgomery, AL 36130 , Edwin G. Hudspeth, Staff Director, (205) 832-5010.

3. State Planning Office, Alabama Development Office, State Capitol, Montgomery, AL 36130, William Mathews, (205) 832-6400.

\section{REFERENCES AND LIST OF SIGNIFICANT REPORTS}

(1) S. S. Papadopulos, R. H. Wallace, Jr., J. B. Wesselman, and R. E. Taylor, "Assessment of Onshore GeopressuredGeothermal Resources in the Northern Gulf of Mexico Basin," Assessment of Geothermal Resources of the United states, USGS Circular 726, 1975 .

(2) R. S. Barnett, "Basement Structure of Florida and Its Tectonic Implications," Transactions of the Gulf coast Association of Geological societies, Vol. XXV, pp. 122139,1975 .

(3) G. V. Wilson, "Early Differential subsidence and Conm figuration of the Northern Gulf Coast Basin in Southeast Alabama and Northwestern Florida," Transactions of the Gulf Coast Association of Geological Societies, Vol. XXV, pp. 196-206, 1975.

(4) 1976 Alabama Directory of Mining and Manufacturing, Alabama Development office, 1976.

(5) "Assessment of the Geothermal/Geopressure Potential of the Gulf Coastal Plain of Alabama," A Progress Report: Technical Information Interchange Meeting Minutes, $Q M$ 79-261, Dec 1979.

COMMON REFERENCES

$$
(c-1),(c-2),(c-3),(c-4),(c-5),(c-6), \text { and }(c-7) .
$$


GEOTHERMAL DATA SUMMARY SHEET

ENERGY RESOURCES - 1973
ANNUAL PROOUCCTON

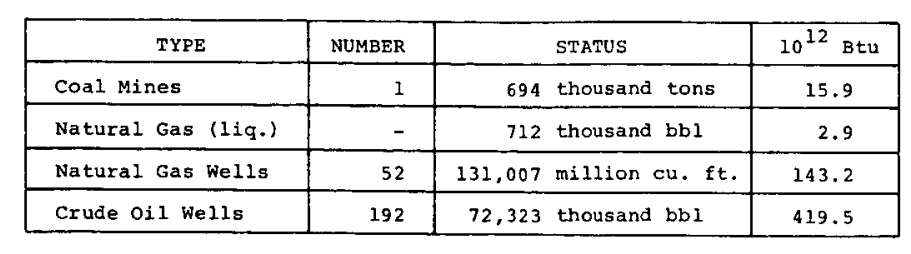

ENERQY USE - 1975 (10" BTU

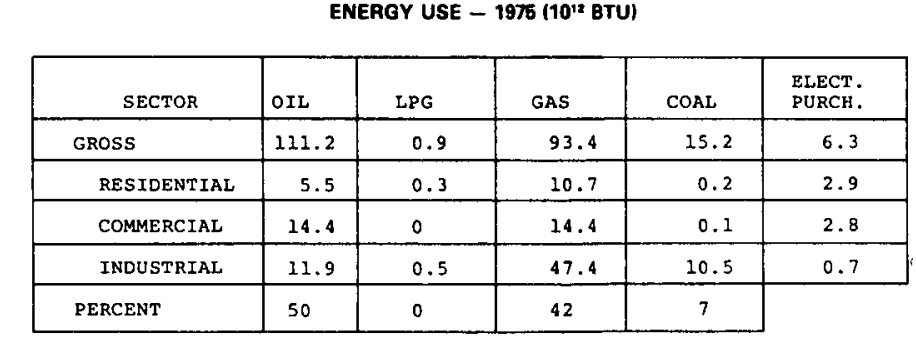

GEOTHERMAL ACTIVITIE

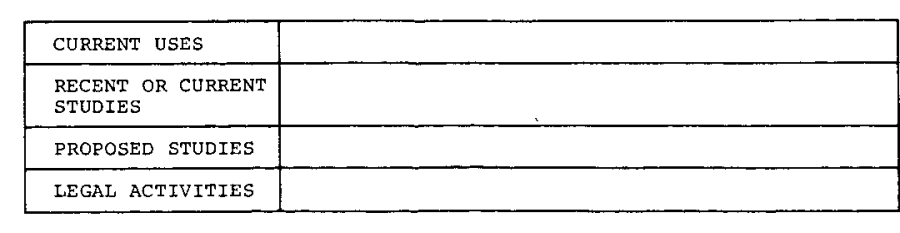

TOTAL POPULATTIN: 300,382 TOTAL AREA: 566,432 5Q. MI.

FOPULATION DENSTTY: $\quad 1.0$ PERSONS/SQ. MI.

GEOTHERMAL OVERVIEW

Hot water hydrothermal convection systems with temperalures above emperature systems $190^{\circ} \mathrm{C}$ to $1500 \mathrm{C}$ ) are common in the easi-west trending Brooks Range north of Fairbanks and near sy high he Bay and Anchor age, although data are sparse.

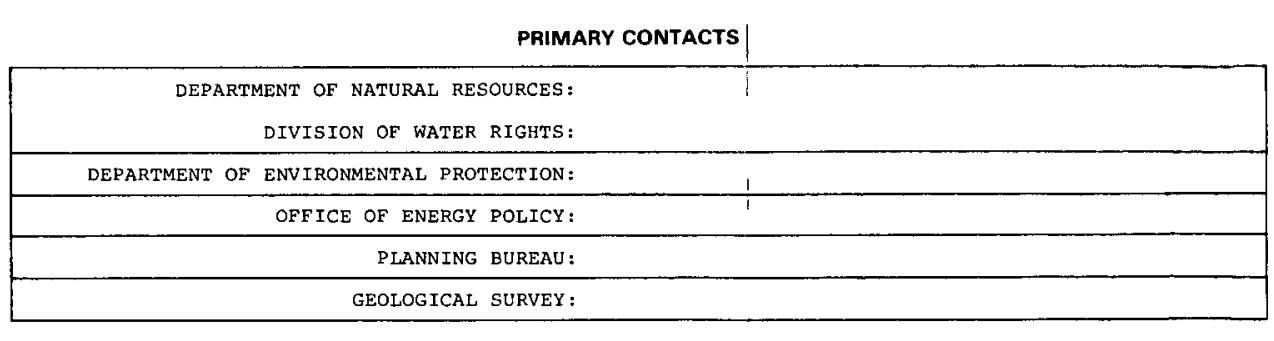

LEGISLATIVE CONTACTS

\begin{tabular}{|c|c|}
\hline 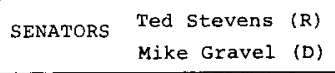 & GOVERNOR Jay S. Hammond (R) \\
\hline $\begin{array}{l}\text { CONGRESSMAN (DIST.) } \\
\text { Don Young (R) }\end{array}$ & \\
\hline
\end{tabular}


State Geothermal Fact Sheet

ALASKA

I. DEMOGRAPHIC INFORMATION (1970) (C-4)

TOTAL STATE

Population: 300,382 Area: $566,432 \mathrm{sq} \cdot \mathrm{mi}$. Density: 1 per sq. mi.

GEOTHERMAL RESOURCE AREA

Population:

Area :

sq. mi.

Density:

per sq. mi.

II. ENERGY CONSUMPTION*

(1975) (C-7)

OIL IPG

PG

(million (million
bbl) gal.)
GAS
(trillion
cu.ft.)
COAL
(million

tons)

ELECTRICITY

PURCHASED

点
GROSS
Residential
Commerical
Industrial

20

1

2

90
10
15
46

1
0
0
0.5

$$
\begin{aligned}
& 2 \\
& 1 \\
& 1
\end{aligned}
$$$$
\begin{array}{ll}
0 & 15 \\
6 & 46
\end{array}
$$

\begin{tabular}{|c|c|c|c|c|c|}
\hline $\begin{array}{l}\text { GROSS } \\
\text { Residential } \\
\text { Commercial } \\
\text { Industrial }\end{array}$ & $\begin{array}{r}111.2 \\
5.5 \\
14.4 \\
11.9\end{array}$ & $\begin{array}{l}0.9 \\
0.3 \\
0 \\
0.5\end{array}$ & $\begin{array}{l}93.4 \\
10.7 \\
14.4 \\
17.4\end{array}$ & $\begin{array}{r}15.2 \\
0.2 \\
0.1 \\
10.5\end{array}$ & $\begin{array}{l}6.3 \\
2.9 \\
2.8 \\
0.7\end{array}$ \\
\hline Percentages & 50 & 0 & 42 & 7 & \\
\hline
\end{tabular}

Trillion Btu

\footnotetext{
petroleum products not used as fuels.
} 
III. STATE FUEL PRODUCTION (1977) (C-6)

Type Number

Coal mines

Natural gas (liq.)

Natural gas wells

Crude oil wells

$\begin{array}{rr}1 & 694 \text { thousand tons } \\ - & 712 \text { thousand bbl } \\ 52 & 131,007 \text { million cu. ft. } \\ 192 & 72,323 \text { thousand bbl }\end{array}$

Units

Trition

Btu

15.9

2.9

143.2

419.5

IV. GEOLOGY

Hot water hydrothermal convection systems with temperatures above $150^{\circ} \mathrm{C}$ are known to occur on Umnak Island and near Ketchikan on the Juneau Peninsula. Lower temperature systems $\left(90^{\circ} \mathrm{C}\right.$ to $\left.150^{\circ} \mathrm{C}\right)$ are common in the east-west trending Brooks Range north of Fairbanks and near Sitka on the Juneau Peninsula. Areas of anomalously high geothermal gradient occur near Prudhoe Bay and Anchorage, although data are sparse.

V. RESOURCE DATA

To be determined.

VI. GEOTHERMAL ACTIVITY

To be determined.

VII. LEGAL ACTIVITIES

To be determined.

VIII. CONTACTS

None at present.

REFERENCES AND LIST OF SIGNIFICANT REPORTS

(1) Donald Markle, "Geothermal Energy in Alaska: Site Data Base and Development Status," Geo-Heat Utilization Center, Klamath Falls, OR, Apr 1979.

COMMON REFERENCES

$(C-4),(C-6)$, and $(C-7)$. 
ENERGY RESOUACES - 1973
ANNUAL PROOUCTON

\begin{tabular}{|c|c|c|c|}
\hline TYPE & NOMBER & starus & $10^{12} \mathrm{Btu}$ \\
\hline Coal Mines & 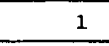 & 3,242 thousana tons & 70.9 \\
\hline Natural Gas (1iq.) & & 0 thousand $1, b 1$ & 0 \\
\hline Natura1 Gas we118 & 4 & $125 \mathrm{millition} \mathrm{cu}$. $\mathrm{ft}$. & 0.1 \\
\hline Crude oil we11s & 28 & 804 thousand bb1 & 4.7 \\
\hline
\end{tabular}

EṆERGY USE - 1976 (10' BTU)

\begin{tabular}{|c|c|c|c|c|c|}
\hline SECTOR & OIS & LPG & GAS & COAL & $\begin{array}{l}\text { ELEECT. } \\
\text { PURCH: }\end{array}$ \\
\hline GRoss & 286.2 & 4.5 & 159.3 & 86.0 & 69.3 \\
\hline RESIDENTIAL & 2.1 & 2.3 & 39.1 & 0 & 24.7 \\
\hline COMMERCIAI & 4.5 & 0.3 & 33.1 & 0 & 26.0 \\
\hline INDUSTRTAL & 21.9 & 1.9 & 50.5 & 2.9 & 19.5 \\
\hline $\begin{array}{l}\text { PERCENT } \\
\end{array}$ & 53 & 1 & 30 & 16 & \\
\hline
\end{tabular}

GEOTHERMAL ACTIVITIES

\begin{tabular}{|c|c|}
\hline $\begin{array}{ll}\text { CURBENT USES } \\
\text { S }\end{array}$ & Water use for balneologic purposes \\
\hline $\begin{array}{l}\text { RECENT OR CURRENT } \\
\text { STUDIES }\end{array}$ & 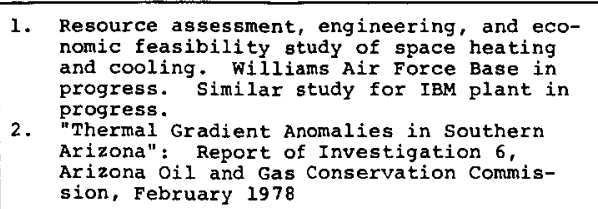 \\
\hline PROPOSED STUDIES & $\begin{array}{l}\text { Preparation of Site Specific and Area Develop- } \\
\text { ment prans }\end{array}$ \\
\hline LEGAL ACTIVIYIIES & 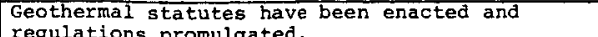 \\
\hline
\end{tabular}

GEOTHERMAL DATA SUMMARY SHEET (cf. state Geothermal Fact sheet, Arizona)

TORAL POPULATION: 2, 266,789 TOTAL AREA: 113,909 SQ. MI. POPULATTON DENSTTY: 19.9 PRRSONS/SQ. MI.

GEOTHERMAL OVERVIEW

Thirty-seven moder ate temperature reservoirs have been confirmed in eight southern and western counties in the
Basin and Range geologic province. Deep circultion is Basin and Range geologic province. Deep circulation is
expected in the many range--front and basin faults. Areas
of recent volcanism in the colorado Plateau province are considered to have potentid.

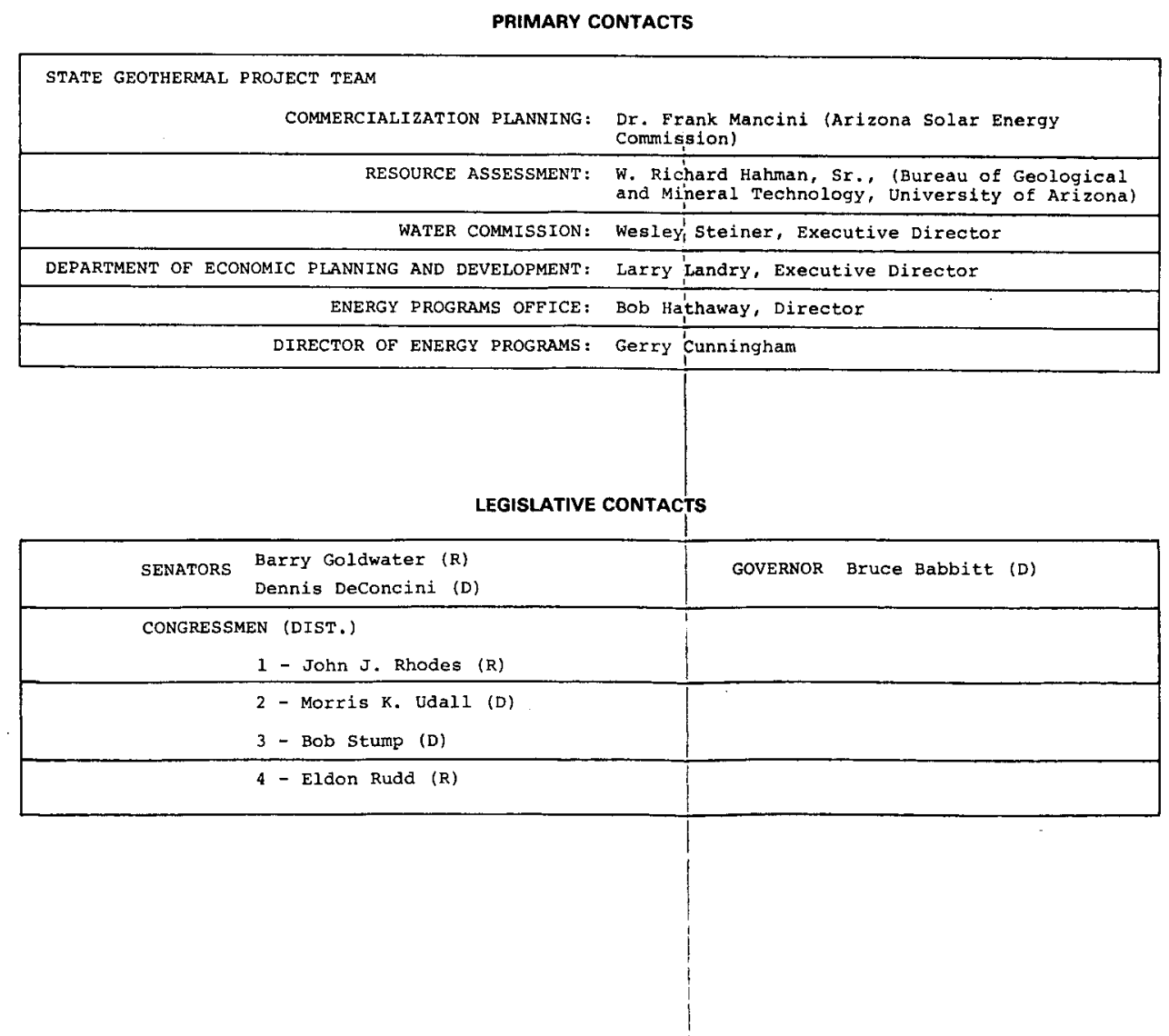


State Geothermal Fact Sheet

ARIZONA

I. DEMOGRAPHIC INFORMATION (1976) (C-4)

TOTAL STATE

Population: 2,266,789 Area: 113,909 sq. mi. Density:19.9 per sq. mi.

GEOTHERMAL RESOURCE AREA

Population: Area: sq. mi. Density: per sq. mi.

II. ENERGY CONSUMPTION ${ }^{*}$ (1975) (C-7)

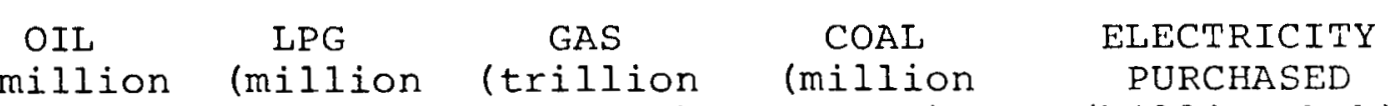

$\begin{array}{ll}\$ & \text { GROSS } \\ 1 & \text { Residential } \\ & \text { Commerical } \\ & \text { Industrial }\end{array}$

bbl)

gal.)

cu.ft.)

tons)

(billion k.Wh)

52

0

4

47

24

3
19

154

38

33

49

4
0
0
0

20
7
8
6

Trillion Btu

GROSS
Residential
Commercial
Industrial

Percentages

$$
\begin{array}{r}
286.2 \\
2.1 \\
4.5 \\
21.9
\end{array}
$$

53

$\begin{array}{rr}4.5 & 159.3 \\ 2.3 & 39.1 \\ 0.3 & 33.7 \\ 1.9 & 50.5 \\ & \\ 1 & 30\end{array}$

86.0

69.3

24.7

26.0

0

2.9

19.5

16

*Excluding nuclear and hydro electricity, coking coal and petroleum coke, and other petroleum products not used as fuels. 
III. STATE FUEL PRODUCTION (1977) $(C-6)$

$\begin{array}{ccc}\text { Type Number Units } & \text { Trilition } \\ \text { Btù }\end{array}$

Coal mines

Natural gas (liq.)

Natural gas wells

Crude oil wells

$\begin{array}{cc}1 & 3,247 \text { thousand tons } \\ - & 0 \text { thousand bbl } \\ 4 & 125 \text { milion cu. ft. } \\ 28 & 804 \text { thousand bbl }\end{array}$

70.9

0

0.1

4.7

\section{IV. $\quad$ GEOLOGY}

The southern, western, and extreme northwestern portion of Arizona are in the Basin and Range geologic province. This province consists of northward or northwestern-trending mountain blocks separated by flat, alluvial filled basins with valley floor elevations of 1000 to $2600 \mathrm{ft}$. $(300$ to $800 \mathrm{~m})$. The mountains in general have been uplifted by range-front faulting relative to the basins. Valleys are underlain typically by thousands of feet (several thousand meters) of consolidated to relatively unconsolidated sediments resulting from erosion of the mountain blocks. Exposed mountain rocks include intrusive, extrusive metamorphic, and sedimentary types that are typically folded and faulted. They range in age from Precambrian to Recent.

Northern Arizona is in the Colorado Plateau province. The flat-lying sedimentary rocks from plateaus having typical elevations of $6500 \mathrm{ft}$. $(1700 \mathrm{~m})$ above mean sea level. "The simple geologic structure indicates that the plateau has been relatively stable in the recent geologic past although the margins have been active.

No areas of geyser or fumarolic activity are known to exist; however, several areas of basaltic and rhyolitic volcanism are less than 3 million years old. Four of these areas occur in the Basin and Range province; three areas of young bassaltic volcanism occur in the Colorado Plateau province.

\section{RESOURCE DATA}

There are no confirmed high temperature resources $\left(>300^{\circ} \mathrm{F}\right.$ $\left.\left(150^{\circ} \mathrm{C}\right)\right)$, but several areas are considered as lijkely prospects: Thirty-seven low and moderate temperature $\left(<300^{\circ} \mathrm{F}\left(150^{\circ} \mathrm{C}\right)\right)^{\prime}$ résources have been confirmed in the Basin and Range province and many other areas are condiered likely prospects. Over 2000 hydrothermal springs and wells (many with temperatures greater than $100^{\circ} \mathrm{F}\left(40^{\circ} \mathrm{C}\right)$ have been identified. 


\section{GEOTHERMAL ACTIVITY}

Current use:

Recent studies:
Five sites use water for balneologic purposes.

An extensive exploratory program is being conducted with federal funding by the Arizona Bureau of Geology and Mineral Technology. Geothermal energy space heating is being considered for the Williams Air Force Base near Phoenix and in the design of an IBM plant near Tucson.

\section{LEGAL ACTIVITIES}

Geothermal statutes have been enacted and rules and regulations promulgated. A four year moratorium on leasing state and federal land for geothermal purposes was lifted (1979) following passage of the state law.

\section{CONTACTS}

1. State Geothermal Project Team:

a. Commercialization Planning:

Dr. Frank Mancini, (Arizona Solar Energy Commission); W. Richard Hahman, Sr., (Bureau of Geology and Mineral Technology, University of Arizona).

b. Resource Assessment:

W. Richard Hahman, Sr., (Bureau of Geology and Mineral Technology, University of Arizona).

2. State Oil and Gas Conservation Commission, Wm. C. Allen, Acting Executive Secretary.

3. Water Commission, Wesley Steiner, Executive Director.

4. Department of Economic Planning and Development, Larry Lander, Executive Director; Energy Programs office: Bob Hathaway, Director; and Gerry Cunningham, Director of Energy Programs.

5. Arizona Power Authority, Marshall Humphrey, Chairman.

6. EG\&G Idaho, Inc., P.O. Box 1626 Idaho Falls, Idaho 83401, B. C. Lunis, Commercialization Planning. 
THE JOHNS HOPKINS UNIVERSITY

APPLIED PHYYSICS LABORATORY

LAUREL, MARYLAND

\section{REFERENCES AND IIST OF SIGNIFICANT REPORT}

(1) "Arizona Hydrothermal Commercialization Baseline" EG\&G Idaho, Inc, sep 1979 " (This report contains a bibliography of significant reports and documents.)

\section{COMMON REFERENCES}

$(C-4),(C-6)$, and $(C-7)$. 
ENERGV RESOURCES - 1995
ANNUAL PRODUCTION

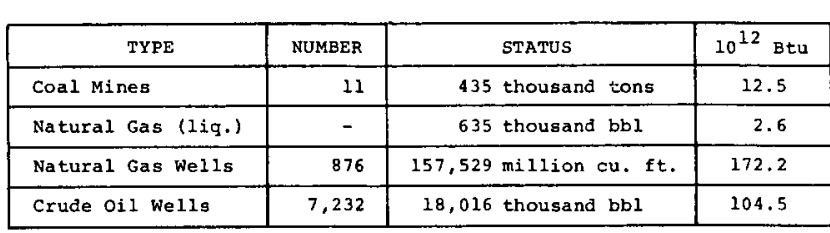

\begin{tabular}{|c|c|c|c|c|c|}
\hline SECCOR & ort & LPG & cas & COALE & $\begin{array}{l}\text { ELECCR: } \\
\text { vevcC: }\end{array}$ \\
\hline GRoss & 274.2 & 38.0 & 270.7 & 0 & 54.2 \\
\hline RESTDENTIAL & $\begin{array}{l}4.5 \\
\end{array}$ & 21.9 & $\frac{50.1}{50}$ & 0 & 21.7 \\
\hline COMMERCIAI & 15.6 & 2.4 & 34.4 & 0 & 14.7 \\
\hline INDUSTRIAL & 34.0 & 12.5 & 140.8 & 0 & 17.7 \\
\hline PERCENT & 47 & 7 & 46 & 0 & \\
\hline
\end{tabular}

GEOTHERMAL ACTIVTIIES

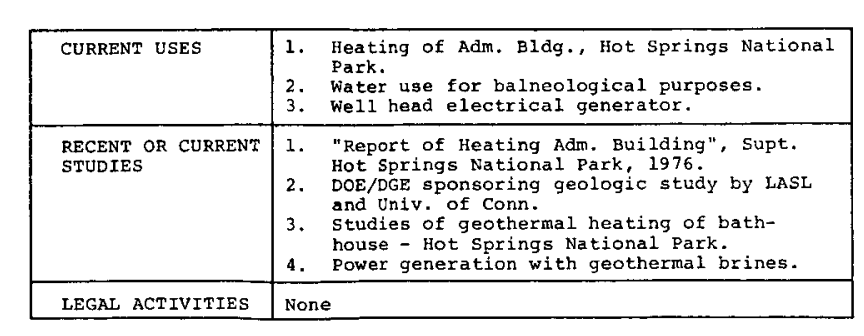

ARKANSAS

GEOTHERMAL DATA S

TOTAL POPULATTON: $1,923,295$ TOOAL AREA: 51,945 SQ.

GEOTHERMAL OVERVIEW Thick sedimentary sequences throughout the state may
harbor hydrothermal resources in areas where above
average geothermal gradient concides with acuiters consolidated sands in Coastal Plain areas have a greater water content. Fini constrild hol springs area appears to represent a hydrothermal area of reasonable size.

- Hos Soring

I8A Imereir Basin Auvites
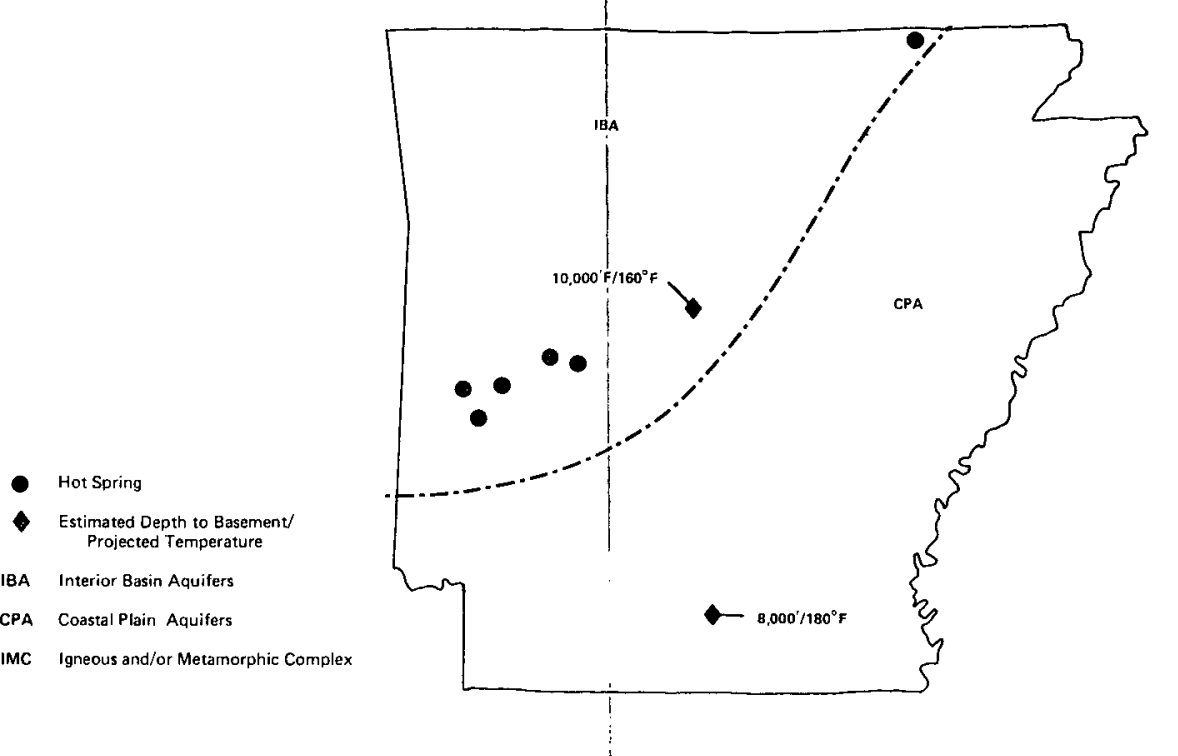

PrIMARY CONTACTS

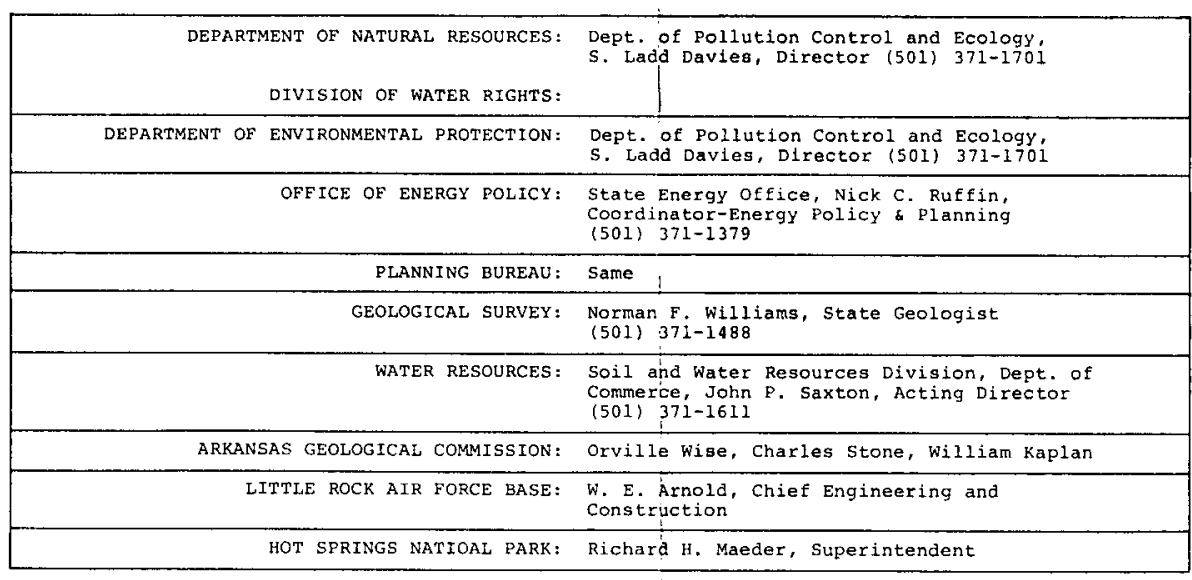

\begin{tabular}{|c|c|}
\hline \multicolumn{2}{|c|}{ LEGISLATIVE CONTACTS } \\
\hline $\begin{array}{lll}\text { sENaroRs } & \begin{array}{l}\text { Davia Pryor } \\
\text { sale Bunpers }\end{array} \\
\text { Dale }\end{array}$ & GOVERNOR Frank D. White (R) \\
\hline COGGRESSNEN (JIST.) & \\
\hline $2-$ Edwin R. Bethune, Jr. (R) & \\
\hline 3 - John P. Harnnerschmidt (R) & \\
\hline $4-$ Bery1 Anthony (D) & \\
\hline
\end{tabular}


State Geothermal Fact Sheet

ARKANSAS

I. DEMOGRAPHIC INFORMATION (1970) (C-4)

TOTAL STATE

Population: 1,923,295 Area: 51,945 sq. mi. Density: 37 per sq. mi. GEOTHERMAL RESOURCE AREA

Population: 858,603 Area: $18,624 \mathrm{sq} \cdot \mathrm{mi}$. Density: $46 \mathrm{per} \mathrm{sq} \cdot \mathrm{mi}$.

II. ENERGY CONSUMPTION* (1975) (C-7)

$\begin{array}{cccccc} & \begin{array}{c}\text { OIL } \\ \text { (million } \\ \text { bbl) }\end{array} & \begin{array}{c}\text { LPG } \\ \text { (million } \\ \text { gal.) }\end{array} & \begin{array}{c}\text { GAS } \\ \text { (trillion } \\ \text { cu.ft.) }\end{array} & \begin{array}{c}\text { COAL } \\ \text { (million } \\ \text { tons) }\end{array} & \begin{array}{c}\text { ELECTRICITY } \\ \text { PURCHASED } \\ \text { (billion kWh) }\end{array} \\ \text { Resos } & 49 & 398 & 262 & 0 & 16 \\ \text { Commerical } & 1 & 230 & 49 & 0 & 6 \\ \text { Industrial } & 3 & 26 & 33 & 0 & 4 \\ \end{array}$

Trillion Btu

\begin{tabular}{|c|c|c|c|c|c|}
\hline GROSS & 274.2 & 38.0 & 270.7 & 0 & 54.2 \\
\hline Residential & 4.5 & 21.9 & 50.1 & 0 & 21 \\
\hline Commercial & 15.6 & 2.4 & 34.4 & 0 & 14. \\
\hline Industrial & 34.0 & 12.5 & 140.8 & 0 & 17. \\
\hline
\end{tabular}

Percentages

47

7

46

0

*Excluding nuclear and hydro electricity, coking coal and petroleum coke, and other petroleum products not used as fuels. 
III. STATE FUEL PRODUCTION (1973) $(C-6)$

Type Number Units cillion

Coal mines

Natural gas (liq.)

Natural gas welis

crude oil wells

$\begin{array}{rr}11 & 435 \text { thousand tons } \\ - & 635 \text { thousand bbl } \\ 876 & 157,529 \text { million cu. ft. } \\ 7,232 & 18,016 \text { thousand bbl }\end{array}$

12.5

2.6

172.2

104.5

IV. $\quad$ GEOLOGY

Cretaceous to Recent unconsolidated sediments of the Gulf Coastal Plain underlie the southeastern half of the state. These sediments form a southeastward thickening wedge that attains a thickness of 15,000 ft. near the juncture of Louisiana and Mississippi. Good aquifers such as the Wilcox and Smackover Formations exist in the Coastal Plain at depths where they should contain hot water.

Beneath these sediments and exposed throughout the rest of Arkansas are lithified Paleozoic sedimentary rocks. These rocks thicken to the south, off the Ozark Uplift centered in Missouri, and into the Arkoma Basin, which attains depths in excess of $35,000 \mathrm{ft}$. Large gas deposits occur in this basin and good aquifers also exist at depth. The Ouachita Mountains have been thrust up over this basin. Hot Springs National Park, which produces $1,000,000$ gallons per day of $143^{\circ} \mathrm{F}$ water, lies at the east end of this mountain belt. These springs are fault controlled and are spatially associated with Mesozoic intrusives (1).

V.

RESOURCE DATA

Geothermal gradients greater than $2^{\circ} \mathrm{F} / 100 \mathrm{ft}$. occur in the Arkoma Basin and beneath the Coastal Plain. These temperatures, where they coexist with deep aquifers, are attractive areas for development of hydrothermal resources.

VI. GEOTHERMAL ACTIVITY

Current use:

Studies :
1. Heating of administration building in Hot Springs National Park.

2. Water use for balneological purposes.

1. Report on heating administration building, Hot Springs National Park, 1976 (2).

2. Report of study to convert bathhouse heating systems from gas to geothermal water (3). 
3. API technical assistance report for converting the Buckstaff and other bathhouses to heating system (4).

4. Arkansas Power and Light Company R\&D project funded by DOE to use hot geothermal brine to vaporize pentane in a closed loop to drive a turbine for power generation. The final report for the first phase should be out by December 1980 (5) and (6).

VII. LEGAL ACTIVITIES

None

VIII. CONTACTS

1. Arkansas Geological Commission, Little Rock, Arkansas (Normal F. Williams [Director], Orville Wise, Charles G. Stone, William Kaplan).

2. U.S. Geological Survey, Little Rock, Arkansas (R. T. Sniegocki, John Hubble, Joseph E. Reed, Boyd Haley).

3. Hot Springs National Park, Hot Springs, Arkansas (Richard H. Maeder, Superintendent).

4. Little Rock Air Force Base, Little Rocli, Arkansas (W. E. Arnold, Chief, Engineering and Construction).

5. Governor's Office, 504 Capitol Hill Bldg., Little Rock, AR 72201, William Onopah, Senior Planner.

REFERENCES AND LIST OF SIGNIFICANT REPORTS

(1) U.S.G.S., "The Waters of Hot Springs National Park, Arkansas - Their Origin, Nature, and Management," Open File Report, Little Rock, Arkansas, 1974.

(2) F. C. Paddison and R. A. Eisenberg, enclosure to "Geothermal Energy and Arkansas," APL/JHU QM-76-104, Aug 1976 .

(3) J. A. Caple, "Feasibility study for the Conversion of Bathhouse Heating Systems from Gas to Geothermal Water," Cromwell, Neyland, Truemper, Levy, and Gathell, Inc., Aug 1978 . 
(4) "Visit to the U.S. Park Service and Buckstaff Bathhouse," Technical Assistance, JHU/APL QM-79-272, Dec 1979. and CQO 2810, Feb 1980 .

(5) "Arkansas Utility to Harness Geothermal Brines," Energy Research Digest, 3 Jul 1978 (also personal communication between Arkansas Power and Light and JHU/APL on 15 Sep 1980).

(6) A. W. Huebner, D. A. Wall, and T. L. Herlacher, "Research and Development of a $3 \mathrm{MW}$ Power Plant from the Design, Development and Demonstration of a $100 \mathrm{~kW}$ Power System Utilizing the Direct Contact Heat Exchanger Concept for Geothermal Brine Recovery Project;" Arkansas. Power and Light Company report for the Department of: Energy, ET 78-G-05-5917, sep 1980 .

\section{COMMON REFERENCES}

$$
(C-4),(C-6), \text { and }(C-7) \text {. }
$$




\section{CALIFORNIA}

GEOTHERMAL DATA SUMMARY SHEET

ENERGY RESOURCES - 1973
ANNUAL PRODUCTION

\begin{tabular}{|c|c|c|c|}
\hline $\operatorname{TYPE}$ & \begin{tabular}{l|l} 
XUMBERR \\
\end{tabular} & 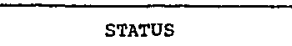 & $10^{12}$ \\
\hline Coa1 Mines & 0 & 0 thousand tons & \\
\hline Natural Gas (1iq.) & - & 12,194 thousand bb1 & 49.2 \\
\hline Natural Gas Kel1s & 1,095 & 449,369 million cu. ft. & 491.2 \\
\hline Crude oil wells & 38,626 & 336,075 thousand bb1 & 1,94 \\
\hline
\end{tabular}

ENERQY USE - 195 10" BTUI

\begin{tabular}{|c|c|c|c|c|c|}
\hline SECTOR & OIL & LPG & GAS & COAs & $\begin{array}{l}\text { ELECT: } \\
\text { PURCH: }\end{array}$ \\
\hline GRoss & 2579.6 & 53.3 & 1928.8 & 54.3 & 490.1 \\
\hline RESSDENTIAY & 16.2 & 11.5 & 651.6 & 0 & 148.0 \\
\hline COMMERCIAL & 39.6 & 1.3 & 207.9 & 0 & 194.3 \\
\hline TrDousrRRAat & 123.0 & 39.9 & 725.1 & 4.1 & 145.8 \\
\hline PERCENT & 56 & 1 & 42 & 1 & \\
\hline
\end{tabular}

GEOTHERMAL ACTIVITIES

\begin{tabular}{|l|l|}
\hline CURRRNT USES & \\
\hline RRCERT OR CURRENT & \\
\hline STUDIPS & \\
\hline PROPBSE STVDDES & \\
\hline LEGGL ACTIVITTIES & \\
\hline
\end{tabular}

TOTAL POPULATTON: $19,957,715$ TOTAL ARBA: 156,361 SQ. MI.

DOOULATYON DENSTTY: 128 P:RSONS/SO

GEOTHERMAL OVERVIEW
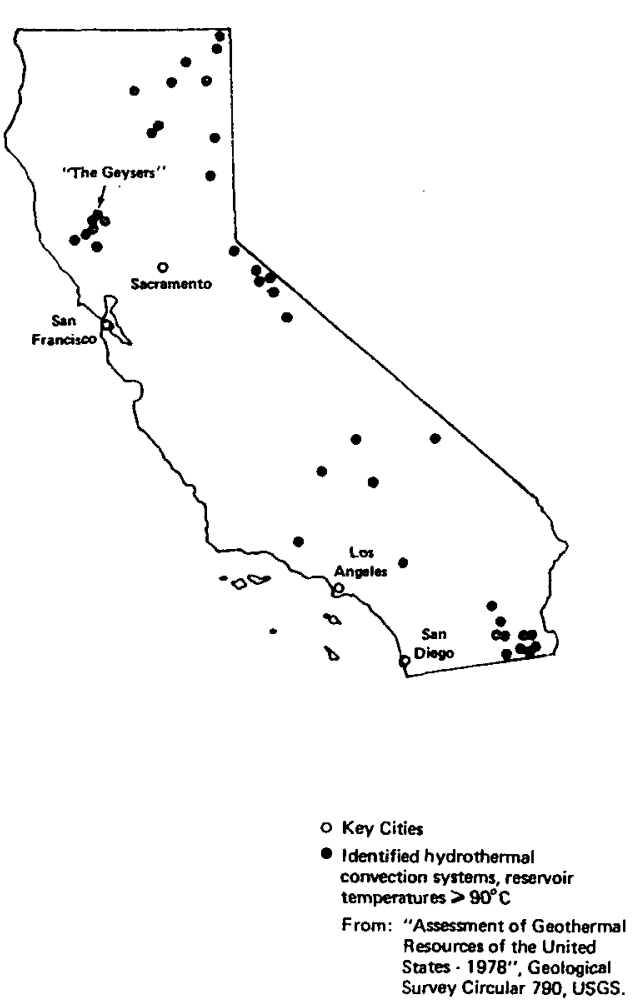

pamapy contacts

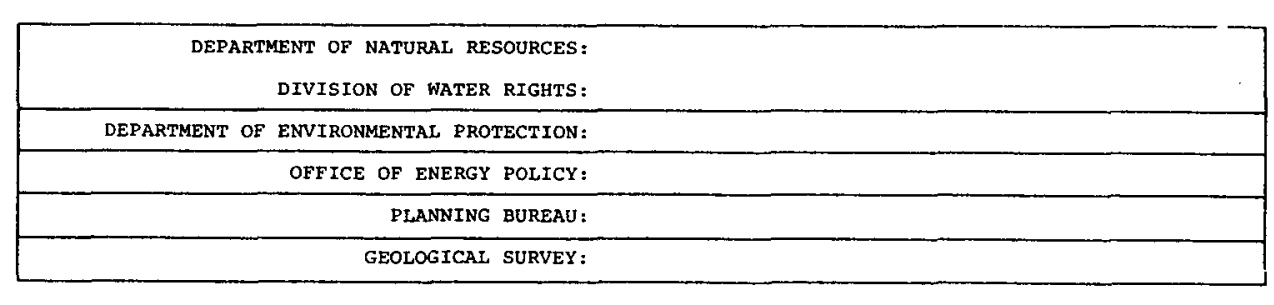

LEGISLATIVE CONTACTS

\begin{tabular}{|c|c|c|}
\hline $\begin{array}{ll} & \text { Alan cranston (D) } \\
\text { SENAPOSS } & \text { S. I. Hayakawa (R) }\end{array}$ & GOVERNOR & Edmund G. Brown, Jx. (D) \\
\hline \multicolumn{3}{|l|}{ ConGresswan (DIST.) } \\
\hline 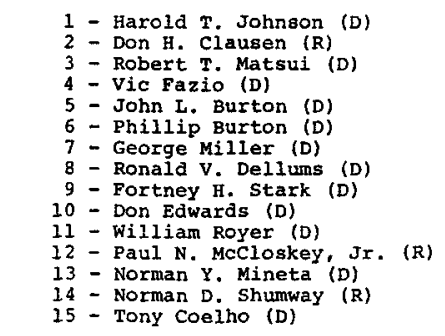 & 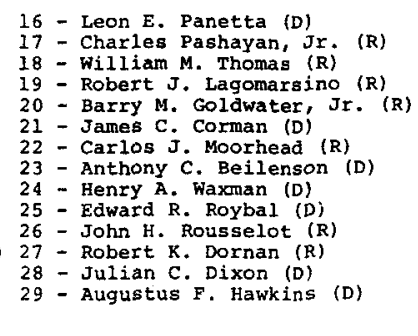 & 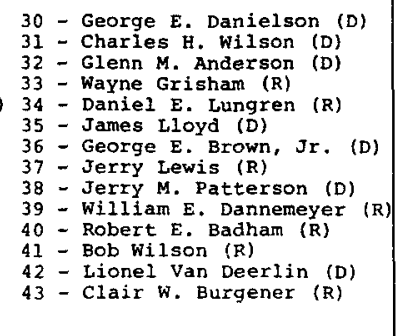 \\
\hline
\end{tabular}


State Geothermal Fact sheet

CALIFORNIA

I. DEMOGRAPHIC INFORMATION (1970) (C-4)

TOTAL STATE

Population: 19,957,715 Area: 156,361 sq. mi. Density: 128 per sq. mi.

GEOTHERMAL RESOURCE AREA

Population:

II. ENERGY CONSUMPTION*

GROSS

Residential

Commerical

Industrial

GROSS

Residential

Commercial

Industrial

Percentages
Area :

sq. mi .

Density :

per sq. mi.

(C-7)

OIL
(million
bbl)

LPG

(million

gal.)

GAS

(trillion

558

120

1869

631

240

418

703

Trillion Btu

$\begin{array}{rrr}2579.6 & 53.3 & 1928.8 \\ 16.2 & 11.5 & 651.6 \\ 39.6 & 1.3 & 247.9 \\ 123.0 & 39.9 & 725.1\end{array}$

56

1

42
ELECTRICITY

PURCHASED

(billion kWh)

144

44

57

43

*Excluding nuclear and hydro electricity, coking coal and petroleum coke, and other petroleum products not used as fuels. 
III. STATE FUEL PRODUCTION (1977) (C-6)

Type Number Units Btiu

Coal mines

Natural gas (liq.)

Natural gas wells

Crude oil wells

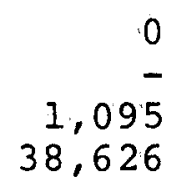

0

5

thous and tons

12,194 thousand bbl

449,369 milion cu. ft.

336,075 thousand bb1
Trillion

$$
\begin{array}{r}
0 \\
49 \cdot 2 \\
49.2 \\
1,949.2
\end{array}
$$

IV. GEOLOGY

California can be divided into the following geologic provinces: Basin and Range (Great Basin and Mohave Désert); Salton Trough; Sierra Nevada; Great valley; Coast Ranges-Traverse Ranges and Peninsular Ranges; Klamath Mountains; Cascade Mountains; and the Modoc Plateau.

Fault-dominated hot water geothermal systems occur in the Basin and Range region of the Great Basin and Mohave Desert. The magmatic upwelling along the East Pacific rise in the Gulf of California has resulted in the high heat flow province of the salton Trough. Cenozoic volcanic centers throughout the state are associated with high temperature resources. The Geysers north of San Francisco is a steam field that produces much of the electricity for that city.

V. RESOURCE DATA

To be determined.

VI. GEOTHERMAL ACTIVITY:

To be determined.

VII. LEGAL ACTIVITIES

To be determined.

VIII. CONTACTS

No data.

REFERENCES AND LIST OF SIGNIFICANT REPORTS

Common references only, see below.

COMMON REFERENCES

$(C-4),(c-6)$, and $(C-7)$.

$$
\text { CA- } 2
$$


ENERGY RESOURCES - 1973
ANNUAL PROOUCTION

\begin{tabular}{|c|c|c|c|}
\hline TYPE & NUMBER & status & $10^{12}{ }_{\mathrm{Btu}}$ \\
\hline Coal Mines & 30 & 6,232 thousand tons & 139.1 \\
\hline Natural Gas (1iq.) & & 3,402 thousand bb1 & 13.7 \\
\hline Natural Gas we11s & 1,050 & 137,725 million cu. $\mathrm{ft}$. & 150.5 \\
\hline Crude oil we11s & 2,004 & 36,590 thousand bb1 & 212.2 \\
\hline
\end{tabular}

ENERGY USE - 1976 110" BTUI

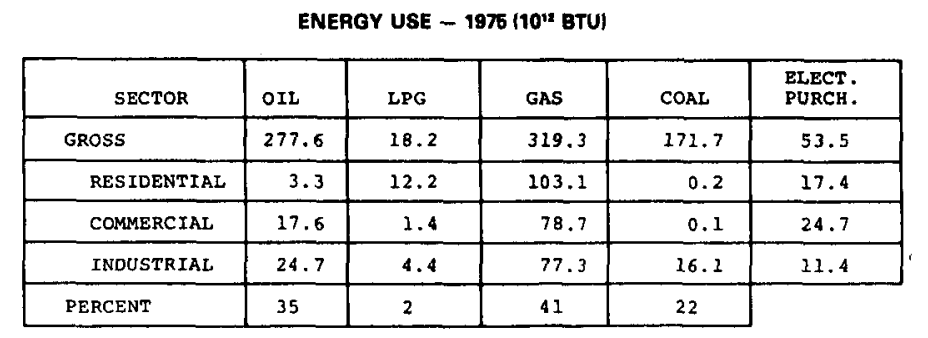

\begin{tabular}{|c|c|}
\hline CURRENT USBS & $\begin{array}{l}\text { labout } 114,000 \text { acres of of } \\
\text { have been } 1 \text { lessed. }\end{array}$ \\
\hline $\begin{array}{l}\text { RECENT OR CURRENT } \\
\text { SYUDIES }\end{array}$ & \\
\hline $\begin{array}{l}\text { PROPOSSD STUDIES } \\
\text { LEGAL ACTIVITIIES }\end{array}$ & sources act was adopted in 197 \\
\hline
\end{tabular}

COLORADO

GEOTHERMAL DATA SUMMARY SHEET

TOTAL POPULATTON: 2, 209,596 TOTAL AREA 104,247 SQ. MT.
POPULATION DENSTYY: 21.2 PERSONS/SQ, MI.

GEOTHERMAL OVERVIEW

The western half of Colorado contains most of the $56 \mathrm{known}$ thententially a hig temperture site, Direct use aptica-

tions are limited because of the sparse population and the
small amount of industry in the west. Evaluation of the
eastern half of the state is yet to be made.

eastern half of the state is yet to be made.

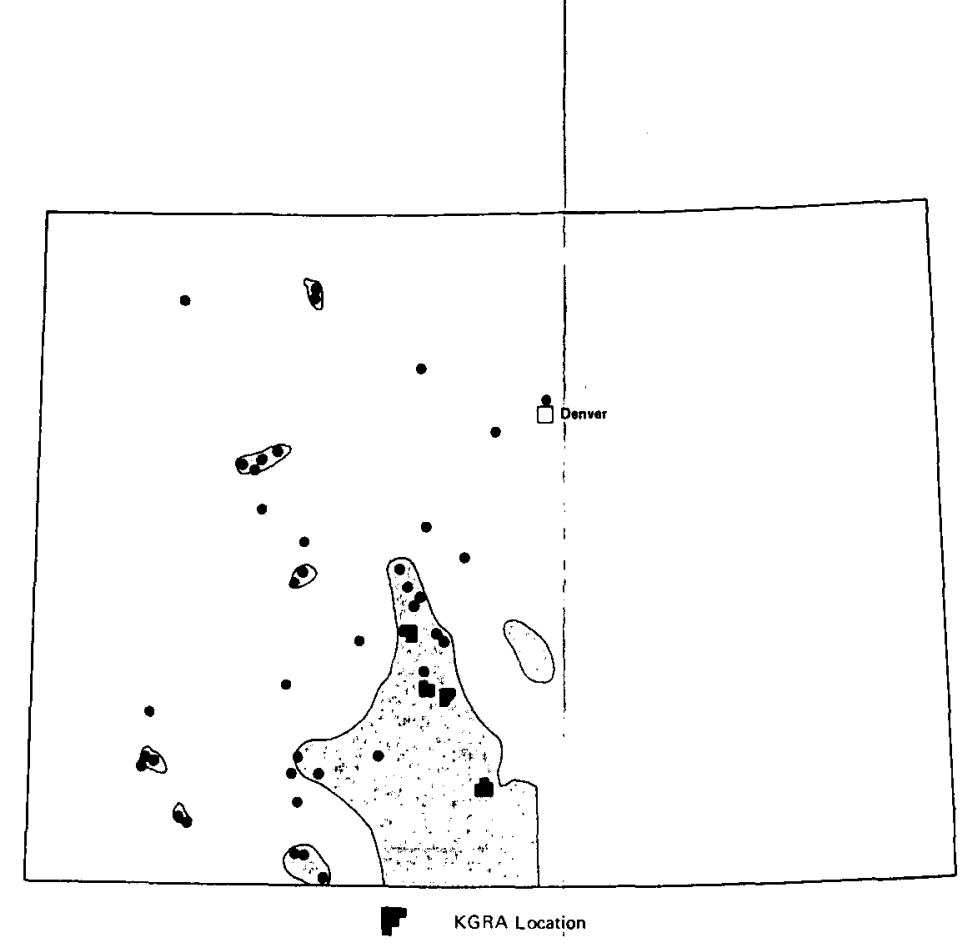

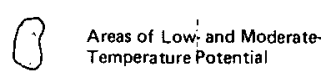

... Hot Springs

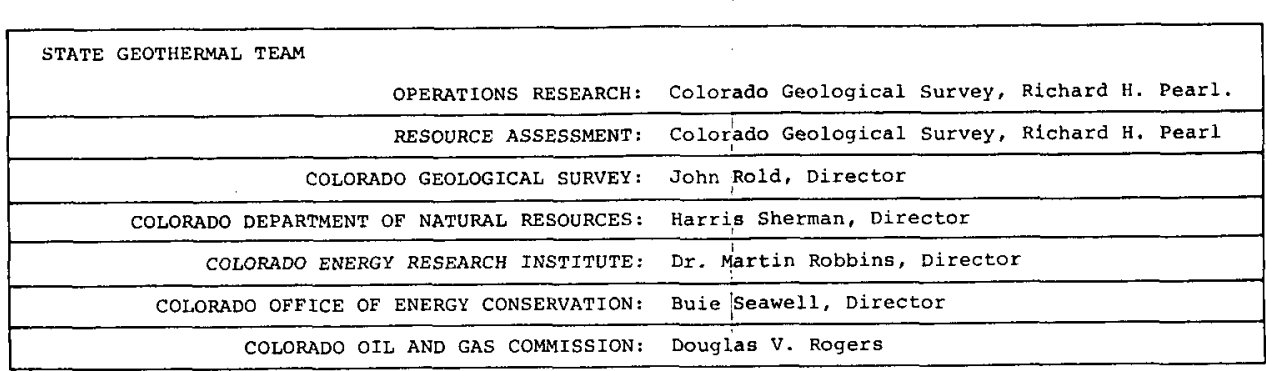

LEGisLATIVE CONTACIS

\begin{tabular}{|c|c|}
\hline 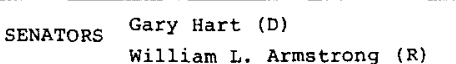 & GOVERNOR Richara D. Lanun (D) \\
\hline CONGRESSNEN (DIST.) & \\
\hline 1 - Patricia schroeder (D) & \\
\hline $\begin{array}{l}2-\text { Timothy E. Wirth (D) } \\
3 \text { - Ray Kogovsek (D) }\end{array}$ & \\
\hline $\begin{array}{l}4 \text { - Hank Brown (R) } \\
5 \text { - Ken Kramer (R) }\end{array}$ & \\
\hline
\end{tabular}


State Geothermal Fact sheet

COLORADO

I. DEMOGRAPHIC INFORMATION (1970) (C-4)

TOTAL STATE

Population: 2,209,596 Area: 104,247 sq. mi. Density:21.2 per sq. mi.

GEOTHERMAL RESOURCE AREA

Population:

II. ENERGY CONSUMPTION*

$(1)$
oll
(million
bbl)

Area :

$\mathrm{sq} \cdot \mathrm{mi}$

$(\mathrm{C}-7)$

LPG (million gal.)

Giss
(trillion
cu.ft.)
309
110
76
75

Residential

Commerical

Industrial

51
1
3
4

190
127
14
46

Trillion Btu

GROSS
Residential
Commercial
Industrial

Percentages

$$
\begin{array}{r}
277.6 \\
3.3 \\
17.6 \\
24.7
\end{array}
$$

35

$\begin{array}{rr}18.2 & 319.3 \\ 12.2 & 103.1 \\ 1.4 & 78.7 \\ 4.4 & 77.3\end{array}$

2

$$
\begin{array}{r}
171.7 \\
0.2 \\
0.1 \\
16.1
\end{array}
$$

22

*Excluding nuclear and hydro electricity, coking coal and petroleum coke, and other petroleum products not used as fuels. 
III. STATE FUEL PRODUCTION (1977) (C-6)

Type Number Units Btu

Coal mines

Natural gas (liq.)

Natural gas wells

Crude oil wells

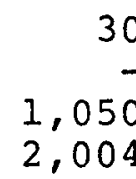

30

6,232

3,402

thousand tons

thousand bbl

$137,725 \mathrm{million} \mathrm{cu}$. ft.

36,590 thousand bbl
139.1

13.7

150.5

212.2

IV. GEOLOGY

The Colorado Plateau Province in the western portion of the state is an area of flat-lying sedimentary rocks with areas of intrusive rocks and a number of young, silicic volcanic systems along the margins of the plateau. The Southern Rocky Mountains occupy the west-central part of Colorado and are composed of uplifted, faulted and folded rocks. To the east is the Great plains Province, which is a flat area of erosional material covering older rocks.

The margin of the Plateau is considered to have the greatest potential for locating high-temperature hydrothermal systems. The interior of the Plateau is thought to have relatively low heat flow. The Great Plains contain no igneous rocks or other encouraging geologic formations. However, recent study of oil well data show some discrete areas in the east that may have direct heat potential.

\section{V. $\quad$ RESOURCE DATA}

There are three areas designated as KGRAs in Colorado. No high temperature reservoirs have been confirmed, but one such prospect exists near Dunton in the southwestern part of the state. Pagosa Springs, in the same general area, has been confirmed as a moderate temperature reservoir. Over 50 other western area sites are considered as prospects for low, medium, and high temperature reservoir confirmation. Some known wells in the east offer potential in the low to moderate category.

VI. GEOTHERMAL ACTIVITY

About 114,000 acres on state and federal land have been leased, 5000 in KGRAs.

About 40 systems using shallow wells and low flows are operational. Most of these are for spas and swimming pools; a few sites are for space heating homes or cabins, greenhouses, fish farming, or algae growing. 
Area and Site Specific Development Plans have been prepared for 23 locations as part of the DOE/state planning process. One Time Phased Project Plan was developed for district heating at Pagosa Springs.

One PON and two PRDAs were awarded in Colorado since 1978, the first in Pagosa Springs for heating public buildings, schools, businesses, and homes; the other dealing with heating and cooling operations in the San Luis Valley.

VII. LEGAL ACTIVITIES

A geothermal resources act was adopted in 1973. Since then specific geothermal leases have been issued.

\section{CONTACTS}

1. State Geothermal Team:
a. Operations Research, Colorado Geological Survey, Richard H. Pearl.
b. Resource Assessment, Colorado Geological Survey, Richard H. Pearl.

2. Colorado Geological Survey, John Rold, Director.

3. Colorado Department of Natural Resources, Harris Sherman, Director.

4. Colorado Energy Research Institute, Dr. Martin Robbins, Director.

5. Colorado Office of Energy Conservation, Buie Seawell, Director.

6. Colorado Oil and Gas Commission, Douglas V. Rogers.

\section{REFERENCES AND LIST OF SIGNIFICANT REPORTS}

(1) "Colorado Hydrothermal Commercialization Baseline," EG\&G Idaho, Inc., Apr 1979.

\section{COMMON REFERENCES}

$(c-4),(c-6)$, and $(C-7)$. 
CONNECTICUT

GEOTHERMAL DATA SUMMARY SHEET

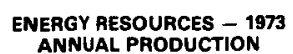

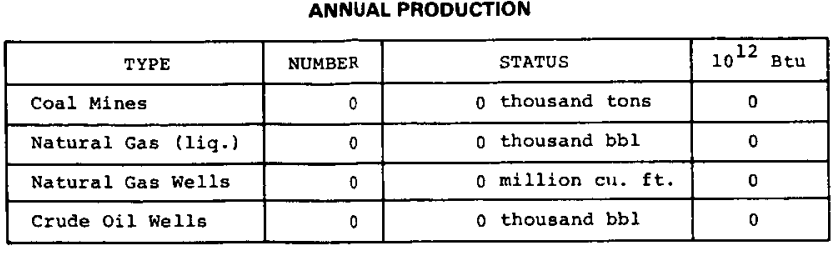

ENERQY USE - 1975 110" BTU

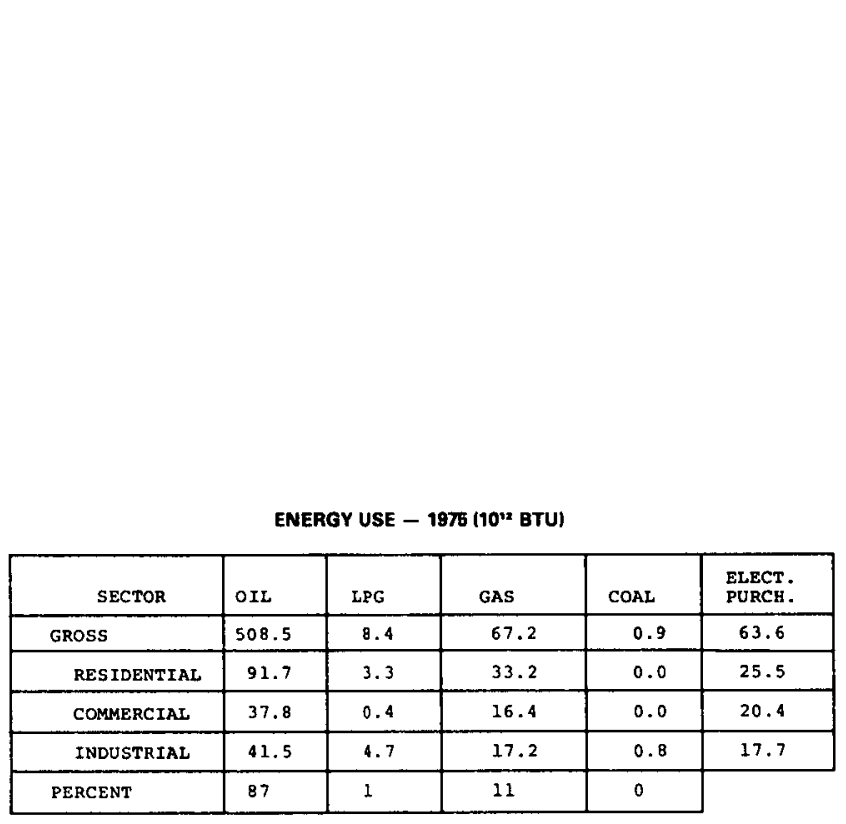

GEOTHERMAL ACTIVTTIES

\begin{tabular}{|c|c|}
\hline CURRENT USES & Wone known \\
\hline $\begin{array}{ll}\text { RECENT OR CURRENT } \\
\text { STUDISTS }\end{array}$ & None known \\
\hline PROPOSED STUDIES & None knoum \\
\hline LEGAL ACTIYYTIPS & None known \\
\hline
\end{tabular}

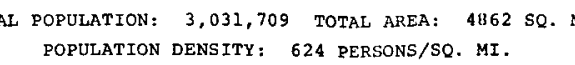

GEOTHERMAL OVERVIEW

Hot dry rock andor hydrothermal potential may exist at

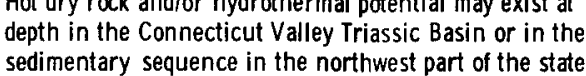

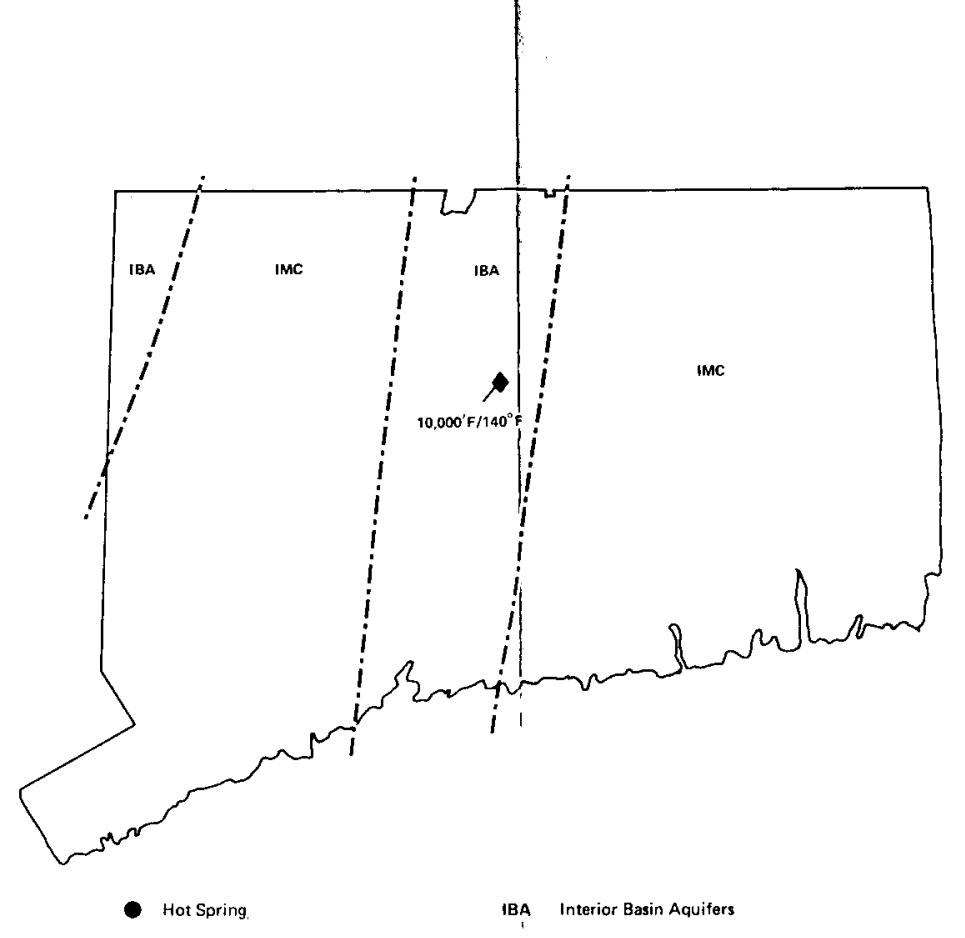

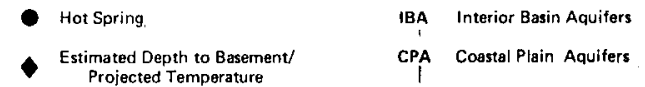
cossa Plain Aaviters

PRIMARY CONTACTS

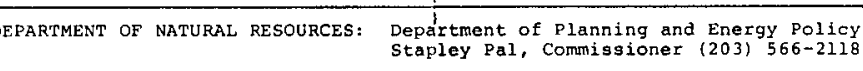

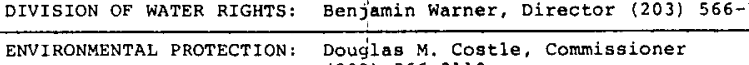

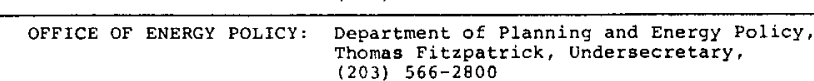
PLANNIMG BUREAV: Horace H. Brown, Di rector (203) $566-4872$ GBOLOCICAL SURVEY: Dr. Hugo F. Thomas, State Geologist

IEGILLATIVE CONTACTS

\begin{tabular}{|c|c|}
\hline 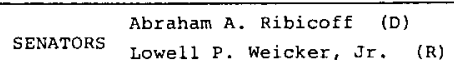 & GOVERNOR E11a T. Grasso (D) \\
\hline $\begin{array}{l}\text { CONGRESSMEN (DIST.) } \\
\text { * - Wil1iam R. Cotter (D) }\end{array}$ & \\
\hline 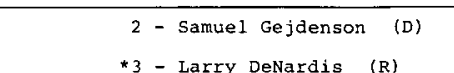 & \\
\hline $\begin{array}{l}4 \text { - Stewart B. Mckinney (R) } \\
* 5 \text { - william Ratchford (D) }\end{array}$ & \\
\hline${ }^{* 6}-$ Anthony Mof fett $\quad(D)$ & * Those in this State IBA Regior \\
\hline
\end{tabular}



Type

Coal mines

Natural gas (liq.)

Natural gas welis

Crude oil wells
Number

\section{0}

0

0

0

\section{Units}

0 thousand tons

0 thousand bbl

0 million cu. ft.

0 thousand $\mathrm{bbl}$
Trilition

Btu

0
0
0
0

IV. GEOLOGY

Connecticut is largely underlain by Precambrian and Paleozoic metamorphic and igneous rocks that were deformed or emplaced during the Paleozoic orogenies. In the central part of the state, the north-south trending Connecticut Valley-Triassic Basin has downdropped Mesozoic sedimentary rocks into the crystalline terrain. This basin has the appearance of a half-graben with as much as 15,000 ft. of sediments preserved along its eastern margin.

V. RESOURCE DATA

Little is known about water availability at the depths cited. However, the highly indurated and noncalcareous nature of most of the sequence suggests the importance of fractures and faults for the circulation of water. Subsurface temperature data are rare.

VI. GEOTHERMAL ACTIVITY

To be determined.

VII. IEGAL ACTIVITIES

To be determined.

VIII. CONTACTS

1. Department of Planning and Energy Policy, Stapley Pal, Commissioner, (203) 566-2118.

2. Division of Water Rights, Benjamin Warner, Director, (203) 566-7220.

3. Department of Environmental Protection, Douglas M. Costle, Commissioner, (203) 566-2110.

4. Department of Planning and Energy Policy, Thomas Fitzpatrick, Undersecretary, (203) 566-2800. 
5. Planning Bureau, Horace H. Brown, Director, (203) 566-4872.

6. Dr. Hugo F. Thomas, State Geologist (203) 566-3540.

REFERENCES AND LIST OF SIGNIFICANT REPORTS

Common references only, see below.

COMMON REFERENCES

$(C-1),(c-4),(c-6),(c-7)$, and $(C-10)$. 
ENERGY RESOURCES - 1973
ANNUAL PROOUCTION

\begin{tabular}{|c|c|c|c|}
\hline TYPE & NUMBER & starus & $10^{12} \mathrm{Btu}$ \\
\hline Coal Mines & 0 & 0 thousand tons & 0 \\
\hline Natural Gas (1iq.) & 0 & 0 thousand bb1 & 0 \\
\hline Natura1 Gas wel1s & 0 & 0 million cu. $\mathrm{ft}$ & 0 \\
\hline Crude oil we 11s & 0 & 0 thousanan bb1 & 0 \\
\hline
\end{tabular}

QNERAY USE - 1975 (10" BTU)
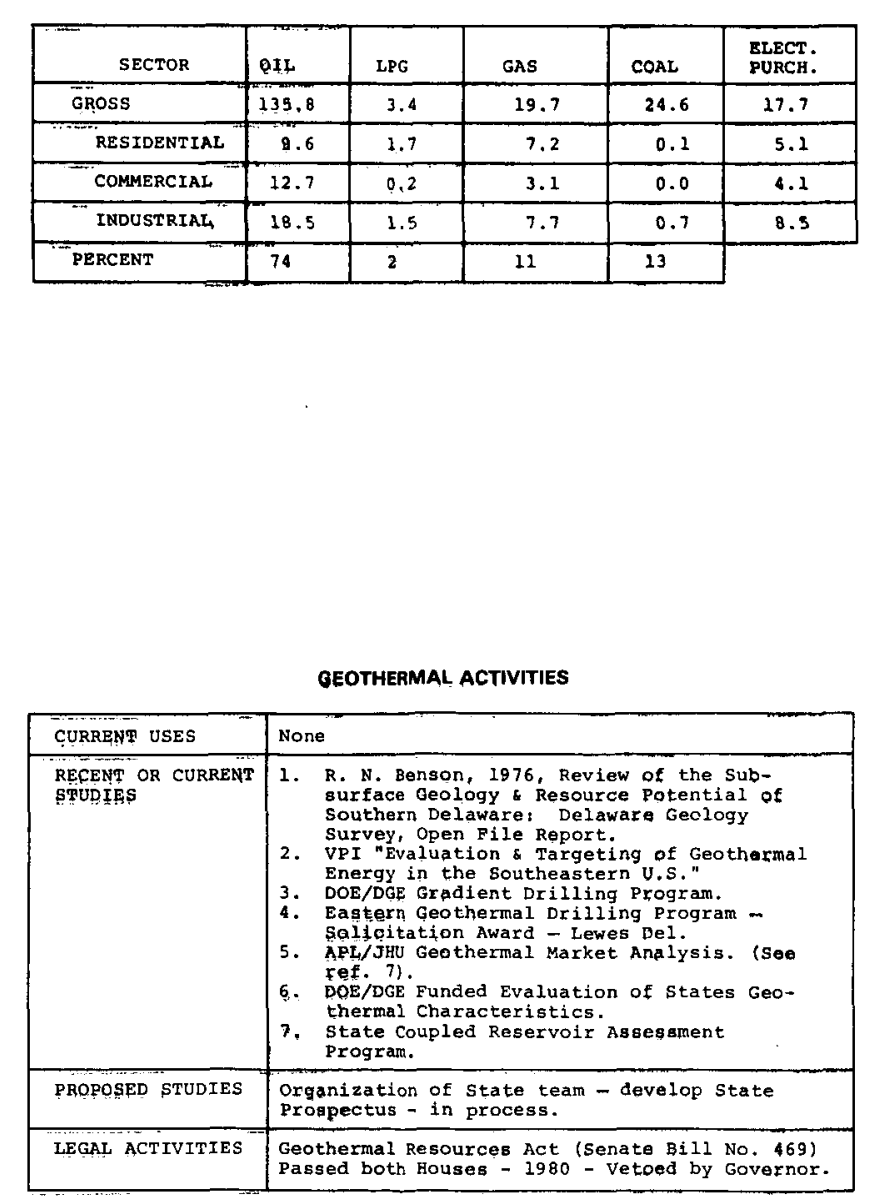

GEOTHERMAL DATA SUMMARY SHEET

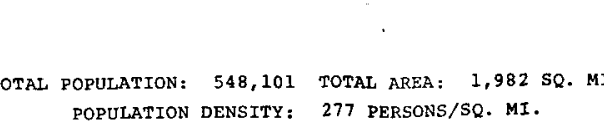

GEOTHERMAL OVERVIEW

Lower Eastern Delaware is underl lain by unconsolidated Coastal Plain sediments. The basement beneath the sedi-
ments has been interpreted by by viles to to contain plutons

ments has been interpretede by VPI\&SU to contain plutons
that may produce radiogenic heat. Data on aquifiers above

plutons needs to be developed. Depth to basement increases

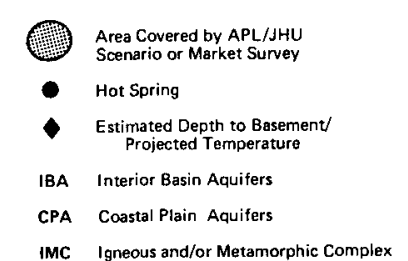

18A Interior Bsis A Auiter

inc Igneous and/or Metamorphic complex

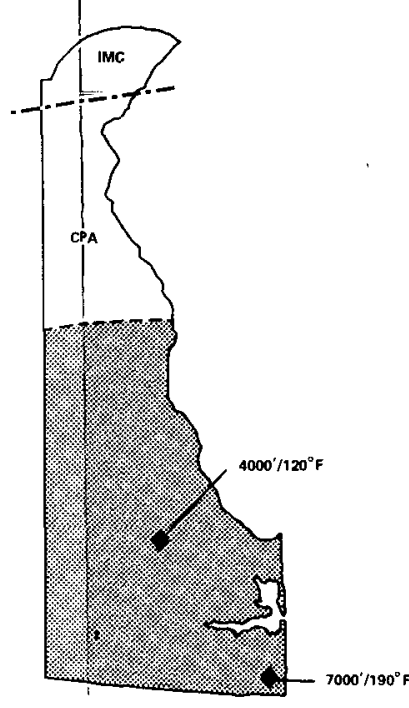

PRIMARY CONTACTS

DEPARTMENT OF NATURAL RESOUvCES: John c.. Byson, Secretary (302) 678-440.3 (3) STARE ENERGY OFF ICE: Chris warner (302) $678-56544$ (2) Chris warner (302) 678-5644

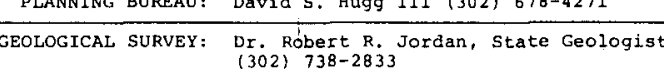
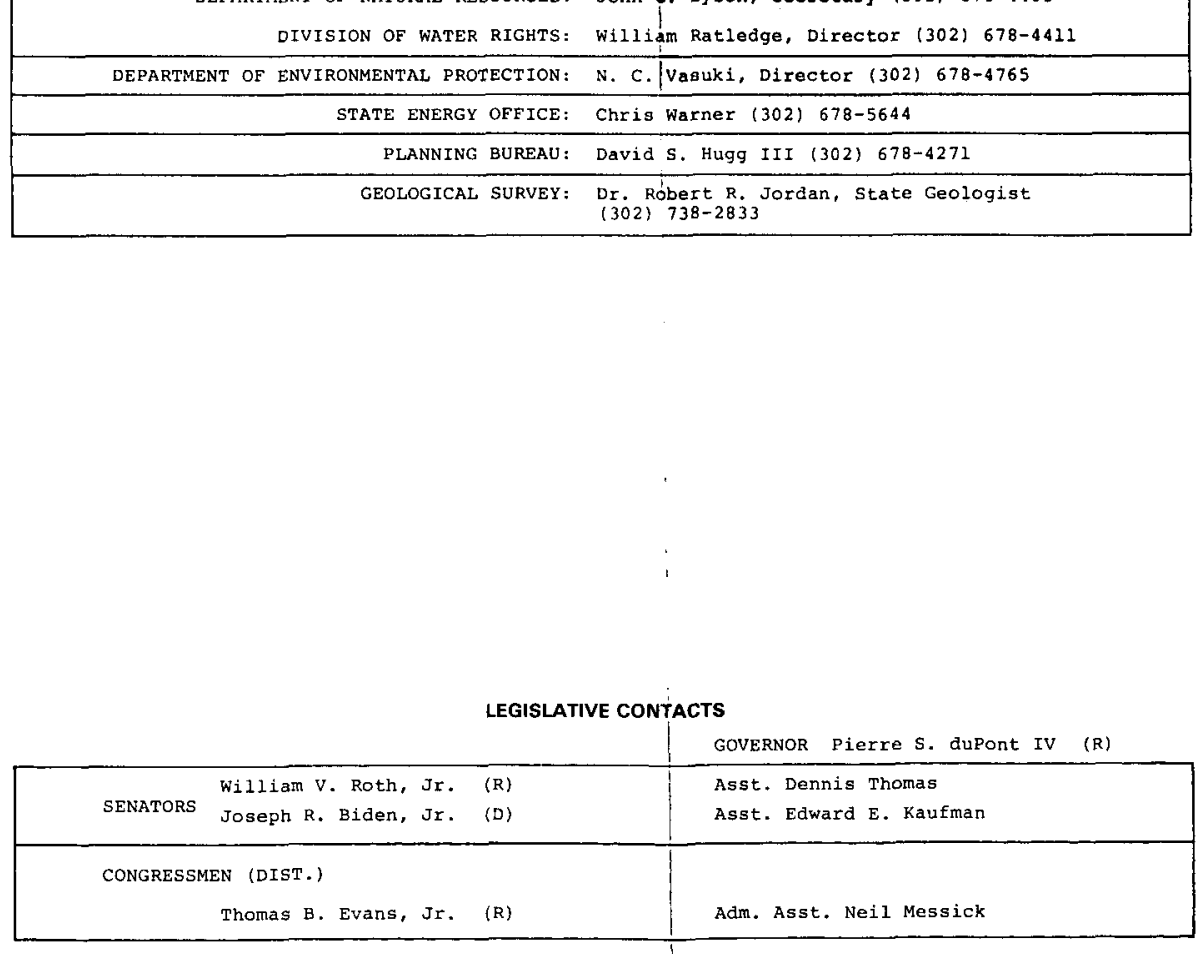
State Geothermal Fact Sheet

DELAWARE

I. DEMOGRAPHIC INFORMATION (1970) (C-4)

TOTAL STATE

Population: 548,101 Area: 1,982 sq. mi. Density: 277 per sq. mi. GEOTHERMAL RESOURCE AREA

Population: 162,245 Area: 1,544 sq. mi. Density: 105 per sq. mi.

II. ENERGY CONSUMPTION* (1975) (C-7)

\begin{tabular}{|c|c|c|c|c|}
\hline 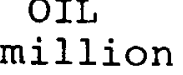 & $\begin{array}{c}\text { LPG } \\
\text { (million }\end{array}$ & $\begin{array}{c}\text { GAS } \\
\text { (trillion }\end{array}$ & $\begin{array}{c}\text { COAL } \\
\text { (million }\end{array}$ & $\begin{array}{c}\text { ELECTRICITY } \\
\text { PURCHASED }\end{array}$ \\
\hline
\end{tabular}

GROSS

Residential

Commerical

gal.

cu.ft.)

tons)

(billion kWh)

Industrial

$\begin{array}{rr}23 & 35 \\ 2 & 18 \\ 2 & 2 \\ 3 & 15\end{array}$

19

1

0.00

0

15

7
3

Trillion Btu

GROSS
Residential
Commercial
Industrial

Percentages

$$
\begin{array}{r}
135.8 \\
9.6 \\
12.7 \\
18.5
\end{array}
$$

74

$\begin{array}{rr}3.4 & 19.7 \\ 1.7 & 7.2 \\ 0.2 & 3.1 \\ 1.5 & 7.7\end{array}$

2

$$
\begin{array}{r}
24.6 \\
0.1 \\
0.0 \\
0.7
\end{array}
$$

17.7

5.1

4.1

8.5

13

\footnotetext{
*Excluding nuclear and hydro electricity, coking coal and petroleum coke, and other
} petroleum products not used as fuels. 
III. STATE FUEL PRODUCTION (1973) (C-6)

Type Number Units $\quad$ Trilion

Coal mines

Natural gas (1iq.)

Natural gas welis

crude oil wells
0

0

0

0
0 thousand tons 0

0 thousand $\mathrm{bbl} \quad 0$

0 milition cu. ft. 0

0 thousand bbl o

\section{GEOLOGY}

The coastal plain encompasses most of the state and is thought to consist of a southeasterly thickening wedge of Mesozoic and cenozoic sedimentary rocks. An irregular but generally seaward sloping contact separates the basement complex from the overlying sedimentary package. Maximum depth to basement is about $7500 \mathrm{ft}$. and occurs near the southeast corner of the state (1). The concept of a gently sloping basement surface is being challenged as more geophysical data are made available (2).

V.

$\underline{\text { RESOURCE DATA }}$

Little is known of the resource other than that it is thought to extend into Delaware from the vicinity of Ocean City, Maryland. More specific data will result from the DOE/DGE sponsored drilling program along the Coastal Plain.

VI. GEOTHERMAL ACTIVITY

Geothermal-gradient test holes have been completed as part of the DOE/DGE sponsored drilling program (6). Data are being assessed by VPI\&SU (5). Drilling sites are shown on page DE-5. API has completed the study of the potential geothermal market in the area (4). The state Energy office submitted a winning proposal for Geothermal Energy at Lewes, Delaware, in response to Eastern Geothermal Drilling Program, June 1980 (9). DOE/DGE State Coupled Reservoir Assessment Program.

VII. LEGAL ACTIVITIES

NCSL has conducted survey of Legislative Work Shops relating to Geothermal energy (7). Geothermal Resource Act Senate Bill No. 469 was passed by both Houses, but was vetoed by the Governor.

VIII. CONTACTS

1. Delaware Energy Office, P. O. Box 1401, 114 W. Water Street, Dover, DE 19901, Chris Warner, or Dave Anstire (Governor's Energy Advisor), (302) 678-5644. 
2. Division of Environmental Control, Department of Natural Resources, Tatnall Building, Dover, DE 19901, N. C. Vasuni, Director, (302) 678-4765.

3. Environmental Policy and Community Development Services, State Planning Office, Thomas Collins Building, Dover, DE 1990I, David S. Hugg III, Principal Planner, (302) $678-4271$.

4. National Legislative Representatives

a. Senate - Mr. William V. Roth, Jr. (Republican) Adm. Asst., Mr. Dennis Thomas Mr. Joseph R. Biden, Jr. (Democrat) Adm. Asst., Mr. Edward E. Kaufman

b. Representatives - Mr. Thomas B. Evans, Jr. (Republican) Adm. Asst., Mr. William T. Kendall

\section{REFERENCES AND LIST OF SIGNIFICANT REPORTS}

(1) P. M. Brown, J. A. Miller, and F. M. Swain, "Structural and Stratigraphic Framework, and Spatial Distribution of Permeability of the Atlantic Coastal Plain, North Carolina to New York," U.S.G.S. Professional Paper 796, 1972 .

(2) R. N. Benson, "Review of the Subsurface Geology and Resource Potential of Southern Delaware," Delaware Geology Survey, Open File Report, 1976.

(3) "Geothermal Energy and the Eastern U.S., A Scenario for Geothermal Energy Development, The Atlantic Coastal Plain," QM-77-129, Oct 1977.

(4) "Definition of Markets for Geothermal Energy in the Northern Atlantic Coastal Plain," JHU/APL QM-80-075 (GEMS-002), May 1980.

(5) "Evaluation and Targeting of Geothermal Energy Resource in the Southeastern United States," VPI\&SU, Blacksburg, VA (a series of reports).

(6) L. B. Cobb, I. Radford, and M. Glascock, "Atlantic Coastal Plain Geothermal Test Holes, Delaware," NVO1558-2, Gruy Federal, Inc., Houston, TX, Mar 1979.

(7) "Geothermal Policy Project - Quarterly Report," National Conference of State Legislatures, Denver, CO (a series of reports). 
(8) "Geothermal Energy and the Eastern U.S." Technitca 1 Information Exchange Meeting," APL/JHU QM-79-261: Chapter XXV - W. Woodruff, "Geothermal studies, Delaware", and Comments Relating to Application at "Town of trewe's."

(9) Solicitation for Cooperative Agreement (SCA) Number DE-RP07-80ID12132, "Eastern Geothermal "Driling Project," U.S. Department of Energy, Idaho operations office, 19 Mar 1980.

\section{COMMON REFERENCES}

$(C-4),(C-6),(C-7)$, and $(C-8)$. 


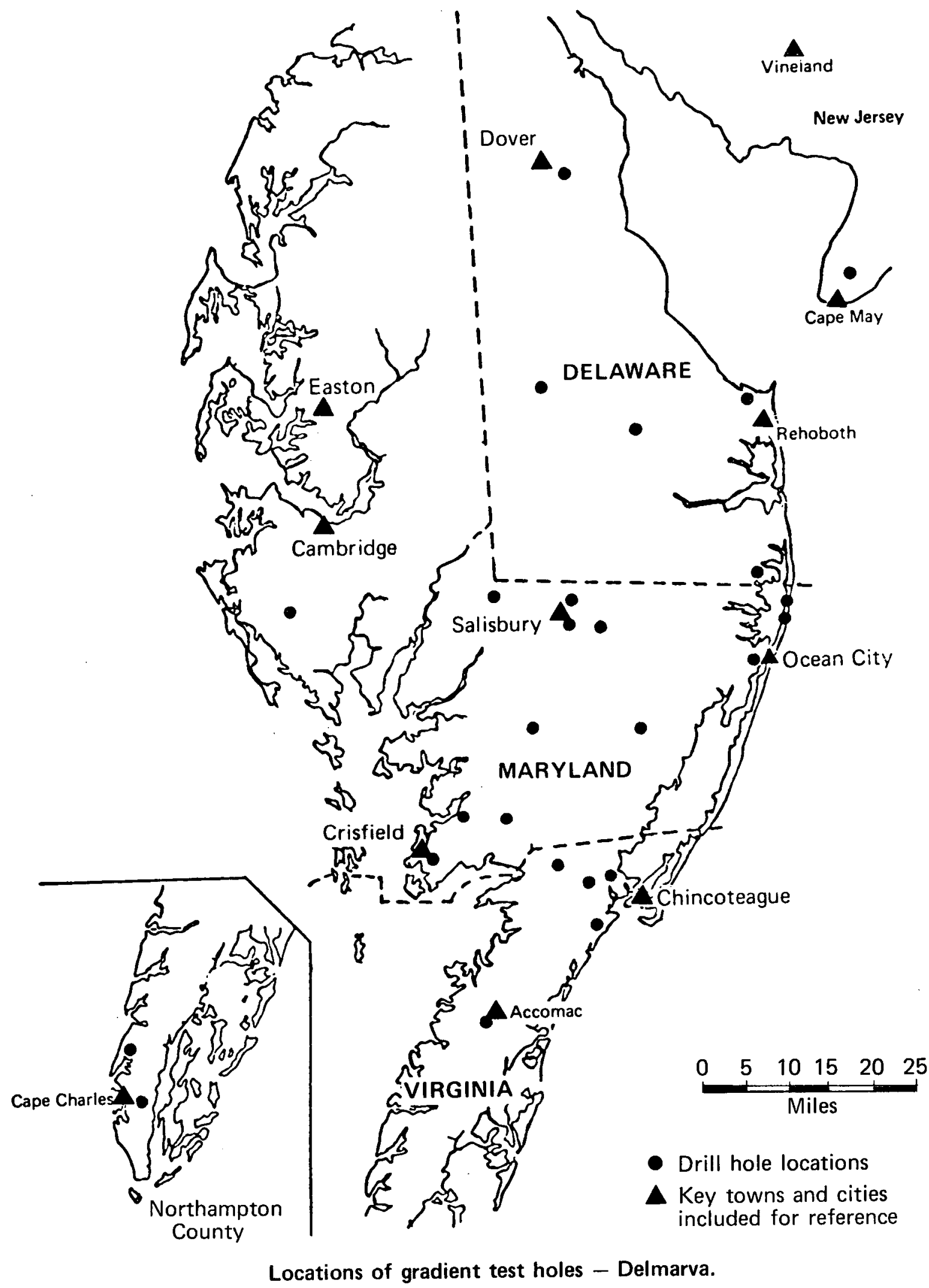

$\partial E-5$ 
FLORIDA

GEOTHERMAL DATA SUMMARY SHEET (cf. State Geothermal Fact sheet, Florida)

GEOTHERMAL RESOURCE DATA

\begin{tabular}{|c|c|c|c|}
\hline NAMS & ${ }_{\text {Central } 1 \text { F1orida }}^{(1)}$ & $\begin{array}{l}(2) \\
\text { Southern F1orida }\end{array}$ & F1orida $\stackrel{(3)}{\text { Panhandie }}$ \\
\hline TYPE & $\begin{array}{l}\text { Limestone or } \\
\text { dolomite }\end{array}$ & $\begin{array}{c}\text { Limestone or or } \\
\text { dolomite }\end{array}$ & Clastic sediments \\
\hline DEPTH & $\begin{array}{l}4,000 \text { to } \\
15,000 \mathrm{ft} .\end{array}$ & $\begin{array}{l}15,0000 \text { to } \\
25,000 \mathrm{ft} .\end{array}$ & $\begin{array}{l}5,000 \text { to } \\
20,000 \mathrm{ft} .\end{array}$ \\
\hline WATER TEMP. & $120^{\circ}$ to $212^{\circ} \mathrm{F}$ & $212^{\circ}$ to $300^{0^{+} \mathrm{F}}$ & $120^{\circ}$ to $300^{\circ} \mathrm{F}$ \\
\hline $\begin{array}{l}\text { EST. STORED } \\
\text { WATER }\end{array}$ & $\begin{array}{l}2.1 \times 1 \times 10^{14} \\
\text { eu. } \\
\text { ett. }\end{array}$ & $\begin{array}{l}4.14 \times 10^{14} \\
\text { cu. } \mathrm{Ft}\end{array}$ & $\begin{array}{c}1.5 \times 10^{14} \\
\text { cu. } \mathrm{ft}^{14}\end{array}$ \\
\hline $\begin{array}{l}\text { EST. ENERGY } \\
\text { CONTENT }\end{array}$ & $\begin{array}{c}\text { over } 600 \\
\times \quad 10^{15} \\
\end{array}$ & $\begin{array}{c}\text { over } 2,000 \\
\times 10^{15} \mathrm{Btu}\end{array}$ & $\begin{array}{r}\text { Excess of } 500 \\
\times \quad 10^{15} \\
\mathrm{Btu}\end{array}$ \\
\hline
\end{tabular}

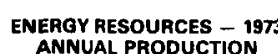

\begin{tabular}{|c|c|c|c|}
\hline TYPE & NUMBER & starus & $10^{12} \mathrm{Btu}$ \\
\hline coal Mines & 0 & 0 thousand tons & \\
\hline Naturat Gas (11q.) & & 2,133 thousand bo 1 & 8.6 \\
\hline Natura1 Gas We11a & $=$ & $33,857 \mathrm{~m}$ i11 ion cu. $\mathrm{ft}$. & 37 \\
\hline Crude oi1 we118 & 2.47 & 32,695 thousand bb1 & 189.6 \\
\hline
\end{tabular}
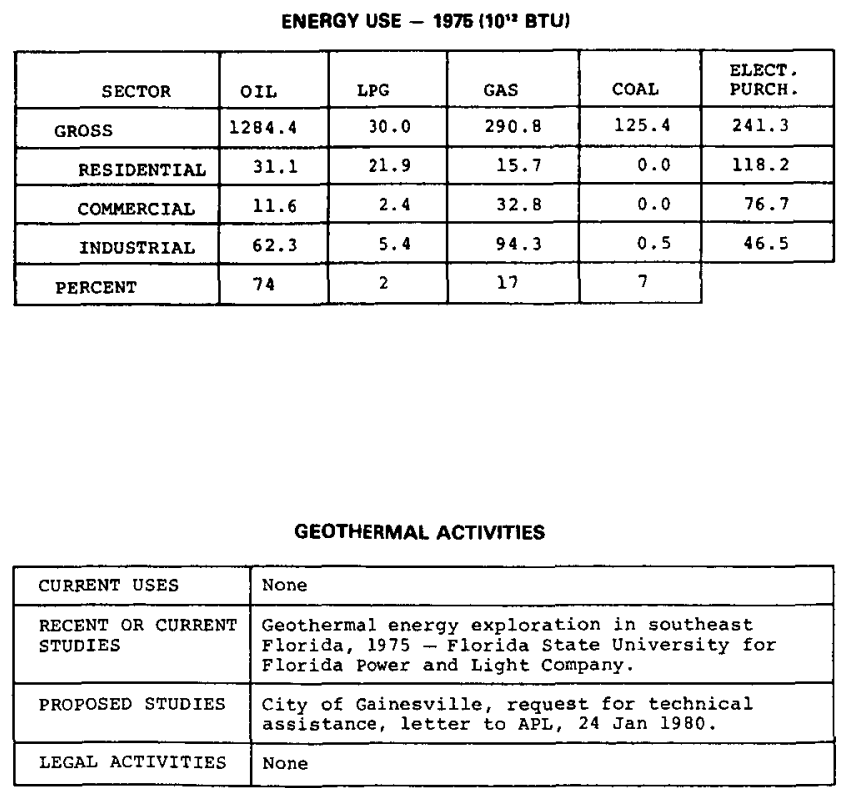

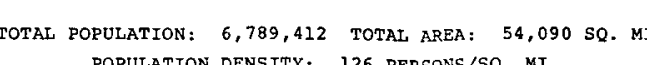

GEOTHERMAL OVERVIEW

Thick sedimentary seguences underlay most of Florida.

Irom shall low wells and that are also infiuenced by copio-s bonte sequnces in Florida meke depen well drilling dift-

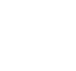

of the state is possibly due to sparse data that are taken

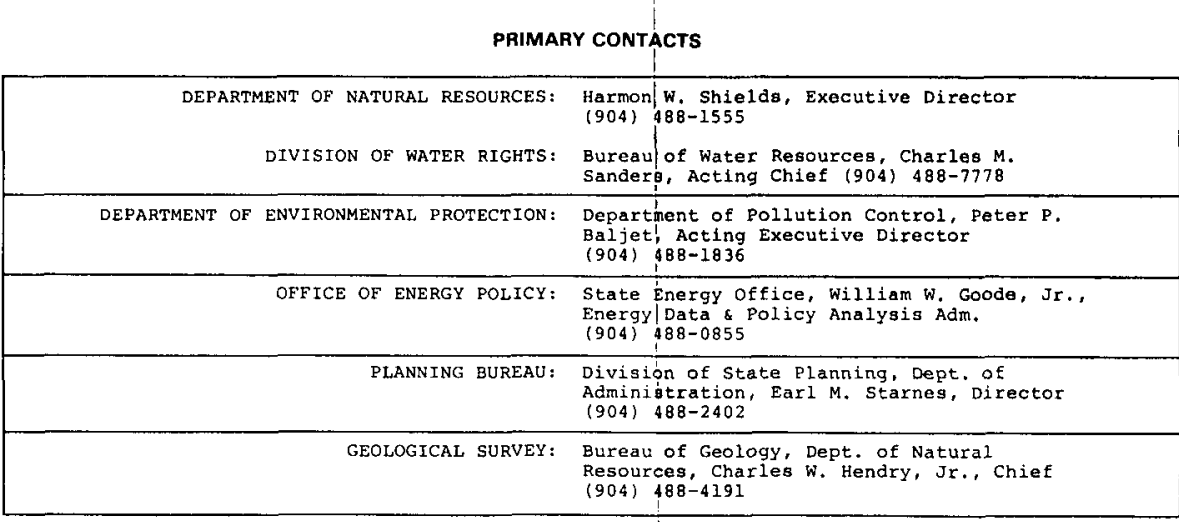

(1) Area Covered by APLJ/JHU
scenario or Market Surver

- Hotsoring

- Estimated e epont to Basement

IBA Intraior Basin Auvithe

CPA Cossta Plin Aquiters

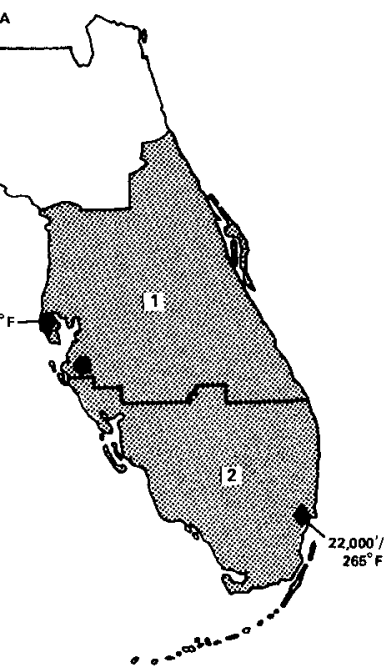

i

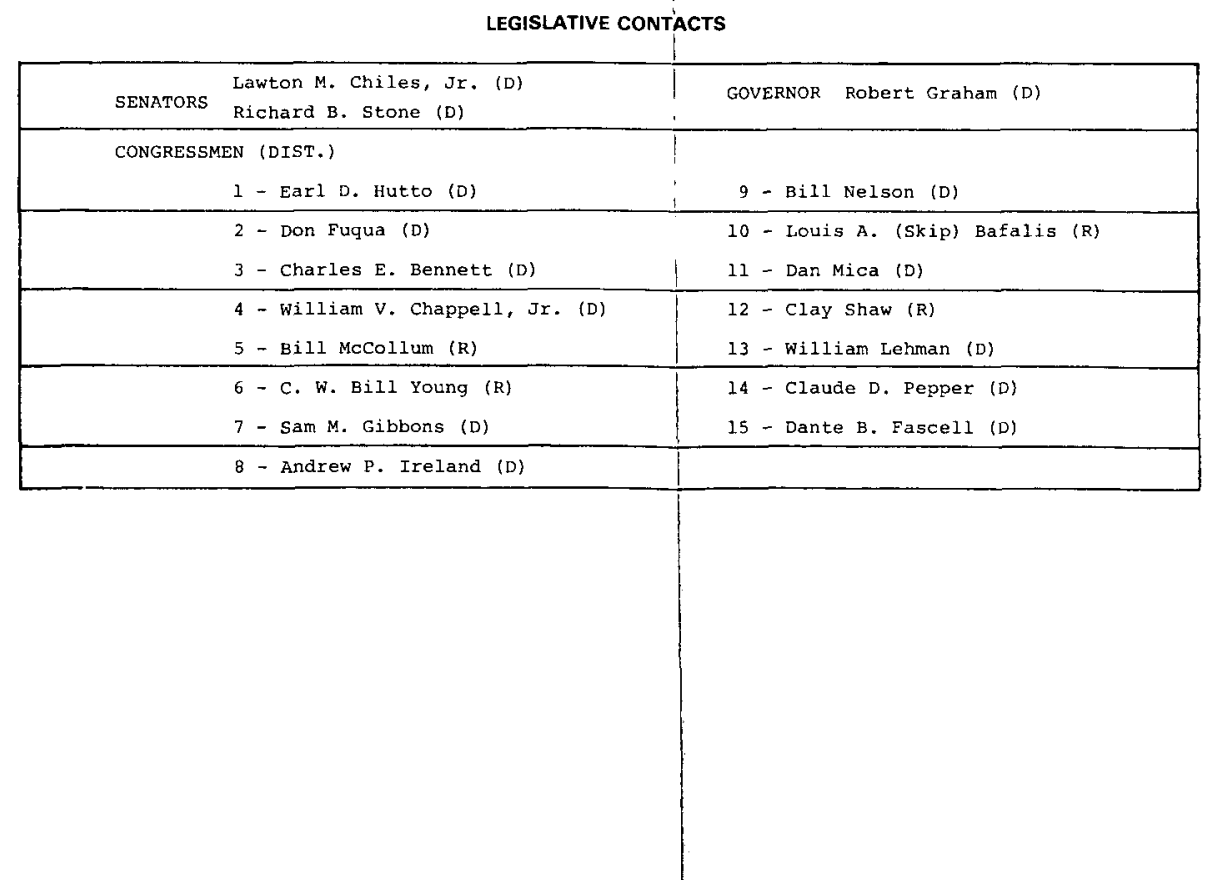


State Geothermal Fact sheet

FLORIDA

I. DEMOGRAPHIC INFORMATION (1970) (C-4)

TOTAL STATE

Population: 6,789,412 Area: 54,090 sq. mi. Density: 126 per sq. mi. GEOTHERMAL RESOURCE AREA

Population: 5,862,000 Area: 42,400 sq. mi. Density: 138 per sq. mi.

II. ENERGY CONSUMPTION* (1975) (C-7)

\begin{tabular}{|c|c|c|c|c|c|}
\hline & $\begin{array}{l}\text { OIL } \\
(\mathrm{million} \\
\text { bbI) }\end{array}$ & $\begin{array}{l}\text { LPG } \\
\text { (million } \\
\text { gal.) }\end{array}$ & $\begin{array}{l}\text { GAS } \\
\text { (trilizion } \\
\text { cu.ft.) }\end{array}$ & $\begin{array}{l}\text { COAL } \\
\text { (million } \\
\text { tons) }\end{array}$ & $\begin{array}{l}\text { ELECTRICITY } \\
\text { PURCHASED } \\
\text { (billion kWh) }\end{array}$ \\
\hline $\begin{array}{l}\text { GROSS } \\
\text { Residential } \\
\text { Commerical } \\
\text { Industrial }\end{array}$ & $\begin{array}{r}226 \\
5 \\
2 \\
10\end{array}$ & $\begin{array}{r}314 \\
229 \\
25 \\
56\end{array}$ & $\begin{array}{r}282 \\
15 \\
32 \\
91\end{array}$ & $\begin{array}{l}6 \\
0 \\
0 \\
0.02\end{array}$ & $\begin{array}{l}71 \\
35 \\
22 \\
14\end{array}$ \\
\hline \multicolumn{6}{|c|}{ Trillion Btu } \\
\hline $\begin{array}{l}\text { GROSS } \\
\text { Residential } \\
\text { Commercial } \\
\text { Industrial }\end{array}$ & $\begin{array}{r}1284.4 \\
31.1 \\
11.6 \\
62.3\end{array}$ & $\begin{array}{r}30.0 \\
21.9 \\
2.4 \\
5.4\end{array}$ & $\begin{array}{r}290.8 \\
15.7 \\
32.8 \\
94.3\end{array}$ & $\begin{array}{r}125.4 \\
0.0 \\
0.0 \\
0.5\end{array}$ & $\begin{array}{r}241.3 \\
118.2 \\
76.7 \\
46.5\end{array}$ \\
\hline Percentages & 74 & 2 & 17 & 7 & \\
\hline
\end{tabular}

*Excluding nuclear and hydro electricity, coking coal and petroleum coke, and other petroleum products "not used as fuels. 
Type Number

coal mines

Natural gas (Iiq.)

Natural gas wells

crude oil wells
Units

0 thousand tons

2,133 thousand bol

33,857 million cu. ft.

32,695 thousand $\mathrm{bbl}$
Trillion

Btu

0

8. 6

37

189.6

IV. GEOLOGY

Florida is entirely underlain by Cretaceous to Recent unconsolidated sands and lithified carbonates. There are two areas in Florida where the sedimentary sequence attains depths great enough to serve as hydrothermal reservoirs: (a) West Florida Panhandle, and (b) Southern Florida. Sediments in these areas thicken in a wedge off the Peninsula Arch. In the Florida Panhandle, clastic sediments increase in depth towards the west from about $5,000 \mathrm{ft}$. to over 10,000 ft. Good aquifers, such as the Tuscaloosa and Smackover Formations (sands with moderate permeabilities), are found at depth in this region. Locally the geothermal gradient exceeds $1.6^{\circ} \mathrm{F} / 100 \mathrm{ft}$.

The remainder of Florida consists premarily of marine deposits such as limestone and dolomite. These deposits thicken southward from about 4,000 ft. to more than 20,000 ft. Gradients in central and southern Florida are below normal in the near surface and little is known about gradients and temperatures at depth. Estimated. temperatures from shallow gradients indicate central Florida may have temperatures of $120^{\circ} \mathrm{F}$ to over $212^{\circ} \mathrm{F}$ and southern Florida may have temperatures in excess of $300^{\circ} \mathrm{F}$ at depth.

V. RESOURCE DATA

1. FIORIDA PANHANDLE

Type aquifer: clastic sediments Area: 13,000 sq. mi. Depth: 5,000 to 20,000 Et. Avg. thickness:

Porosity: Transmissivity:

Water temperature: $120^{\circ} \mathrm{F}$ to $300^{\circ} \mathrm{F}$

Recharge rate:

Estimate of water stored in aquifer:

Estimate of energy content in water:

$1.5 \times 10^{14}$ cu. ft. In excess of 500 : $x$ $10^{15} \mathrm{Btu}^{\dagger}$ 
2. CENTRAL FLORIDA

Type aquifer: limestone or dolomite Area: 17,600 sq. mi. Depth: 4,000 to $15,000 \mathrm{ft}$. Avg. thickness:

Porosity: $\quad$ Transmissivity:

Water temperature: $120^{\circ} \mathrm{F}$ to $212^{\circ} \mathrm{F}$

Recharge rate:

Estimate of water stored in aquifer:

$2.1 \times 10^{14} \mathrm{cu} . \mathrm{ft}$.

Estimate of energy content in water: $600^{+} \times 10^{15} \mathrm{Btu}^{+}$

3. SOUTHERN FLORIDA

Type aquifer: limestone or dolomite Area: 11,800 sq. mi. Depth: 15,000 to 25,000 ft. Avg. thickness:

Porosity:

Transmissivity:

Water temperature: $212{ }^{\circ} \mathrm{F}$ to $300^{\circ} \circ \mathrm{F}$

Recharge rate:

Estimate of water stored in aquifer: $4.14 \times 10^{14} \mathrm{cu}$. ft.

Estimate of energy content in water: $2,000^{+} \times 10^{15} \mathrm{Btu}^{\dagger}$

tAbove $120^{\circ} \mathrm{F}$, references to $90^{\circ} \mathrm{F}$; $10 \%$ porosity assumed, about 4.5 times this amount in rock.

VI. GEOTHERMAL ACTIVITY

Request for technical assistance, City of Gainesville; Ltr. to APL/JHU 24 January 1980.

VII. LEGAL ACTIVITIES

None at present.

VIII. CONTACTS

1. Department of Natural Resources, 903 West Tennessee St., Tallahassee, FL 32304, Charles W. Hendry, Jr., Chief, Bureau of Geology, (904) 488-4191.

2. State Energy Office, State of Florida, Department of Administration, Room 108, Collins Building, Tallahassee, FL 32304, William W. Goode, Jr., Energy Data and Policy Analysis Administrator, (904) 488-0855.

REFERENCES AND LIST OF SIGNIFICANT REPORTS

(1) R. S. Barnett, "Basement Structure of Florida and Its Tectonic Implications," Transactions of the Gulf Coast Association of Geological Societies, Vol. XXV, pp. 122139,1975 .

$$
\text { FL }-3
$$


(2) G. V. Wilson, "Early Differential Subsidence and Configuration of the Northern Gulf Coast Basin in Southeast Alabama and Northwestern Florida," Transactions of the Gulf Coast Association of Geological Societies, Vol. XXV, Pp. 196-206, 1975.

(3) "Directory of Florida Industries, 1978," Florida Chamber of Commerce, 1977.

(4) W. J. Toth, "Pre-Scenario Visit to Florida," APL/JHU QM-77-161, 28 Dec 1977.

(5) "Geothermal Energy and the Eastern U.S., A Scenario for Geothermal Energy and Development, The Eastern Gulf Coast Plain," APL/JHU QM-77-129-3, Feb 1978.

(6) "Geothermal Resources of the Eastern United States," Gruy Federa1, DDE/ET/28373-T2, U.S. Department of Energy, Division of Geothermal Energy.

\section{COMMON REFERENCES}

$(C-1),(C-2),(C-3),(C-4),(C-5),(C-6)$, and $(C-7)$. 
GEOTHERMAL DATA SUMMARY SHEET

$$
\text { (cf. state Geothermal Fact sheet, Georgta) }
$$

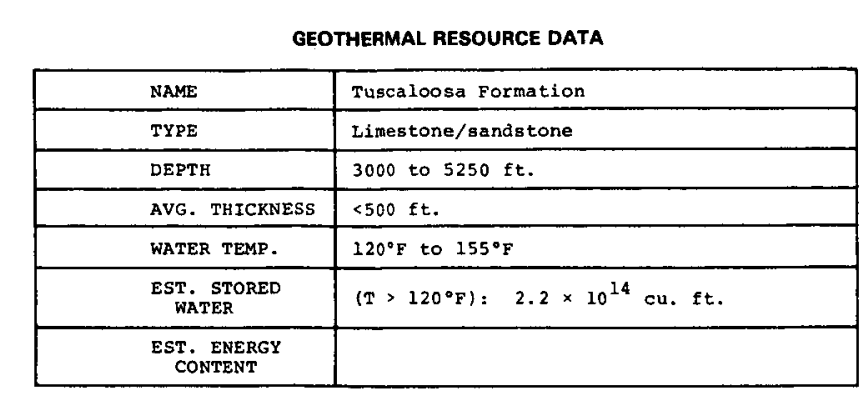

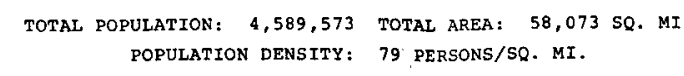

GEOTHERMAL OVERVIEW

The Atlantic Coastal Plain limestone and unconsolidated
sandstones reach thicknesses in excess of 5000 feet to the ces exist in these areas and may also occur in the northwestern part
of the state where deep parts of the Appalachian Basin

ENERGY RESOUREES-1975
ANNUAL PROOUCTION
An

\begin{tabular}{|c|c|c|c|}
\hline \\
\hline TYPE & NUMBER & STATUS & $10^{12} \mathrm{Btu}$ \\
\hline Coal mines & 0 & 0 thousand tons & 0 \\
\hline Natural Gas (1+1q.) & 0 & 0 thousand bbl & $0_{0}$ \\
\hline Natural Gas wel1s & $\circ$ & 0 million cu. ft & 0 \\
\hline Crude 011 we $11 \mathrm{~g}$ & 0 & 0 thousand $b b l$ & 0 \\
\hline
\end{tabular}

\section{ENERAY USE - 1975 110" BTUI}

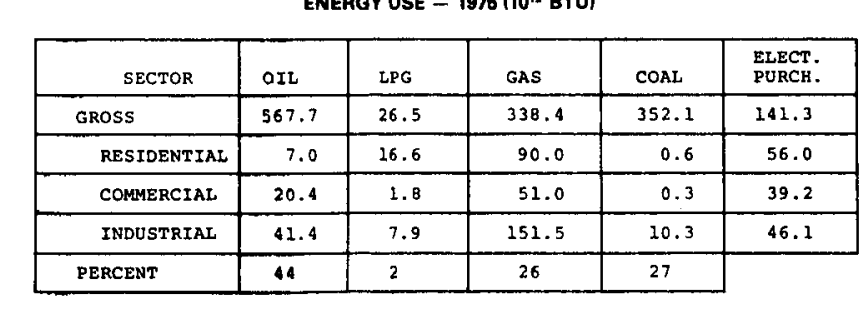

GEOTHERMAL ACTIVITIES

\begin{tabular}{|c|c|}
\hline CURREAT USES & 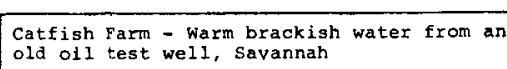 \\
\hline $\begin{array}{l}\text { RECENT OR CURBENT } \\
\text { STTODES }\end{array}$ & 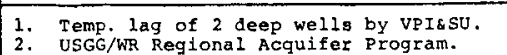 \\
\hline PROPOSED STUDIES & 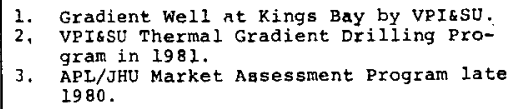 \\
\hline LEGAL ACTIVITIES & 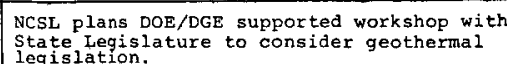 \\
\hline
\end{tabular}

GEORGIA

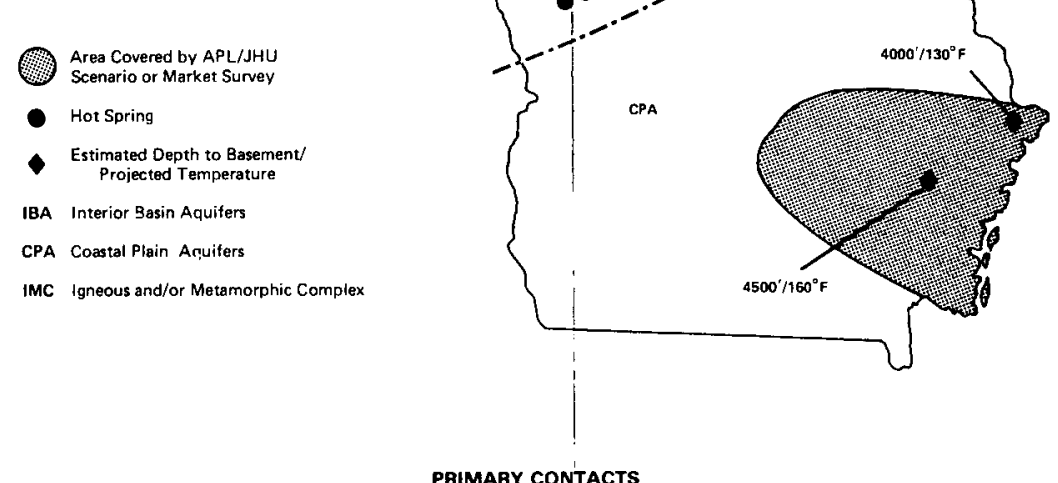

OFPICE OF ENERGY RESOURCES: Mark Zwecker, Di rector (404) 656-51)

\begin{tabular}{|c|c|}
\hline OFF FCE OF ENERGY RESOURCBS: & Mark Zweeker, Di rector (404) 656-5176 \\
\hline ENERGY FACLLITY SITING: & Chare H. Bonham (404) $656-5176$ \\
\hline COMPREHENSIVE LAND USE PLANNING: & Larry Gess (coordinator) (4004) 656-39332 \\
\hline 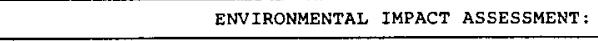 & Chuck Badger (404) $656-3858$ \\
\hline PUBLIC UTILITY REGULATION: & 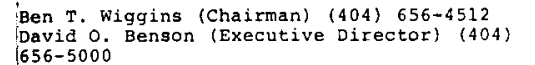 \\
\hline (STAAE) INDUSTRY COMMITTEE: & 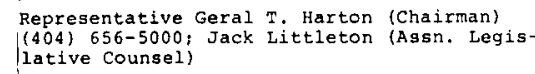 \\
\hline (STARE) PLANWTING AND COMMUNITY AFFAIRS COMMITTEE: & 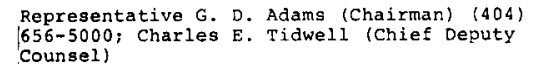 \\
\hline 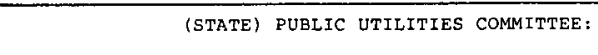 & 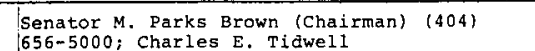 \\
\hline STATE) CONSUMER AFFAIRS & 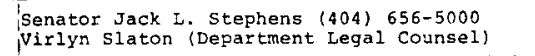 \\
\hline LECISLATIVE & 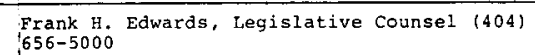 \\
\hline
\end{tabular}

LEGISLATIVE CONTACTS

\begin{tabular}{|c|c|}
\hline 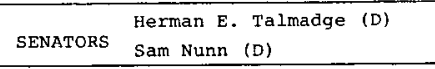 & GOVERNOR George susbee (D) \\
\hline $\begin{array}{l}\text { CONGRESSSEN (Dist.) } \\
\quad 1-\text { Roland Bo Ginn (D) }\end{array}$ & \\
\hline $\begin{array}{l}2-\text { Charles } \mathrm{F} \text {. Hatcher (D) } \\
8-\mathrm{D} \text { Billy Lee Evans (D) }\end{array}$ & \\
\hline
\end{tabular}


State Geothermal Fact sheet

\section{GEORGIA}

I. DEMOGRAPHIC INFORMATION (1970) (C-4)

TOTAL STATE

Population: 4,589,573 Area: $58,073 \mathrm{sq} \cdot \mathrm{mi}$. Density: 79 per sq. mi. GEOTHERMAL RESOURCE AREA

Population: 626,892 Area: $15,131 \mathrm{sq} \cdot \mathrm{mi}$. Density: 41 per sq. mi.

II. ENERGY CONSUMPTION* (1975) (C-7)

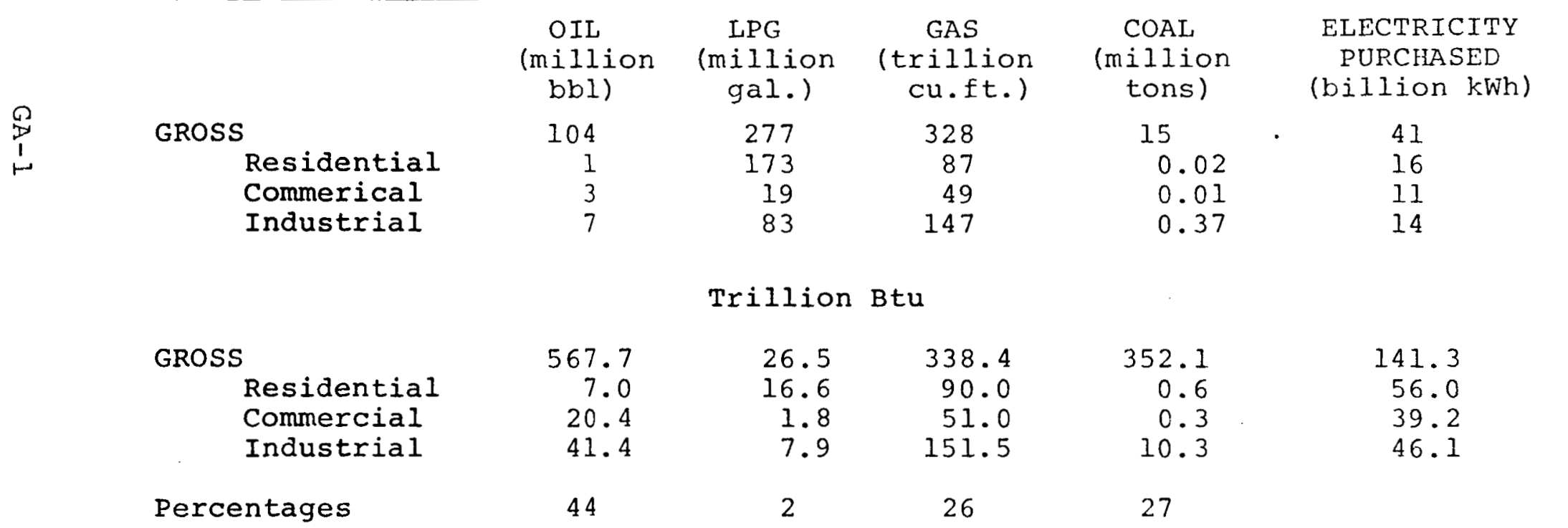

*Excluding nuclear and hyaro electricity, coking coal and petroleum coke, and other petroleum products not used as fuels. 
Type Number

Coal mines

Natural gas (liq.)

Natural gas wells

Crude oil wells

\section{0}

0

0

0
Units

0 thousand tons

0 thousand $\mathrm{bbl}$

0 million cu. ft.

0 thousand $\mathrm{bbl}$
Trillion

Btu

0
0
0
0

IV. GEOIOGY

The southeastern half of Georgia is underlain by largely unconsolidated, water-rich sediments of the Atlantic and Gulf Coastal Plain. Crystalline rocks of the Piedmont and Blue Ridge underlie most of the northern half of the state. However a narrow belt of folded Paleozoic sedimentary rocks occurs in the northwest corner. The Cretaceous to Pleistocene sediments of the coastal plain consist of clastic and carbonate rocks that occur in a southeastward thickening wedge. These sediments attain a depth of over $4000 \mathrm{ft}$. near the coast in the center of the Southeast Georgia Embayment. This embayment like the Salisbury Embayment in Maryland is a broad structural depression and it lies between two large uplifts. It is bounded by the Peninsula Arch in Florida and the Cape Fear Arch in South Carolina. A region of high geothermal gradients $\left(>2.0^{\circ} \mathrm{F} / 100 \mathrm{ft}.\right)$ coincides with this embayment.

$\mathrm{V}$. RESOURCE DATA

The coastal plains are the most attractive areas in Georgia for the existence of hydrothermal resources. The Cretaceous sands (Tuscaloosa Formation) are the deepest units that may contain extractable water between $120^{\circ}$ and $160^{\circ} \mathrm{F}$ although the shallower limestone units may have higher permeabilities.

Number of resource areas: 1 Type of resource: moderate temperature hydrothermal Type aquifer: limestone Area: 15,000 sq. mi. Porosity: $10 \%$ (est) Transmissivity: To be determined Avg. depth: 3000 to 5250 ft. Avg. thickness: Avg. water temperature: $120^{\circ}$ to $155^{\circ} \mathrm{F}$ Total dissolved solids: To be determined Recharge rate: To be determined
Eștimated water volume in aquifer $\left(T>120^{\circ} \mathrm{F}\right): 2.2 \times 10^{14} \mathrm{cu}$. ft. Estimated (extractable) energy content $\left(T>120^{\circ} \mathrm{F}\right):>20$ quads

VI. GEOTHERMAL ACTIVITY

Current use: Warm, brackish water from oil test well used to grow catfish - near Savannah. 
Recent activity: 1. Temperature logs of two existing deep wells made by VPI\&SU.

2. USGS/WR Regional Aquifer Program (continuing program beginning in 1980).

Planned activity: 1. Gradient test well at Kings Bay (U.S. Naval Base) in late 1980 by VPI\&SU.

2. VPI\&SU $1000 \mathrm{ft}$. thermal gradient drilling program to begin in 1981 .

3. APL/JHU Market Assessment Program to begin in late 1980.

VII. LEGAL ACTIVITIES

1. NCSL plans DOE/DGE workshop to consider geothermal legislation.

VIII. CONTACTS

1. Office of Energy Resources, Rm. 615, 270 Washington Street, S.W., Atlanta, GA, 30334, Mark Zwecker, Director, (404) 656-5176.

2. Energy Facility Siting, State Energy Office, 7 Hunter St., Rm. 145, Atlanta, GA 30334, Chart H. Bonham, Deputy Director, (404) 656-5176.

3. Comprehensive Land Use Planning, Office of Planning and Budget, 270 washington St., Atlanta, GA 30334, Larry Gess, Coordinator of Divisional Planning, (404) 656-3832.

4. Coastal Zone Management, Larry Gess (see Item 3 above).

5. Environmental Impact Assessments, Office of Planning and Budget, Chuck Badger, Administrator, State Clearinghouse (see Item 3), (404) 656-3858.

6. Public Utility Regulation, Public Services Commission, 244 Washington, S.W., Atlanta, GA 30334, Ben T. Wiggins, Chairman (404) 656-4512; David O. Benson, Executive Director, (404) 656-4539.

7. Legislative Energy Related Committees, State Capitol, Atlanta, GA 30334, (404) 656-5000.

a. Industry Committee, House of Representatives Representative Gerald T. Horton, Chairman; Jack Littleton, Asst. Legislative Counsel. 


\author{
b. State Planning \& Community Affairs Committee, \\ House of Representatives \\ Representative G. D. Adams, Chairman; \\ Charles E: Tidwell, Chief Deputy Counsel. \\ c. Public Utilities Committee, state Senate \\ Senator M. Parks Brown, Chairman; \\ Charles E. Tidwell, Chief Deputy Legislative \\ Counsel. \\ d. Consumer Affairs Committee, state Senate, \\ Senator Jack L. Stephens \\ Virlyn Slaton, Deputy Legislative Counsel \\ 8. Legislative Services, Office of Legislative Counsel, \\ 316 State Capitol, Atlanta, GA 30334, Frank H. Edwards, \\ Legislative Counsel, (404) 656-5000. \\ REFERENCES AND LIST OF SIGNIFICANT REPORTS
}

(1) J. W. Antoine and V. J. Henery, "Seismic Refraction Study of Shallow Part of Continental shelf off the Georgia Coast," A.A.P.G. Bull., Vol. 49, pp.601-609, 1965 .

(2) C. W. Cooke, "Geology of the Coastal Plain of Georgia," U.S.G.S. Bull. 941, p. 121, 1943.

(3) "Energy and U.S. Agriculture: 1974 Data Base," Vol. 1, Federal Energy Administration, 1976.

(4) S. M. Herrick and R. C. Vorhis, "Subsurface Geology of the Georgia Coastal Plain," Georgia Geol. Survey Information Circ. 25, 1963.

(5) J. C. Maher and.E. R. Appiin, "Geologic Framework and Petroleum Potential of the Atlantic Coastal Plain and Continental Shelf," U.S.G.S. Professional Paper 659, 1971 .

(6) P. I. Rice, "Energy Conditions in the South," ORNL/TM5568, Oak Ridge National Laboratory, 1976.

(7) M. A. Warren, "Artesian Water in Southeastern Georgia," Georgia Geol. Survey, Bull. 49, 1944.

(8) "Evaluation and Targeting of Geothermal Energy Resources in the Southeastern United States, Progress Report October 1, 1978 - March 30, 1979," VPI-SU-5648-5, VPI\&SU, Blacksburg, VA. 
(9) "Evaluation and Targeting of Geothermal Energy Resources in the Southeastern United States, Progress Report July 1, 1979 to September 30, 1979," VPI\&SU-78ET-27001-7, VPI\&SU, Blacksburg, VA.

(10) "Visit to Georgia State Survey and U.S.G.S. Resources Office, Atlanta and the Georgia State Energy Office," APL/JHU QM-77-010, 31 Jan 1977.

(11) "Discussion of Geothermal Energy with the Georgia Power Company," APL/JHU QM-79-128, 8 Jun 1979.

(12) "Visit to U.S.G.S. Water Resources, Atlanta," APL/JHU QM-79-130, 8 Jun 1979 .

(13) "Visit to Atlanta," APL/JHU QM-80-107, 30 Jun 1980.

(14) "Geothermal Resources of the Eastern United States," Gruy Federal Inc., Report for the Department of Energy, $\mathrm{DOE} / \mathrm{ET} / 288373-\mathrm{T} 2$.

COMMON REFERENCES

$$
(C-1),(c-4),(c-6) \text {, and }(C-7) \text {. }
$$




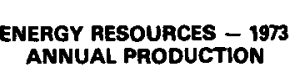

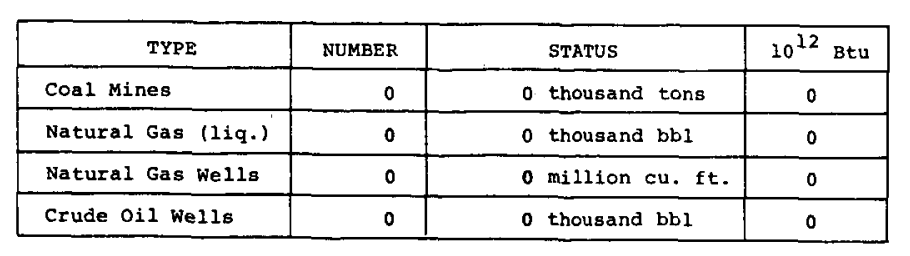

\section{HAWAII}

GEOTHERMAL DATA SUMMARY SHEET

TORAL POPULAATION: 768,561 TORAL AREA; 6 6,425 Se. MI.

POPULARTION DENSITY: 120 PERSONS/SQ. MI.

GEOTHERMAL OVERVIEW

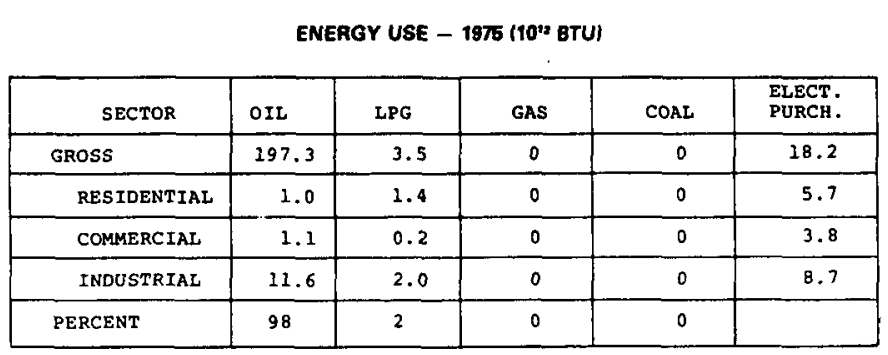

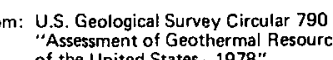

0 knowi<smiles>C1C[As]C1</smiles>

Kevcir

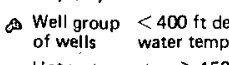

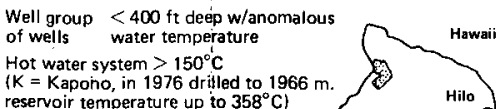

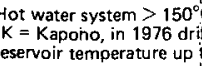

ar 790

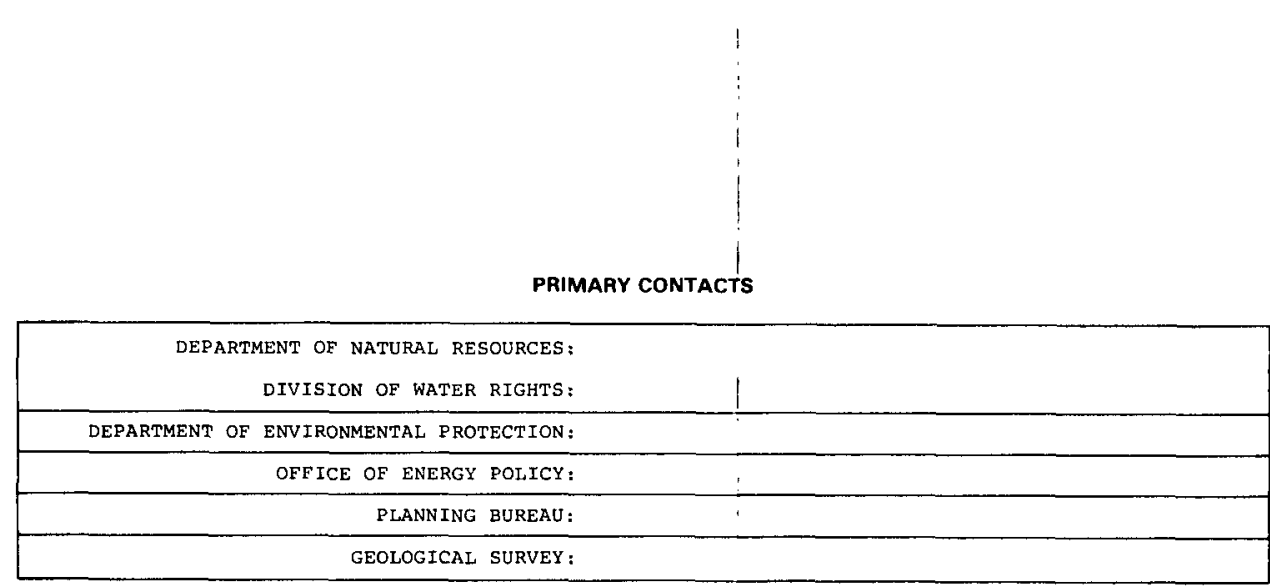

GEOTHERMAL ACTVITIES

\begin{tabular}{|l|l|}
\hline CURRENT USES & \\
\hline RECENT OR CURRENT & \\
\hline STrDDES & \\
\hline PROPOSBD STUDTES & \\
\hline LEGAL ACTIVITTES & \\
\hline
\end{tabular}

LEGISLATIVE CONTACTS

\begin{tabular}{|c|c|}
\hline $\begin{array}{c}\text { SENARORS } \\
\text { Daniel Inouye (D) } \\
\text { Spark M. Matsunaga (D) }\end{array}$ & GOVERNOR George R. Ariyoshi (D) \\
\hline CONGRESSNEN (DIST.) \\
$\begin{array}{c}\text { 1- Ceci1 Hafte1 (D) } \\
\text { 2- Danie1 K. Akaka (D) }\end{array}$ & \\
\hline & \\
& \\
\hline
\end{tabular}



III. STATE FUEL PRODUCTION (1973) (C-6)

Type Number Units Btu

Coal mines

Natural gas (liq.)

Natural gas wells

Crude oil wells
0

0

0

0

0 thousand tons

0 thousand $\mathrm{bbl}$

0 million cu. ft.

0 thousand $\mathrm{bbl}$

Trillion

Btu

0

0

0

0

IV. GEOLOGY

The State of Hawaii occupies a series of Tertiary to Recent volcanic islands in the South Pacific. These volcanic centers are aligned and become younger from northwest to southeast. Hydrothermal convective systems containing water above $150^{\circ} \mathrm{C}$ are known only on the main island of Hawaii.

V. RESOURCE DATA

To be determined.

VI. GEOTHERMAL ACTIVITY

To be determined.

VII. LEGAL ACTIVITIES

To be determined.

VIII. CONTACTS

No data.

REFERENCES AND LIST OF SIGNIFICANT REPORTS

Common references only, see below.

COMMON REFERENCES

$(C-4),(C-6)$, and $(C-7)$. 

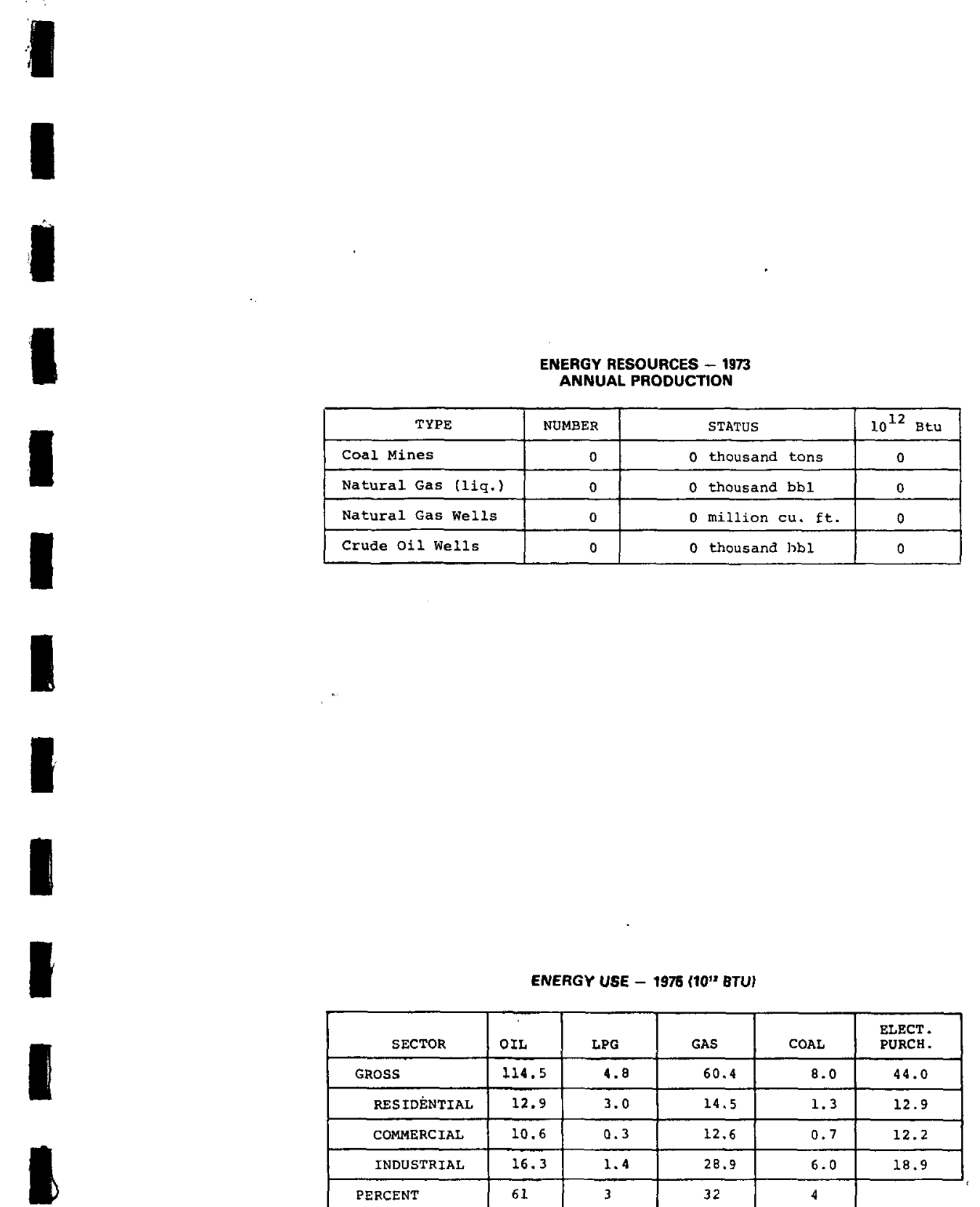

GEOTHERMAL ACTVITIES

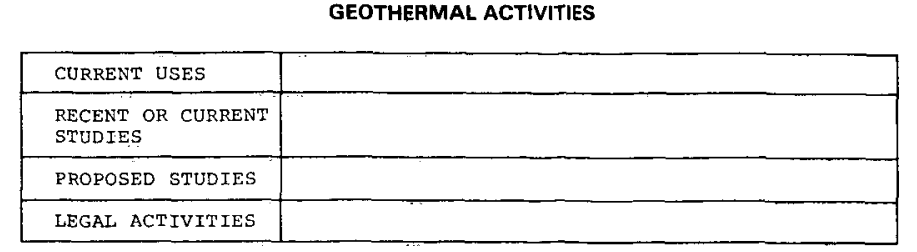

GEOTHERMAL DATA SUMMARY SHEET

$$
\text { (cf. state Geotherma1 Fact sheet, Idaho) }
$$

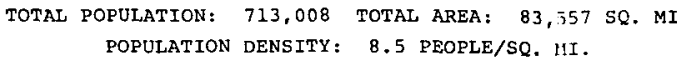

GEOTHERMAL OVERVIEW

Large volumes of young volcanic and intrusive rocks make develooment. Nine KGPAs have been desiglor eral moderate temperature reservoirs have been confirmed
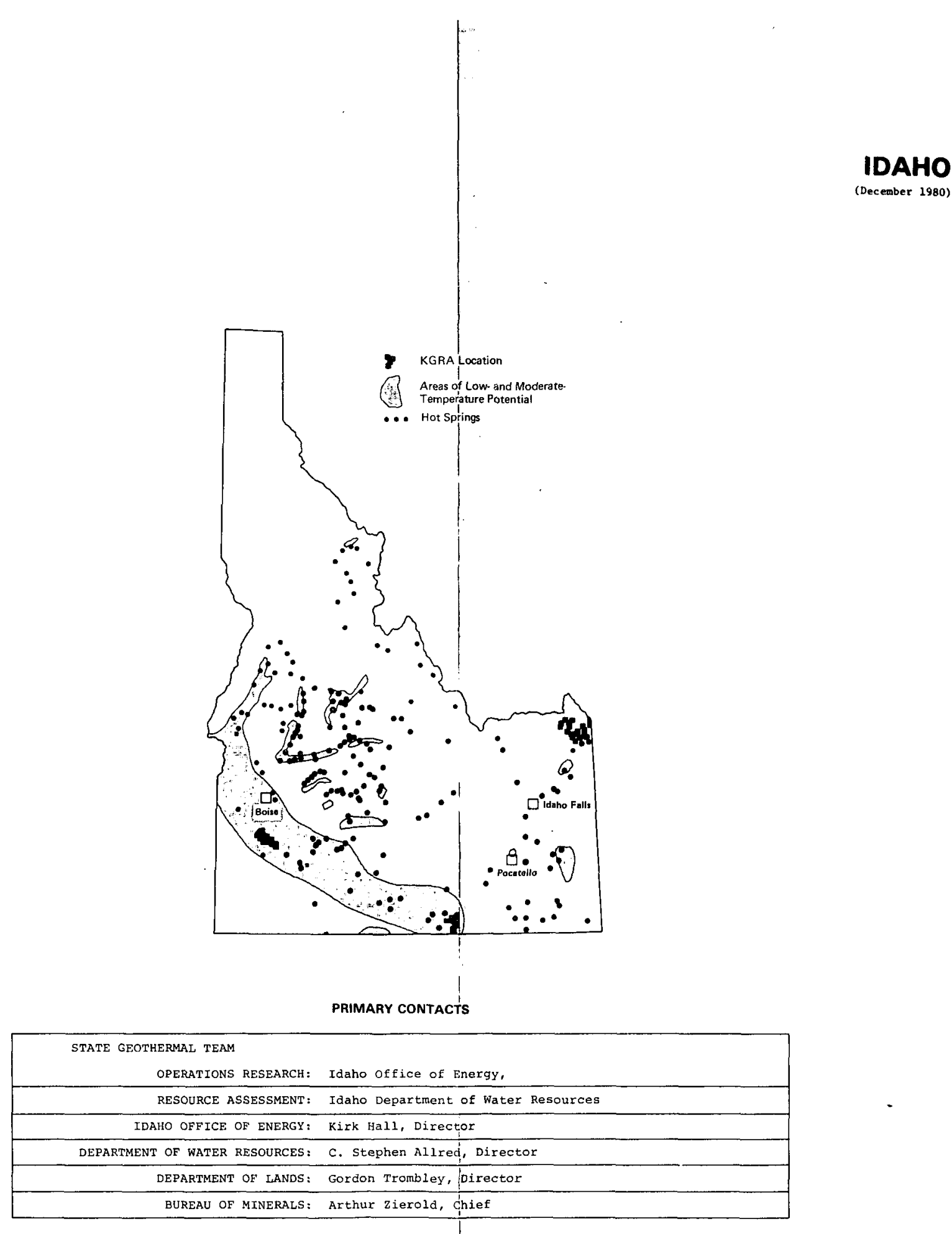

LEGILLATVE CONTACTS

\begin{tabular}{|c|c|}
\hline $\begin{array}{l}\text { SENATORS } \begin{array}{l}\text { Frank Church (D) } \\
\text { James A. McClure (R) }\end{array} \\
\text { Jal }\end{array}$ & GOVERNOR John V. Evans (D) \\
\hline $\begin{array}{l}\text { CoNGRESSNAN (DIST.) } \\
\text { 1- Larry Craig (D) } \\
\text { 2- George Hansen (R) }\end{array}$ & \\
\hline
\end{tabular}



Type Number

Coal mines

Natural gas (liq.)

Natural gas wells

Crude oil wells
Units

Trillion

Btu.

0 thousand tons $\quad 0$

0 thousand bbl

0 million cu. ft.

0 thousand bbl
0

\section{GEOLOGY}

Five physiographic provinces occur in Idaho: the snake River Plain, the Northern Rocky Mountains, the Basin and Range, the Middle Rocky Mountains, and the Columbia Plateau. A number of shallow, moderate and low temperature resources exists and are associated with faulting along the snake River Plain and the Idaho Batholith of the Northern Rockies. The deeper, relatively undrilled Snake River Plains downwarp may contain high temperature resources that are effectively hidden from surface exploration by the high flow rate cold water of the Snake plains aquifer. Industry is focusing on the high temperature fluids from the snake River Plain and from a portion of the Basin and range in southeastern Idaho.

V. RESOURCE DATA

No high temperature resources have been confirmed but fourteen areas are considered to have good potential. Three low and moderate resources have been confirmed and many prospects exist.

VI. GEOTHERMAL ACTIVITY

Geothermal leasing totals 373,000 acres, all but about 60,000 on federal lands.

Two PoNs were awarded (1978) in Idaho: one for space heating commercial buildings and homes in Boise, one in Rexburg for municipal space heating and industrial food processing.

One PRDA supported study was conducted in 1979 to examine the use of hydrothermal energy in livestock meat and feed production and in facilities for potato processing and methane gas production.

A 5 MW binary geothermal electric plant is scheduled to be on line in 1980 as the culmination of the DOE sponsored Raft River power production project. In addition, experiments in agriculture, aquaculture, fluidized bed drying, air conditioning, and heat exchanger materials are being performed. 
Various development plans have been prepared for 32 sites or areas as part of the DOE geothermal operations research project.

\section{LEGAI ACTIVITIES}

In 1972 the Idaho Geothermal Resources Act was passed. This act gave regulating authority for all geothermal development to the Department of Water Resources.

In 1979 two bills were enacted that authorize cities and counties to operate geothermal systems. Cities are also authorized to issue revenue bonds to finance construction costs of such systems.

VIII. CONTACTS

1. State Geothermal Team:

a. Operations Research, Idaho Office of Energy;

b. Resource Assessment, Idaho Department of Water Resources;

c. Idaho Office of Energy, Kirk Hall, Director.

2. Department of Water Resources, C. Stephen Allred, Director.

3. Department of Lands, Gordon Trombley, Director.

4. Bureau of Minerals, Arthur Zierold, Chief.

REFERENCES AND LIST OF SIGNIFICANT REPORTS

(1) "Idaho Hydrothermäl Commercialization Baseline," EG\&G Idaho, Inc., Apr 1979.

(2) David V. McClain, "Geothermal Energy in Idaho: Site Data Base and Development Status," Geo-Heat Utilization Center, Klamath Falls, OR, JuI 1979.

COMMON REFERENCES

$(C-4),(C-6)$, and $(C-7)$. 

Type

Coal mines

Natural gas (liq.)

Natural gas wells

crude oil wells
Number

$$
55
$$

36

24,309
Units

$$
\begin{aligned}
& 61,575 \text { thousand tons } \\
& 8,650 \text { thousand bbl } \\
& 1,638 \text { million cu. ft. } \\
& 30,669 \text { thousand bbl }
\end{aligned}
$$

Trillion Btu.

$1,402.7$

34.7

1.8

IV. GEOLOGY

Illinois is underlain by Paleozoic sedimentary rocks that were deposited on the Precambrian basement. The dominant geologic feature is the Illinois Basin centered in the southeastern part of the state, where up to $14,000 \mathrm{ft}$. of sediments have been deposited. This basin is separated from the Appalachian Basin to the east by a basement high (the Cincinnati Arch) and to the north from the Michigan Basin by the Kankakee Arch. The Cenozoic Gulf Coastal Plain sediments overlie the Paleozoic sedimentary rocks to the south.

Surficial deposits of Pleistocene glacial till overlie the sedimentary rocks throughout most of the state and provide an ample fresh water supply. Water also occurs in the older sedimentary rocks of the Paleozoic Illinois Basin; however, it becomes more saline, hotter, and harder to extract with depth. In the deeper parts of the basin, the rocks become more indurated and secondary permeability becomes more important in the circulation of water. Along the southern border of the Illinois Basin lies the Rough Creek-Kentucky Fault zone. This major fault zone appears to have had a significant control on the deposition and deformation of the Paleozoic sediments. Water appears to circulate along this fault zone between permeable horizons.

V.

RESOURCE DATA

Hydrologic data are available for much of the deep aquifer systems in the Illinois Basin. The knox Formation, which is locally highly permeable due to solutioning (caverns), attains depths of about 10,000 ft. The Mt. Simon Formation and other basal sandstone do exhibit significant hydraulic heads in the deeper parts of the basin. This water is known to be hot since many oil and gas wells in this area have indicated gradients of greater than $1.8^{\circ} \mathrm{F} /$ $100 \mathrm{ft}$. Temperatures in excess of $200^{\circ} \mathrm{F}$ can therefore be expected where these high gradients coincide with the deeper parts of the basin. 
VI. GEOTHERMAL ACTIVITY

Recent studies: $\quad 1$. Illinois state Geologic Survey Study.

2. DOE/DGE Gruy Federal study $(\mathrm{C}-16)$.

3. LASL performing initial planning studies for geothermal exploration.

VII. LEGAL ACTIVITIES

None at present.

VIII. CONTACTS

1. Department of Conservation, Anthony T. Dean, Director, (217) 782-6302.

2. Water Survey, Dept. of Registration \& Education, William C. Ackermann, Chief, (217) 333-2210.

3. Environmental Protection Agency, William L. Blaser, Director, (217) 782-3397.

4. Division of Energy, Dept. of Business \& Economic Development, Sidney M. Marder Director, (217) 782-5784.

5. Energy Resources Commission, Hon. Adeline J. Geo-Karis, Chairman, (217) 782-8097.

6. Jack A. Simon, Chief, (217) 344-1481.

REFERENCES AND LIST OF SIGNIFICANT REPORTS

Common references only, see below.

COMMON REFERENCES

$(C-4),(C-6),(C-7)$, and $(C-16)$. 
ENERQY RESOURCES - 9975
ANNUAL PROOUCTON

\begin{tabular}{|c|c|c|c|}
\hline \multicolumn{4}{|c|}{ 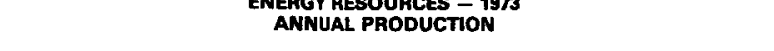 } \\
\hline TYPE & NUMBgR & starus & $20^{12} \mathrm{Btu}$ \\
\hline Coal Mines & 39 & 25,252 thousand tons & 585.8 \\
\hline Natural Gas (1iq.) & & 0 thousand bb1 & 0 \\
\hline Naturat Gas we1 & 206 & 276 millition cu. ft. & 0.3 \\
\hline Crude 0i1 we $11 \mathrm{~s}$ & 4,323 & 5,312 thousand bbl & 30.8 \\
\hline
\end{tabular}

\section{ENERQY USE - 1956 110" BTU}

\begin{tabular}{|c|c|c|c|c|c|}
\hline secror & ort & LPG & GAS & COAL & 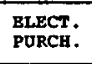 \\
\hline Gross & 649.0 & 67.3 & 997.2 & 1103.8 & 162.2 \\
\hline RESIDERNTAR & 78.8 & 28.3 & 168.1 & 10.2 & 54.6 \\
\hline Comararcial & 62.3 & 3.2 & 72.8 & 5.5 & 32.5 \\
\hline INDUSTRRAL & 82.7 & 15.6 & 235.2 & 91.9 & 75.0 \\
\hline $\mathrm{RCE}$ & 28 & 2 & 22 & 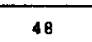 & \\
\hline
\end{tabular}

GeOTHEPMAL ACTVTIIS

\begin{tabular}{|c|c|}
\hline CURERT USES & None \\
\hline $\begin{array}{l}\text { RECENT OR CURRENT } \\
\text { STUDIISS }\end{array}$ & 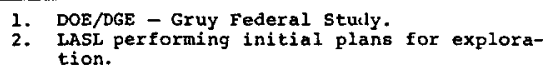 \\
\hline PROPOSED STUDIBS & None \\
\hline LEGAL ACrIVITIIES & None \\
\hline
\end{tabular}

INDIANA

GEOTHERMAL DATA SUMMARY SHEET

(cf. State Geothermal Fact Sheet, Indiana)

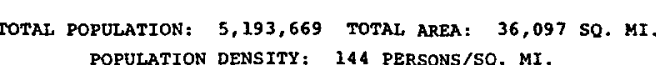

GEOTHERMAL OVERVIEW

A deep setimentary basin in the southwestern portion of
Ane state has potential as a hydrotherrmal resource and for the state has potential as a hydrothermal resource and for

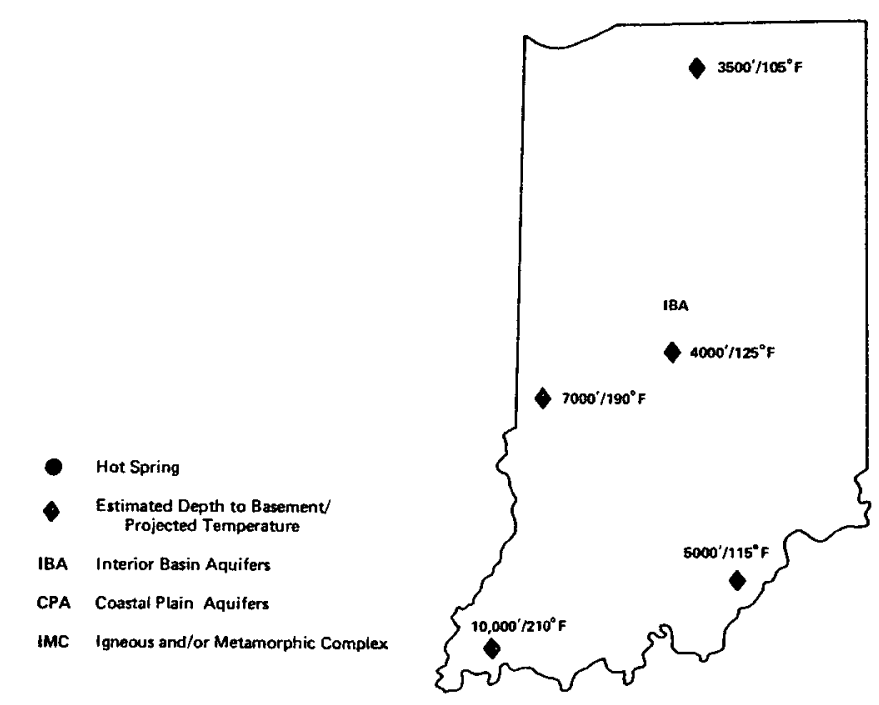

PRIMARY CONTACTS

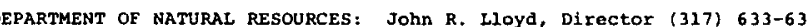

DIVISTON OF WARER RICHTS: Robere F. Fackson, Director

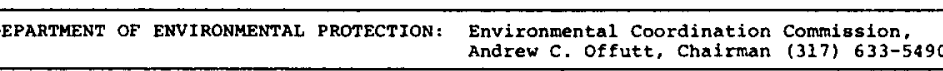

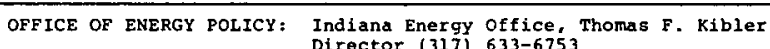

PLANNING BURER: State Planning Services, Eugene Waterstraat,

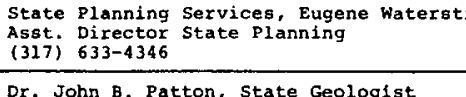

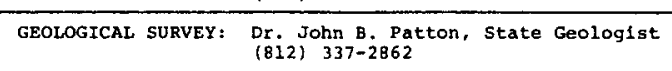

\begin{tabular}{|c|c|}
\hline \multicolumn{2}{|c|}{ LEGILATINE CONTACTS } \\
\hline $\begin{array}{lll}\text { SENATORS } & \begin{array}{l}\text { Birch Bayh (D) } \\
\text { Richard G. Lugar (R) }\end{array}\end{array}$ & GOVERNOR Robert OrF (R) \\
\hline CONGRESShEN (DIST.) & \\
\hline 1 - Adam Benjamin, Jr. (D) & 7 - John T. Myers (R) \\
\hline 2 - Floya J. Fithian (D) & $B$ - H. Joel Deckara $(R)$ \\
\hline 3 - John P. Hiler (R) & 9 - Lеe 月. Hamilton (D) \\
\hline 4-Danie1 R. Coats (R) & $10-$ Philip R. Sharp (D) \\
\hline $5-$ Elwood $\mathrm{H}$. Hilli is $(\mathrm{R})$ & 11 - Andrew Jacobs, Jr. (D) \\
\hline 6- David W. Evans (D) & \\
\hline
\end{tabular}



III. STATE FUEL PRODUCTION (1973) (C-6)

Type Number Units $\quad$ Btu

Coal mines

Natural gas (liq.)

Natural gas wells

Crude oil wells

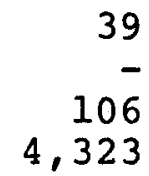

585.8

0

0.3

IV.

\section{GEOLOGY}

Indiana is underlain by Paleozoic sedimentary rocks that were deposited on the Precambrian basement. The dominant geologic feature is the Illinois Basin, centered in the southwestern tip of the state where up to $12,000 \mathrm{ft}$. of sediments have been deposited. This basin is separated from the Appalachian Basin to the east by a basement high (the Cincinnati Arch) and to the north from the Michigan Basin by the Kankakee Arch. The Cenozoic Gulf Coastal Plain sediments overlie the Paleozoic sedimentary rocks to the south.

Surficial deposits of Pleistocene glacial till overlie the sedimentary rocks throughout most of the state and provide an ample fresh water supply. Water also occurs in the older sedimentary rocks of the Paleozoic Illinois Basin; however, it becomes more saline, hotter, and harder to extract with depth. In the deeper parts of the basin, the rocks become more indurated and secondary permeability becomes more important in the circulation of water. The Rough Creek-Kentucky fault zone lies along the southern border of the Illinois Basin. This major fault zone appears to have had a significant control on the deposition and deformation of the Paleozoic sediments. Water appears to circulate along this fault zone between permeable horizons.

V. RESOURCE DATA

Most well temperature data from Indiana come from oil and gas exploration in and around the Illinois Basin. The thicker sequences of sediments occur in the southwestern parts of the state. At Bloomington, the sedimentary pile is about $5000 \mathrm{ft}$. thick and temperatures at i,ts base can be expected to be at least $130^{\circ} \mathrm{F}$ based on a gradient of $1.6^{\circ} \mathrm{F} / 100 \mathrm{ft}$. Near Evansville, where the sequence is about $10,000 \mathrm{ft}$. thick and gradients are at least $1.6^{\circ} \mathrm{F} / 100 \mathrm{ft}$. , temperatures on the order of $210^{\circ} \mathrm{F}$ may occur. 
THE JOHNS HOPKINS UNIVERSITY

APPLIED PHYSICS LABORATORY

LAUREL, MARYLAND

VI. GEOTHERMAL ACTIVITY

Recent studies: $\quad$ 1. DOE/DGE - Gruy Federal Study (C-16).

2. LASL performing initial plans for exploration.

VII. LEGAL ACTIVITIES

None at present.

VIII. CONTACTS

1. Department of Natural Resources, John R. Lloyd, Director, (317) 633-6344.

2. Division of Water Rights, Robert F. Jackson, Director, (317) 633-5267.

3. Environmental Coordination Commission, Andrew C. Offutt, Chairman, (317) 633-5490.

4. Indiana Energy office, Thomas F. Kibler, Director, (317) 633-6753.

5. State Planning Services, Eugene Waterstraat, Asst. Director State Planning, (317) 633-4346.

6. State Geologist, Dr. John B. Patton, (812) 337-2862.

REFERENCES AND LIST OF SIGNIFICANT REPORTS

Common references only, see below.

COMMON REFERENCES

$(c-4),(c-6),(c-7)$, and $(c-16)$. 
State Geothermal Fact sheet

IOWA

I. DEMOGRAPHIC INFORMATION (1970) (C-4)

TOTAL STATE

Population: 2,824,376 Area: 55,941 sq. mi. Density: 51 per sq. mi.

GEOTHERMAL RESOURCE AREA

Population:

Area:

sq. $\mathrm{mi}$.

Density:

per sq. mi.

II. ENERGY CONSUMPTION*

(1975)
OIL
(million
bbl)

$(\mathrm{C}-7)$

LPG

(million

GAS
(trillion
cu.ft.)

COAL

(million

tons)

ELECTRICITY

PURCHASED

GROSS

Residential

Commerical

55

488

302

351

94

4
2

Industrial

34
152

67
127

7

0.1

0.03

1.1

20

8

5
7

Trillion Btu

\section{GROSS \\ Residential \\ Commercial \\ Industrial}

Percentages

$\begin{array}{rr}46.7 & 362.7 \\ 28.9 & 97.4 \\ 3.2 & 69.1 \\ 14.5 & 131.2\end{array}$

5

$$
\begin{array}{r}
144.1 \\
1.5 \\
0.8 \\
27.1
\end{array}
$$$$
68.4
$$$$
28.1
$$$$
17.6
$$$$
22.7
$$

17

*Excluding nuclear and hydro electricity, coking coal and petroleum coke, and other petroleum products not used as fuels. 
III. STATE FUEL PRODUCTION (1973) (C-6)

Type

Coal mines

Natural gas (liq.)

Natural gas wells

Crude oil wells
Number

12

$-$

0

0
Units

601 thousand tons

0 thousand bbl

0 million cu. ft.

0 thousand bbl
Trillion

Btu

11.7

0

0

0

IV. GEOLOGY

To be supplied.

V. RESOURCE DATA

DOE/DGE Analysis of Eastern U.S. See $(C-16)$.

VI. GEOTHERMAI ACTIVITY

Recent studies: DOE/DGE Report, "Geothermal Resources of the Eastern U.S."

VII. LEGAL ACTIVITIES

To be determined.

VIII. CONTACTS

1. Energy Policy Council, Maurice Van Nostrand, Chairman, (515) 281-3428.

2. Office of Planning and Programming, Robert F. Tyson, Director, (515) 281-5888.

3. State Geologist, Dr. Stanely G. Grant, (319) 338-1173.

4. State Legislature Representatives:

a. State Senate: Sen. James Gallagher, Chairman, (515) 281-3048.

b. House of Rep: Rep. Mary O'Halloran, Chairman, (515) 281-3048. 
THE JOHNS HOPKINS UNIVERSITY

APPLIED PHYSICS LABORATORY

LAUREL, MARYLAND

\section{REFERENCES AND LIST OF SIGNIFICANT REPORTS}

Common references only, see below.

\section{COMMON REFERENCES}

$(C-4),(C-6),(C-7)$, and $(C-16)$. 
ENERGY YESOURCES - 1973
ANNUAL PROOUCTON

\begin{tabular}{|c|c|c|c|}
\hline TYPE & NUMBER & 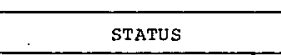 & $10^{12}$ Btu \\
\hline Coal Mines & 4 & 1,085 thousand tons & 26.4 \\
\hline Natural Gas (1iq.) & & 30,456 thousand $\mathrm{bb} 1$ & 122.8 \\
\hline Natural Gas we11s & 8,765 & 893,118 mini1ion cu. $\mathrm{ft}$ & 976.2 \\
\hline Crude oil wel1s & 41,520 & 66,227 thousand bb1 & 384.1 \\
\hline
\end{tabular}

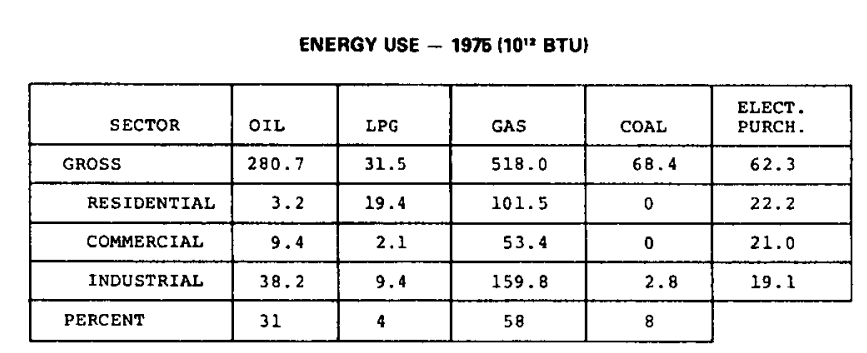

GEOTHERMAL ACTIVITIES

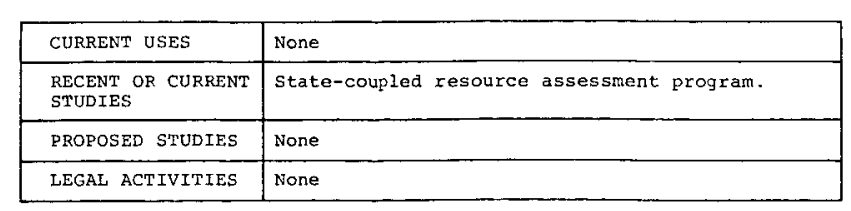

GEOTHERMAL DATA SUMMARY SHEET

$$
\text { (cf. State Geotherral pact sheet, Ransas) }
$$

FOTAL POPULATION: 2, 246,578 TOTAL AREA: 81,787 SQ. M.

GEOTHERMAL OVERVIEW

A sedimentary basin in the western portion of the state is
of modest depth and has normal temperature gradients.
KANSAS

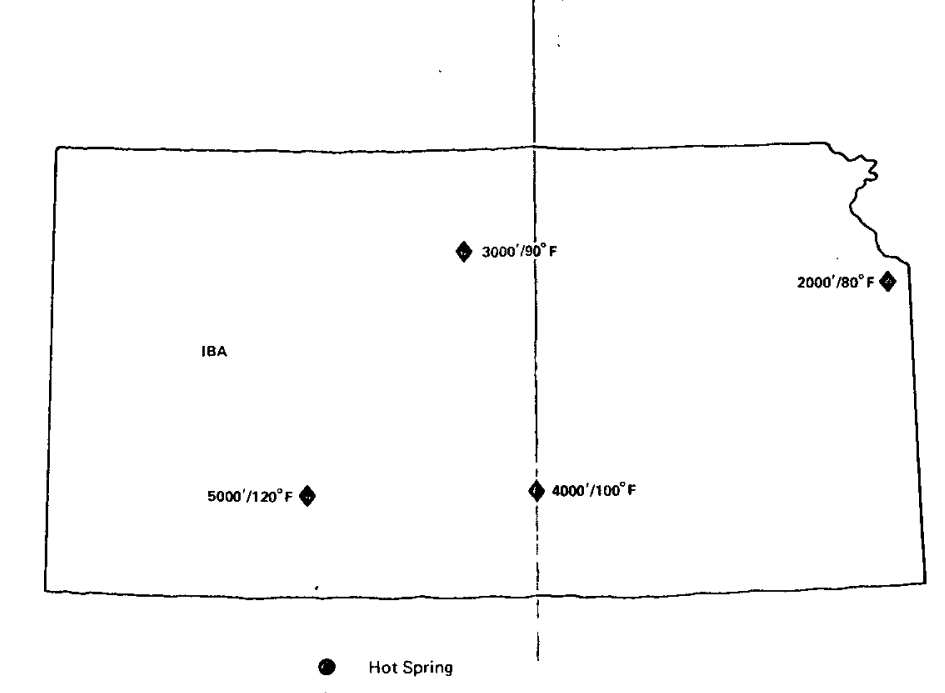

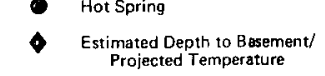

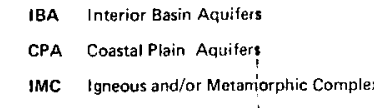

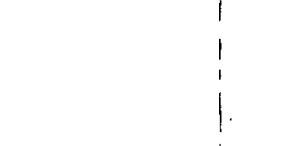

PRIMARY CONTÁCTS

DEPRRTMENT OF NATURAL RESOURCES:

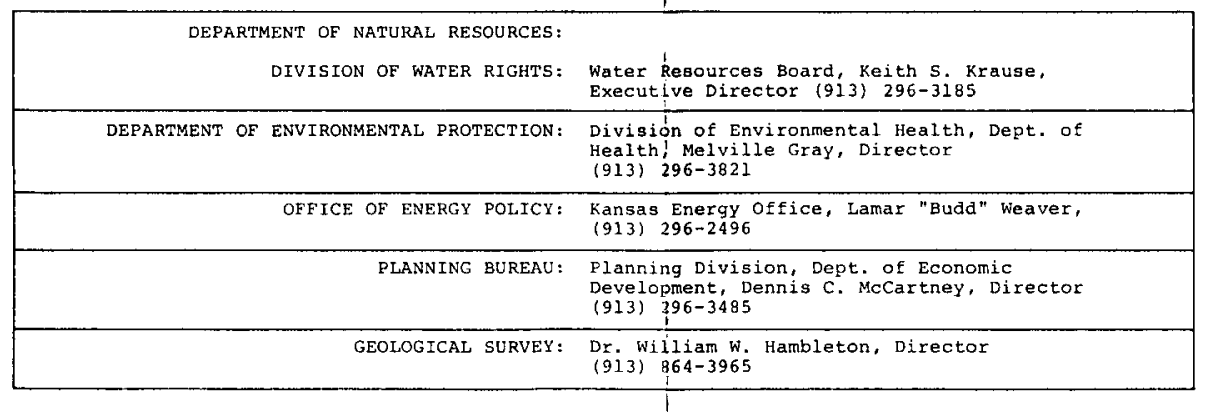

LEGILATIVE CONTACTS

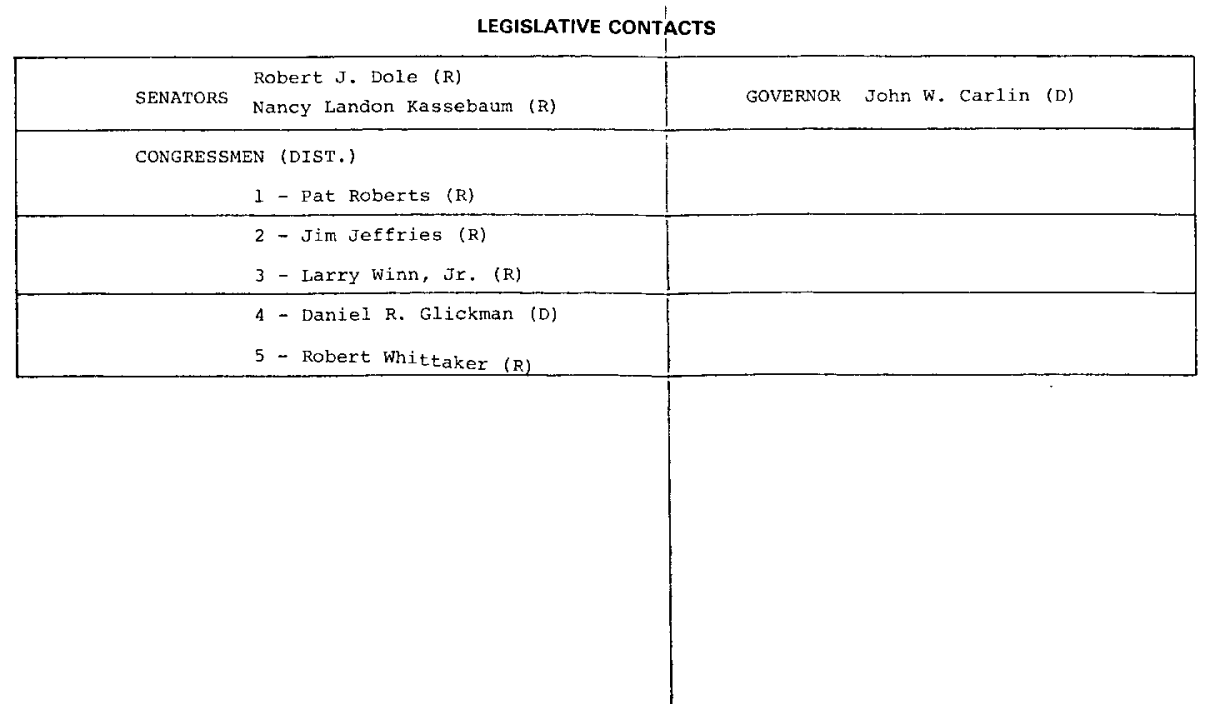


State Geothermal Fact sheet

KANSAS

I. DEMOGRAPHIC INFORMATION (1970) (C-4)

TOTAL STATE

Population: 2,246,578 Area: 81,787 sq. mi. Density:27.5 per sq. mi.

GEOTHERMAI RESOURCE AREA

Population:

Area: $\quad$ sq. mi. Density: per sq. mi.

II. ENERGY CONSUMPTION* (1975) (C-7)

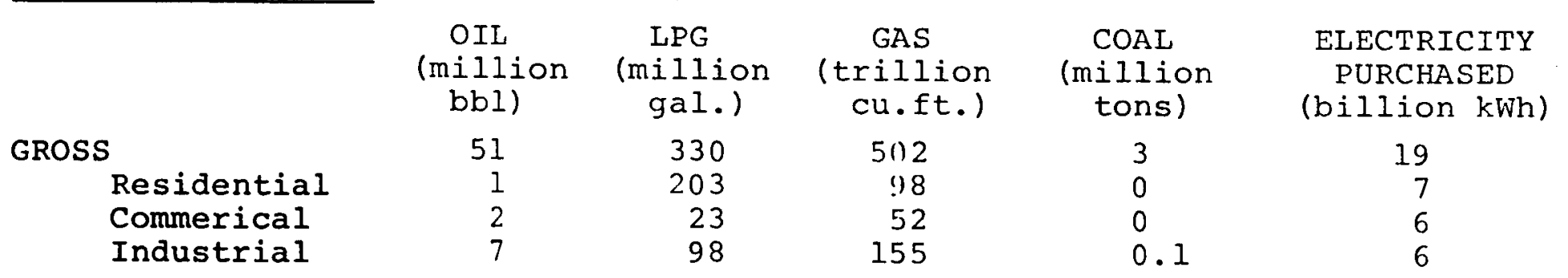

Trillion Btu

\section{GROSS \\ Residential \\ Commercial \\ Industrial}

Percentages

$$
\begin{array}{r}
280.7 \\
3.2 \\
9.4 \\
38.2
\end{array}
$$

31

$\begin{array}{rr}31.5 & 518.0 \\ 19.4 & 101.5 \\ 2.1 & 53.4 \\ 9.4 & 159.8\end{array}$

4

58

68.4
0
0
2.8

62.3

22.2

21.0

19.1

*Excluding nuclear and hydro electricity, coking coal and petroleum coke, and other petroleum products not used as fuels. 
III. STATE FUEL PRODUCTION (1973) (C-6)

Type Number Units Btu

Coal mines

Natural gas (liq.)

Natural gas wells

crude oil wells

\author{
$8, \frac{4}{-}$ \\ 41,520
}

1,085 thousand tons

30,456 thousand bbl
893,118 million cu. ft.

66,227 thousand bbl
26.4

122.8

976.2

384.1

IV. GEOLOGY

Kansas has three geologic forms of interest. The Nemaha uplift (anticline) is the end of the midcontinent rift. This faulted Precambrian intrusive mass enters the state in the northeast corner and progresses southwest, disappearing just before it reaches the oklahoma border about one-third of the way, going west. In the northwestern half of the state, the Cambridge Arch from Nebraska enters and becomes the Central Kansas uplift, followed by the Pratt anticline, which disappears before the border of oklahoma is reached. The direction of this second system is opposite to the Nemaha, i.e., southeastern. In the western part of the state there is a plateau (the Hugoton Embayment) before the basement drops into the Anadarko Basin that extends into Colorado. In the southwestern region of the state, the basement rock plunges to the Anadarko Basin which continues to oklahoma (in Kansas this is still termed the Hugoton Embayment). The depth of sedimentary rocks here reaches 15,000 ft. The Cambridge Arch and the Nemaha anticline are marked and are clearly evident.

V. RESOURCE DATA

Being determined.

VI. GEOTHERMAL ACTIVITY

1. Geothermal workshop at Kansas Geologic Survey, 17 Dec 1976 (1).

2. DOE/DGE Supported Resource Assessment Program (C-6).

VII. LEGAL ACTIVITIES

None at present. 


\section{CONTACTS}

1. Kansas Geological Survey, 1900 Ave. A, Campus West, Univ. of Kansas, Lawrence, KA 66044, Dr. Wm. W. Hambleton, Director; Mr. Owen Spitz, Oil and Gas Geologist; Mr. Donald Steeples, Geophysicist, (913) 864-3965.

\section{REFERENCES AND LIST OF SIGNIFICANT REPORTS}

(1) "Visit to Kansas Geological Survey, Lawrence, Kansas," APL/JHU CPE-77-016, 26 Jan 1977.

(2) "Technical Information Interchange Meeting Minutes," APL/JHU QM-79-261, Dec 1979.

\section{COMMON REFERENCES}

$$
(C-4),(C-6), \text { and }(C-7) \text {. }
$$




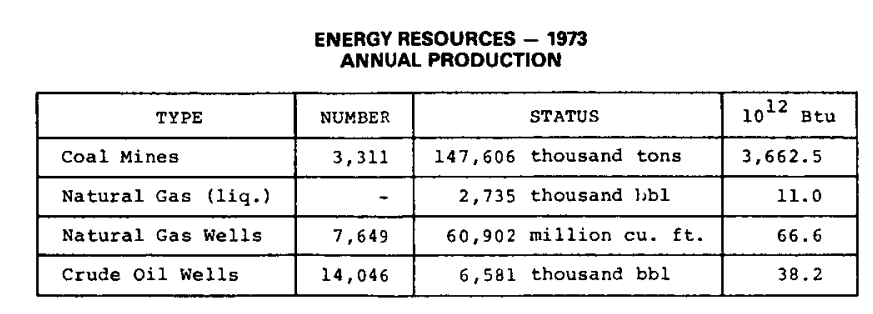

ENERGY USE - 1975 110 B BTU

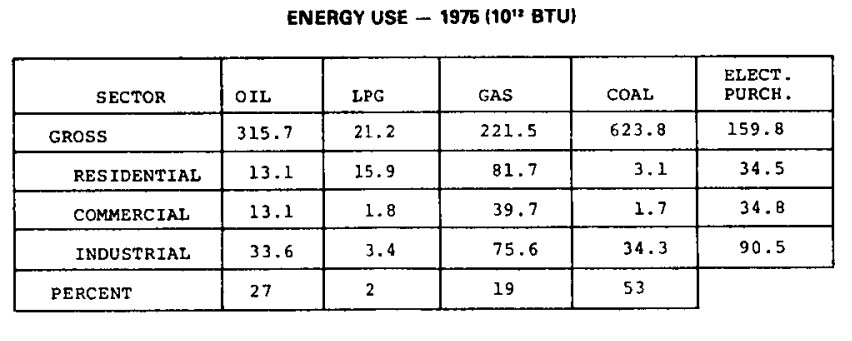

GEOTHERMAL ACTIVITIES

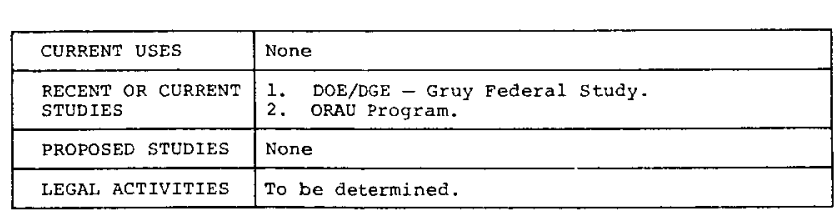

KENTUCKY

SUMMARY SHEET

TOTAL ROPULATTON: 3, 218, 706 TOTAL AREA: 39,650 SQ. MI.

GEOTHERMAL OVERVIEW

A thick sedimentary sequence underlies much of the state.
Potential exists for normal geothermal gradients and hydro-

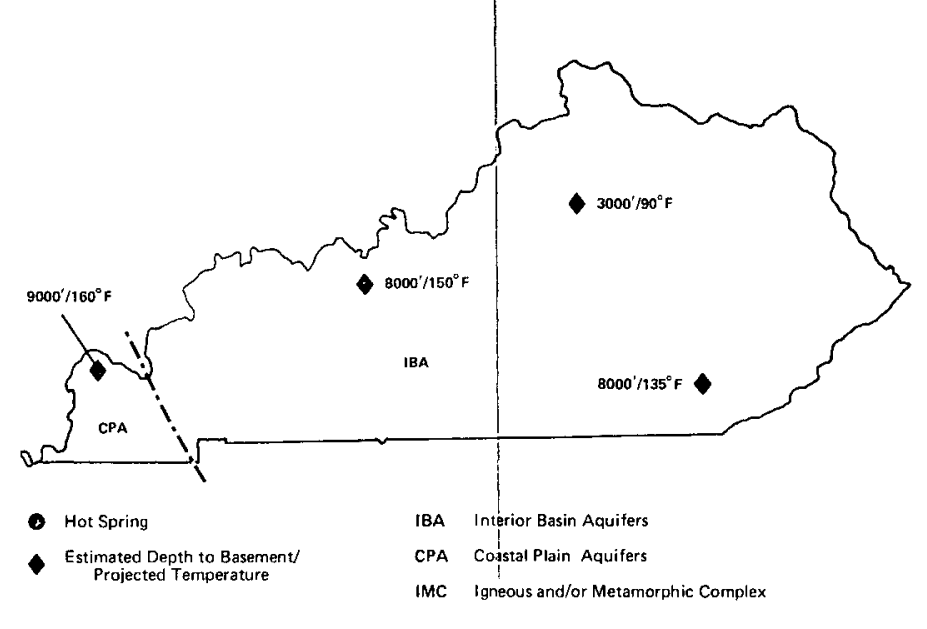

PRIMARY CONTACTS

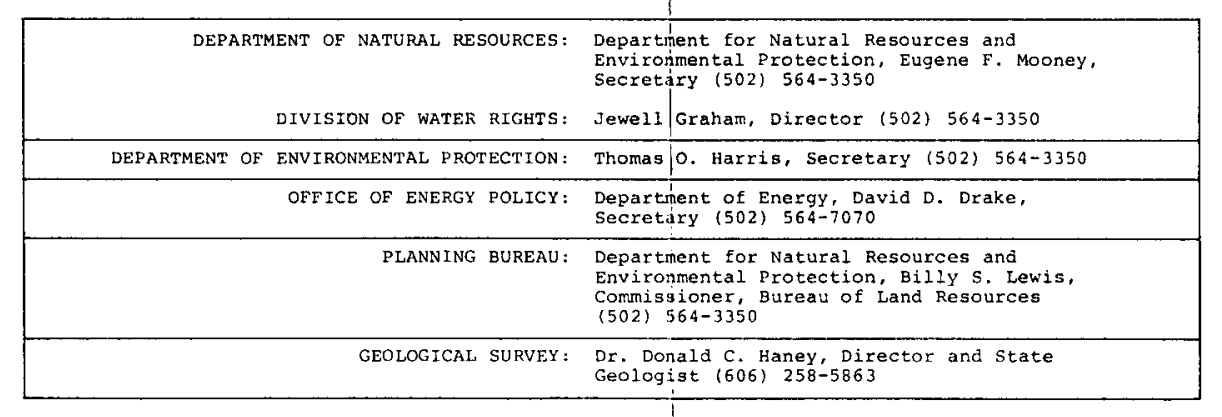

LEGILATIVE CONTACTS

\begin{tabular}{|c|c|}
\hline 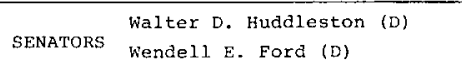 & GOUERNOR John Y. Brown, Jr. \\
\hline $\begin{array}{l}\text { CONGRESSMEN (DIST.) } \\
1-\text { - Carrol1 Hubbard, Jr. (D) }\end{array}$ & \\
\hline $\begin{array}{l}2 \text { - Williaan H. Natcher (D) } \\
3 \text { - Romano I. Mazzoii (D) }\end{array}$ & \\
\hline $\begin{array}{l}4-\text { Gene Snyder }(\mathbb{R}) \\
5 \text { - Harouda Rogers (R) }\end{array}$ & \\
\hline $\begin{array}{l}6-\text { Larry Hogkins (R) } \\
7-\operatorname{car1} 1 \text { D. Pexkins (D) }\end{array}$ & \\
\hline
\end{tabular}



III. STATE FUEL PRODUCTION (1977) (Kentucky Dep't. of Energy)

$$
\text { Type Number Units }
$$

Coal mines

Natural gas (liq.)

Natural gas wells

$$
\begin{array}{rr}
3,311 & 147,646 \text { thousand tons } \\
- & 2,735 \text { thousand bbl } \\
7,649 & 60,902 \text { million cu. } f t \\
14,046 & 6,581 \text { thousand bbl }
\end{array}
$$

Trillion

Btu

$3,662.5$

11.0

66.6

38.2

IV. $\quad$ GEOLOGY

To be supplied.

V. RESOURCE DATA

To be supplied.

VI. GEOTHERMAL ACTIVITY

ORAU Program

VII. LEGAL ACTIVITIES

To be determined.

VIII. CONTACTS

1. Department for Natural Resources and Environmental Protection, Eugene F. Mooney, Secretary, (502) 564-3350.

2. Department of Energy, David D. Drake, Secretary, (502) 564-7070.

3. Geological Survey, Dr. Donald C. Haney, Director and State Geologist, (606) 258-5863.

REFERENCES AND LIST OF SIGNIFICANT REPORTS

(1) ORAU Progress Reports.

COMMON REFERENCES

$(C-4),(C-7)$, and $(C-16)$. 


\section{ENERGY RESOURCES - 1977
ANNUAL PRODUCTION}

\begin{tabular}{|c|c|c|c|}
\hline TYPE & NUMBER & straus & $10^{12}$ вtu \\
\hline Coal Mines & 0 & 0 thousand tons & 0 \\
\hline Natural Gas (1iq.) & & 150,607 thousand bb1 & 607.3 \\
\hline Natural Gas we11s & 10,551 & $8,242,423$ million cu. fft. & $9,009.0$ \\
\hline Crude 0 i1 we $11 \mathrm{~s}$ & 27,869 & 831, 524 thousand bb1 & $4,822.8$ \\
\hline
\end{tabular}

EOTHERMAL DATA SUMMARY SHEET

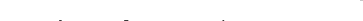

TOTAL POPULATTON: 3,640,490 TOTAL AREA: 44,930 SQ. MI. DOPULATION DENSTTY: 81 PERSONS/SQ. MI

GEOTHERMAL OVERVIEW Louisiana lies within the Mississippi Embayment of the
Gulf Coastal Plain and is underlain by a southward thickening wedge of Paleazoic, Mesozoic, and Tertiary sediThe Jurassic, Smackover, and Norphlet formations and younger fertary sediments ovente he salin these

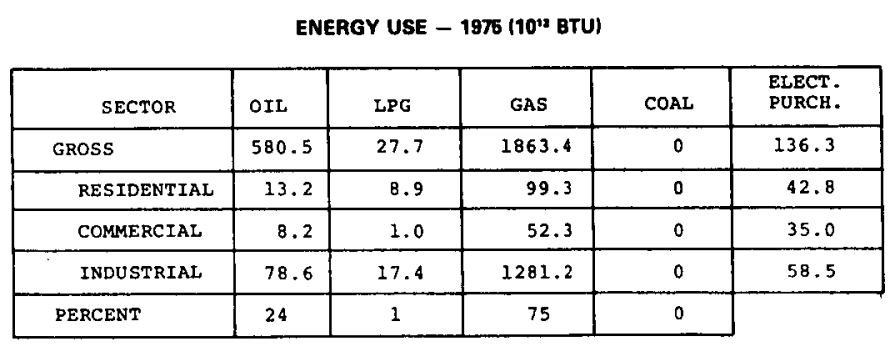

GEOTHERMAL ACTIVITIES

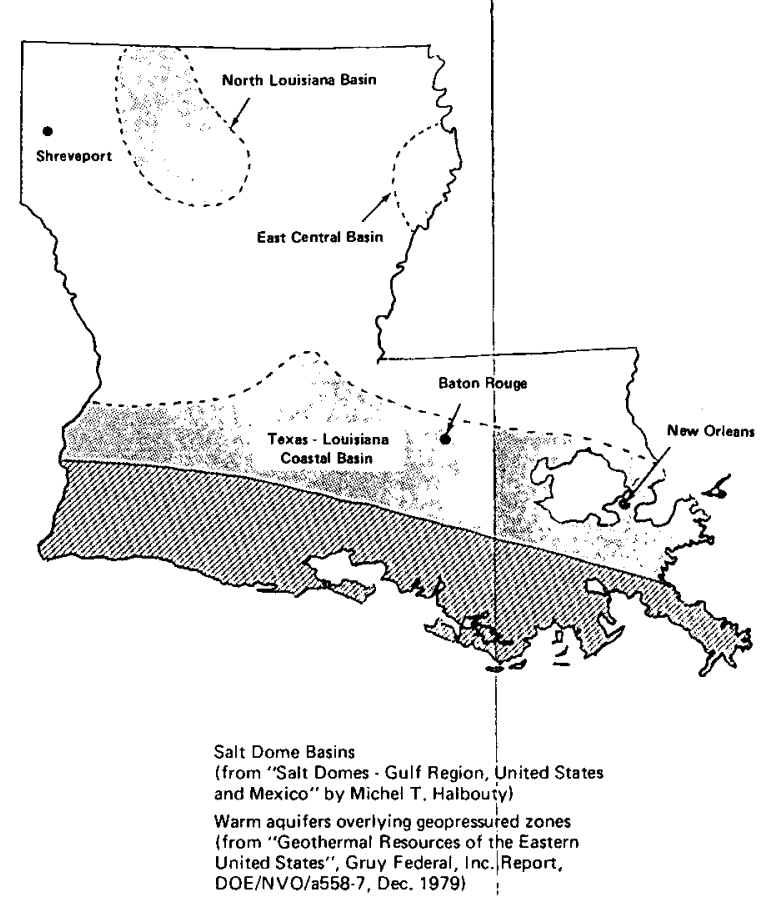

PRIMAAY CONTACTS

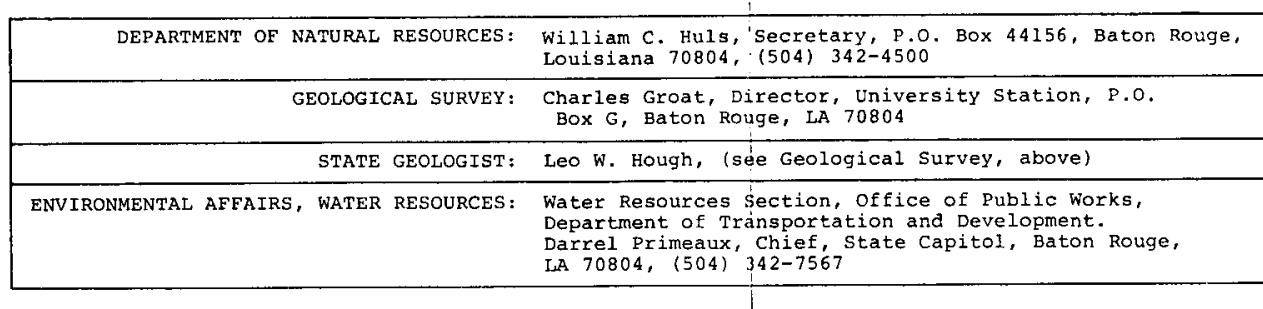

\begin{tabular}{|c|c|}
\hline $\begin{array}{l}\text { SENATORS } \begin{array}{l}\text { Russe11 B. Long (D) } \\
\text { J. Bennett Johnston, Jr. (D) }\end{array}\end{array}$ & GoverNor Edwin w. Eawards (D) \\
\hline $\begin{array}{l}\text { CONGRESSMEN (DIST.) } \\
1-\text { Robert L. Livingston (R) }\end{array}$ & \\
\hline $\begin{array}{l}2 \text { - Lindy (Mrs. Hale) Boggs (D } \\
3 \text { - Daviá C. Treen (R) }\end{array}$ & \\
\hline $\begin{array}{l}4 \text { - Buddy Roemer } \\
5 \text { - Jerry Huckaby (D) }\end{array}$ & \\
\hline $\begin{array}{l}6 \text { - w. Henson Moore (R) } \\
7 \text { - John B. Breaux (D) }\end{array}$ & \\
\hline 8 - Gi11is w. Long (D) & \\
\hline
\end{tabular}


State Geothermal Fact sheet

\section{LOUISIANA}

I. DEMOGRAPHIC INFORMATION (1970) (C-4)

TOTAL STATE

Population: $3,640,490$ Area: 44,930 sq. mi. Density: 81 per sq. mi.

GEOTHERMAL RESOURCE AREA

Population:

Area :

sq. mi. Density: per sq. mi.

II. ENERGY CONSUMPTION* (1975) (C-7)

\begin{tabular}{|c|c|c|c|c|c|}
\hline & $\begin{array}{l}\text { OII } \\
\text { (million } \\
\text { bbl) }\end{array}$ & $\begin{array}{l}\text { LPG } \\
\text { (million } \\
\text { gal.) }\end{array}$ & $\begin{array}{l}\text { GAS } \\
\text { (trillion } \\
\text { cu.ft.) }\end{array}$ & $\begin{array}{l}\text { COAL } \\
\text { (million } \\
\text { tons) }\end{array}$ & $\begin{array}{c}\text { ELECTRICITY } \\
\text { PURCHASED } \\
\text { (billion kWh) }\end{array}$ \\
\hline $\begin{array}{l}\text { GROSS } \\
\text { Residential } \\
\text { Commerical } \\
\text { Industrial }\end{array}$ & $\begin{array}{l}102 \\
0.1 \\
1.4 \\
13\end{array}$ & $\begin{array}{r}290 \\
93 \\
10 \\
182\end{array}$ & $\begin{array}{r}1806 \\
96 \\
51 \\
1242\end{array}$ & $\begin{array}{l}0 \\
0 \\
0 \\
0\end{array}$ & $\begin{array}{l}40 \\
13 \\
10 \\
17\end{array}$ \\
\hline \multicolumn{6}{|c|}{ Trillion Btu } \\
\hline $\begin{array}{l}\text { GROSS } \\
\text { Residential } \\
\text { Commercial } \\
\text { Industrial }\end{array}$ & $\begin{array}{r}580.5 \\
13.2 \\
8.2 \\
78.6\end{array}$ & $\begin{array}{r}27.7 \\
8.9 \\
1.0 \\
17.4\end{array}$ & $\begin{array}{r}1863.4 \\
99.3 \\
52.3 \\
1281.2\end{array}$ & $\begin{array}{l}0 \\
0 \\
0 \\
0\end{array}$ & $\begin{array}{r}136.3 \\
42.8 \\
35.0 \\
58.5\end{array}$ \\
\hline Percentages & 24 & 1 & 75 & 0 & \\
\hline
\end{tabular}

*Excluding nuclear and hydro electricity, coking coal and petroleum coke, and other petroleum products not used as fuels. 
III. STATE FUEL PRODUCTION (1973) $(C-6)$

Type Number Units $\quad$ Btu

Coal mines

Natural gas (liq.)

Natural gas welis

Crude oil wells

$\begin{array}{rrrr}0 & 0 \text { thousand tons } & 0 \\ - & 150,607 \text { thousand bbl } & 607.3 \\ 10,551 & 8,242,423 \text { milition cu. ft. } & 9,009.0 \\ 27,869 & 831,524 \text { thousand bbl } & 4,822.8\end{array}$

IV. GEOLOGY

Louisiana lies within the Mississippi Embayment of the Gulf Coastal plain and is underlain by a southward thickening wedge of Paleozoic, Mesozoic, and Tertiary sediments overlying the Precambrian basement. The state lies on the northern edge of the main Gulf geosyncline and contains many gravity faults. Thick sequences of Jurassic salt deposits (Louann) overlie the older rocks and serve as the source rocks for salt diapirs.

Three salt dome basins occur beneath the state, separated by uplifts. Overlying the salt in these basins, the Jurassic, Smackover, and Norphlet formations, and younger Tertiary sediments commonly contain geopressured reservoirs of oil, gas, and brine.

The shallower, less cemented formations contain near normal gradient hydrothermal resources throughout the state. These widespread lower temperature resources, together with the more local but higher temperature geopressured reservoirs, can provide a substantial energy source for the future.

V. RESOURCE DATA

To be determined.

VI. GEOTHERMAL ACTIVITY

To be determined.

VII. LEGAL ACTIVITIES

To be determined.

VIII. CONTACTS

1. Department of Natural Resources, P.O. Box 44156, Baton Rouge, LA 70804,. William C. Huls, Secretary, (504) 342-4500. 
2. Geological Survey, University Station, P.O. Box G, Baton Rouge, LA 70804, Charles Groat, Director.

3. State Geologist, University Station, P.O. Box G, Baton Rouge, LA 70804, Leo W. Hough.

4. Environmental Affirs, Water Resources Section, Office of Public Works, Department of Transportation and Development, State Capitol, Baton Rouge, LA 70804, Darrel Primeaux, Chief, (504) 342-7567.

REFERENCES AND IIST OF SIGNIFICANT REPORTS

Common references only, see below.

COMMON REFERENCES

$(C-4),(C-6)$, and $(C-7)$. 
ENEREY RESOURCES - 1975
ANNUAL PRODUCTION

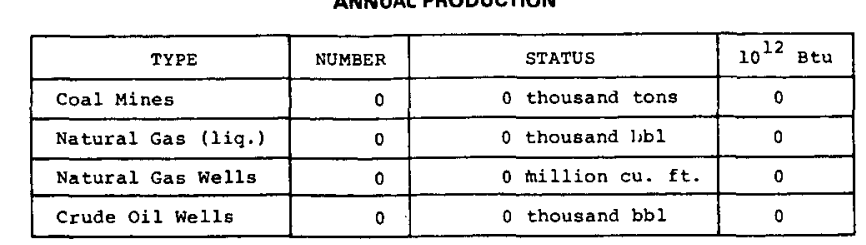

NERGGY USE - 1955 (10' BTU)

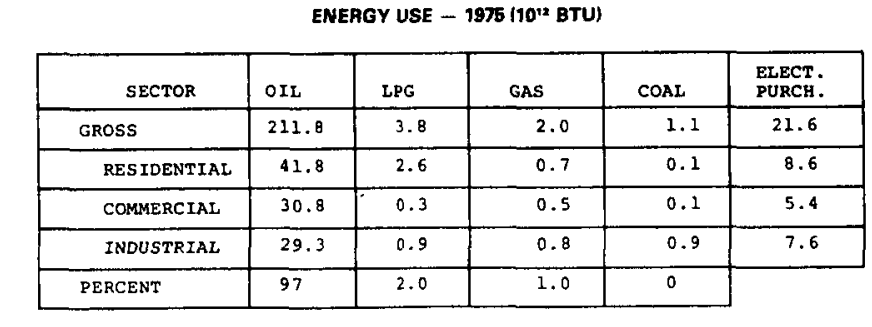

MAINE
GEOTHERMAL DATA SUMMARY SHEET

TOTAL POPULATION: 993,663 TOTAL AREA: 30,920 SQ́.

GEOTHERMAL OVERVIEW

Minor sedimentary cover exists on crystalline basemen
throughout the state. However, posttectonic alkaline plutons with high radioactive element content) occur
the south, and a high heat flow region crosses the stat

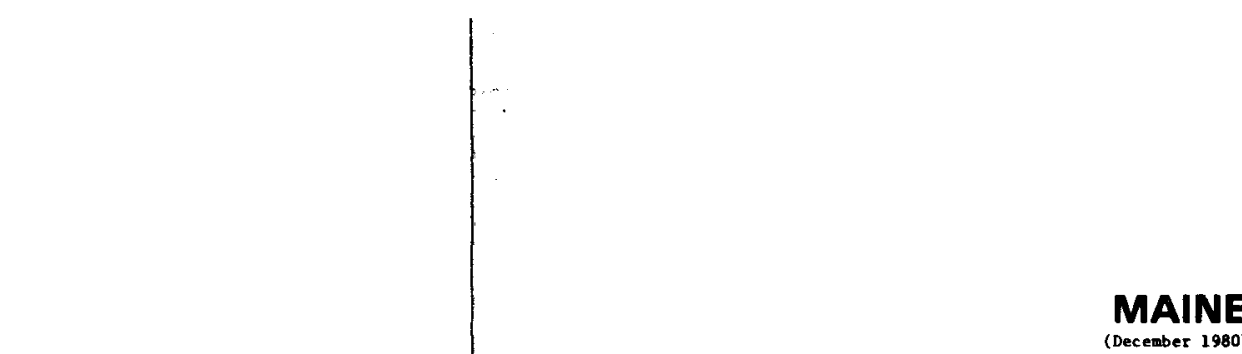

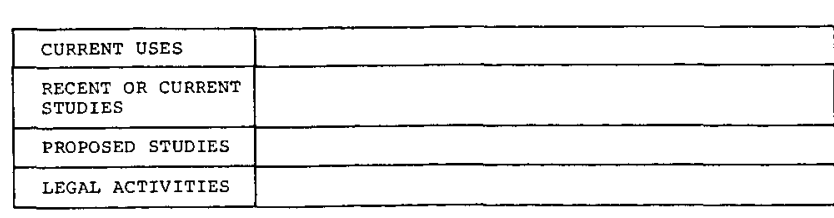
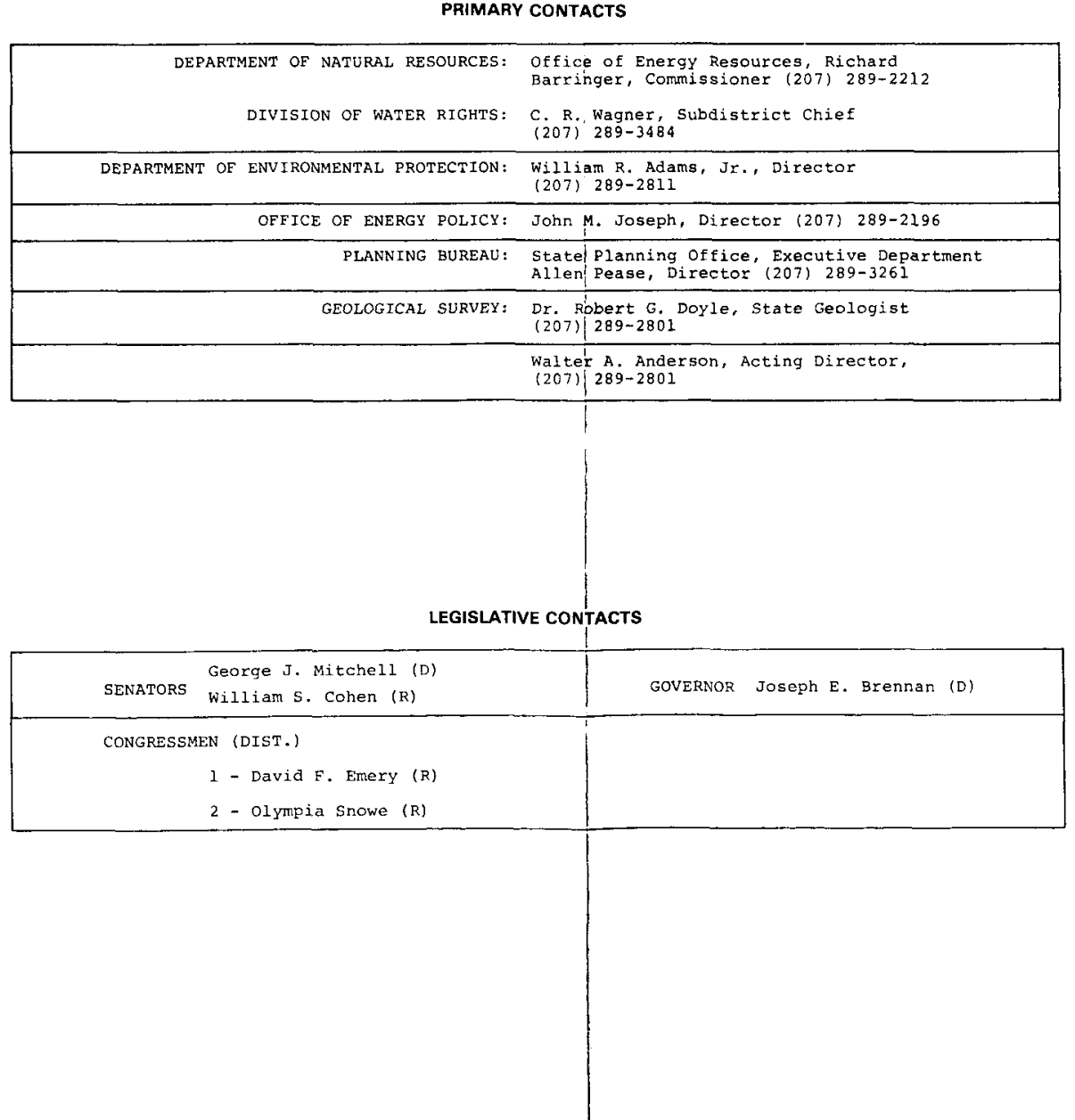

III. STATE FUEL PRODUCTION (1973) $(\mathrm{C}-6)$

Type Number

Coal mines

Natural gas (liq.)

Natural gas wells

Crude oil wells
Units

Trillion

Btu

0 thousand tons 0

0 thousand bbl 0

0 million cu. ft. 0

0 thousand $\mathrm{bbl}$

\section{GEOLOGY}

To be supplied.

V. RESOURCE DATA

To be supplied.

VI. GEOTHERMAI ACTIVITY

To be determined.

VII. LEGAL ACTIVITIES

To be determined.

VIII. CONTACTS

1. Office of Energy Resources, Richard Barringer, Commissioner, (207) 289-2212.

2. Division of Water Rights, C. R. Wagner, Subdistrict Chief, (207) 289-3484.

3. Department of Environmental Protection, William $R$. Adams, Jr., Director, (207) 289-2811.

4. Office of Energy Policy, John M. Joseph, Director, (207) 289-2196.

5. State Planning office, Executive Department, Allen Pease, Director, (207) 289-3261.

6. Geological Survey, Dr. Robert G. Boyle, State Geologist, (207) 28:9-2801.

REFERENCES AND LIST OF SIGNIFICANT REPORTS

Common references only, see below. 
THE JOHNS HOPKINS UNIVERSITY

APPLIED PHYSICS LABORATORY

LAUREL, MAPYLAND

\section{COMMON REFERENCES}

$(C-1),(C-4),(C-6),(C-7)$, and $(C-10)$.

$\mathrm{ME}-3$ 
GEOTHERMAL RESOURCE DATA

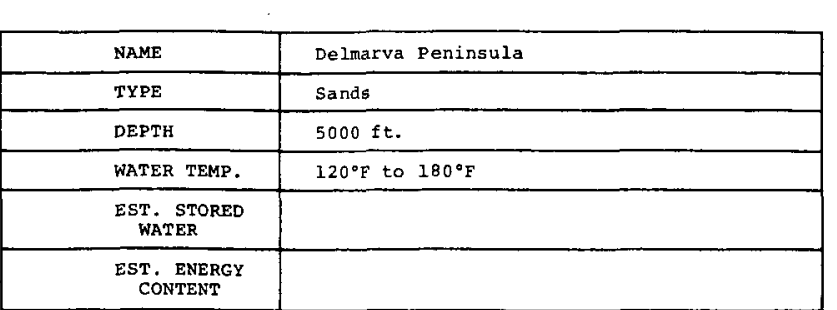

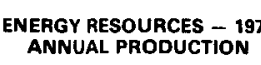

\begin{tabular}{|c|c|c|c|}
\hline TYPE & SUMBER & starus & $10^{12} \mathrm{Btu}$ \\
\hline oal mine & 56 & $1,7,78$ thousand tons & 45.5 \\
\hline Natural Gas (1iq.) & & 0 thousand bb1 & 0 \\
\hline Natural Gas we11s & 15 & $298 \mathrm{mi} 111$ ion cu. $\mathrm{ft}$ & 0.3 \\
\hline Crude 011 we $11 \mathrm{~g}$ & 0 & 0 thousand bb1 & 0 \\
\hline
\end{tabular}

NERQY USE - 1975 (10" BTU

\begin{tabular}{|c|c|c|c|c|c|}
\hline SECTOR & OIL & L28 & GAS & COAL & $\begin{array}{l}\text { ELECEr. } \\
\text { purch }\end{array}$ \\
\hline GRoss & 610.8 & 9.2 & 175.2 & 213.2 & 113.7 \\
\hline RESIDENTIIAL & 59.1 & 5.3 & 85.0 & 0.6 & 35.8 \\
\hline COMMERCAAI & 63.1 & 0.6 & 38.8 & 0.3 & 37.1 \\
\hline FNDUSTRIAAL & 34.3 & 3.2 & 48.7 & 112.5 & 39.5 \\
\hline ERCEN & 61 & 1 & 1) & $\ldots$ & \\
\hline
\end{tabular}

GEOTHERMAL ACTVITIES

\begin{tabular}{|c|c|}
\hline CURREYT USES & None \\
\hline 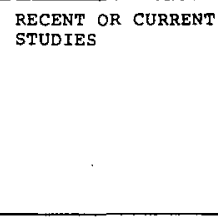 & 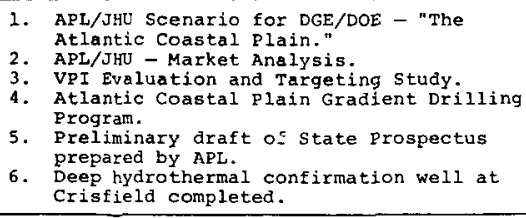 \\
\hline PROPOSED STUDIES & $\begin{array}{l}\text { 1. Technical Assistance by Apt. } \\
\text { 2. } \\
\text { Deap wel1 at cote point. }\end{array}$ \\
\hline LEGAI ACTIVITIES & 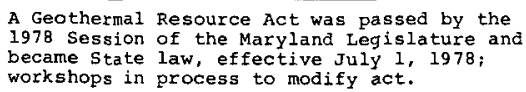 \\
\hline
\end{tabular}

MARYLAND/D.C.
GEOTHERMAL DATA SUMMARY cef. State Geothernal Fact sheet, Maryland/District of columb

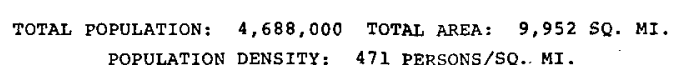

GEOTHERMAL OVERVIEW

The Atlantic Coastal Plain area under the Delmarra Penin-

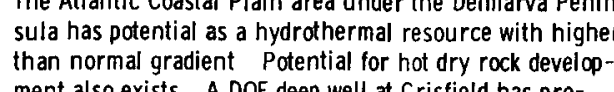

ment also exists. A DOF deep well at Crisfield has pro-
vided preliminary intormation on both types of resources

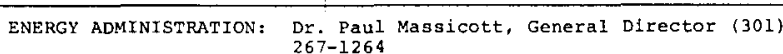
ENERGY OFFICE: Dr, Donald E. Milsten, Director (301) 383-6810 VATER RESOURCES ADMINITSTRATION: Thomas C. Andrews, Director (301) 264-3846

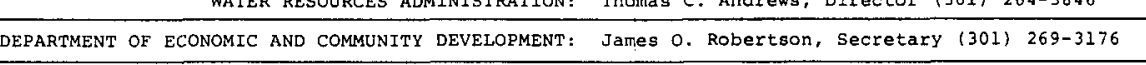

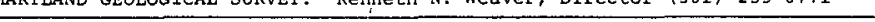
(a)

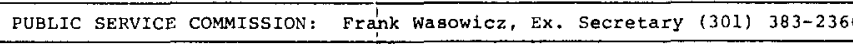

LEGISLATINE CONTACTS

\begin{tabular}{|c|c|}
\hline GOVERNOR & Harry R. Hughes (D) (301);269-3591 \\
\hline SENATORS & 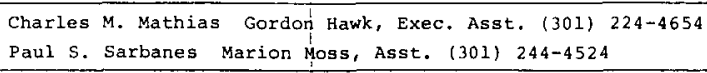 \\
\hline CONGRESSMAN (DIIST.) & 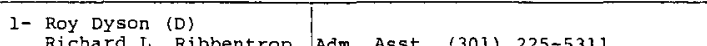 \\
\hline COONIIES OF GEOTHRRMA & $\begin{array}{l}\text { AL INREREST: } \\
\text { Carolina }\end{array}$ \\
\hline & $\begin{array}{l}\text { Dorchester } \\
\text { Queen Anne }\end{array}$ \\
\hline & $\begin{array}{l}\text { Sommerset } \\
\text { ralbot }\end{array}$ \\
\hline & 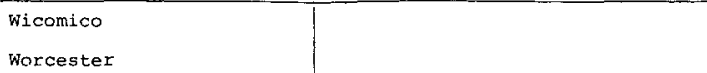 \\
\hline
\end{tabular}


State Geothermal Fact sheet

MARYLAND \& DISTRICT OF COLUMBIA

I. DEMOGRAPHIC INFORMATION (1970) (C-4)

TOTAL STATE

Population: 4,688,000 Area: $9,952 \mathrm{sq} \cdot \mathrm{mi}$. Density: 471 per sq. mi.

GEOTHERMAL RESOURCE AREA

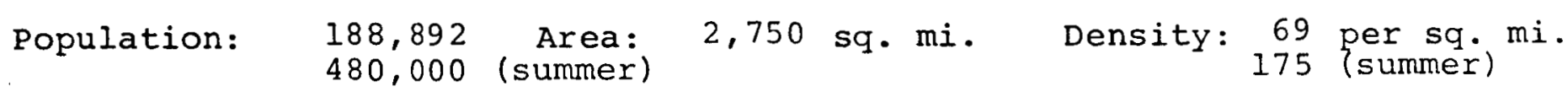

II. ENERGY CONSUMPTION* (1975) (C-7)

\begin{tabular}{|c|c|c|c|c|c|}
\hline & $\begin{array}{l}\text { OIL } \\
\text { (million } \\
\text { bbl) }\end{array}$ & $\begin{array}{l}\text { LPG } \\
\text { (million } \\
\text { gal.) }\end{array}$ & $\begin{array}{c}\text { GAS } \\
\text { (trillion } \\
\text { cu.ft.) }\end{array}$ & $\begin{array}{l}\text { COAL } \\
\text { (million } \\
\text { tons) }\end{array}$ & $\begin{array}{l}\text { ELECTRIC } \\
\text { PURCHAS } \\
\text { (billion }\end{array}$ \\
\hline $\begin{array}{l}\text { GROSS } \\
\text { Residential } \\
\text { Commerical } \\
\text { Industrial }\end{array}$ & $\begin{array}{r}107 \\
10 \\
11 \\
6\end{array}$ & $\begin{array}{r}96 \\
55 \\
6 \\
34\end{array}$ & $\begin{array}{r}170 \\
32 \\
38 \\
47\end{array}$ & $\begin{array}{l}8 . \\
0.01 \\
0.00 \\
0.25\end{array}$ & $\begin{array}{l}33 \\
11 \\
10 \\
12\end{array}$ \\
\hline \multicolumn{6}{|c|}{ Trillion Btu } \\
\hline $\begin{array}{l}\text { GROSS } \\
\text { Residential } \\
\text { Commercial } \\
\text { Industrial }\end{array}$ & $\begin{array}{r}610.8 \\
59.1 \\
63.1 \\
34.3\end{array}$ & $\begin{array}{l}9.2 \\
5.3 \\
0.6 \\
3.2\end{array}$ & $\begin{array}{r}175.2 \\
85.0 \\
38.8 \\
48.7\end{array}$ & $\begin{array}{r}213.2 \\
0.6 \\
0.3 \\
112.5\end{array}$ & $\begin{array}{r}113.7 \\
35.8 \\
37.1 \\
39.5\end{array}$ \\
\hline
\end{tabular}

Percentages

61

1

17

21

*Excluding nuclear and hydro electricity, coking coal and petroleum coke, and other petroleum products not used as fuels. 
III. STATE FUEL PRODUCTION (1973) $(\mathrm{C}-6)$

Type Number Units $\begin{gathered}\text { Trillion } \\ \text { Btu }\end{gathered}$

Coal mines

Natural gas (liq.)

Natural gas wells

crude oil wells

$\begin{array}{rr}56 & 1,788 \text { thousand tons } \\ - & 0 \text { thousand bbl } \\ 15 & 298 \text { milion cu. ft. } \\ 0 & 0 \text { thousand bbl }\end{array}$

45.5
0
0.3
0

IV.

GEOLOGY

The area of Maryland that is of current geothermal interest is the Atlantic Coastal Region, the so-called Eastern shore of Maryland. The geology of this region is typical of the Delmarva Peninsula: the coastal plain consists of a thickening wedge of Mesozoic and Cenozoic sedimentary rocks. The basement is deeper than $7500 \mathrm{ft}$. at Ocean City and is from $4000 \mathrm{ft}$. or deeper in the contiguous counties of the southern Eastern shore of the Chesapeake Bay. It is assumed (and verified by some recent data) that the top of the basement slopes down to the east into the Atlantic ocean (3). Deep sandstone aquifers are known to under lie this region. The DOE/DGE deep well at Crisfield, which was spudded on 13 May 1979, and drilled into basement, gave the basement depth as $4460 \mathrm{ft}$. and provided stratigraphic data to $5550 \mathrm{ft}$ (3). This well, which was also pump tested, provided information on deep aquifer water yield.

\section{RESOURCE DATA}

In the late 1940's three holes deeper than $5000 \mathrm{ft}$. were arilled on the Eastern Shore by oil companies. One of these, "Maryland Esso No. 1," in Ocean City was drilied to $7710 \mathrm{ft}$. and had a bottom hole temperature measured at $216^{\circ} \mathrm{F}$. The DOE $1000 \mathrm{ft}$. well drilling program, conducted by VPI\&SU, drilled 13 holes in Maryland. The gradient drilling program indicated a massive pluton under the chesapeake Bay and a smaller one under Wallops Island; higher-than-normal gradients are found on a line from smith's point on the Western Shore of the Chesapeake Bay at the mouth of the Potomac River to Wallops Island on the Atlantic Coast. Other gradients appear to be normal.

The deep well drilled by DOE at Crisfield was pump tested for 3 deep aquifers. The most productive one was 86 ft. thick located about $3950 \mathrm{Et}$. down, had a temperature of about $133^{\circ} \mathrm{F}$, a computed permeability of 110 millidarcies, and a storage coefficient of $4 \times 10^{-3}$. This well was extended into the basement as part of the Los Alamos (LASL) hot dry rock program. 
VI.

\section{GEOTHERMAL ACTIVITY}

The VPI\&SU $1000 \mathrm{ft}$. gradient well program has been completed and the deep well into basement at Crisfield has been tested and abandoned. Under DOE/PRDA, a feasibility study has been completed for a food processing plant in Salisbury. APL has completed the market study of potential geothermal application for the Eastern shore. Four technical assistance studies completed by APL include two schools, a mariculture industry on the Eastern shore, and the LNG facility at Cove Point on the Western Shore.

Beginning in mid or late 1980, APL will conduct four or five technical assistance studies for Ocean City, Salisbury, and snow Hill. DOE plans to have VPI\&SU drill a production test well at Cove Point. Drilling sites are shown on page MD-6.

VII. LEGAL ACTIVITIES

A Geothermal Resource Act was passed by the Maryland Legislature and became state Law 1 July 1978. NCSL is conducting workshops with the State Joint Legislative Subcommittee to modify the existing law.

VIII. CONTACTS

1. Energy Administration, Department of Natural Resources, James State Office Bldg., Annapolis, MD 21401, Dr. Paul Massicott, General Director, (301) 267-1264.

2. Energy Office (part of Energy Administration), 301 West Preston Street, Suite 1302, Baltimore, MD 21201, Dr. Donald E. Milsten, Director, (301) 383-6810.

3. Energy Conservation and Alternative Energy Sources (State Energy office), 301 West Preston Street, Suite 1302, Baltimore, MD 21201, Felicity Evans, Chief, (301) 383-6810.

4. Water Resources Administration, Department of Natural Resources, Tawes State Office Building, Annapolis, MD 21401, Thomas C. Andrews, Director, (301) 269-3846.

5. Department of Economic and Community Development, 2525 Riva Road, Annapolis, MD 21401, James o. Robertson, Secretary, (301) 269-3176.

6. Public Service Commission, 301 west Preston Street, Baltimore, MD 21201, Thomas Hatem, Chairman; Frank Wasowicz, Executive Secretary, (301) 383-2366. 
7. Special Joint Committee on Energy (Legislature)

a. Delegate - Catherine I. Riley, Chairman, 20 office Street, Bel Air, MD 21014.

b. Senator - Peter A. Bozick, Co-Chairman, 5606 Lansing Drive, Camp Springs, MD 20.031.

8. Maryland Geological Survey, Merryman Hall, The Johns Hopkins University," Baltimore, MD 21218, Dr. Kenneth N. Weaver, Director, (301) 235-0771.

9. Environmental Health Administration, 201 W. Preston Street, Baltimore, MD 21201, Max Eisenberg, (301) 383-2740.

10. Department of State Planning, 301 West Preston Street, Baltimore, MD 21229, Constance Lieder, Secretary, (301) 383-2450.

11. State Coupled Reservoir Assessment Program, Merryman Hall, The Johns Hopkins University, Baltimore, MD 21218, Dr. Ken Schwarz, Principal Contact, (301) 235-0771.

REFERENCES AND LIST OF SIGNIFICANT REPORTS

(1) P. M. Brown, J. A. Miller and F. M. Swain, "Structural and Stratigraphic Framework and Spatial Distribution of Permeability of the Atlantic Coast Plain, North Carolina to New York," U.S.G.S. Professional Paper 796, 1972.

(2) R. N. Benson, "Review of the Subsurface Geology and Resources Potential of Southern Delaware," Delaware Geological Survey, Open File Report, 1976.

(3) "Geothermal Energy and the Eastern U.S.: A Framework for a Site Prospectus for Geothermal Energy Development, Delmarva Peninsula," APL/JHU QM-79-145, Jun 1979.

(4) "Evaluation and Targeting of Geothermal Energy Resource in the Southeastern United States," VPI\&SU, Blacksburg, VA, Report Nos. VPI\&SU-5648-5 and VPI\&SU-78ET-27001-7.

(5) "Geothermal Energy and the Eastern U.S., Technical Information Exchange Meeting," APL/JHU QM-79-261:

Chapter VII. - R. Gleason and L. Lambriase, "Mid Atlantic and Southeastern Moderate Temperature Program, Geologic setting and Targeting Process;" 
Chapter VIII - J. C. Maxwell, "The Hot Dry Rock Eastern Program;"

Chapter XII - K. Schwarz, "The Crisfield Well, Somerset County, Maryland;" *

Chapter XIII - J. H. Hartsock, "Analysis of Test Data from DOE Crisfield Airport Well No. 1 Well;"

Chapter XIV - K. Yu, "Crisfield Well Characteristics Determined Using AIl Test Data;" and

Chapter XV - F. C. Paddison, "Geothermal Heating for the Crisfield Maryland High School."

(6) "Completion Report Gruy Federal Inc - Department of Energy Crisfield Airport No. 1 Well, Somerset County, Maryland," Part I: Drilling and Completion, Aug 1979, Part II: Well Test Analysis, Oct 1979, Gruy Federal, Inc. 2500 Tanglewild Drive, Suite 150 Houston, TX 77063.

(7) "Technical Assistance Report No. 4, Geothermal Space Heating - Pittsville Middle/Elementary School, Pittsville, Maryland," JHU/API QM-80-101, Jun 1980.

(8) "Utilization of Geothermal Energy at the Cove Point LNG Receiving Terminal," Columbia LNG Corporation, 20 Montchanin Road, Wilmington, Delaware, 19807.

(9) "Geothermal Resources for the Eastern United States," Gruy Federal, Inc. Report for the Deportment of Energy, $\mathrm{DOE} / \mathrm{ET} / 288373-\mathrm{T} 2$.

(10) "Preliminary Results for the Technical Assistance to Columbia LNG Corporation," APL/JHU QM-80-047.

(11) "The Crisfield, Maryland Well and Geothermal Energy," Letter to Mr. W. L. Rice, DOE/RA, JHU/APL CQO-2554, 12 Nov 1979.

"Geothermal Energy and the Eastern U.S., A Scenario for Geothermal Energy Development, The Atlantic Coastal Plain," APL/JHU QM-77-129, Oct 1977.

COMMON REFERENCES

$(C-1),(C-2),(c-3),(C-4),(c-6)$, and $(C-7)$. 


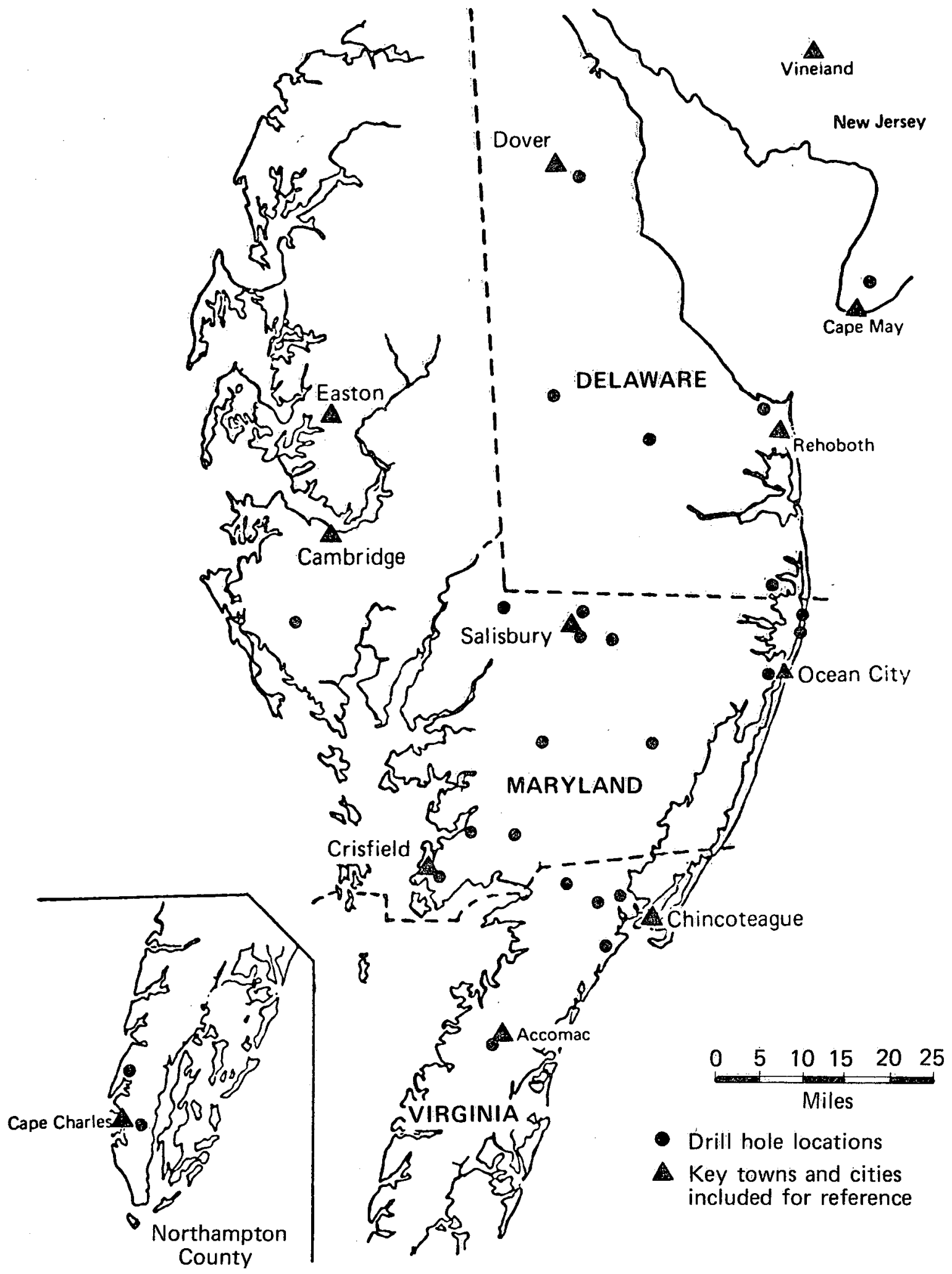

Locations of gradient test holes - Delmarva 
ENERGY RESOUACES - 1973
ANNUAL PROOUCTION

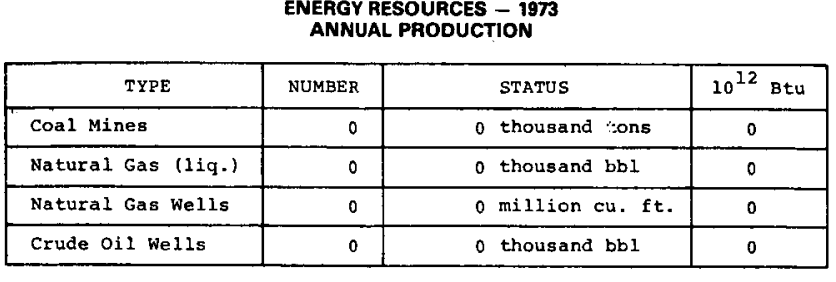

NERGY USE - 1975 110'1 BTU

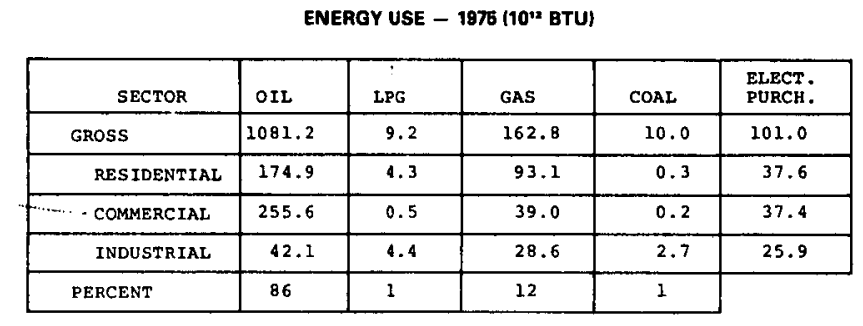

geotuseman Activites

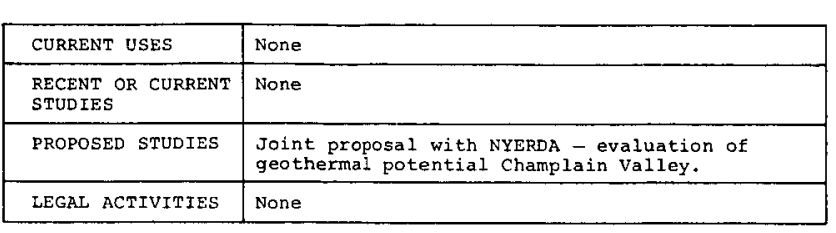

MASSACHUSETTS

GEOTHERMAL DATA SUMMARY SHEET

(cf. State Geothernal Fact Sheet, Massackusetts)

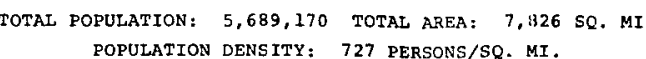

GEOTHERMAL OVERVIEW

in the western part of the state, a deep highly faulted

作

has a potential for hot dry rock or hydrothermal development.

- Hor Spring

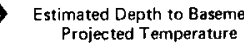

IBA Intrerior Basin Aquites

IMC Igneous and/or
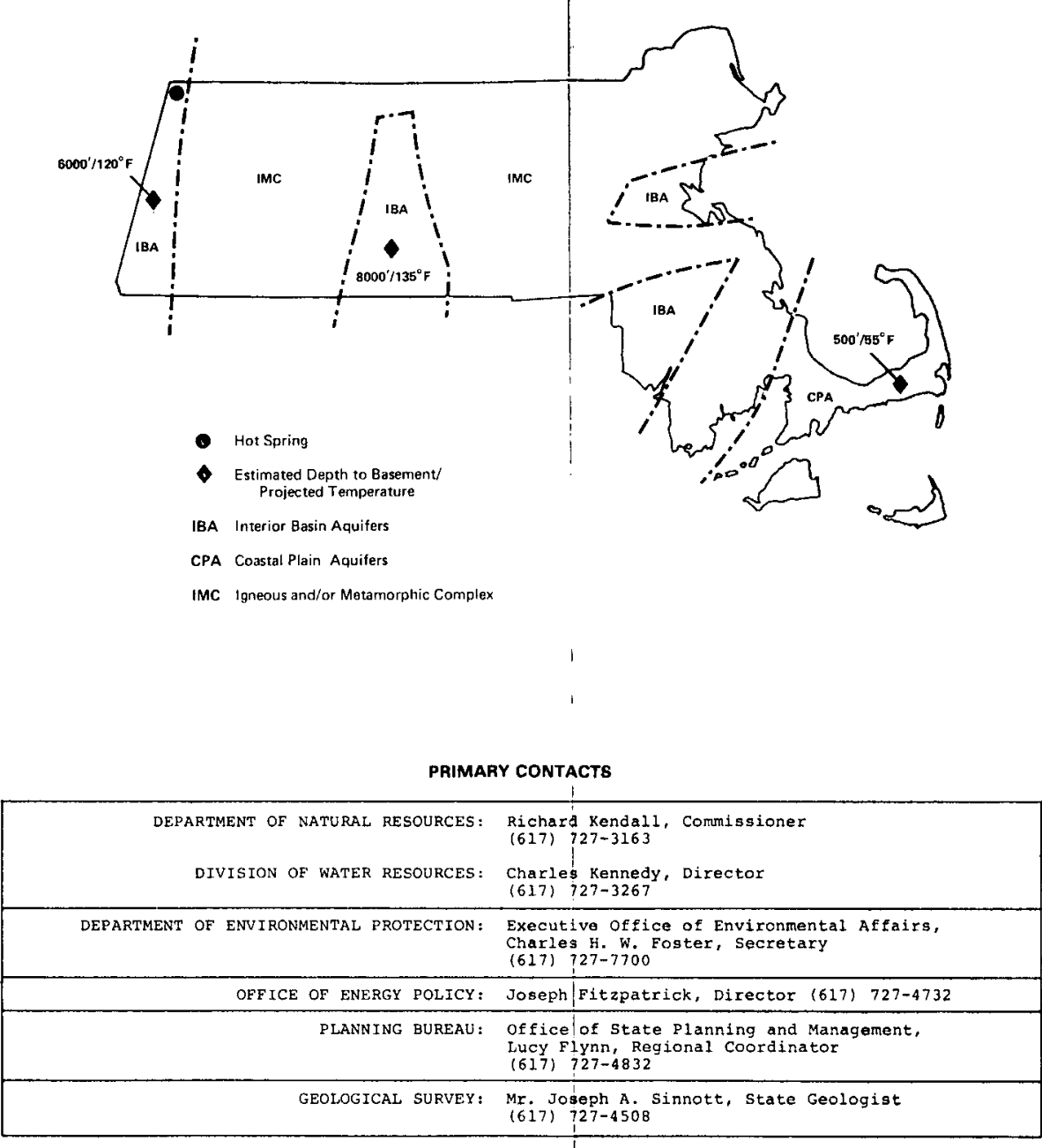

LEGILATIVE CONTACTS

\begin{tabular}{|c|c|}
\hline 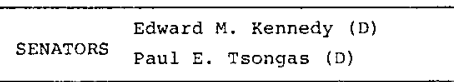 & GOVERNOR EAward J. King (D) \\
\hline $\begin{array}{l}\text { COMGRESSNEN (DIST.) } \\
1 \text { - Silvio O. Conte (R) }\end{array}$ & 7 - Edwarad J. Markey (D) \\
\hline $\begin{array}{l}2-\text { Edward P. Bcland (D) } \\
3-\text { Joseph D. Early (D) }\end{array}$ & $\begin{array}{l}8-\text { Thomas P. O'Nei11, Jr. (D) } \\
9-\text { John J. Moakley (D) }\end{array}$ \\
\hline $\begin{array}{l}4-\text { Barney Frank (D) } \\
5 \text { - Janes shannon }(0) \\
\end{array}$ & $\begin{array}{l}10-\text { Margaret } M \text {. Hecklex }(\mathrm{R}) \\
11-\text { - Brian Donnel1y }(\mathrm{D})\end{array}$ \\
\hline 6 - Nicholas Mavroules (D) & 12 - Gerry E. Studds (D) \\
\hline
\end{tabular}


State Geothermal Fact sheet

MASSACHUSETTS

I. DEMOGRAPHIC INFORMATION (1970) (C-4)

TOTAL STATE

Population: 5,689,170 Area: $7,826 \mathrm{sq} \cdot \mathrm{mi}$. Density: 727 per sq. mi.

GEOTHERMAL RESOURCE AREA

Population:

Area :

sq. mi .

Density :

per sq. mi.

II. ENERGY CONSUMPTION*

(1975) (C-7)

$\begin{array}{lc} & \begin{array}{c}\text { OIL } \\ \text { (million } \\ \text { bbl) }\end{array} \\ \text { GROSS } & 186 \\ \text { Residential } & 30 \\ \text { Commerical } & 42 \\ \text { Industrial } & 7 \\ & \\ & \\ \text { GROSS } & 1081.2 \\ \text { Residential } & 174.9 \\ \text { Commercial } & 255.6 \\ \text { Industrial } & 42.1\end{array}$

LPG

GAS

COAL

(million

gal.)

(trilion

cu.ft.)

(million

tons)

0.41

0.01

0.01

0.10

\section{ELECTRICITY}

PURCHASED

(billion kWh)

45
5
46

90

38

28

30
11
11
8

Trillion Btu

Percentages

$\begin{array}{rr}9.2 & 162.8 \\ 4.3 & 93.1 \\ 0.5 & 39.0 \\ 4.4 & 28.6\end{array}$

$$
\begin{array}{r}
10.0 \\
0.3 \\
0.2
\end{array}
$$

2.7

101.0

37.6

37.4

25.9

86

1

12

1

*Excluding nuclear and hydro electricity, coking coal and petroleum coke, and other petroleum products not used as fuels. 
III. STATE FUEL PRODUCTION (1973) (C-6)

Type Number
Units

0 thousand tons

0 thousand bbl

0 million cu. ft.

0 thousand $\mathrm{bbl}$
Trilition Btu

Coal mines

Natural gas (liq.)

Natural gas wells

Crude oil wells
0

0

0

IV. GEOLOGY

Massachusetts is largely underlain by low grade to high grade metamorphic rocks and igneous intrusions. These rocks are of Precambrian and Paleozoic age and were deformed or emplaced during the Paleozoic orogenies. The western part of the state coincides with the Champlain Valley, which is underlain by a deep, complexly faulted sequence of sedimentary rocks. Warm springs occur in this area and are fault controlled. The connecticut Valley Triassic Basin extends through the central part of the state and its thickness exceeds $10,000 \mathrm{ft}$. This basin is bounded by deep-seated fault zones. Both of these areas are attractive for harboring geothermal energy because they consist of thick sedimentary sequences that act as insulating blankets and are associated with significant faulting. Little is known about water availability at depth; however, many of the sedimentary units are highly indurated making fracturing and faulting important for the circulation of water.

$\mathrm{V}$.

RESOURCE DATA chusetts.

Few subsurface temperature data are available for Massa-

VI. GEOTHERMAL ACTIVITY

Joint proposal with NYERDA - evaluation of geothermal potential of Champlain Valley.

VII. LEGAL ACTIVITIES

To be determined.

VIII. CONTACTS

1. Department of Natural Resources, Richard Kendal1, Commissioner, (617) 727-3163. 
2. Division of Water Resources, Charles Kennedy, Director, (617) 727-3267.

3. Department of Environmental Protection, Executive Office of Environmental Affairs, Charles H. W. Foster, Secretary, (617) 727-7700.

4. Office of Energy Policy, Joseph Fitzpatrick, Director, (6I7) 727-4832.

5. Office of state Planning and Management, Lucy Flynn, Regional Coordinator, (617) 727-4732.

6. Geological Survey, Mr. Joseph A. Sinnott, State Geologist, (617) 727-4508.

REFERENCES AND LIST OF SIGNIFICANT REPORTS

Common references only, see below.

COMMON REFERENCES

$(C-1),(C-4),(C-6),(C-7)$, and $(C-10)$. 
ENERGY RESOURCES - 1975
ANNUAL PRODUCTION

\begin{tabular}{|c|c|c|c|}
\hline TYPE & NUMBER & $\begin{array}{l}\text { sratus } \\
\end{array}$ & $10^{12} \mathrm{Btu}$ \\
\hline Coal Kines & 0 & 0 thousand tons & $\sigma_{0}$ \\
\hline Natural Gas (1iq.) & & 1,063 thousand bb1 & 4.3 \\
\hline Watural Gas Wel12s & 1,245 & 44,579 mi il1ion cu. $f t$. & 48.7 \\
\hline Crude oil wells & 3,793 & 14,614 thousand bb1 & 84.8 \\
\hline
\end{tabular}

\begin{tabular}{|c|c|c|c|c|c|}
\hline SEctror & OII & LPG & GAS & COAL & $\begin{array}{l}\text { EIIECT: } \\
\text { PURCA: }\end{array}$ \\
\hline GRoss & 975.1 & 28.6 & 915.9 & 776.4 & 213.7 \\
\hline RESTOENTTAL & 108.3 & 22.2 & 345.6 & 5.3 & 71.0 \\
\hline 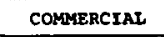 & 74.7 & 2.5 & 187.8 & 2.9 & 50.4 \\
\hline INDUSTRIAL & 48.0 & 3.9 & 323.3 & 120.7 & 92.3 \\
\hline PRRCENT & 36 & & 34 & 29 & \\
\hline
\end{tabular}

GEOTHERMAL ACTVTIIES

\begin{tabular}{|c|c|}
\hline CURREYY USES & Kone \\
\hline $\begin{array}{l}\text { RECENT OR CURRENT } \\
\text { STYUTISS }\end{array}$ & 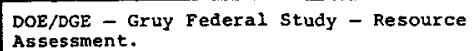 \\
\hline PROPOSED STUDIES & None \\
\hline
\end{tabular}

GEOTHERMAL OVERVIEW

A deep sedimentary basin may hwe potential as a hydro-
GEOTHERMAL DATA SUMMARY SHEE

lcf, state coothermal Fact sneet, Michisen)

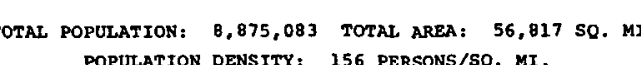

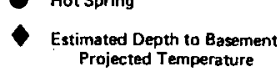

IBA Interior Besin Aaviters

CPA Cossti Plain A Aquiters

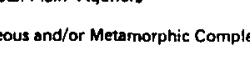

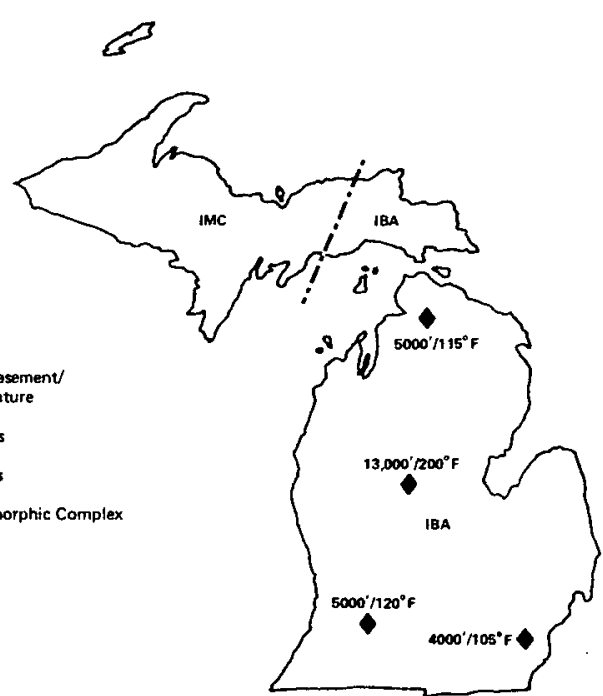

agmagy contacts

\begin{tabular}{|c|c|}
\hline DEPRRTMENT OF ENVI RONMENTAL PROTECTTON: & 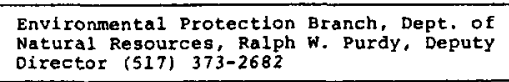 \\
\hline OFFICE OF ENERCY POLICY: & 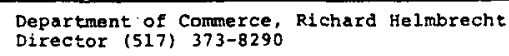 \\
\hline PLANNING BUREAU: & 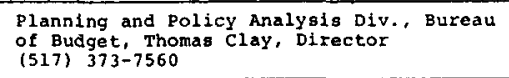 \\
\hline GEO & 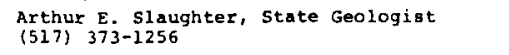 \\
\hline
\end{tabular}

LEGILLATNE CONTACTS

Donald W. Riegle, Jr. (D) GOVERNor william G. Milliken (R)

\begin{tabular}{|c|c|}
\hline \multicolumn{2}{|l|}{ CONGRESSHEN (DIST.) } \\
\hline $\begin{array}{l}1-\text { John conyers, Jr. (D) } \\
2-\text { Carl D. pursel1 (R) }\end{array}$ & $\begin{array}{l}11 \text { - Robert } \mathrm{H} \text {. Davis }(R) \\
12 \text { - Davidid Bonior }(D)\end{array}$ \\
\hline 3- Howard Wolpe (D) & $\begin{array}{l}13 \text { - George Crokett, } J \text { r. (D) } \\
14 \text { - Dennis } M \text {. Hertel (D) }\end{array}$ \\
\hline $\begin{array}{l}5 \text { - Harold } S \text {. Sauyer (R) } \\
6 \text { - Jim Dunn (R) }\end{array}$ & $\begin{array}{l}15 \text { - Wil11 iam D. Ford (D) } \\
16-\text { John D. Dingel1 (D) }\end{array}$ \\
\hline $\begin{array}{l}7 \text { - Dale E. Xildae (D) } \\
g \text { - Bob Traxier (D) }\end{array}$ & $\begin{array}{l}17 \text { - will1 iam M. Brodhead (D) } \\
18 \text { - Janes J. Blanchard (D) }\end{array}$ \\
\hline $\begin{array}{l}9-\text { Guy A. Vandersagat (R) } \\
10 \text { - Donald Joseph AAbosta (D) }\end{array}$ & $19-$ william S. Broonffield (R) \\
\hline
\end{tabular}


State Geothermal Fact sheet

\section{MICHIGAN}

I. DEMOGRAPHIC INFORMATION (1970) (C-4)

TOTAL STATE

Population: 8,875,083 Area: $56,817 \mathrm{sq} \cdot \mathrm{mi}$. Density: $156 \mathrm{per} \mathrm{sq} \cdot \mathrm{mi}$.

GEOTHERMAL RESOURCE AREA

Population: Area: sq. mi. Density: per sq. mi.

II. ENERGY CONSUMPTION* (1975) (C-7)

$\begin{array}{ccccc}\begin{array}{c}\text { OIL } \\ \text { (milion }\end{array} & \begin{array}{c}\text { LPG } \\ \text { (million }\end{array} & \begin{array}{c}\text { GAS } \\ \text { (trillion } \\ \text { gal.) }\end{array} & \begin{array}{c}\text { COAL } \\ \text { (million } \\ \text { tons) }\end{array} & \begin{array}{c}\text { ELECTRICITY } \\ \text { PURCHASED } \\ \text { (billion kWh) }\end{array} \\ 177 & 300 & 887 & 31 & 63 \\ 19 & 232 & 335 & 0.2 & 21 \\ 13 & 26 & 182 & 0.1 & 15 \\ 8 & 40 & 313 & 4 & 27\end{array}$

Trillion Btu

$\begin{array}{crrrrr}\text { GROSS } & 975.1 & 28.6 & 915.9 & 776.4 & 213.7 \\ \text { Residential } & 108.3 & 22.2 & 345.6 & 5.3 & 71.0 \\ \text { Commercial } & 74.7 & 2.5 & 187.8 & 2.9 & 50.4 \\ \text { Industrial } & 48.0 & 3.9 & 323.3 & 110.7 & 92.3\end{array}$

$\begin{array}{lllll}\text { Percentages } & 36 & 1 & 34 & 29\end{array}$

*Excluding nuclear and hydro electricity, coking coal and petroleum coke, and other petroleum products not used as fuels. 
III. STATE FUEL PRODUCTION (1973) (C-6)

Type Number Units $\quad$ Trillion

Coal mines

Natural gas (liq.)

Natural gas wells

Crude oil wells

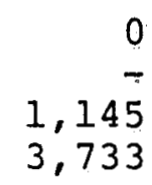

0 thousand tons

1,063 thousand bbl

44,579 milition cu. ft.

14,614 thousand bbl
0

4.3

48.7

84.8

IV. $\quad$ GEOLOGY

The geology of Michigan is dominated by a large central. basin, which in large part underlies the Lower Peninsula. The depth of this sedimentary basin exceeds 12,000 ft. and contains Cambrian to Triassic rocks overlying the Precambrian basement. Lower to Upper Precambrian rocks are exposed on part of the Upper Peninsula as part of the Wisconsin Arch. Sedimentary sequences dip off the basement high to the southeast into the Michigan Basin and to the northwest into the lake superior syncline.

A thick sequence of glacial drift (Pleistocene in age), over several hundred feet deep, overlies the older rocks throughout most of the State. Most of Michigan's ground water supply is obtained from these sediments. Water from deeper horizons becomes increasingly more saline because of the presence of evaporite beds.

A thick basal sandstone sequence that contains the Mt. Simon Formation represents a fair aquifer along the borders to the Michigan Basin, but is believed to become tighter and less permeable at greater depths.

V. RESOURCE DATA

Thermal gradient data indicate values in excess of $1.5^{\circ} \mathrm{F} /$ $100 \mathrm{ft}$. The deeper parts of the Basin do not correspond with large demographic centers; however, Grand Rapids and Lansing coincide with basement contours of 7000 to $8000 \mathrm{ft}$. The $2.0^{\circ} \mathrm{F} /$ $100 \mathrm{ft}$. gradient near Grand Rapids may produce water near $200^{\circ} \mathrm{F}$.

VI. GEOTHERMAL ACTIVITY

See Gruy Report $(\mathrm{C}-16)$.

VII. LEGAL ACTIVITIES

To be determined. 


\section{CONTACTS}

1. Department of Natural Resources, Ralph A. MacMullan, Director, (517) 373-1220.

2. Department of Natural Resources, Environmental Protection Branch, Ralph W. Purdy, Deputy Director, (517) $373-2682$.

3. Department of Commerce, Office of Energy Policy, Richard Helmbrecht, Director, (517) 373-8290.

4. Bureau of Budget, Planning and Policy Analysis Div., Thomas Clay, Director, (517) 373-7560.

5. Geological Survey, Arthur E. Slaughter, State Geologist, (517) 373-1256.

\section{REFERENCES AND LIST OF SIGNIFICANT REPORTS}

Common references only, see below.

\section{COMMON REFERENCES}

$(C-4),(C-6),(C-7)$, and $(C-16)$. 


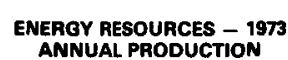

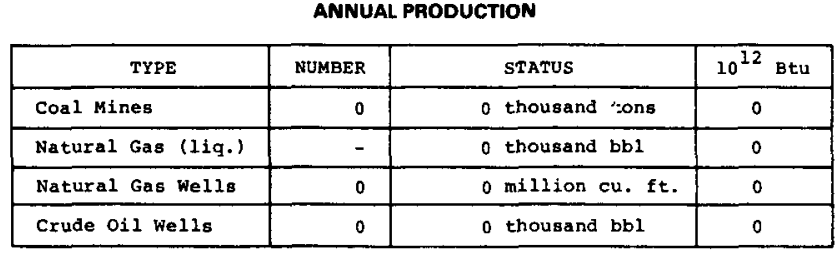

ENERQY USE - 1976 (10" BTU
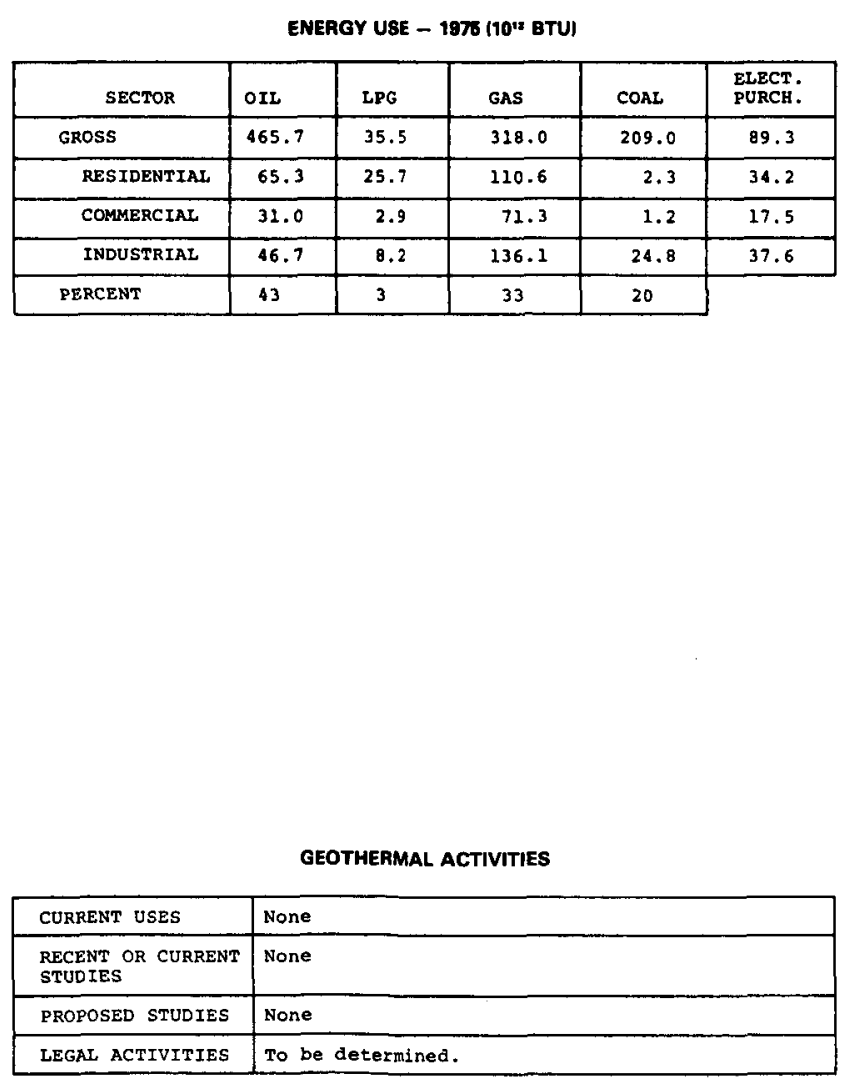

MINNESOTA
GEOTHERMAL DATA SUMMARY SHEET

$$
\text { (cf. State Geothernal Fact Sheet, Minnesota) }
$$

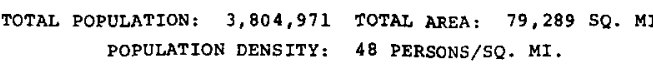

GEOTHERMAL OVERVIEW There is a very thin cover of sedimentary rock wer the
crystalline basement complex. Only low geothermal gradients are known to exis. 
State Geothermal Fact sheet

MINNESOTA

I. DEMOGRAPHIC INFORMATION (1970) (C-4)

TOTAL STATE

Population: 3,804,971 Area: 79,289 sq. mi. Density: 48 per sq. mi.

GEOTHERMAL RESOURCE AREA

Population:

II. ENERGY CONSUMPTION*

录

GROSS

Residential

Area :

(1975) (C-7)

OIL
(million
bbl)

Commerical

Industrial

83
11
5
8

8

LPG
(million
gal.)

GAS
(trillion
cu.ft.)

386

269

29

86

107

Trillion Btu

\begin{abstract}
GROSS
Residential

Commercial

Industrial
\end{abstract}

Percentages

$$
\begin{array}{r}
465.7 \\
65.3 \\
31.0 \\
46.7
\end{array}
$$

43

$\begin{array}{rr}35.5 & 318.0 \\ 25.7 & 110.6 \\ 2.9 & 71.3 \\ 8.2 & 136.1\end{array}$

3

33
338

114

90

sq. mi .

Density:

per sq. mi.
COAL (million tons)
209.0
2. 3
1.2
24.8

11

0.1

0.06

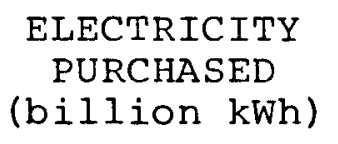

ELECTRICITY PURCHASED (billion kWh)

26

10

11

89.3

34.2

17.5

37.6

20

*Excluding nuclear and hydro electricity, coking coal and petroleum coke, and other petroleum products not used as fuels. 
III. STATE FUEL PRODUCTIION (1973) (C-6)

Type Number
Units

0 thousand tons

0 thousand $\mathrm{bbl}$

$0 \mathrm{million} \mathrm{cu}$. ft.

0 thousand bbl
Trillion Btu

Coal mines Natural gas (liq.)

Natural gas wells

Crude oil wells

$\begin{array}{ll}0 & 0 \text { thousand tons } \\ - & 0 \text { thousand bbl } \\ 0 & 0 \text { million cu. ft. } \\ 0 & 0 \text { thousand bbl }\end{array}$

0

0

0

0

IV. GEOLOGY

To be supplied.

V. RESOURCE DATA

To be supplied.

VI. GEOTHERMAL ACTIVITY

API trip report (1).

VII. IEGAL ACTIVITIES

None

VIII. CONTACTS

1. Department of Environmental Protection, State Planning Agency, Joseph Sizer, Director Environmental Planning, (612) $296-3985$.

2. State Planning Agency, Roger Wililams, Manager, (612) 296-2633.

3. Geological Survey, Dr. Matt S. Waton, Director, (612) 373-3372.

REFERENCES AND LIST OF SIGNIFICANT REPORTS

(1) "Visit to the State of Minnesota, 5 October 1976," APL/JHU QM-76-133, 15 Oct 1976 (see list of reports in this report).

COMMON REFERENCES

$(C-4),(C-6)$, and $(C-7)$. 


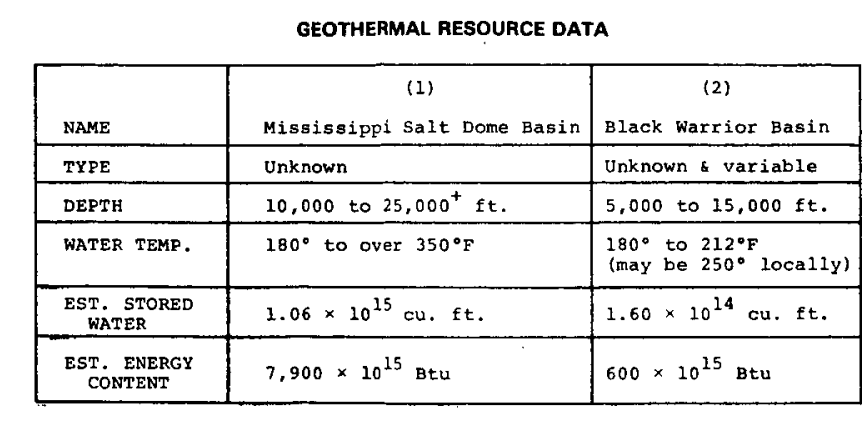

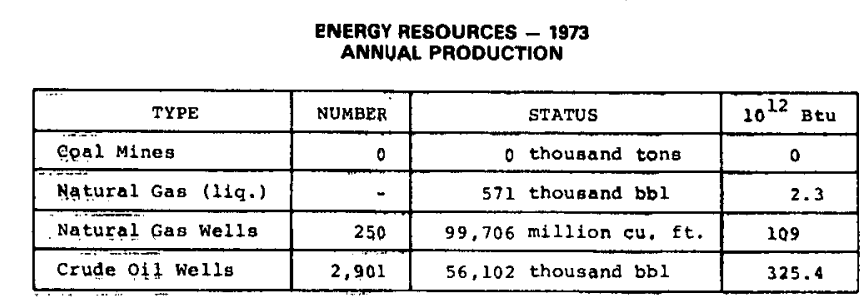

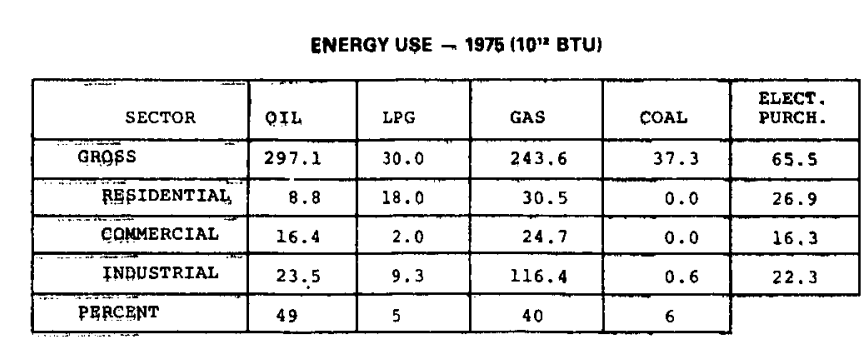

\begin{tabular}{|c|c|}
\hline \multicolumn{2}{|r|}{ GEOTHERMAL ACTVITIES } \\
\hline CURRENT USES & None \\
\hline $\begin{array}{l}\text { RECENT OR CURRRNT } \\
\text { STUDTISS }\end{array}$ & 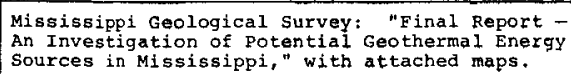 \\
\hline PROPOSES & None \\
\hline LEGAL ACTIVITIES & \begin{tabular}{|l|l|l|} 
Mone \\
\end{tabular} \\
\hline
\end{tabular}

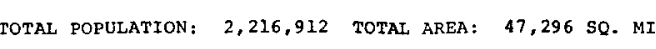

POPULATION DENSTTY: 47 PERSONS/SQ. MI.

\section{GEOTHERMAL OVERVIEW}

The Coastal Plain area of the state contains a thick seepresent a hydrothermal resource. There is some ev-

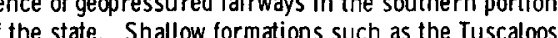
ormation represent moderate temperature. shallow. hy-

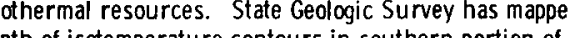

- Hot Spring

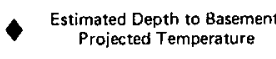

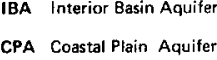
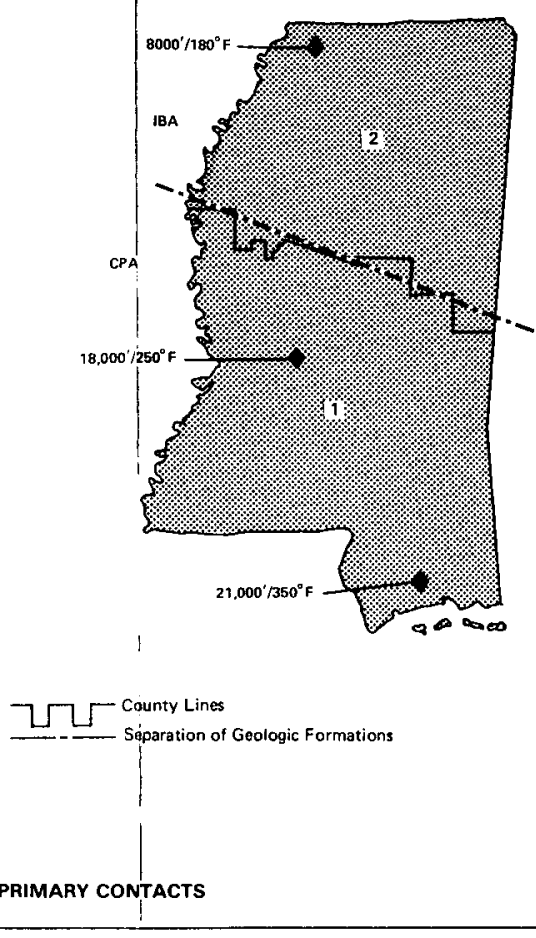

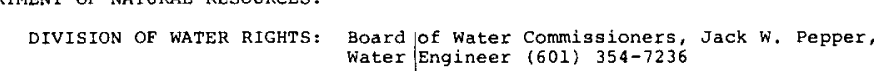

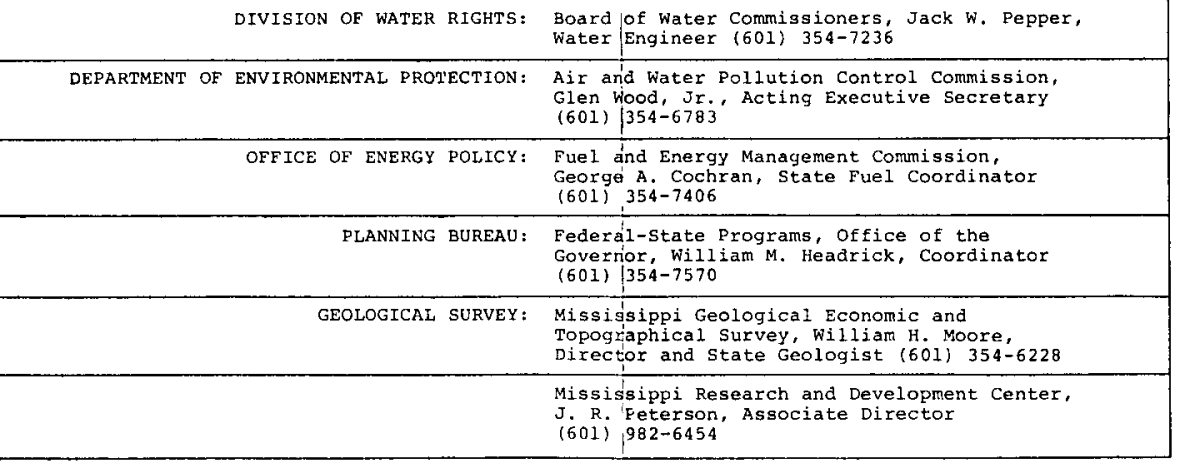

LEGILATIVE CONTACTS

\begin{tabular}{|c|c|}
\hline $\begin{array}{l}\text { SENARrors } \\
\text { John C. Stennis (D) } \\
\text { Thad Cochran }\end{array}$ & GOVERNOR Wi11iam F. Winter (D) \\
\hline $\begin{array}{l}\text { CONGRBSSNEN (DIST.) } \\
1 \text { - Jamic L. Whitten (D) }\end{array}$ & \\
\hline 2 - David R. Bowen (D) & \\
\hline $\begin{array}{l}4-\text { Jon Rinson }(R) \\
5-\text { Trent } \text { rott (R) }\end{array}$ & \\
\hline
\end{tabular}




\section{State Geothermal Fact sheet}

\section{MISSISSIPPI}

I. DEMOGRAPHIC INFORMATION (1970) (C-4)

TOTAL STATE

Population: 2,216,912 Area: $47,296 \mathrm{sq} \cdot \mathrm{mi}$. Density: 47 per sq. $\mathrm{mi}$. GEOTHERMAL RESOURCE AREA

Population: 2,216,912 Area: $47,296 \mathrm{sq} \cdot \mathrm{mi}$. Density: 47 per sq. mi.

II. ENERGY CONSUMPTION* (1975) (C-7)

\begin{tabular}{|c|c|c|c|c|c|}
\hline & $\begin{array}{l}\text { OIL } \\
\text { (million } \\
\text { bbl) }\end{array}$ & $\begin{array}{l}\text { LPG } \\
\text { (million } \\
\text { gal.) }\end{array}$ & $\begin{array}{l}\text { GAS } \\
\text { (trillion } \\
\text { cu.ft.) }\end{array}$ & $\begin{array}{l}\text { COAL } \\
\text { (million } \\
\text { tons) }\end{array}$ & $\begin{array}{l}\text { ELECTRICITY } \\
\text { PURCHASED } \\
(\mathrm{billion} \mathrm{kWh})\end{array}$ \\
\hline $\begin{array}{l}\text { GROSS } \\
\text { Residential } \\
\text { Commerical } \\
\text { Industrial }\end{array}$ & $\begin{array}{r}53 \\
2 \\
3 \\
4\end{array}$ & $\begin{array}{r}314 \\
188 \\
21 \\
97\end{array}$ & $\begin{array}{r}236 \\
30 \\
24 \\
113\end{array}$ & $\begin{array}{l}2 \\
0 \\
0 \\
0.02\end{array}$ & $\begin{array}{r}19 \\
8 \\
5 \\
7\end{array}$ \\
\hline \multicolumn{6}{|c|}{ Trillion Btu } \\
\hline $\begin{array}{l}\text { GROSS } \\
\text { Residential } \\
\text { Commercial } \\
\text { Industrial }\end{array}$ & $\begin{array}{r}297.1 \\
8.8 \\
16.4 \\
23.5\end{array}$ & $\begin{array}{r}30.0 \\
18.0 \\
2.0 \\
9.3\end{array}$ & $\begin{array}{r}243.6 \\
30.5 \\
24.7 \\
116.4\end{array}$ & $\begin{array}{r}37.3 \\
0.0 \\
0.0 \\
0.6\end{array}$ & $\begin{array}{l}65 \cdot 5 \\
26 \cdot 9 \\
16 \cdot 3 \\
22.3\end{array}$ \\
\hline Percentages & 49 & 5 & 40 & 6 & \\
\hline
\end{tabular}
*Excluding nuclear and hydro electricity, coking coal and petroleum coke, and other
petroleum products not used as fuels. 
III. STATE FUEL PRODUCTION (1973) (C-6)

Type Number Units Btu

Coal mines

Natural gas (liq.)

Natural gas wells

Crude oil wells

\author{
0 \\ 250 \\ $2,9.01$
}

- thousand tons

571 thousand bbl

99,706 million cu. ft.

56,102 thousand bbl
0

2.3

109

325.4

IV. GEOLOGY (1)

Mississippi may be divided into two resource areas. The northern portion of the state is part of the Black Warrior Basin that also extends into Alabama. Sediment thicknesses vary from 6,000 to 15,000 ft., averaging 10,000 ft. over much of this area. Geothermal gradients range from near-normal to well-above-normal

$\left(1.7^{\circ} \mathrm{F} / 1.00 \mathrm{ft}\right.$. or greater) in northern Mississippi. Temperatures at the bottom of the sedimentary pile should be from 150 to $210^{\circ} \mathrm{F}$ with local hot spots of up to $250^{\circ} \mathrm{F}$. Provided that deep formations have sufficient porosities and permeabilities, significant geothermal resources may exist in the old sediments of the Black warrior Basin.

In the second resource area, it appears that a sizeable abnormally pressured geothermal resource may be found in the Mississippi Salt Dome Basin, which lies in the south central part of the state. In addition to potential geopressured-geothermal resources, the salt Dome Basin contains numerous salt domes. Some think that the interiors of the salt pillars should show high temperatures because of the high thermal conductivity of salt and the contact of some pillars with the deep hot salt beds. Another potential energy source in the salt Dome Basin is the heat from igneous intrusions, one of the largest being the jackson Dome under Jackson, Mississippi. These buried plutons may still be at elevated temperatures and the heat may be trapped by the overlaying sedimentary deposits. The thick sediments in Mississippi extend to depths in excess of $25,000 \mathrm{ft}$. The porosity is expected to be high enough to yield sufficient water at great depths to be suitable resources. Geothermal gradients fluctuate locally but appear to be about normal with somewhat higher values in localized areas of central Mississippi. Temperatures in excess of $210^{\circ} \mathrm{F}$ should be experienced at depths of $10,000 \mathrm{ft}$. or more in any location exhibiting near-normal or higher geothermal gradients. 
V. RESOURCE DATA

1. BLACK WARRIOR BASIN

Type aquifer: unknown \& variable Area: 19,400 sq. mi. Depth: 5,000 to 15,000 ft. Avg. thickness:

Porosity: unknown Transmissivity:

Water temperature: 180 to $212^{\circ} \mathrm{F}$ (up to $250^{\circ} \mathrm{F}$ locally)

Recharge rate:

Estimate of water stored in aquifer: $1.60 \times 10^{14} \mathrm{cu} f t$. Estimate of energy content of water: about $600 \times 10^{15} \mathrm{Btu}^{\dagger}$

2. MISSISSIPPI SALT DOME BASIN

Type aquifer: unknown + Area: 27,917 sq. mi. Depth: 10,000 to $25,000^{+}$ft. Avg. thickness:

Porosity: unknown Transmissivity:

Water temperature: $180^{\circ} \mathrm{F}$ to in excess of $350^{\circ} \mathrm{F}$

Recharge rate:

Estimate of water stored in aquifer: $1.06 \times 10^{15} \mathrm{cu}$. ft.

Estimate of energy content of water: $7,900 \times 10^{15} \mathrm{Btu}^{\dagger}$

tAbove $120^{\circ} \mathrm{F}$, referenced to $90^{\circ} \mathrm{F}$; $10 \%$ porosity assumed, about 4.5 times this amount in rock.

VI. GEOTHERMAL ACTIVITY

Recent studies: Mississippi Geological Survey: "Final Report - An Investigation of Potential Geothermal Energy Sources in Mississippi," with attached maps.

VII. LEGAL ACTIVITIES

None

VIII. CONTACTS

1. Mississippi Geological, Economic, and Topographical Survey, $2525 \mathrm{~N}$. West St., P. O. Drawer 4915, Jackson, MS 39216, William H. Moore, Director \& State Geologist, (601) 354-6228. 
2. Fuel and Energy Management Commission, 1307 Woolfolk State Office Bldg., Jackson, MS 39.20.5, George A. Cochran, State Fuel Coordinator, (601) 354-7406.

3. Mississippi Research \& Development Center, Jackson, MS 39205, J. R. Peterson, Associate Director, (601) $982-6454$.

4. Board of Water Commissioners, Jack W. Pepper, Water Engineer, (601) 354-72:36.

5. Air and Water Pollution Control Commission, Glen Wood, Jr., Acting Executive Secretary, (601). 354-6783.

6. Federal-State Programs, Office of the Governor, William M. Headrick, Coordinator, (601) 354-7570.

REFERENCES AND LIST OF SIGNIFICANT REPORTS

(1) W. J. Toth and F. C. Paddison, "Pre-Scenario Visit to Mississippi," APL/JHU QM-77-159, 12 Dec 1977.

(2) S. S. Papadopulos, R. H. Wallace, Jr., J. B. Wesselman, and R. E. Taylor, "Assessment of Onshore GeopressuredGeothermal Resources in the Northern Gulf of Mexico Basin," Assessment of Geothermal Resources of the United states, USGS Circular 726, 1975.

(3) Executive Reference Map No. 305," Geomap Company 1977.

(4) W. J. Toth and F. C. Paddison, "Meeting with Dr. Ray Wallace, USGS/WR," APL/JHU QM-78-010, 25 Jan 1978.

(5) J. R. Peterson, Computer Printout of Industries in Mississippi, 1 Dec 1977.

COMMON REFERENCES

$(c-1),(c-2),(c-3),(c-4),(c-5),(c-6)$, and $(c-7)$. 
EOTHERMAL DATA SUMMARY SHEET

ENERRY RESOURCES - 1975
ANNUAL PRODUCTON

\begin{tabular}{|c|c|c|c|}
\hline TYPE & NUMBER & stratus & $10^{12} \mathrm{Btu}$ \\
\hline Coal Mines & 10 & 4,657 thousand tons & 101.5 \\
\hline Naturat Gas (11iq.) & & 0 thousand bb1 & \\
\hline Natural Gas wel1s & 2 & 3 & 0.0 \\
\hline Crude 011 we11s & 135 & 60 thousand bb1 & 0.3 \\
\hline
\end{tabular}

TOTAL POPULATTON: 4, 676,501 TOTAL AREA: 68,995 SQ. M.

POPULATION DENSITY: 68 PERSONS/SQ. MI.

GEOTHERMAL OVERVIEW

Relatively shallow sedimentary cover and low gradients
reduce the likelihood of explotitable resources in Missour.

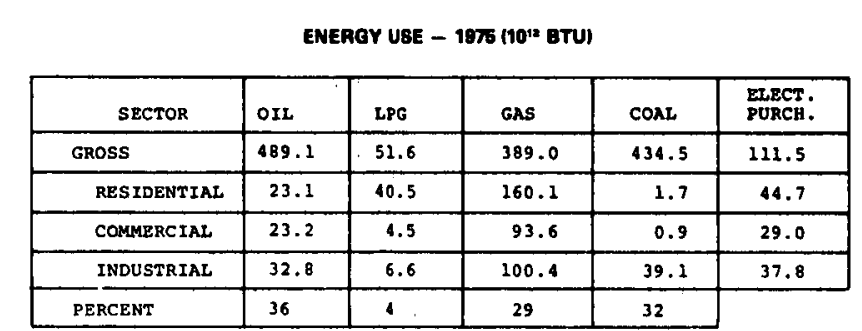

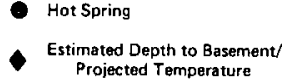

CPA Cossta Pan AAvition

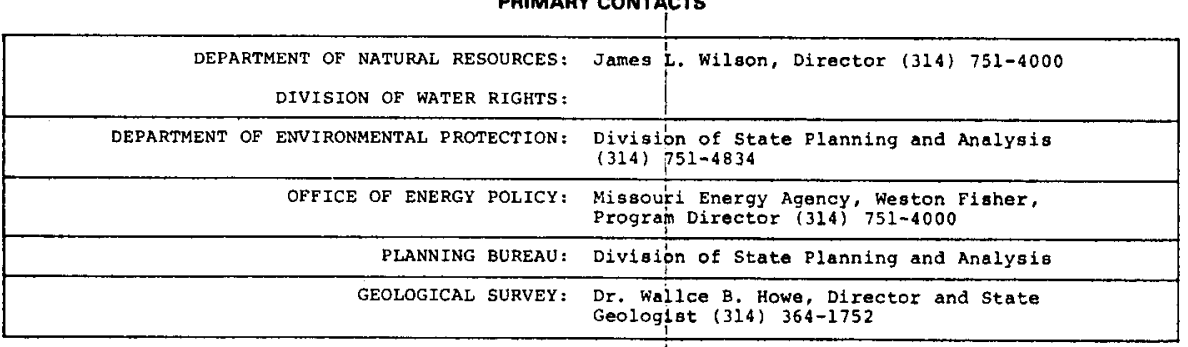

of State Planning and Analys

LEGisLative CONTACTS

\begin{tabular}{|c|c|}
\hline $\begin{array}{ll}\text { SENAXORS } & \text { Thomas F. Eagleton (D) } \\
\text { John C. Danforth (R) }\end{array}$ & COVERNOR Christopher S. Bond (R) \\
\hline CONGRESSWEN (DIST.) & \\
\hline 1 - william L. Clay (D) & \\
\hline $\begin{array}{l}\text { - Robert A. Young (D) } \\
3 \text { - Richard A. Gephardt (D) }\end{array}$ & \\
\hline $\begin{array}{l}4-\text { The Skelton (D) } \\
5 \text { - Richard Bolling (D) }\end{array}$ & \\
\hline $\begin{array}{l}\text { 6- E. Thonas colenan (R) } \\
7 \text { - Gene raylor }(R)\end{array}$ & \\
\hline $\begin{array}{l}8-\text { wendel11 Bailey (R) } \\
9-\text { Harold L. Volkmer (D) }\end{array}$ & \\
\hline 10- Bil1 Enerson (R) & \\
\hline
\end{tabular}



III. STATE FUEL PRODUCTION (1973) (C-6)

Type Number Units $\begin{gathered}\text { Trillion } \\ \text { Btu }\end{gathered}$

Coal mines

Natural gas (liq.)

Natural gas wells

Crude oil wells
10
4,657 thousand tons

0 thousand bbl

33 milition cu. ft.

60 thousand bbl
101.5

0

0.0

0.3

IV. GEOLOGY

See reference list (1):

V. RESOURCE DATA

Recent seismic activity and the relative highs in the silica geotemperatures in ground water near New Madrid, MO, suggests the possibility for a deep fluid circulation system with geothermal potential $(C-6)$.

VI. GEOTHERMAL ACTIVITY

None known, but see (1).

VII. LEGAL ACTIVITIES

None known.

VIII. CONTACTS

1. Department of Natural Resources, James L. Wilson, Director, (314) 751-4000.

2. Division of State Planning and Analysis, (314) 751-4834.

3. Missouri Energy Agency, Weston Fisher, Program Director, (314) 751-4000.

4. Division of State Planning and Analysis.

5. Geological Survey, Dr. Wallce B. Howe, Director and state Geologist, (314) 364-1752.

REFERENCES AND LIST OF SIGNIFICANT REPORTS

(1) Renner, J. I. and Vaught, Tracy I." Geothermal Resources of the Eastern United States, DOT/ET/28373-T2, Gruy Federal, Inc., Arlington, VA. 
THE JOHNS HOPKINS UNIVERSITY

APPLIED PHYSICS LABORATORY

LAUAEL, MAFYLAND

\section{COMMON REFERENCES}

$(C-4),(c-6)$, and $(C-7)$.

MO-3 


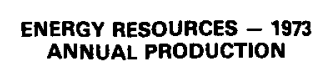

\begin{tabular}{|c|c|c|c|}
\hline TYPE & NOMBER & StRaUUS & $10^{12} \mathrm{Btu}$ \\
\hline Coal 1 mines & 9 & 10,725 thousand tons & 228.8 \\
\hline Natural Gas (11q.) & - & 679 thousand $\mathrm{bbl}$ & 2.7 \\
\hline Natura1 Gas we11s & 1,118 & 56,175 million cu. ft. & 61.4 \\
\hline Crude oil wel1s & 3,471 & 34,620 thousand bb1 & 200.8 \\
\hline
\end{tabular}

ENERGY USE - 1975 (10" BTU)

\begin{tabular}{|c|c|c|c|c|c|}
\hline \multicolumn{6}{|c|}{ 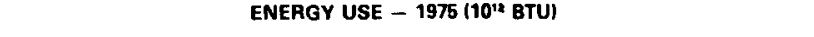 } \\
\hline SECTroR & OIL & LPG & GAS & COAL & $\begin{array}{l}\text { LuECr. } \\
\text { PUCCAH: }\end{array}$ \\
\hline GRoss & \begin{tabular}{|l|l|}
128.4 \\
\end{tabular} & 5.5 & 83.7 & 26.3 & 30.3 \\
\hline RESIDENTIAL & 5.9 & 4.1 & 24.9 & 0.1 & 7.0 \\
\hline COMMERCIAL & 17.5 & 1.4 & 78.7 & 0.1 & 24.7 \\
\hline INDUSTRRAL & 27.1 & 0.8 & 36.7 & 0.7 & 17.4 \\
\hline PERCENT & 53 & 3 & 37 & 7 & \\
\hline
\end{tabular}

GEOTHERMAL ACTIVTTIES

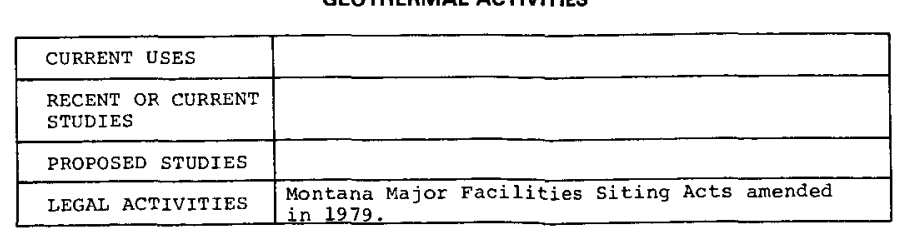

\section{GEOTHERMAL DATA SUMMARY SHEET}

TOTAL POPULATION: 742,500 TOTAL AREA: 147,138 SQ. M. POPULATION DENSTTY: 5.0 PERSONS/SQ. MI

\section{GEOTHERMAL OVERVIEW}

The Northern Rocky Mountain and the Middle Rocky

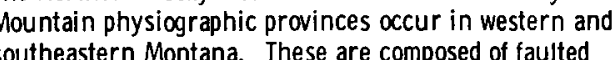

and folded sedimentary rocks and intrusive rocks that

lorm mountain bloks

low to moder ate temperatures and most of the hot springs

in the state. North central and eastern Montana is in

with its yet undeterermined potential for direct heat appli-

with hts yet undeterm
cations, is in this area.

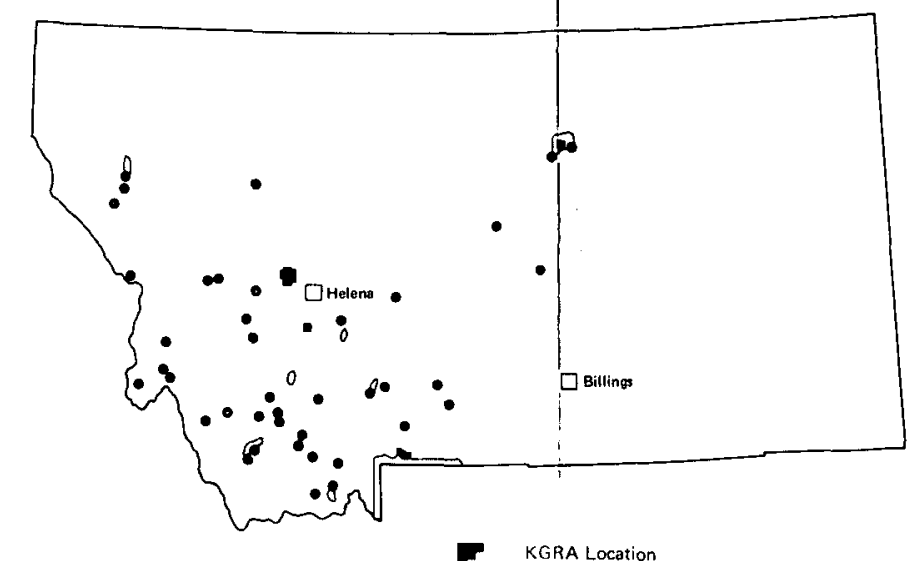

F KGra Location

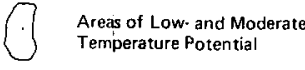

... Hot sorings

PRIMARY CONTACT

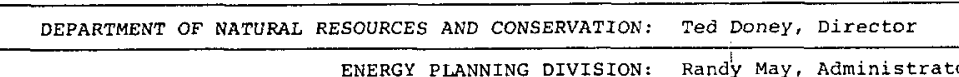

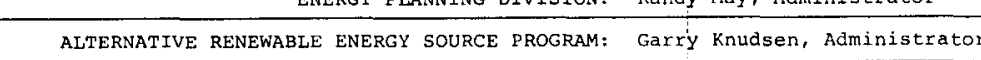

DERARTMENT OF HEALTH AND ENVIROONAENATA, SERVYCESS: Arthur C. Knight, M.D., Director

STARB GBOTEN MONTANA BUREAU OF MTNES: Sid Groff, Director

OfERAT ToNS RESERRCH: Ranay Moy (montana Dept. of Natural

RESOURCE ASEESSMENT: $\begin{aligned} & \text { Johnh Sonderegger (Montana Bureau of Mines } \\ & \text { and Geologyy) }\end{aligned}$

LEGILATIVE CONTACTS

\begin{tabular}{|c|c|}
\hline $\begin{array}{l}\text { Sohnan Melcher (D) } \\
\text { Sax Baucus (D) }\end{array}$ & GOVERNOR Ted Schwinden (D) \\
\hline $\begin{array}{l}\text { CONGRESSMEN (DIST.) } \\
1 \text { - Pat Willi ams (D) } \\
\text { 2- Ron Marienee (R) }\end{array}$ & \\
\hline
\end{tabular}



III STATE FUEL PRODUCTION (1973)

$(c-6)$

Type

Coal mines

Natural gas (liq.)

Natural gas wells

Crude oil wells
Number

9
1,118
3,471

Units

$$
\begin{aligned}
& 10,725 \text { thousand tons } \\
& 679 \text { thousand bbl } \\
& 56,175 \text { million cu. ft. } \\
& 34,620 \text { thousand bbl }
\end{aligned}
$$

Trillion

Btu

228.8

2.7

$6 \cdot 1.4$

200.8

IV. GEOLOGY

The Northern Rocky Mountains and Midale Rocky Mountains physiographic provinces underlie roughly half of Montana from the northern border toward the west to the southern border toward the east. Faulted and folded sedimentary rocks as well as intrusive rocks form mountain blocks and intermontane basins. The Boulder Batholith is in southwestern Montana and is a large intrusion dated at 68 to 74 million years in age. Much of this area shows higher than normal heat flow and numerous hot springs. Geochemical well- and spring-temperature observations suggest low or moderate temperature resources that could be suited to direct heat applications. The Great Plains province occurs in the rest of the state. The east is underlain by part of the Madison aquifer.

\section{RESOURCE DATA}

Three KGRAs are defined in Montana. West Yellowstone is expected to be a high temperature $\left(>300^{\circ} \mathrm{F}\right)$ resource, but that is not confirmed as yet. Corwin, just outside the Yellowstone park, and Marysville, near Helena, are confirmed to be low to moderate $\left(<300^{\circ} \mathrm{F}\right)$ resources. Eight other sites are also confirmed reservoirs in this temperature range. A number of other sites, including the broad area of the Madison aquifer, are considered to be likely prospects for low to moderate temperature waters.

VI. GEOTHERMAL ACTIVITY

DOE selected the Warm Springs state Hospital PON proposal (1978) for design, construction, and operation of a space heating system. Resource evaluation was conducted (1979) by the Montana Energy Research and Development office and the MHD R\&D Institute, Inc.

The total average of six noncompetitive leasers on federal land was 10,687 (March 1979). No competitive leasers in KGRAs have been awarded and no state land has been leased. 
A number of test wells, ranging from $200 \mathrm{ft}$. to $6,600 \mathrm{ft}$. have been drilled in four western counties.

Exploratory activities in eight western counties include gravity, geology, resistivity, seismic, magnetic, heat flow surveys, and gradient hole drilling. USGS performed ideal flow and formation mapping in the the area of the Madison aquifer (eastern Montana) from 1977 to 1979.

Twelve counties, all but one in the Rocky Mountains Province, have operating hydrothermal systems. In addition to spas and swimming pools these projects include space heating of houses, resort cabins, and one complex of a large warehouse and shops. A subdivision of 100 to 300 units in Lewis and Clark county is to use hydrothermal space heating if disposal problems can be recorded.

VII. LEGAI ACTIVITIES

The Montana Major Facilities Siting Act includes geothermal production provisions. This act was amended in 1979 lowering the energy production limits to $50 \mathrm{MW}$ for electricity and $25 \times 10^{6}$ Btu/hr for geothermal; the term "direct use" is not stated explicitly.

\section{CONTACTS}

1. Department of Natural Resources and Conservation, Ted Doney, Director.

2. Energy Planning Division, Randy May, Administrator.

3. Alternative Renewable Energy Source Program, Garry Knudsen, Administrator.

4. Department of Health and Environmental Services, Arthur C. Knight, M.D., Director.

5. Montana Bureau of Mines, Sid Goff, Director.

6. State Geothermal Team:

a. Operations Research, Randy Moy (Montana Dept. of Natural Resources).

b. Resource Assessment, John Sonderegger (Montana Bureau of Mines and Geology). 


\section{REFERENCES AND LIST OF SIGNIFICANT REPORTS}

(1) "Montana Hyarothermal Commercialization Baseline," EG\&G Idaho Inc., Jun 1979.

(2) Keith E. Brown, "Geothermal Energy in Montana: Site Data Base and Development Status," Geo-Heat Utilization Center, Klamath Falls, OR, Nov 1979.

\section{COMMON REFERENCES}

$(C-4),(c-6)$, and $(C-7)$. 
EEERQY RESOUACES - 1979
ANNUAL PROOUCTION

\begin{tabular}{|c|c|c|c|}
\hline TYPE & NUMBERR & STAtus & $10^{12} \mathrm{Btu}$ \\
\hline Coal Mines & 0 & 0 thousand tons & \\
\hline Natura1 Gas (1iq.) & & 357 thousand bb1 & 1.4 \\
\hline Natural Gas We $11 \mathrm{~s}$ & 29 & 3,836 million cu. ft. & 4.2 \\
\hline Crude oil wel1s & 1,107 & 7,240 thousand bb1 & 42.0 \\
\hline
\end{tabular}

ENERAY USE - 1975 10" BTU1
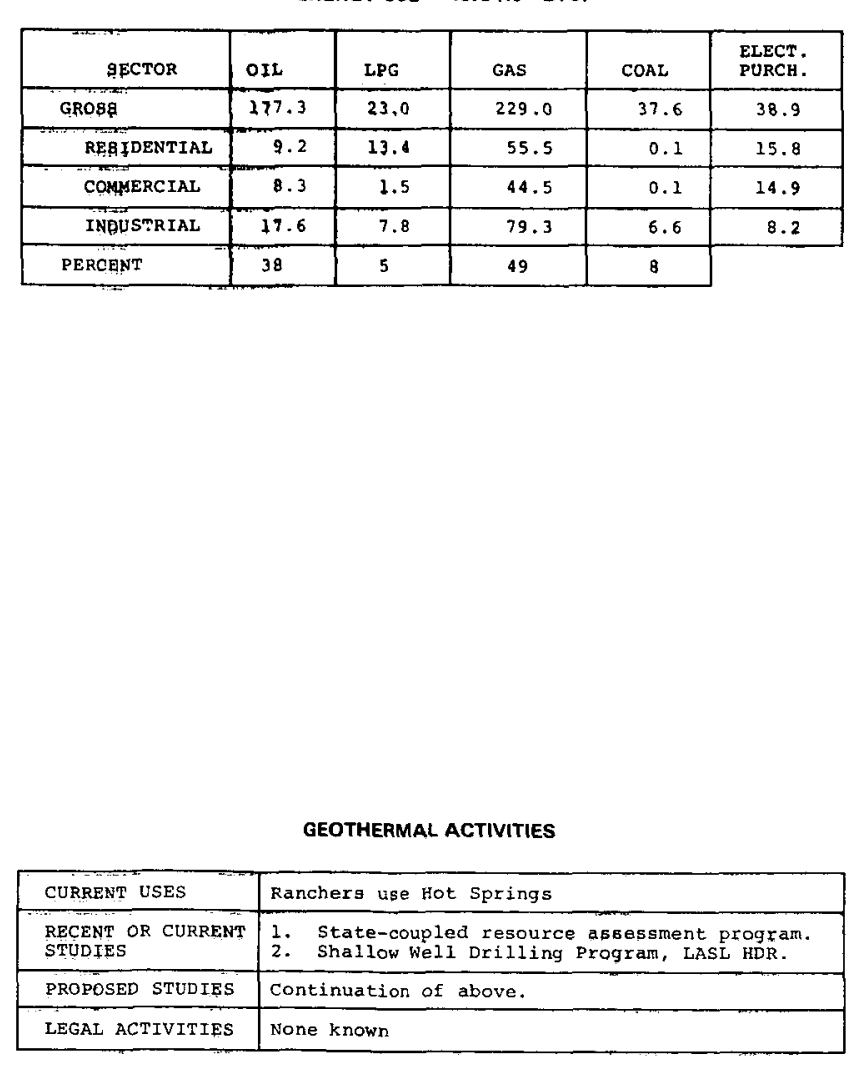

NEBRASKA
GEOTHERMAL DATA SUMMARY SHEET

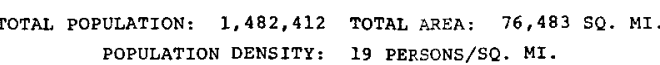

GEOTHERMAL OVERVIEW

A significant area shows higher than normal thermal
gradient. Basement depth reaches several thousand feet gradient. Basement depth reach

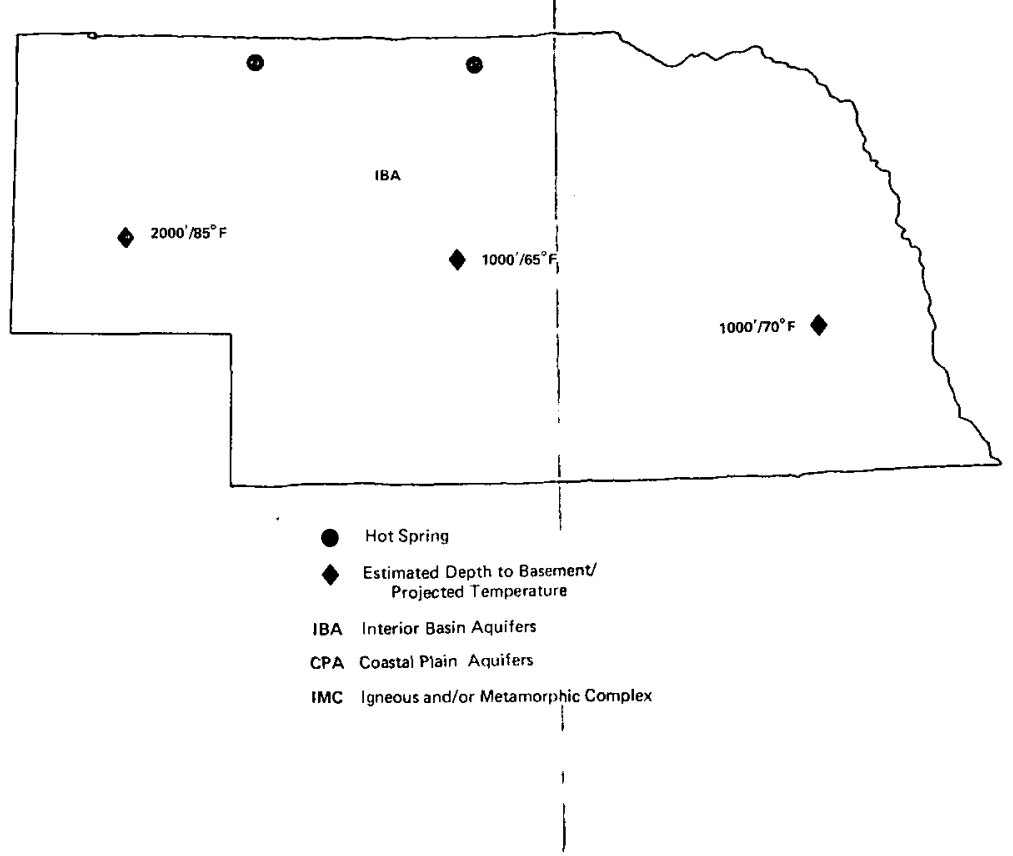

pamary CONTÁcts

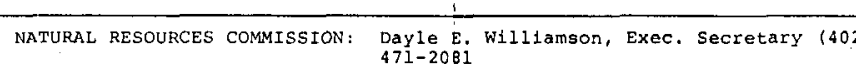
STATE ENBRGY OFFICE: Wil11 ian Pa1mer, Di rector, (402) 471-2867

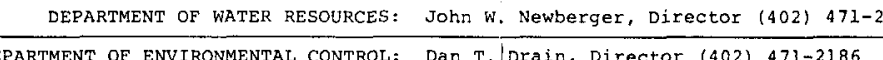

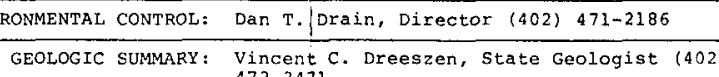

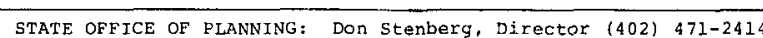

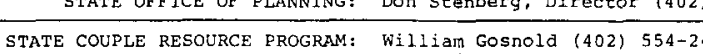

Legsarve contacts

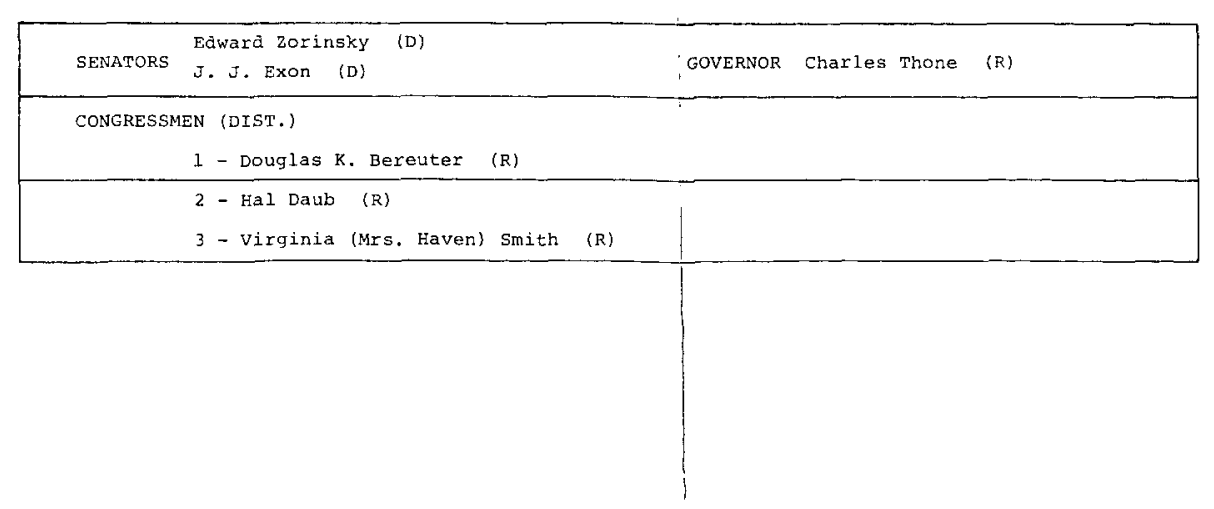


State Geothermal Fact sheet

NEBRASKA

I. DEMOGRAPHIC INFORMATION (1970) (C-4)

TOTAL STATE

Population: 1,482,412 Area: 76,483 sq. mi. Density: 19 per sq. mi.

GEOTHERMAL RESOURCE AREA

Population:

\section{Area:}

sq. $\mathrm{mi}$.

Density:

per sq. mi.

II. ENERGY CONSUMPTION*

(1975) (C-7)

畓

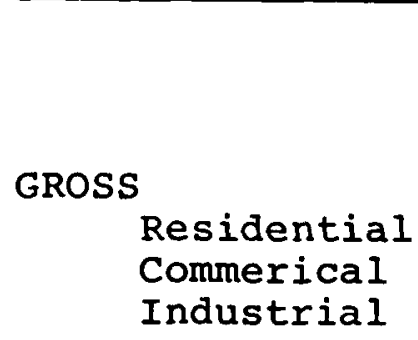

$$
\begin{gathered}
\text { OIL } \\
\text { (million } \\
\text { bbl) }
\end{gathered}
$$

33

2

1

Industrial

GROSS
Residential
Commercial
Industrial

Percentages

177.3
9.2
8.3
17.6

38

$$
\text { LPG }
$$
(million

GAS
(trilion
cu.ft.)

241

140

16

82

222

54

43

77

Trillion Btu

$$
\begin{array}{r}
23.0 \\
13.4 \\
1.5 \\
7.8
\end{array}
$$

5

$$
\begin{array}{r}
229 \cdot 0 \\
55.5 \\
44.5 \\
79.3
\end{array}
$$

49

\section{COAL \\ (million \\ tons)}

2

0.00

0.00

0.3

$$
\begin{array}{r}
37.6 \\
0.1 \\
0.1 \\
6.6
\end{array}
$$

8
ELECTRICITY

PURCHASED

(billion kWh)

11
5
4
2

38.9

15.8

14.9

8.2 *Excluding nuclear and hydro electricity, coking coal and petroleum coke, and other
petroleum products not used as fuels. 
III. STATE FUEL PRODUCTION (1973) $(\mathrm{C}-6)$

Type Number Units $\begin{gathered}\text { Trillion } \\ \text { Btu }\end{gathered}$

Coal mines

Natural gas (liq.)

Natural gas wells

Crude oil wells

\author{
0 \\ $\overline{2}$ \\ 1,107
}
0 thousand tons
357 thousand bbl
3,836 million cu. ft.
7,240 thousand bbl

0
1.4
4.2
42.0

IV. GEOLOGY

Nebraska lies the so-called "Central Stable" geologic region of the U.S. The depth to basement varies from about $1000 \mathrm{ft}$. in the eastern to over $6000 \mathrm{ft}$. in the southwestern part of the state. A faulted zone, the Nemaha Uplift, crosses the southeastern part of Nebraska; the Denver Basin underlies the southwestern part of the Nebraska panhandle. The Nemaha Uplift is the locus. of epicenters for mild seismic activity.

V. RESOURCE DATA

About 13,000 oil and gas well holes have been drilled in the state, concentrated in the western part where the deeper sedimentary stratra lie (1). It is inferred that most of these holes are nonproducing, the logging records providing the permanent data. only recently (1) has an attempt been made to fill in more completely the geothermal gradient information contained on the AAPG Geothermal Gradient Map of North America (C-1). The results of 10 heat-flow measurements in the state as well as a refined thermal gradient map are given in (1). Areas in the western, northern, and southwestern parts of the state show gradients higher than $2^{\circ} \mathrm{F} / 100 \mathrm{ft}$. and a large part of the state shows a gradient in excess of $1.8^{\circ} \mathrm{F} / 100 \mathrm{ft}$. Little is known of the hydrology of the deep aquifers. Oil wells into the Chadron and Cambridge Arches (which run northwest just west of central Nebraska) pump some water. The Madison Aquifer extends into Nebraska under these arches, but no information on water quantity or quality is available.

VI. GEOTHERMAI ACTIVITY

There is a State Coupled Resource Assessment Program under the direction of the University of Nebraska. This program has completed information on the oil and gas wells in the state and the calculated heat flow for a few sites. Using measurements from old and a limited number of newly drilled wells, this effort has produced some refinement of the AAPG geothermal map and future plans consider the use of Bouguer gravity mapping and chemical 
THE JOHNS HOPKINS UNIVERSITY

APPLIED PHYSICS LABORATORY

LAUPEL, MARYLAND

geothermometry. As part of the LASL Hot Dry Rock Program, a limited amount of gradient drilling has been done and is planned.

VII. LEGAL ACTIVITIES

None known.

VIII. CONTACTS

1. State Energy Office, Box 95085, Lincoln, NE 68509, William Palmer, Director, (402) 471-2867.

2. Department of Water Resources, 301 Centennial Mall, Iincoln, NE 68509, John W. Newberger, Director, (402) $471-2363$.

3. Department of Environmental Control, 301 Centennial Mall, S., Lincoln, NE 68509, Dan J. Drain, Director; Gene Robinson, Air and Water Pollution Control, (402) $471-2186$.

4. Geologic Survey, University of Nebraska, 113 Nebraska Hall, Iincoln, NE 65588, Vincent C. Dreeszen, State Geologist; Marvin Carlson, State Coupled Reservoir Assessment Program, (402) 472-3471.

5. State office of Planning and Programming, Box 94601, State Capitol, Lincoln, NE 68509, Don Stenberg, Director, (402) 471-2414.

6. Natural Resources Commission, 301 Centennial Mall, Lincoln, NE 68509.

7. State Coupled Resource Program, Dept. of Geography and Geology, University of Nebraska - Omaha, Omaha, NE 68182, William Gosnold (also see item 4 above), (402) 554-2457.

8. Public Service Commission, 301 Centennial Mall, S., Lincoln, NE 68504, Everett W. Green, Secretary, (402) 471-3101.

\section{REFERENCES AND LIST OF SIGNIFICANT REPORTS}

(I) W. D. Gosnold, Jr., "Geothermal Studies, Nebraska," (Chapter XXIV of common reference $\mathrm{C}-8$ ).

(2) J. C. Maxwell, "The Hot Dry Rock Eastern Program," (Chapter VIII of common reference $\mathrm{C}-8$ ). 
(3) "Visit to state of Nebraska," APL/JHU QM-76-134, 15 oct 1976.

(4) "Geothermal Resources of the Eastern United States," Gruy Federal, Inc., Arlington, VA, Report for DOE, DOE/ET/28373-T2 .

COMMON REFERENCES

$(c-1),(c-4),(c-6),(c-7)$, and $(c-8)$. 
ENEREY RESOURCES - 1975
ANNUAL POODECTION
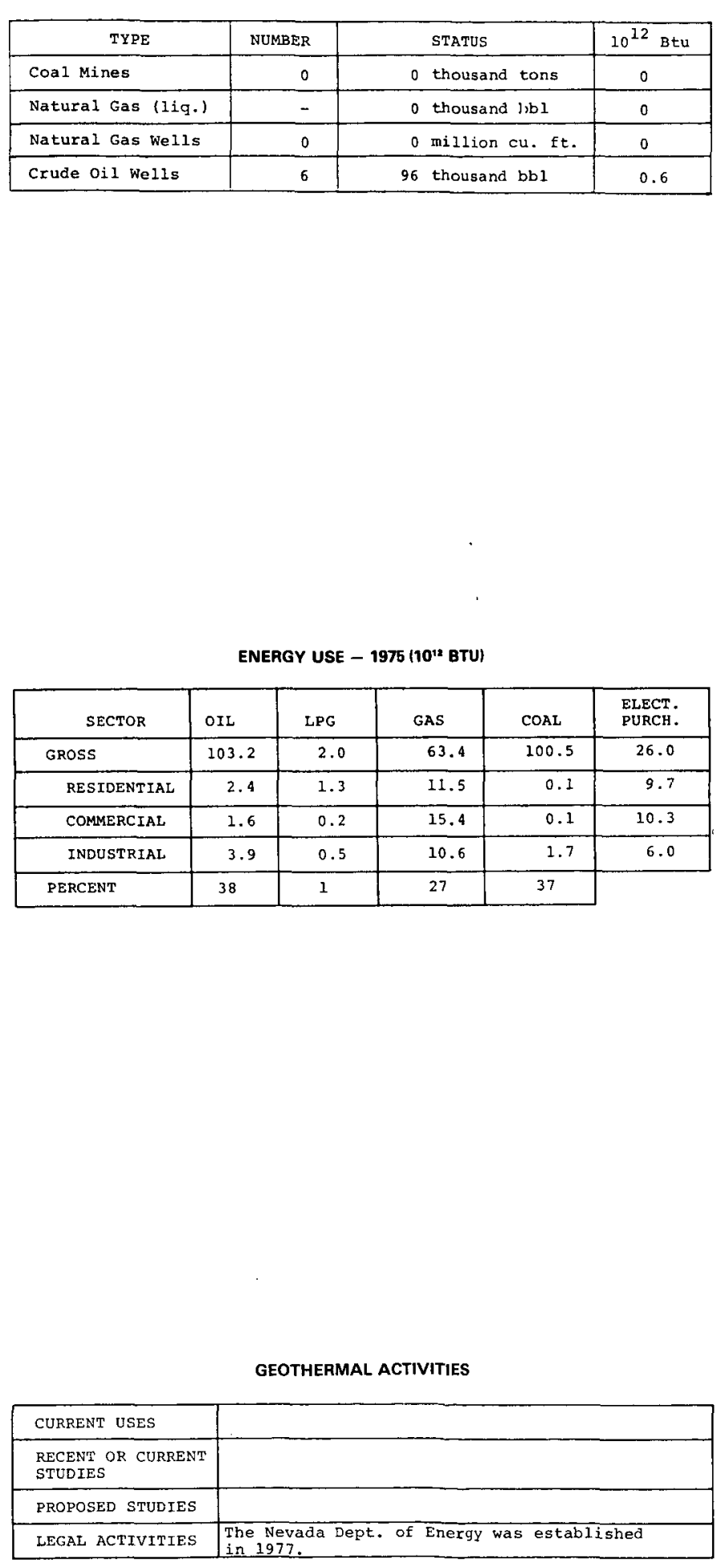

NEVADA
GEOTHERMAL DATA SUMMARY SHEET

TOTAL POPULATION: 488,738 TOTAL AREA: 110,540 SQ. M

GEOTHERMAL OVERVIEW

Northern Nevada displays consider able potential for geo-
thermal develoment Thity KGRAs are identified an

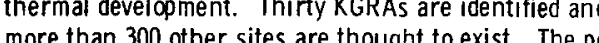

sible generation of electricity from geothersal resours-

sible generation of electricity from geenher
is being investigated at seven location

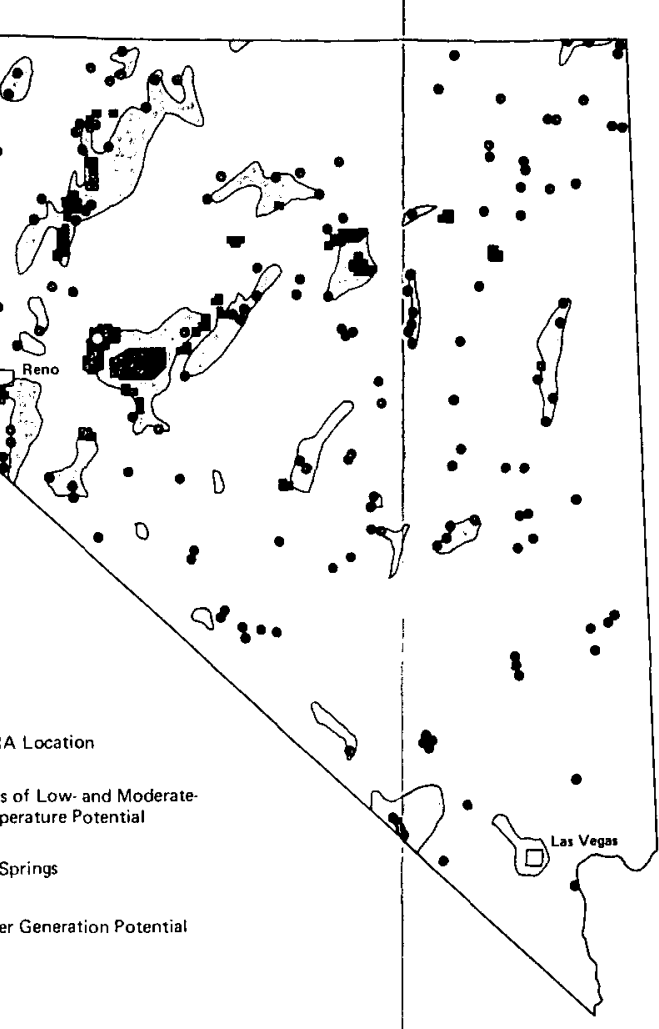

mari contacts

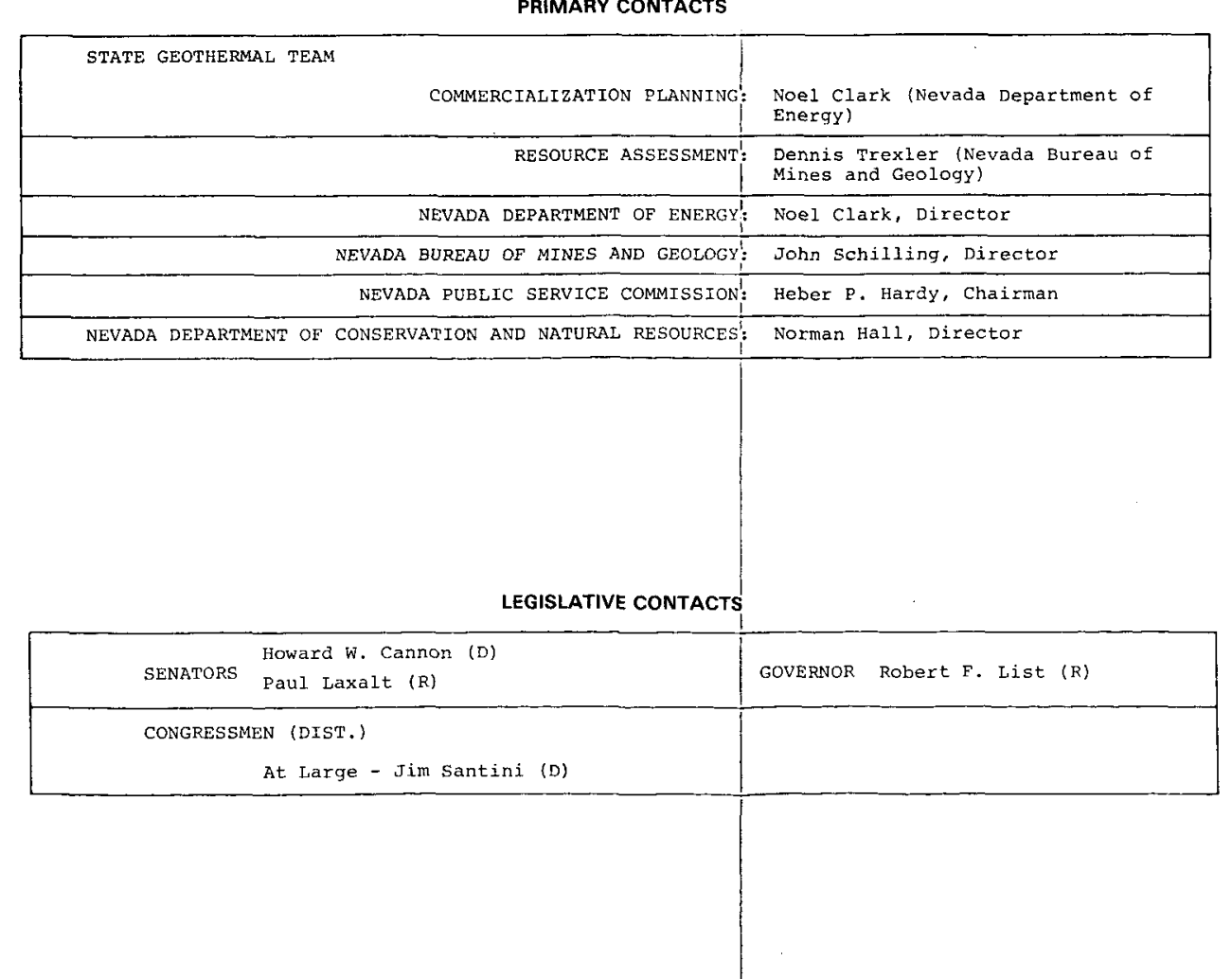


State Geothermal Fact sheet

NEVADA

I. DEMOGRAPHIC INFORMATION (1970) (C-4)

TOTAL STATE

Population: 488,738 Area: $110,540 \mathrm{sq} \cdot \mathrm{mi}$. Density: 4.4 per sq. mi.

GEOTHERMAL RESOURCE AREA

Population:

II. ENERGY CONSUMPTION*

Area :

sq. mi.

Density:

per sq. mi.

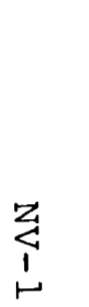

GROSS

Residential

Commerical

Industrial

(1975) (C-7)

OII
(million
bbl)

LPG

(million

19

19
0
0

0

1

21

21
14

2

Giss
(trilion
cu.ft.)

COAL
(million
tons)

61

11

15

Trillion Btu

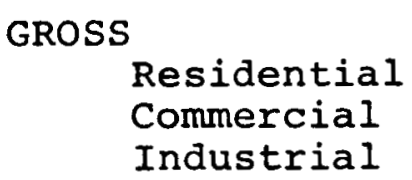

GROSS

Residential

Commercial

Industrial

Percentages

$$
\begin{array}{r}
103.2 \\
2.4 \\
1.6
\end{array}
$$

38

$\begin{array}{ll}2.0 & 63.4 \\ 1.3 & 11.5 \\ 0.2 & 15.4 \\ 0.5 & 10.6\end{array}$

1

5
0
0
0

ELECTRICITY

PURCHASED

(billion kWh)

*Excluding nuclear and hydro electricity, coking coal and petroleum coke, and other petroleum products not used as fuels. 
III. STATE FUEL PRODUCTION (1973) (C-6)

Type Number

Units

0 thousand tons

0 thousand $\mathrm{bbl}$

0 million cu. ft.

96 thousand $\mathrm{bbl}$
Trillion

Btu

\section{0}

0

0

0.6

IV. GEOLOGY

Nevada lies almost entirely within the Basin and Range physiographic province. This province is characterized by northward-trending mountain blocks separated by alluvial-filled basins. Mountain and valley blocks are separated by faults with vertical displacements of up to 9 or 10 thousand feet. Deep circulating water along these faults is thought to be the source of many warm springs and wells, especially in the northern half of the state. Several areas are known to contain young volcanic rocks and it is expected that other such areas will be found. At least two of the known hydrothermal systems, Steamboat Springs and Silver Peak, are thought to be related to igneous activity. Heat flow throughout the tectonically active Basin and Range province is high; it is especially high near Battle Mountain in the northern part of Nevada. In addition, northern Nevada contains numerous springs and wells whose geochemical thermomentry indicates high reservoir temperatures. Thirty sites have been designated as KGRAs, over 300 more sites are believed to have exploitable geothermal potential.

V.

\section{RESOURCE DATA}

Desert Peak in the Brady-Hazen KGRA has been confirmed as a high temperature reservoir. Seven more sites are believed to qualify. Four sites have been confirmed as low or moderate reservoirs. There are many more prospects.

VI.

\section{GEOTHERMAL ACTIVITY}

About 753,000 acres of federal land have been leased for geothermal purposes.

Two PONs were awarded (1978) in Nevada: one in Elko to demonstrate space heating of commercial buildings and one in Reno to retrofit an apartment complex with geothermal heating.

Geothermal Food Processors, Inc. started operating a food dehydration facility in 1979. This project was backed by a DOE guaranteed loan. 
DOE/State and Industry Couples Programs are active at thirteen sites. These programs are providing data from existing holes as well as new gradient holes and deeper exploratory ones.

Thirty-six sites are included in the DOE/State geothermal planning process.

VII. IEGAL ACTIVITIES

The Nevada Department of Energy was established by 1977 legislation. Pending legislation (1979) deals with taxation of geothermal resources, products, and by-products.

VIII. CONTACTS

1. State Geothermal Team:

a. Commercialization Planning, Noel Clark (Nevada Department of Energy);

b. Resource Assessment, Dennis Trexler (Nevada Bureau of Mines and Geology).

2. Nevada Department of Energy, Noel Clark, Director.

3. Nevada Bureau of Mines and Geology, John Schilling, Director.

4. Nevada Public Service Commission, Heber P. Hardy, Chairman.

5. Nevada Department of Conservation and Natural Resources, Norman Hall, Director.

REFERENCES AND LIST OF SIGNIFICANT REPORTS

(1) "Nevada Hydrothermal Commercialization Baseline," EG\&G Idaho, Inc., Aug 1979.

COMMON REFERENCES

$(C-4),(C-6)$, and $(C-7)$. 

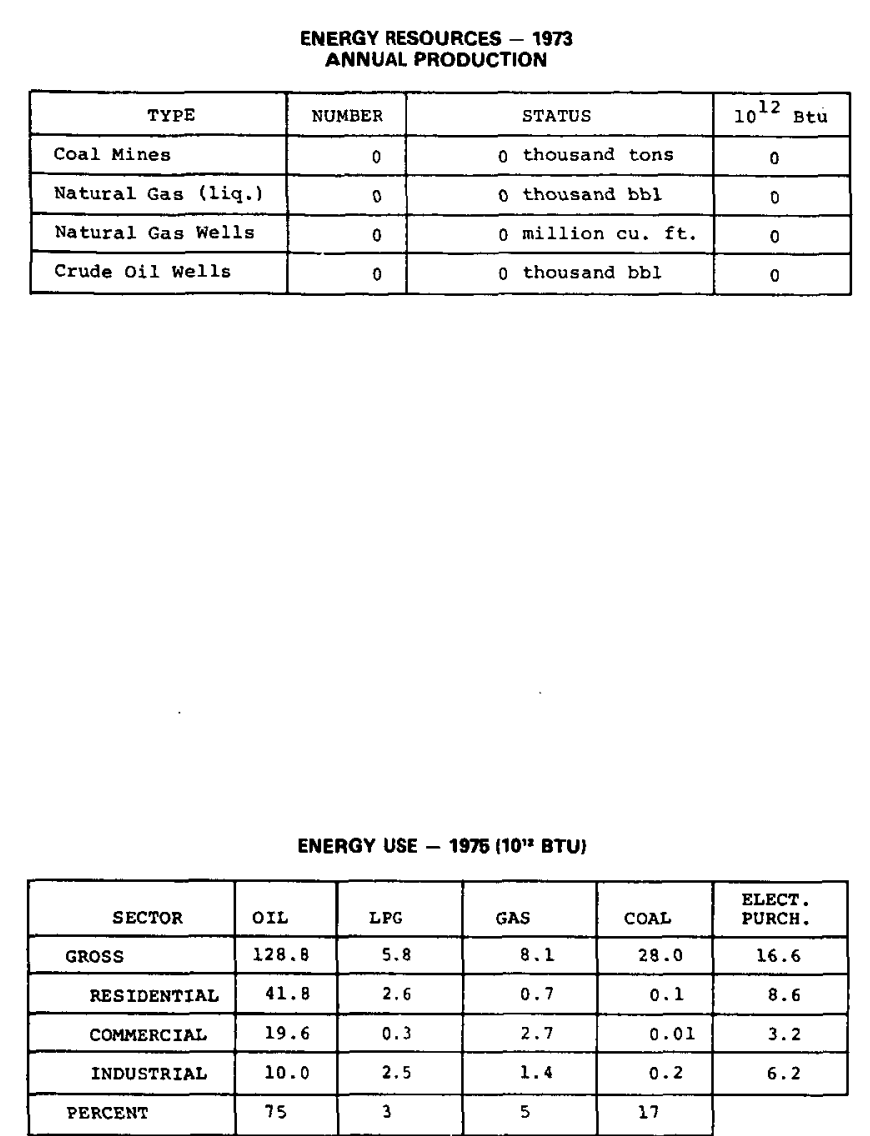

GEOTHERMAL ACTTVTIES

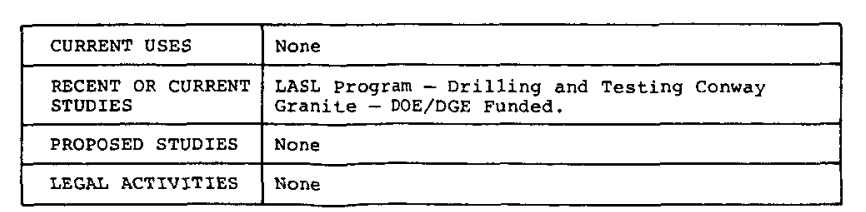

NEW HAMPSHIRE
GEOTHERMAL DATA SUMMARY SHEET

TOTRL POPULATION: 877,488 TORAL AREA: 9,027 S0. MI.

GEOTHERMAL OVERVIEW

Little sedimentary cover exists in this state; however, trations of rationctive elementis do cour across the stor and may have some future value.
- Estimated eeprt to Basement

IBA Inverio Basin Aauiter

IMC Igreous anditor Metamorophic Comp

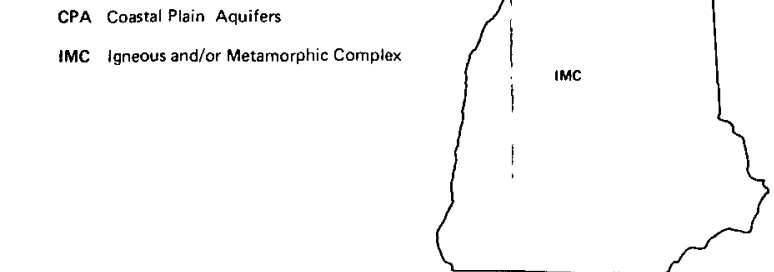

1

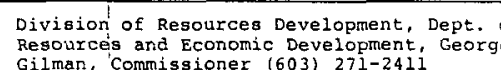
Water Reaurces Board, Gearge
hasairnan

\begin{tabular}{|c|c|}
\hline $\begin{array}{l}\text { DEPARTMENT OF NATURAL, RESOURCES: } \\
\text { DIVISTSON OF WATER RTCHTS: }\end{array}$ & 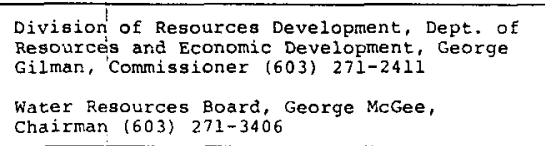 \\
\hline \multicolumn{2}{|l|}{ DEPARTUENT OF ENVYRONMENTAL PROTECTION: } \\
\hline OFFICE OF ENERGY POLICY: & 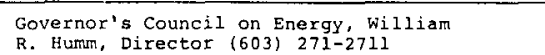 \\
\hline PLANNTMG BUREAU: & Ron Pol tak, Executive Dizector (603) $271-2155$ \\
\hline GEOLOGICAL SURVEY: & Roberert Davis, State Geologist (603) 862-17178 \\
\hline
\end{tabular}

LEGisLative CONTÁCTS

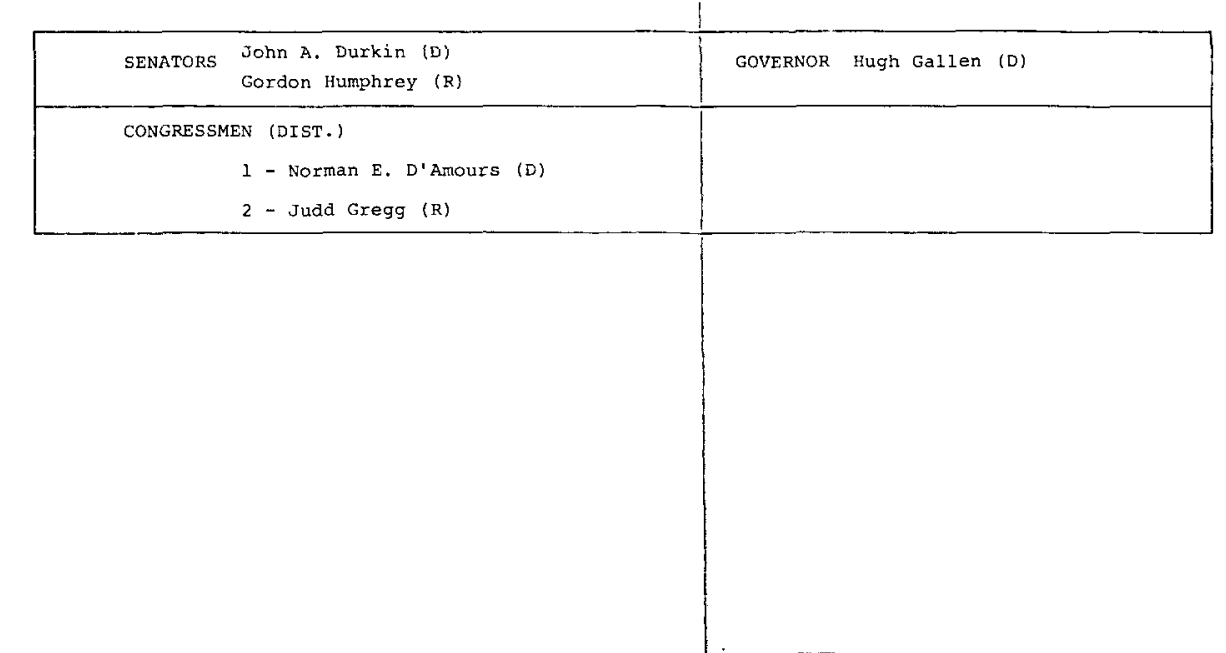


State Geothermal Fact Sheet

NEW HAMPSHIRE

I. DEMOGRAPHIC INFORMATION (1970) (C-4)

TOTAL STATE

Population: $\quad 877,488$ Area: $9,027 \mathrm{sq} \cdot \mathrm{mi}$. Density: $97.2 \mathrm{per} \mathrm{sq} \cdot \mathrm{mi}$.

GEOTHERMAL RESOURCE AREA

Population:

Area: sq. mi. Density: per sq. mi.

II. ENERGY CONSUMPTION* (1975) (C-7)

OIL LPG

LPG (million (miliion bbl) gal.)

GROSS

Residential

Commerical

Industrial

23

7

3

Industrial

60
27
3
26
GAS (trillion
cu.ft.)
8
0.7
3
COAL
(million
tons)

1

0.00

0.00

0.00

ELECTRICITY

PURCHASED

(billion kWh)

\section{Trillion Btu}
GROSS
Residential
Commercial
Industrial

Percentages

128.8
41.8
19.6
10.0

75

$\begin{array}{ll}5.8 & 8.1 \\ 2.6 & 0.7 \\ 0.3 & 2.7 \\ 2.5 & 1.4\end{array}$

3
5

$$
\begin{gathered}
28.0 \\
0.1 \\
0.01 \\
0.2
\end{gathered}
$$

16.6

8.6

3.2

6.2

17

*Excluding nuclear and hydro electricity, coking coal and petroleum coke, and other petroleum products not used as fuels. 
III. STATE FUEL PRODUCTION $(1973)(C-6)$

Type Number

Units

Trillion Btu.

Coal mines

Natural gas (Iiq.)

0

0 thousand tons

0

Natural gas wells

0 thousand $\mathrm{bbl}$

o mililion cu. ft.

crude oil wells

0 thousand bbl

0

0

0

0

IV. GEOLOGY

New Hampshire is underlain by Paleozoic and Mesozoic metamorphic and igneous rocks. The highest heat flow belt (>1.8 HFU) in the East extends through this state. A group of Mesozoic igneous rocks, the White Moutain Magma series, have higher than average concentrations of radioactive material. However, no deep sedimentary basins exist to serve as insulation for areas of high heat flow. Because of weathering, this lack of insulation, and rare subsurface data, above average subsurface temperatures are not known to exist.

V. RESOURCE DATA

Not applicable at this time.

VI. GEOTHERMAL ACTIVITY

See references (1) and (2).

VII. LEGAL ACTIVITIES

Not applicable at this time.

VIII. CONTACTS

1. Division of Resources development, Dept. of Resources and Economic Development, George Gilman, Commissioner, (603) $271-2411$.

2. Water Resources Board, George McGee, Chairman, (603) 271-3406.

3. Governor's Council on Energy, William R. Humm, Director, (603) 271-2711.

4. Planning Bureau, Ron Poltak, Executive Director, (603) 271-2155. 
5. Geological Survey, Robert Davis, State Geologist, (603) 862-1718.

REFERENCES AND LIST OF SIGNIFICANT REPORTS

(1) "Hot Dry Rock Geothermal Energy Development Project, Anrual Report Fiscal Year 1977," Los Alamos Scientific Laboratory, LA-7109-PR.

(2) "Geothermal Energy \& New Hampshire," APL/JHU QM-76-108.

\section{COMMON REFERENCES}

$(\mathrm{C}-1),(\mathrm{C}-4),(\mathrm{C}-6)$, and $(\mathrm{C}-7)$. 


\section{G GEOTHERMAL DATA SUMM J}

ENEREY RESOURCES - 1973
ANNUAL PROOUCTION

\begin{tabular}{|c|c|c|c|}
\hline TYPE & NOMBER & STatus & $10^{12} \mathrm{Btu}$ \\
\hline Coal Mines & 0 & 0 thousand tons & 0 \\
\hline Natural Gas (11q.) & $\circ$ & 0 thousand bo 1 & 0 \\
\hline Natura1 Gas ke11s & $\operatorname{lo} 2-2$ & 0 mi 121 ion ou. $\mathrm{ft}$. & 0 \\
\hline Crude oil wel19 & $\circ$ & 0 thousand bb1 & 0 \\
\hline
\end{tabular}

ENERQY USE - 1955 10" BTU1

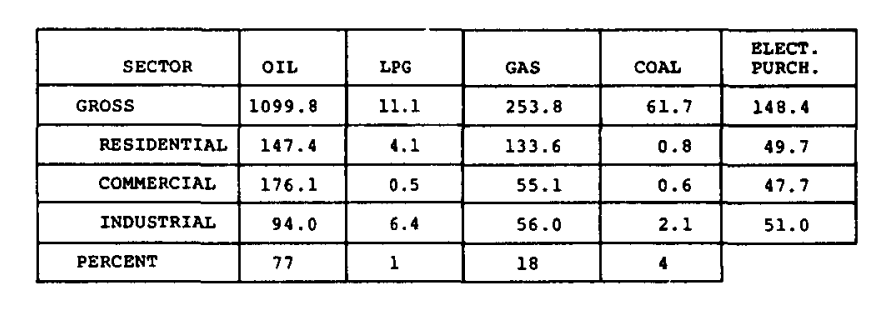

GEOTHERMAL ACTIVITIES

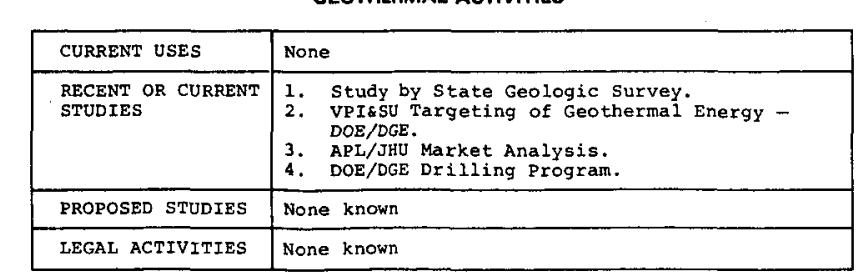

TOTAL POOULATION: 7,168, 164 TOTAL AREA: 7,521 SQ.

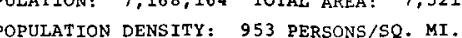

GEOTHERMAL OVERVIEW

The unconsolidated, water rich sediments of the Atlantic increase in thickness in the southeast to 6500 feet. An

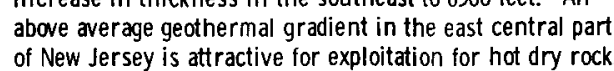
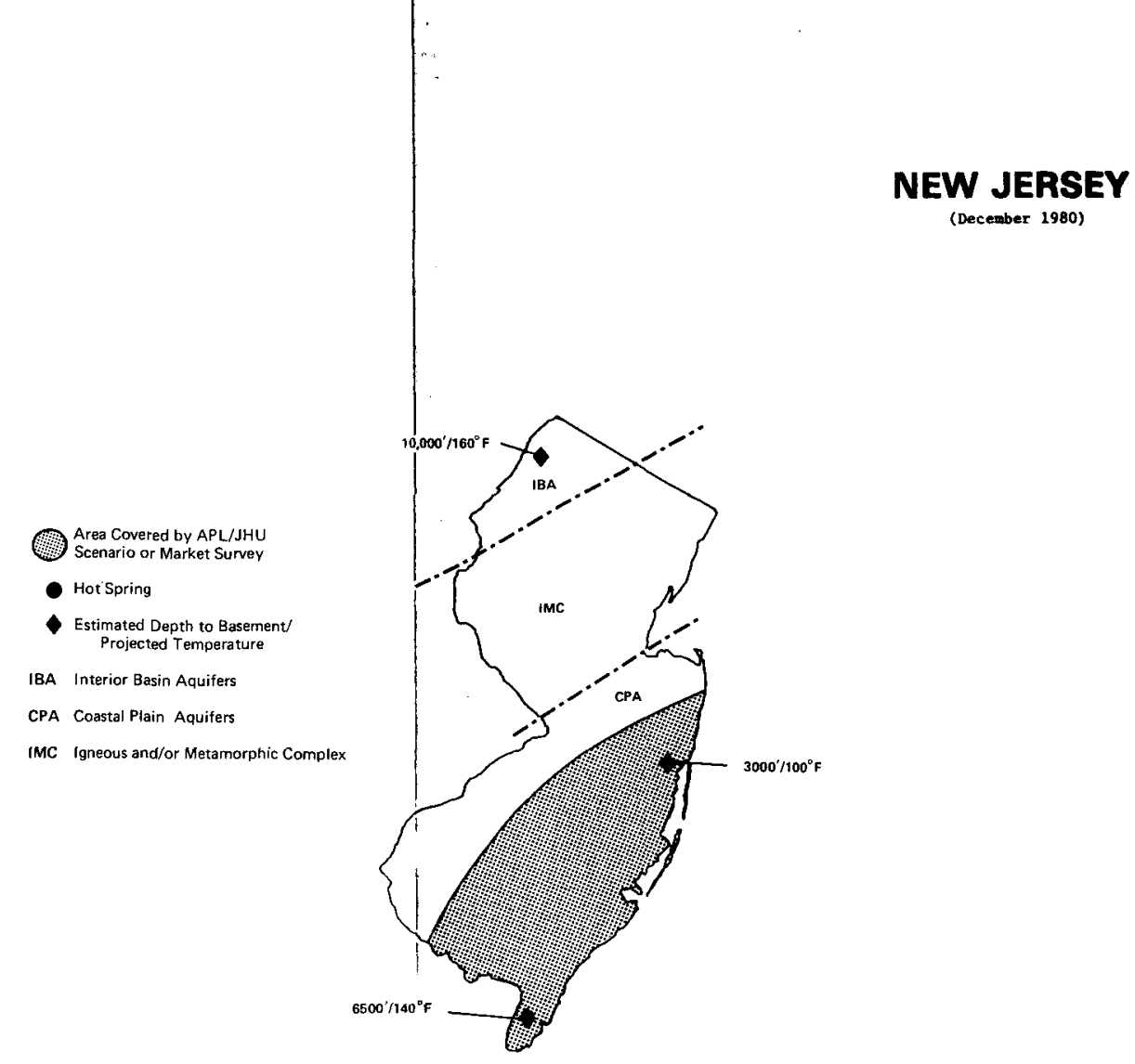

PRIMARY CONTACTS
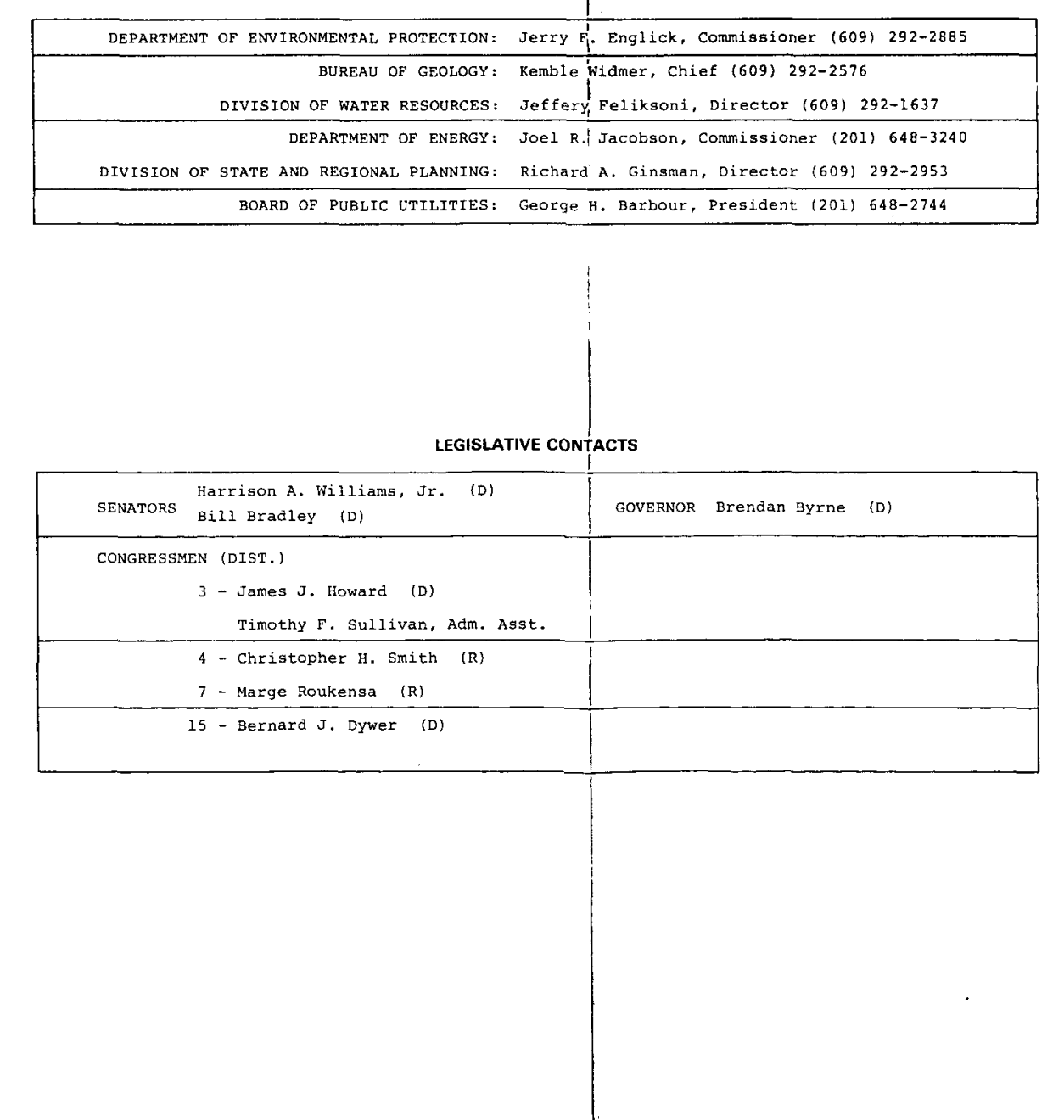
State Geothermal Fact sheet

NEW JERSEY

I. DEMOGRAPHIC INFORMATION (1970) (C-4)

TOTAL STATE

Population: 7,168,164 Area: 7,521 sq. mi. Density: 953 per sq. mi. GEOTHERMAL RESOURCE AREA

Population: 1,166,024 Area: 2,506 sq. mi. Density: 465 per sq. mi.

II. ENERGY CONSUMPTION* (1975) (C-7)

$\begin{array}{cccccc} & \begin{array}{c}\text { OIL } \\ \text { (million } \\ \text { bbl) }\end{array} & \begin{array}{c}\text { LPG } \\ \text { (million } \\ \text { gal.) }\end{array} & \begin{array}{c}\text { GAS } \\ \text { (trillion } \\ \text { cu.ft.) }\end{array} & \begin{array}{c}\text { COAL } \\ \text { (million } \\ \text { tons) }\end{array} & \begin{array}{c}\text { ELECTRICITY } \\ \text { PURCHASED } \\ \text { (billion kWh) }\end{array} \\ \text { GROSS } & 193 & 116 & 246 & 2.5 & 43 \\ \text { Residential } & 25 & 43 & 129 & 0.03 & 15 \\ \text { Commerical } & 30 & 5 & 53 & 0.02 & 14 \\ \text { Industrial } & 15 & 67 & 54 & 0.08 & 15\end{array}$

Trillion Btu

\begin{tabular}{|c|c|c|c|c|c|}
\hline $\begin{array}{l}\text { GROSS } \\
\text { Residential } \\
\text { Commercial } \\
\text { Industrial }\end{array}$ & $\begin{array}{r}1099.8 \\
147.4 \\
176.1 \\
94.0\end{array}$ & $\begin{array}{r}11.1 \\
4.1 \\
0.5 \\
6.4\end{array}$ & $\begin{array}{r}253.8 \\
133.6 \\
55.1 \\
56.0\end{array}$ & $\begin{array}{r}61.7 \\
0.8 \\
0.6 \\
2.1\end{array}$ & $\begin{array}{r}148.4 \\
49.7 \\
47.7 \\
51.0\end{array}$ \\
\hline Percentages & 77 & 1 & 18 & 4 & \\
\hline
\end{tabular}

*Excluding nuclear and hydro electricity, coking coal and petroleum coke, and other petroleum products not used as fuels. 
III. STATE FUEL PRODUCTION (1973) (C-6)

$\begin{array}{ccc}\text { Type Number Units } & \text { Trilion } \\ \text { Btu }\end{array}$

Coal mines

Natural gas (liq.)

Natural gas wells

Crude oil wells
0 thousand tons

0 thousand bbl

0 million cu. ft.

0 thousand bbl
0

0

0

0

\section{IV. $\quad$ GEOLOGY}

The coastal plain of New Jersey is underlain by sedimentary rocks of Mesozoic and Cenozoic age. These sedimentary accumulations form a wedge that thickens to the southeast and lies on a southeasterly sloping basement surface. The maximum depth to basement, approximately $6500 \mathrm{ft}$, occurs in Cape May County at the southern tip of the state (1). The lowermost sedimentary units in the southern half of the state are sandstones of very low permeability (2). The basement surface rises to the north ( $1500 \mathrm{ft}$. near Sandy Hook) in conjunction with an increase in both permeability and water quality in the overlying sediments.

A maximum geothermal gradient $\left(2.0^{\circ} \mathrm{F} / 100 \mathrm{ft.}\right)$ occurs along the central coastal region of the state in the vicinity of point Pleasant (3). The association and overlap of the elevated basement surface and high geothermal gradient may be related to an underlying pluton.

V. RESOURCE DATA

Before the DOE temperature gradient wells were drilled in 1978, it was known that several wells showed gradients in excess of $35^{\circ} \mathrm{C} / \mathrm{km}\left(1.9^{\circ} \mathrm{F} / 100 \mathrm{ft}.\right)$. In 1978 , five $1000 \mathrm{ft}$. holes were drilled as part of the DOE coastal plain drilling program (4) and the gradients were measured by VPI\&SU who estimated the temperatures at basement. This program confirmed the existence of somewhat higher than normal gradients in the central and north-central coastal plain; however, the higher gradients lie in regions where the basement is only about $2000 \mathrm{ft}$. deep. From (3), the maximum estimated basement temperature which occurs at Cape May at an estimated depth of $6500 \mathrm{ft}$. is $62^{\circ} \mathrm{C}$ or $143^{\circ} \mathrm{F}$, resulting from a near normal gradient in this limited area of relatively deep sedimentary strata. The regions of shallow sediments and above normal gradients may have possibilities as a hot dry rock source. 
VI. GEOTHERMAL ACTIVITY

The geothermal gradient test holes and the assessment of the data have been completed as part of the DOE/DGE East Coast arilling program. The APL study of potential energy markets in the resource area has been completed (5).

VII. LEGAL ACTIVITIES

None known.

VIII. CONTACTS

1. Department of Energy, 1100 Raymond Blvd., Newark, NJ 07102, Joel R. Jacobson, Commissioner, (201) 648-3290.

2. Bureau of Geology, Dept. of Environmental Protection, P.O. Box 1390, Trenton, NJ 08625, Kemble Widmer, Chief, (609) 292-2576.

3. Division of Water Resources, Department of Environmental Protection, P.O. Box 2809, Trenton, NJ 08625, Jeffery Feliksoni, Director, (609) 292-1637.

4. Department of Environmental Protection, P.O. Box 1390, Trenton, NJ 08625, Jerry F. English, Commissioner, (609) 292-2885.

5. Division of State and Regional Planning, P.O. Box 2768, 329 W. State Street, Trenton, NJ 08625, Richard A. Ginsman, Director, (609) 292-2953.

6. Board of Public Utilities, 101 Commerce Street, Newark, NJ 07102, George H. Barbour, President, (201) 648-2744.

7. State Coupled Geothermal Assessment Program, VPI\&SU, Blackburg, VA 24061, Prof. John Costain, (703) 961-5096.

REFERENCES AND LIST OF SIGNIFICANT REPORTS

(1) P. M. Brown, J. A. Miller, and F. W. Swain, "Structural and Stratigraphic Framework, and Spatial Distribution of Permeability of the Atlantic Coastal Plain, North Carolina to New York," U.S.G.S. Professional Paper 796, 1972 .

(2) "New Jersey and Geothermal Energy," APL/JHU QM-78-031, 20 Mar 1978. 
(3) "Evaluation and Targeting of Geothermal Energy Resources in the Southeastern United States," VPI\&SU, Blacksburg, VA, DOE Report No. VPI\&SU-5648-5, 30 Mar 1979.

(4) "Atlantic Coastal Plain Geothermal Test Holes, New Jersey," Gruy Federal, Inc., Houston, Texas, DOE Report No. NVD-1558-1.

(5) "Geothermal Energy Market Study in the Atlantic Coastal Plain, Definitions of Markets for Geothermal Energy in the Northern Atlantic Coastal Plain," JHU/APL GEM-002 (QM-80-075), May 1980 .

(6) "Geothermal Resources of the Eastern United States," Gruy Federal, Inc., Arlington, VA, U.S. DOE Report No. DOE/ET/28373-T2.

\section{COMMON REFERENCES}

$$
(c-1),(c-4),(c-6), \text { and }(c-7) \text {. }
$$




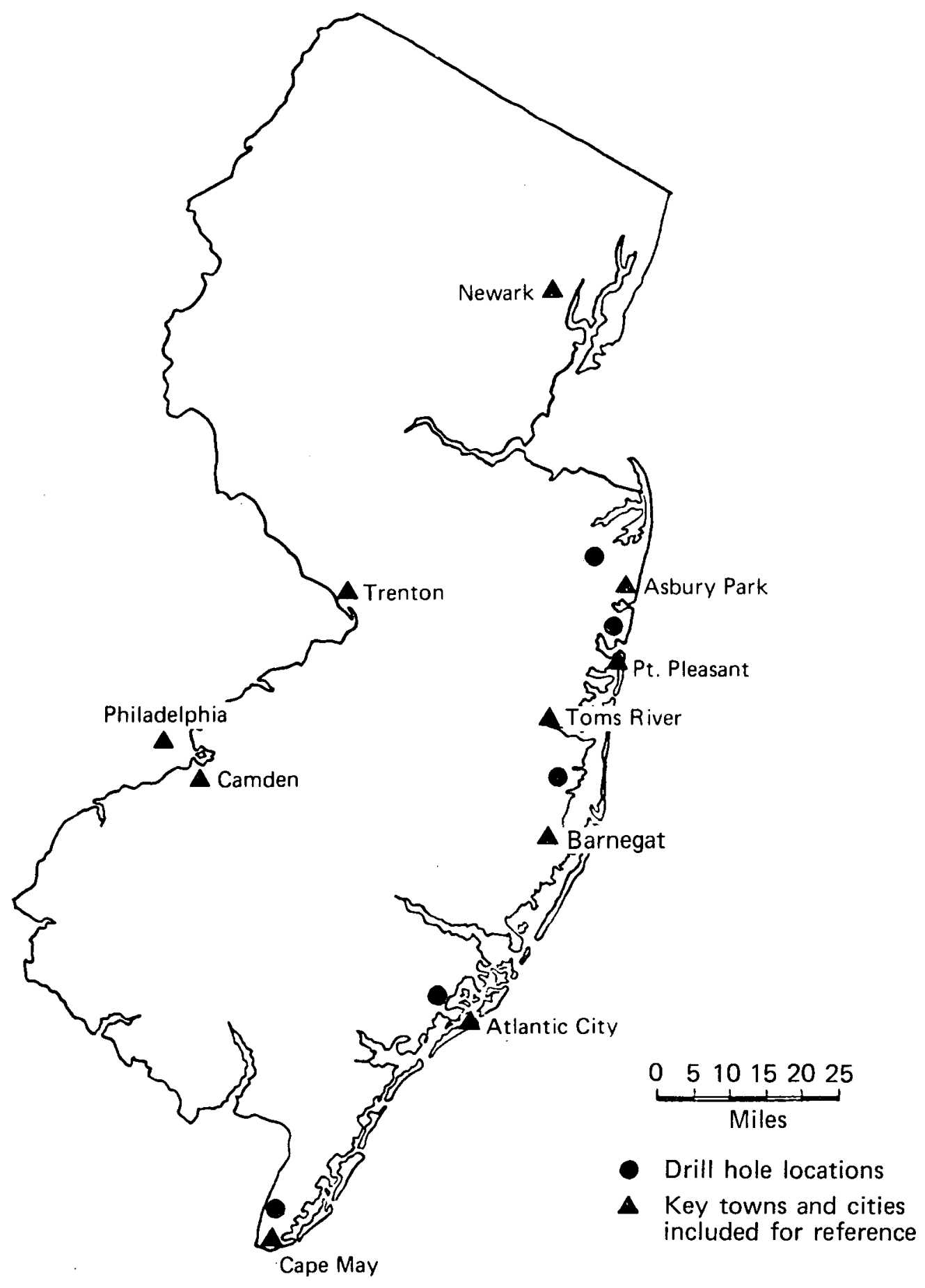

Locations of gradient test holes - New Jersey. 
ENERGY RESOURCES - 1973
ANNUAL PROOUCTION

\begin{tabular}{|c|c|c|c|}
\hline \\
\hline TYPE & SUMBER & starus & $10^{12} \mathrm{Btu}$ \\
\hline Coal Mines & & 9,070 thousand tons & 209.3 \\
\hline Natural Gas (11q.) & & 39,500 thousand bb1 & 159.3 \\
\hline Natural Gas wel1s & 9,711 & $1,218,749$ mil11ion cu. ft. & $1,332.1$ \\
\hline Crude oil wel1s & $\begin{array}{ll}17,099 \\
\end{array}$ & 100,996 thousand $\mathrm{bb}$. & 585.7 \\
\hline
\end{tabular}

ENERGY USE - 1975 10" BTUI

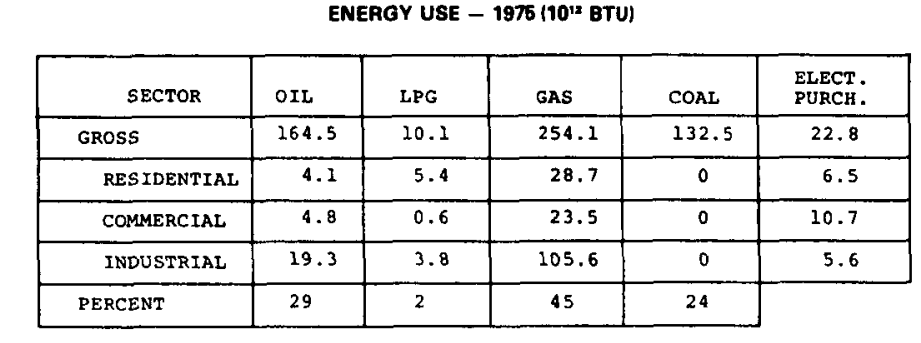

GEOTHERMAL ACTIVITIES

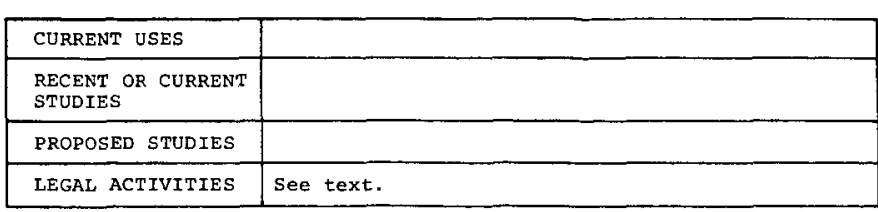

GEOTHERMAL DATA SUMMARY SHEET

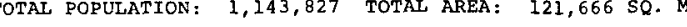

9.4 PERSONS/SS. MI.

GEOTHERMAL OVERVIEW

The Valles Caldera, west of Los Alamos, has been under ral years. Geothermal resources and a $50 \mathrm{MW}$ plant is schedulued to be on line in 1982 . Current exploration is expected to o locate other high temBasin and Range Province in the southwest corner of Ner Mexico. Many low and moderate temperature resources

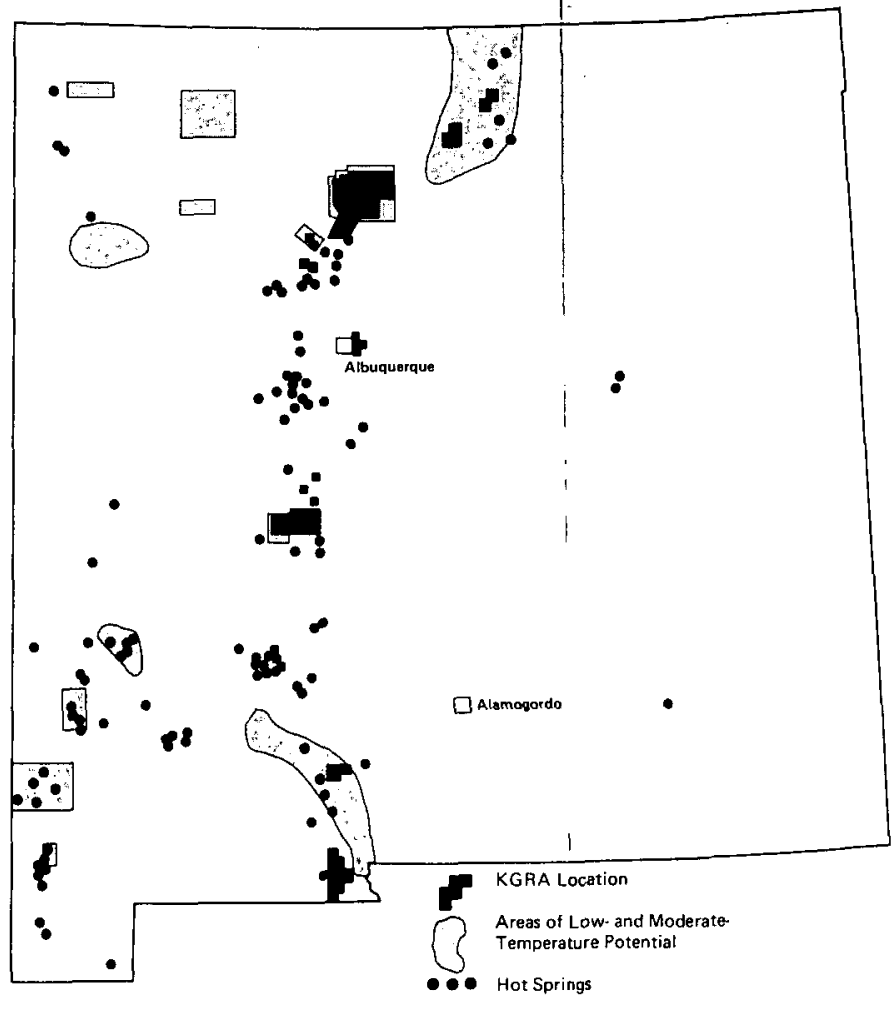

... Hot Springs

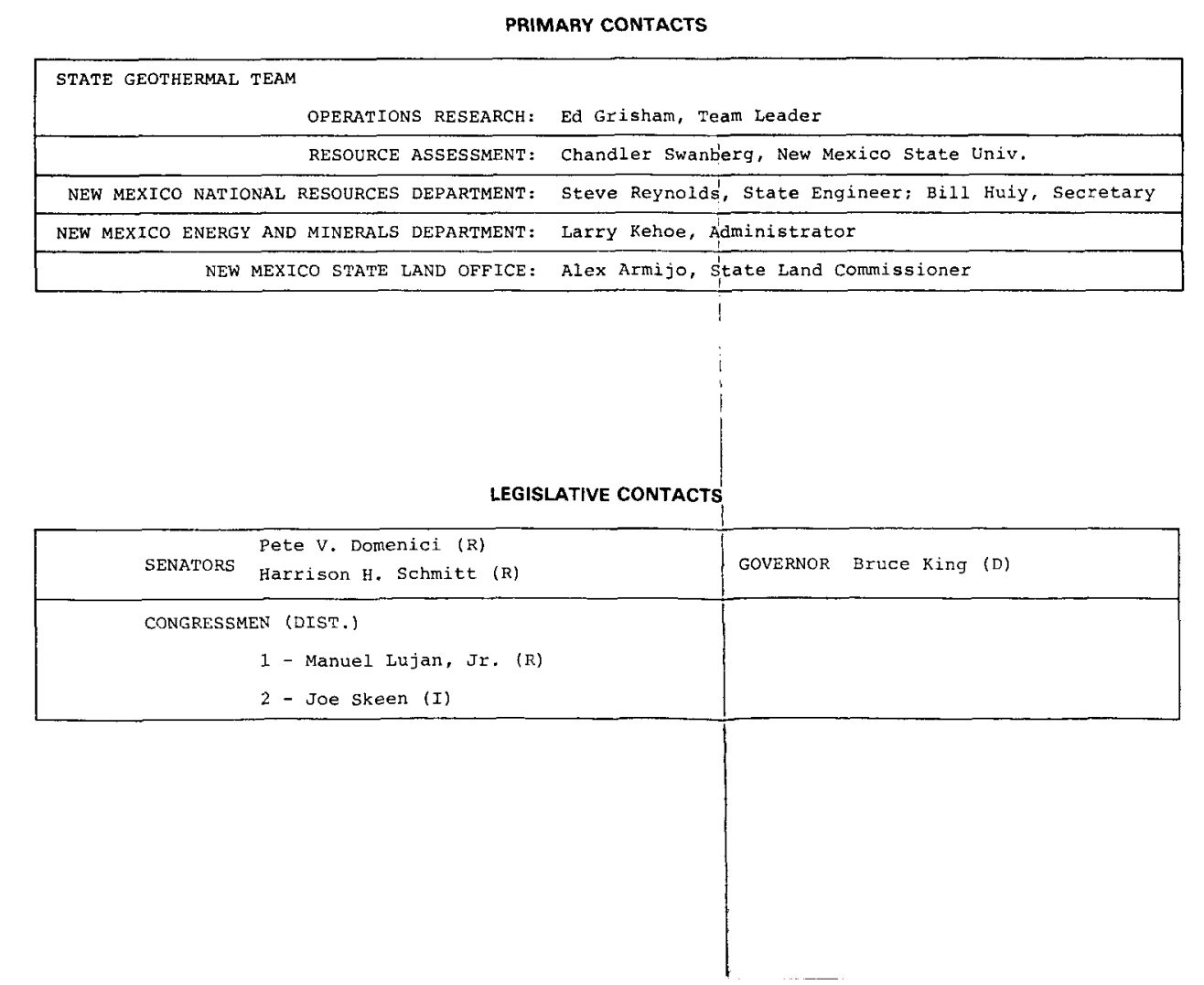



III. STATE FUEL PRODUCTION (1973) (C-6)

Type Number Units $\quad$ Btu

Coal mines

Natural gas (liq.)

Natural gas wells

Crude oil wells

$\begin{array}{rr}6 & 9,070 \text { thousand tons } \\ - & 39,500 \text { thousand bbl } \\ 9,711 & 1,218,749 \text { million cu. ft. } \\ 17,099 & 100,986 \text { thousand bbl }\end{array}$

209.3

159.3

$1,332.1$

585.7

IV. GEOLOGY

Several hundred thermal springs and wells are found in New Mexico. These are concentrated in the Rio Grande Rift and the Basin and Range Province in the southwestern part of the state. Both areas exhibit characteristics associated with geothermal potential: active extensional tectonics, recent volcanism, active seismicity, high heat flow, and young hydrothermal mineral deposits in addition to the springs and wells.

The Rio Grande Rift extends from Colorado through southern New Mexico. The rift zone is composed of a series of en-echelon north-trending grabens and half-grabens. This rift borders, crosses, or merges with the four geologic provinces recognized in Nex Mexico. It passes through the Southern Rocky Mountains and partially adjoins the Colorado Plateau to the west. The Great Plains Province lies to the east of the rift and the Basin and Range abuts the rift to the west. Fault scarps with varying degrees of exposure are common along the length of the rift.

The Rio Grande Rift and adjacent regions have experienced volcanic activity through most of the Cenozoic era. Volcanism concurrent with rifting began about 20 to 26 million years ago, predominantly along the middle and western parts of the rift. Subsequent volcanic activity forms the Jemez Mountains, the Socorro and Magdalena Peaks. The youngest volcanic rocks in the state are about 10 thousand years old.

The hot spring activity in New Mexico corresponds, generally, to the regions of young volcanism and high heat flows $(>2.5$ HFU). These high flows coincide with the entire western part of the Rio Grande Rift, define an area in the vicinity of the Mccarty's basalt and encompass a region in southwestern New Mexico and southeastern Arizona. A portion of the ribbon of high heat flow overlies an area near Socorro where an extensive (>660 sq. mi.) silllike magma body is located a depth of about 11 miles. In southwestern New Mexico the thermal anomaly is associated with the north-trending Basin and Range structures. In this region Quaternary basaltic volcanism is widespread in addition to older silicic volcanic rocks. 


\section{RESOURCE DATA}

Eight KGRAs, totaling about $500 \mathrm{sq}$. mi., have been designated by USGS. One of these, in Valles Caldera, has been confirmed as a high temperature resource. At least four others plus additional areas are considered to be potential high temperature resources. Many prospective low and moderate resources have yet to be confirmed.

\section{GEOTHERMAL ACTIVITIES}

In the Valles Caldera region (the Base Location No. 1 KGRA), Union oil Company has drilled six producing wells with bottom hole temperatures ranging between 460 and $570^{\circ} \mathrm{F}$. This confirmed reservoir is estimated to contain $3 / 4$ cubic mile of water in its 32 cubic mile volume. Electrical potential is rated conservatively as $400 \mathrm{MW}$ for 30 years. A joint venture of Union and the Public Service Co. of New Mexico, with 50\% DOE funding, is to have a 50 MW demonstration plant on line in 1982.

Leases totalling 260,000 acres have been granted (1978), about $75 \%$ on Federal lands, $25 \%$ on state.

The Los Alamos Scientific Laboratory, under DOE sponsorship, has been performing hot dry rock experiments in New Mexico; the 1979 project was a $9 \mathrm{MW}$ extraction loop.

State assisted geothermal heating demonstration projects include a center for the elderly, a hospital, and a greenhouse.

\section{LEGAL ACTIVITIES}

In 1967 the state's Geothermal Resources Act was enacted and required all state lands to be leased through competitive bidding only and for terms of five years. 1973 legislation directed the oil Conservation Division to regulate drilling, development, and production of geothermal resources and to conserve the resources in the same manner as the Division regulated natural gas. This action was followed in 1975 by enactment of the Geothermal Resources Conservation Act and gives the state access to drilling and abandonment records. Also enacted in 1975 was the Energy Research and Development Act, which created a fund to share costs of research and development projects. 1979 legislation clarified procedures and powers in the conservation act and authorized a review of geothermal leasing policies. Various relaxations of leasing policy were recommended for adaption at subsequent meetings of the legislature. 
VIII. CONTACTS

1. State Geothermal Team:

a. Operations Research, Ed Grisham, Team Leader;

b. Resource Assessment, Chandler Swanberg, New Mexico State University.

2. New Mexico National Resources Department, Steve Reynolds, State Engineer; Bill Huiy, Secretary.

3. New Mexico Energy and Minerals Deppartment, Larry Kehoe, Administrator.

4. New Mexico State Land Office, Alex Armijo, State Land Commissioner.

REFERENCES AND LIST OF SIGNIFICANT REPORTS

(1) "New Mexico Hydrothermal Commercialization Baseline," EG\&G Idaho, Inc., May 1979 .

COMMON REFERENCES

$(C-4),(C-6)$, and $(C-7)$. 
GEOTHERMAL DATA SUMMARY SHEET

ENERGY RESOURCES - 1973
ANNUAL PROOUCTION

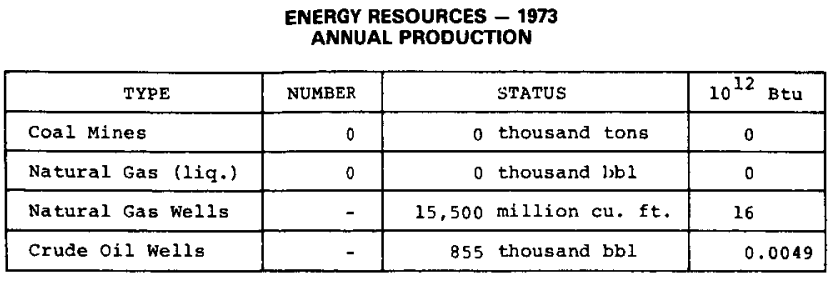

ENERGY USE - 1975 101" BTU

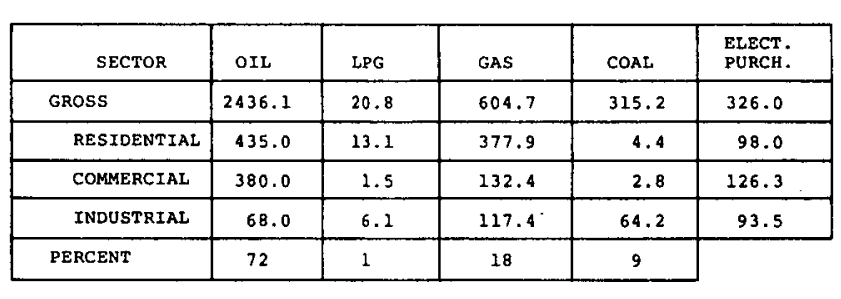

OEOTHERMAL ACTVVTIIES

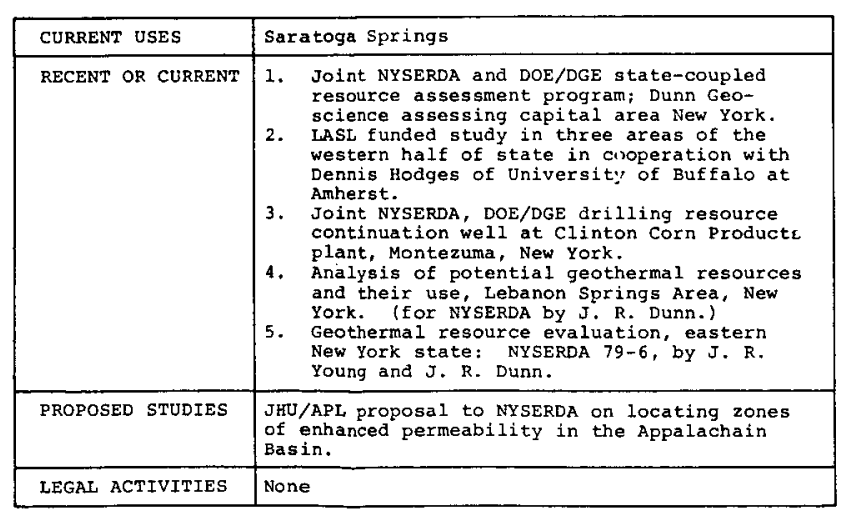

TOORA POOVUATTON: 18, 241,584 TOTAL AREA: 47, 831 SO. MI.

GEOTHERMAL OVERVIEW

Within New York, the Champlain Valley and the Appalachia thermal gradients locally and may have potential as hydrthinner sedimentary cover but higher gradients and may be
attractive for hot dry rock developonent.

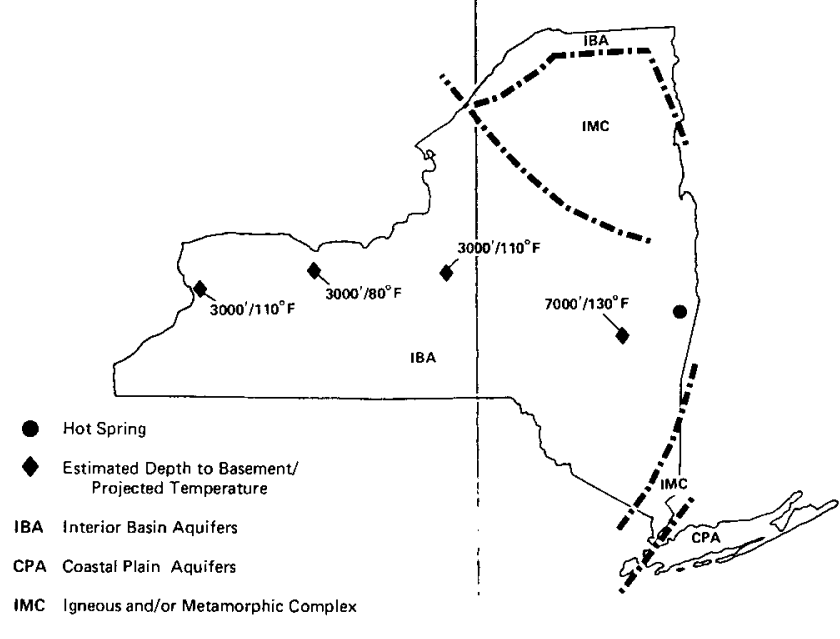

PRIMARY CONTACTS

\begin{tabular}{|c|c|}
\hline \multicolumn{2}{|c|}{ 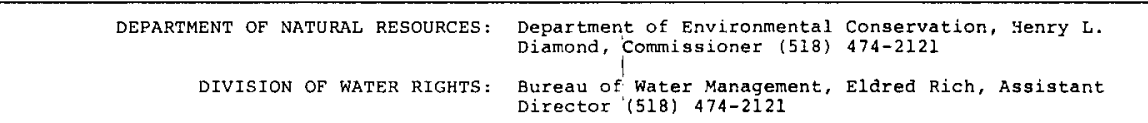 } \\
\hline DEPARTMENT OF ENVIRONMENTAL PROTECTION: & Benry I. Dianond, Comn1ssioner (518) 474-2121 \\
\hline OFFICE OF ENERGY POLICY: & New York $\mid$ state Energy Office, Ted Deboex \\
\hline PLANNING BUREAU: & 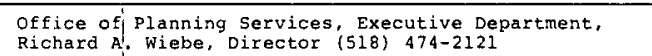 \\
\hline GEOLOGTCAL SURVEY: & Dr. Robert Fakunding, State Geologist (518) 474-5816 \\
\hline & New York ERDA, Dr. Burton Krakow \\
\hline \multicolumn{2}{|c|}{ LEGISLATIVE CÓNTACTS } \\
\hline \begin{tabular}{|l|l} 
SENATORS & $\begin{array}{l}\text { Jacob K. Javitts (R) } \\
\text { Danie1 P. Moynihan (D) }\end{array}$
\end{tabular} & COVERNOR Hugh L. Carey (D) \\
\hline \begin{tabular}{|l|} 
CONGRESSMEN (DIST.) \\
$3-$ Greq Carman (R)
\end{tabular} & Counties: $((P)=$ part $)$ \\
\hline $\begin{array}{l}5 \text { - Raymond } J \cdot \text { MCGrath (R) } \\
6 \text { - John Leboutillier (R) }\end{array}$ & \\
\hline $\begin{array}{l}16-\text { Char 1es E. Schumer (D) } \\
17-\text { Guy V. Molinari (R) }\end{array}$ & \\
\hline $\begin{array}{l}29 \text { - Gerald soloman (R) } \\
30 \text { - David Martin (R) }\end{array}$ & $\begin{array}{l}\text { Renssel aer, Saratoga } \\
\text { oswego (P) } \\
\end{array}$ \\
\hline $\begin{array}{l}32 \text { - George Wortley }(\mathbb{R}) \\
33 \text { - Gary the }(\mathrm{R})\end{array}$ & 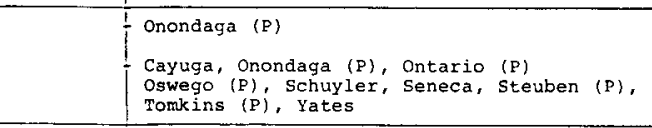 \\
\hline $\begin{array}{l}34-\text { Prank Horton (R) } \\
35 \text { - Barbex B. Conabie, Jr. (R) }\end{array}$ & 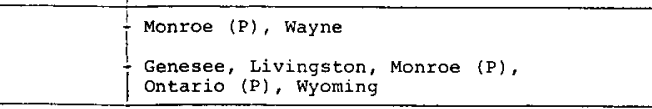 \\
\hline $\begin{array}{l}36 \text { - John J. Lafalce }(D) \\
37 \text { - Henry J. Nowak (D-tib) }\end{array}$ & $\begin{array}{l}\text { Eric (P), Monroe }(\mathrm{P}) \text {, Niagara, orleans } \\
\text { - Brie (P) }\end{array}$ \\
\hline $\begin{array}{l}38-\text { Jack Kemp (R) } \\
39-\text { Stanley N. Eundine (D) }\end{array}$ & 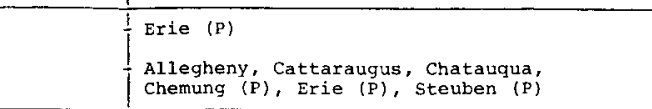 \\
\hline
\end{tabular}


State Geothermal Fact sheet

NEW YORK

I. DEMOGRAPHIC INFORMATION (1970) (C-4)

TOTAL STATE

Population: 18,241,584 Area: $47,831 \mathrm{sq} \cdot \mathrm{mi}$. Density: 381 per sq. mi.

GEOTHERMAL RESOURCE AREA

Population: 2,611,000 Area: 12,672 sq. mi. Density: 206 per sq. mi.

II. ENERGY CONSUMPTION* (1975) (C-7)

$\begin{array}{ccccc}\text { OIL } & \text { LPG } & \text { GAS } & \text { COAL } & \text { ELECTRICITY } \\ \text { (million } & \text { (million } & \text { (trillion } & \text { (million } & \text { PURCHASED } \\ \text { bbl) } & \text { gal.) } & \text { cu.ft.) } & \text { tons) } & \text { (billion kWh) }\end{array}$

GROSS

Residential

Commerical

Industrial

422
75
62
11

11

218
137
15
64

586

327

128

114

Trillion Btu

$\begin{array}{cr}\text { GROSS } & 2436.1 \\ \text { Residential } & 435.0 \\ \text { Commercial } & 380.0 \\ \text { Industrial } & 68.0\end{array}$

Percentages

$\begin{array}{rr}20.8 & 604.7 \\ 13.1 & 377.9 \\ 1.5 & 132.4 \\ 6.1 & 117.4\end{array}$

1
12
0.2
0.1
2

$$
\begin{array}{r}
315.2 \\
4.4 \\
2.8 \\
64.2
\end{array}
$$

96

29

37

27

9

*Excluding nuclear and hydro electricity, coking coal and petroleum coke, and other petroleum products not used as fuels. 
III STATE FUEL PRODUCTION (1979)

$(C-6)$

Type

Coal mines

Natural gas (liq.)

Natural gas wells

crude oil wells
Number

0

0

$-$

$-$
Units

0 thousand tons

0 thousand bbl

15,500 million cu. ft.

855 thousand bbl
Trillion

Btu

0
0
16
0.0049

IV.

\section{GEOLOGY}

Paleozoic sedimentary rocks on the northern limb of the Appalachian Basin underlie most of New York State. These rocks form a wedge that begins on the flanks of the Adirondack Dome and the Frontenac Axis to the north and thickens to more than 10,000 ft. along the New York-Pennsylvania border. The Adirondack Dome consists of Precambrian (Grenville age is about 1.1 billion years ago) rocks, similar in age to the belt of gneisses called the Hudson Highlands that crosses the southeastern part of the state and forms the eastern boundary to the Appalachian Basin. Southeast of this belt lies the Manhattan Prong, a series of late Precambrian to Paleozoic metamorphic rocks. Downdropped between the Manhattan Prong and the Hudson Highlands is the Newark Basin, which is filled with more than 10,000 ft. of Triassic-Jurassic aged sedimentary and igneous rocks. Long Island is underlain by the unconsolidated sediments of the coastal Plain that thicken to about 2000 ft. toward the east.

Several areas of New York state may have geothermal potential. High thermal gradients exist in the Appalachian Basin and are associated with varying amounts of sedimentary cover. Where the cover, which may act as insulation, is thin and coincides with an elevated gradient, such as at Buffalo (3000 ft. to basement), the potential for hot dry rock development is good. The thick sedimentary sequences of the Appalachian, Champlain, and Newark Basins, where they are associated with elevated gradients, may also be exploitable. If these sedimentary sequences contain extractable water at depth, they may contain hydrothermal systems.

V.

RESOURCE DATA

High gradients $(>2.0 \% / 100 \mathrm{ft.})$ have been measured in the western part of the state between Binghamton and Buffalo and Syracuse. In this area the sedimentary rocks thicken from $2000 \mathrm{ft}$. in the north to an excess of $12,000 \mathrm{ft}$. in the south.

No gradient data are available for the Champlain Valley. However, this basin is genetically, structurally, and magmatically related to the Montreal region, which has the highest gradients 
(greater than $3.0^{\circ} \mathrm{F} / 100 \mathrm{ft.}$ ) recorded in eastern North America. If similar gradients exist in this area, then the temperatures at the base of the 10,000 to $15,000 \mathrm{ft}$. sequence in the Albany area may be significant. The extensive faulting in the champlain Valley may provide the framework for a regional convection system. Differential vertical movements across this 15,000-ft. deep basin are presently occurring. Locally, $\mathrm{CO}_{2}$ is produced from shallow water wells, which may indicate a shallow heat source at the base of the sediment.

No gradient data are available for the northeastern end of the Newark Basin, which lies in southeastern New York. Although this part of the Basin is not known to exceed a depth of $5000 \mathrm{ft}$., its control by major crustal faults make it a likely insulating cap for a potential convection system.

\section{GEOTHERMAL ACTIVITY}

Current studies: 1. New York ERDA together with DOE/DGE has funded Dunn Geoscience Corp. to study $\mathrm{CO}_{2}$ rich waters in the capitol area (Rensselaer Co.) (4). Dunn also studied water-referenced heat pumps on a contract with the National Water Well Association. NYSERDA and Dunn Geoscience are studying space heating of public buildings with heat pumps and water from springs at Lebanon Springs, New York (8).

2. DOE/DGE and NYSERDA are drilling a resource confirmation well near Clinton Corn Products Plant, Montezuma, NY (6) and (9).

3. IASL has funded a study (5) of heat flow and thermal gradients in the western half of the state as a potential HDR demonstration site.

VII. LEGAL ACTIVITIES

To be determined.

VIII. CONTACTS

1. New York ERDA, Agency Building No. 2, Empire State Plaza, Albany, NY 12223, Dr. B. Krakow. 
2. Geologic Survey, New York state Education Building, Albany, NY 12224, Dr. Robert Fakunding, (518) 474-5816.

3. New York State Energy Office, Albany, NY, Ted Deboer.

4. Dunn Geoscience Corp., North Latham, NY 12110, James R. Dunn.

\section{REFERENCES AND LIST OF SIGNIFICANT REPORTS}

(1) Y. W. Isachsen, "Investigations of Two Areas in New York State Which May Have Potential for Geothermal Energy," State University of New York, COO-2694-3.

(2) Y. W. Isachsen, et al., "The Panther Mountain Circular Structure: A Possible Buried Meteorite," Guide Book to Field Excursions - 49th Annual Meeting N.Y. State Geological Association.

(3) Y. M. Isachsen, "Contemporary Doming of the Adirondack Mountains, N.Y.," Trans. American Geophysics Union, EOS Vol. 57, No. 325, 1976.

(4) "Geothermal Resource Evaluation - Eastern New York State," Dunn Geoscience Corp. Report NYSERDA 79-6, Aug 1979.

(5) Geothermal Studies, Western New York, K. G. Hilfiker, State University, N.Y., Buffalo, Published in Common Ref. $(C-8)$.

(6) NYSERDA Proposal, Montezuma (Cayuga County, N.Y.).

(7) "Requirements for Hydrologic Test Well in Western New York State," JHU/APL Letter CQO-2852 to Dr. B. Krakow, NYSERDA, Apr 3, 1980.

(8) "Analysis of Potential Geothermal Resources and Their Use, Lebanon Springs Area, New York," Dunn Geoscience Corp. Draft Report to NYSERDA, $17 \mathrm{JuI} 1980$.

(9) "Geothermal Energy in Cayuga County, New York," JHU/APL QM-80-082, 28 May 1980 .

\section{COMMON REFERENCES}

$(c-4),(c-6),(c-7)$, and $(c-8)$. 


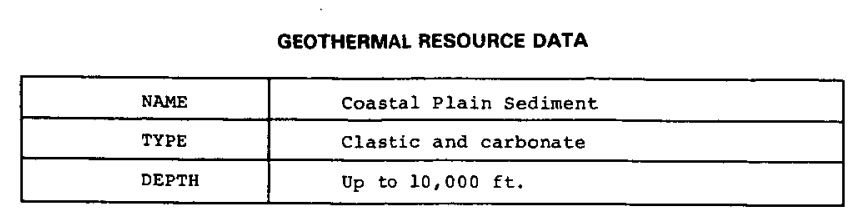

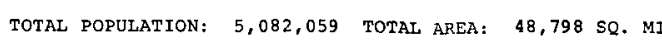

MPULATION DENSITY: 204 PBRSONS/SQ. MI.

GEOTHERMAL OVERVIEW

The thickness of sediments within the Atlantic Coastal locations of high gradient do occur and theretore repre-

ENERGY RESOURCES - 1973
ANNUAL PROOUCTION

\begin{tabular}{|c|c|c|c|}
\hline \multicolumn{4}{|c|}{ 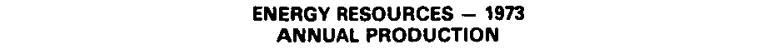 } \\
\hline TYPE & RUMEER & 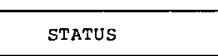 & $10^{12} \mathrm{Btu}$ \\
\hline Coal mines & 0 & 0 thousand tons & 0 \\
\hline Natura1 Gas (11q.) & 0 & 0 thousand bb1 & 0 \\
\hline Natura 1 Gas we11s & 0 & 0 million $\mathrm{eu}$. $\mathrm{ft}$. & 0 \\
\hline Crude ofl we $11 \mathrm{~s}$ & 0 & 0 thousand bb1 & 0 \\
\hline
\end{tabular}

ENERGY USE - 1975 (10' BTU)

\begin{tabular}{|c|c|c|c|c|c|}
\hline SECTOR & OIL & IPG & GAS & $\operatorname{cost}$ & 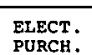 \\
\hline GRoss & 731. & 22.5 & 75.0 & 534.0 & 198.0 \\
\hline RESTIDENTIAT & 69.0 & 10.0 & 33.0 & 2.1 & 76.0 \\
\hline COMUR RC IAL & 32.0 & 1.1 & 19.0 & $\begin{array}{ll}1.6 \\
\end{array}$ & 49.0 \\
\hline INDUSTRIAL & 95.0 & 11.1 & 20.0 & 46.0 & 72.0 \\
\hline PERCENT & so & 2 & 5 & 36 & \\
\hline
\end{tabular}

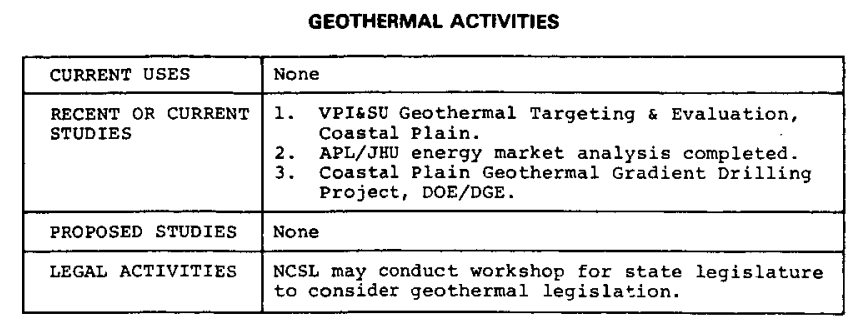

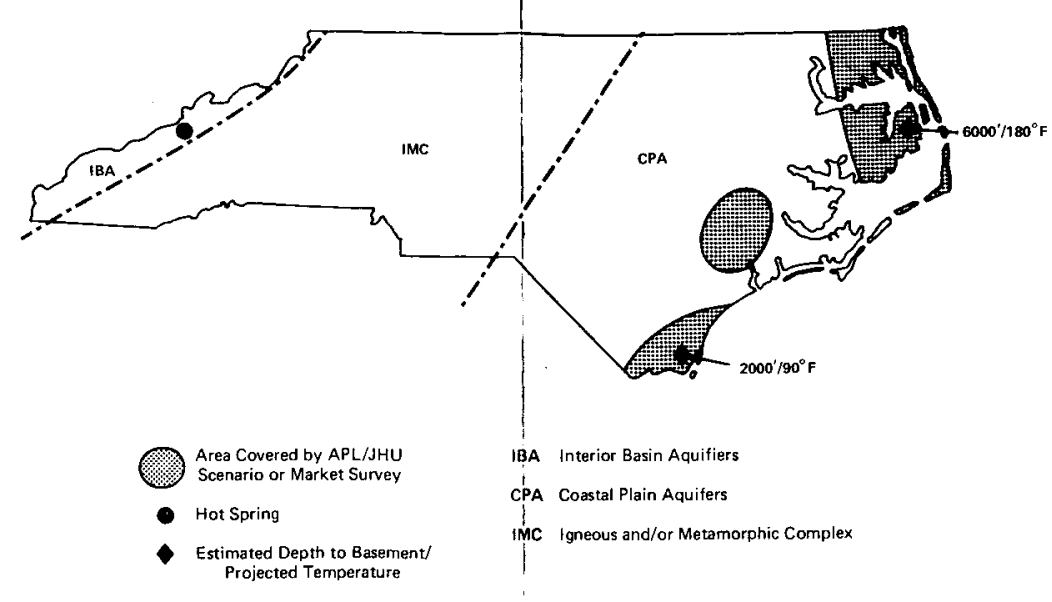

PRIMARY CONTACTS

ENERGY DTVISTON: Brian Plattery, Director (919) 733-2230

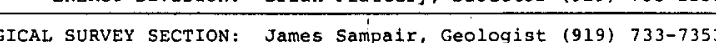
COAST ZONE MANGGBRENT: Ken Stewart (1919) $733-2293$

LAND USE PLANNING: Mark SUL11ivan (919) 733-3833

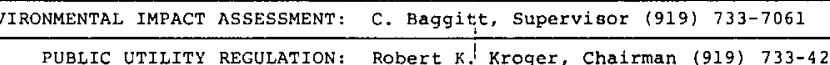
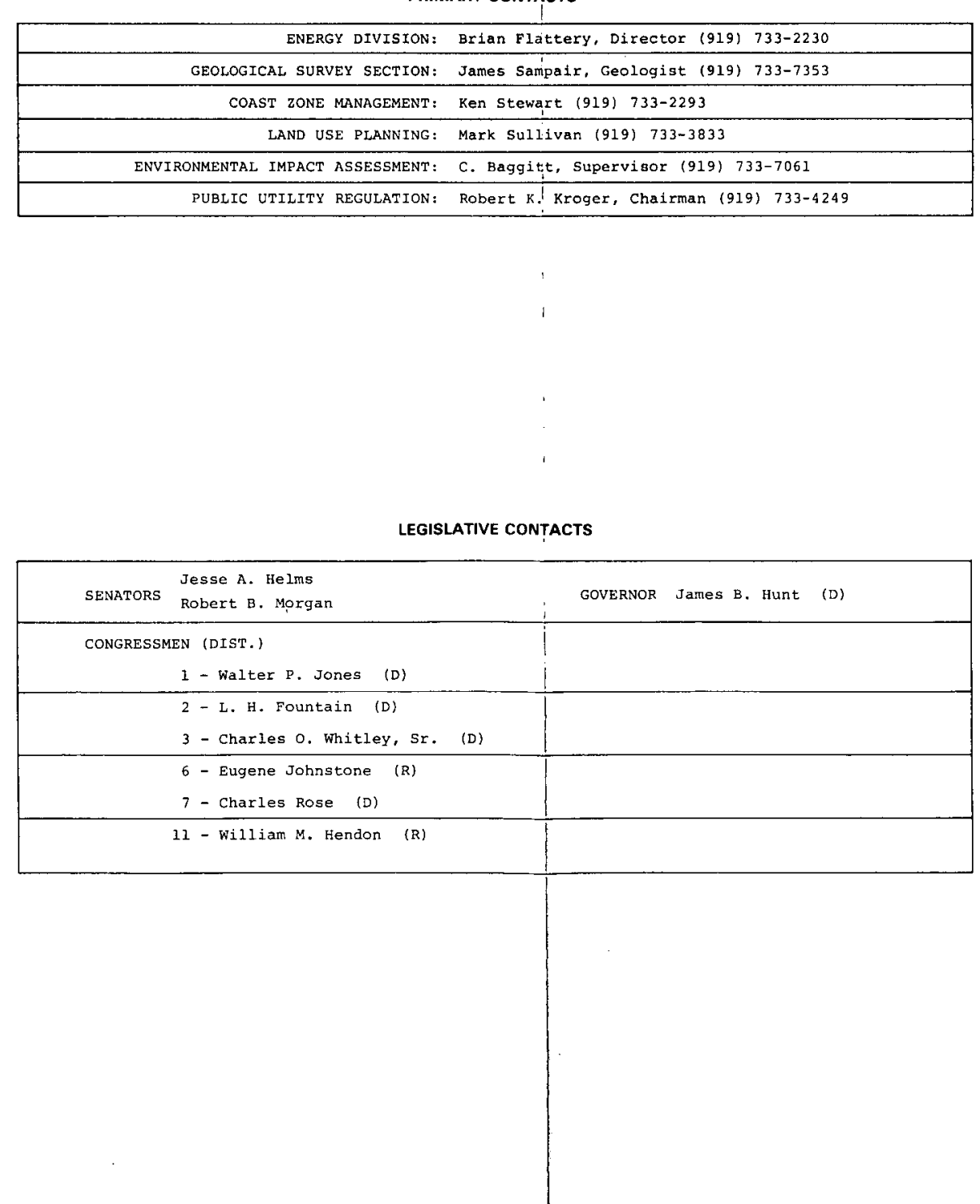

III. STATE FUEL PRODUCTION (1973) (C-6)

Type Number

Coal mines

Natural gas (1iq.)

Natural gas wells

crude oil wells
Units

0 thousand tons

0 thousand bbl

0 million cu. ft.

0 thousand $\mathrm{bbl}$
Trillion

Btu

\section{0}

0

0

0

IV. GEOLOGY

The surface of the basement complex to the north of Wilmington dips to the southeast attaining a maximum onshore depth of approximately 10,000 ft. in the vicinity of Cape Hatteras. Coastal plain sediments, which range in age from cretaceous to Recent, form a southeasterly thickening wedge that overlies the Precretaceous basement complex. An onshore positive basement structure, trending northwest-southeast, is the dominant structural feature south of Wilmington. This feature, the Cape Fear Arch, is covered by a thin (about $1500 \mathrm{ft.}$ ) veneer of sedimentary rocks.

V. RESOURCE DATA

The DOE/DGE sponsored geothermal drilling program drilled eleven $1000 \mathrm{ft}$. gradient holes in the North Carolina coastal plain. The geothermal gradients varied from $22^{\circ} \mathrm{C} / \mathrm{km}$ to $41^{\circ} \mathrm{C} / \mathrm{km}\left(1.2^{\circ} \mathrm{F} /\right.$ $100 \mathrm{ft}$. to $\left.2.2^{\circ} \mathrm{F} / 100 \mathrm{ft}.\right)$. Since the depth to basement is 2000 to $3000 \mathrm{ft}$. over much of the coastal plain, estimates of temperatures at basement are modest, i.e., $30^{\circ} \mathrm{C}$ to $44^{\circ} \mathrm{C}$ (86 to $112^{\circ} \mathrm{F}$ ). However for several holes on the mainland, to the west of cape Hatteras, and where the depth to basement is 4000 to $5000 \mathrm{ft}$., temperatures at basement are estimated to be as high as $85^{\circ} \mathrm{C}$ $\left(185^{\circ} \mathrm{F}\right)(3)$.

VI. GEOTHERMAL ACTIVIES

The geothermal gradient test holes sponsored by the DOE/DGE drilling program have been completed and the results have been assessed by VPI\&SU. API/JHU has conducted and published a study of the energy markets in the northern coastal region of the state (6). APL has forwarded information to a utility (Carolina Power and Light) on the nature and prospects for geothermal energy.

VII. LEGAL ACTIVITIES

NCSI may conduct a workshop for state legislature to consider geothermal legislation. 
VIII. CONTACTS

1. Energy Division, 430 N. Salisbury St., Raleigh, NC 27611, Brian Flattery, Director, (919) 733-2230.

2. Energy Policy Council, c/o Energy Division, $430 \mathrm{~N}$. Salisbury St., Raleigh, NC 2761l, (15 member council), (919) 733-2230.

3. Energy Facility Siting, N.C. Utilities Commission, Public Staff, 430 N. Salisbury St., Raleigh, NC 27611, Andrew W. Williams, Chief, Electric Division, (919) $733-2267$.

4. Public Utility Regulation, N.C. Utilities Commission, 430 N. Salisbury St., Raleigh, NC 27611, Robert K. Koger, Chairman, (919) 733-4249.

5. Legislative Energy Related Committees, Legislative Building, Raleigh, NC 27603, (919) 733-7044.

a. Public Utilities and Energy Committee State House of Representatives Representative Dwight $W$. Quinn, Chairman Terrence Sullivan, Director of Research

b. Public Utilities and Energy Committee State Senate Senator James B. Garrison, Chairman Terrence Sullivan, Director of Research

6. Legislative Services, Legislative Services Office, Legislative Building, Raleigh, NC 27603, John Allen, Legislative Services officer, (919) 733-7044.

7. Resource Planning and Inventory Section, Division of Land Resources, Dept. of Natural Resources \& Community Development, P.O. Box 27687, Raleigh, NC 27611, Mark Sullivan, Chief, (919) 733-3833.

8. Geological Survey Section, Division of Land Resources, Dept. of Natural Resources \& Community Development, P.O. Box 27687, Raleigh, NC 27611, James Sampair, Senior Geologist for the Coastal Plain, (919) 733-7353.

9. Coastal Zone Management, Dept. of Natural Resources and Community Development, P.O. Box 27687, Raleigh, NC 2761l, David Owens, Chief of Planning and Technical Services, (919) 733-2293. 
10. Environmental Impact Assessments, Division of Budget Management, $116 \mathrm{w}$. Jones St., Raleigh, NC 27603, Crys Baggett, Clearinghouse Supervisor, (919) 733-7061.

11. State Coupled Reservoir Assessment Program, VPI\&SU, Blacksburg, VA 24061, Prof. John Costain, Geothermal Program, (703) 961-5096.

REFERENCES AND LIST OF SIGNIFICANT REPORTS

(1) P. M. Brown, J. A. Miller, and F. M. Swain, "Structural and Stratigraphic Framework and Spatial Distribution of Permeability of the Atlantic Coastal Plain, North Carolina to New York," U.S.G.S. Professional Paper 796, 1972 .

(2) "Evaluation and Targeting of Geothermal Energy Resources in the Southeastern United States, Progress Report oct 1, 1978 - March 30, 1979," VPI\&SU, Blacksburg, VA, DOE Report VPI-SU-5648-5.

(3) "Geothermal Resources of the Eastern United States," Gruy Federal, Inc., Arlington, VA, DOE Report DOE/ET/ $28373-\mathrm{T} 2$.

(4) "Geothermal Energy Market Study in the Atlantic Coastal Plain, Definitions of Markets for Geothermal Energy in the Northern Atlantic Coastal Plain," APL/JHU GEM-002 (QM-80-075), May 1980 .

\section{COMMON REFERENCES}

$$
(C-1),(C-4),(C-5),(C-6), \text { and }(C-7) \text {. }
$$




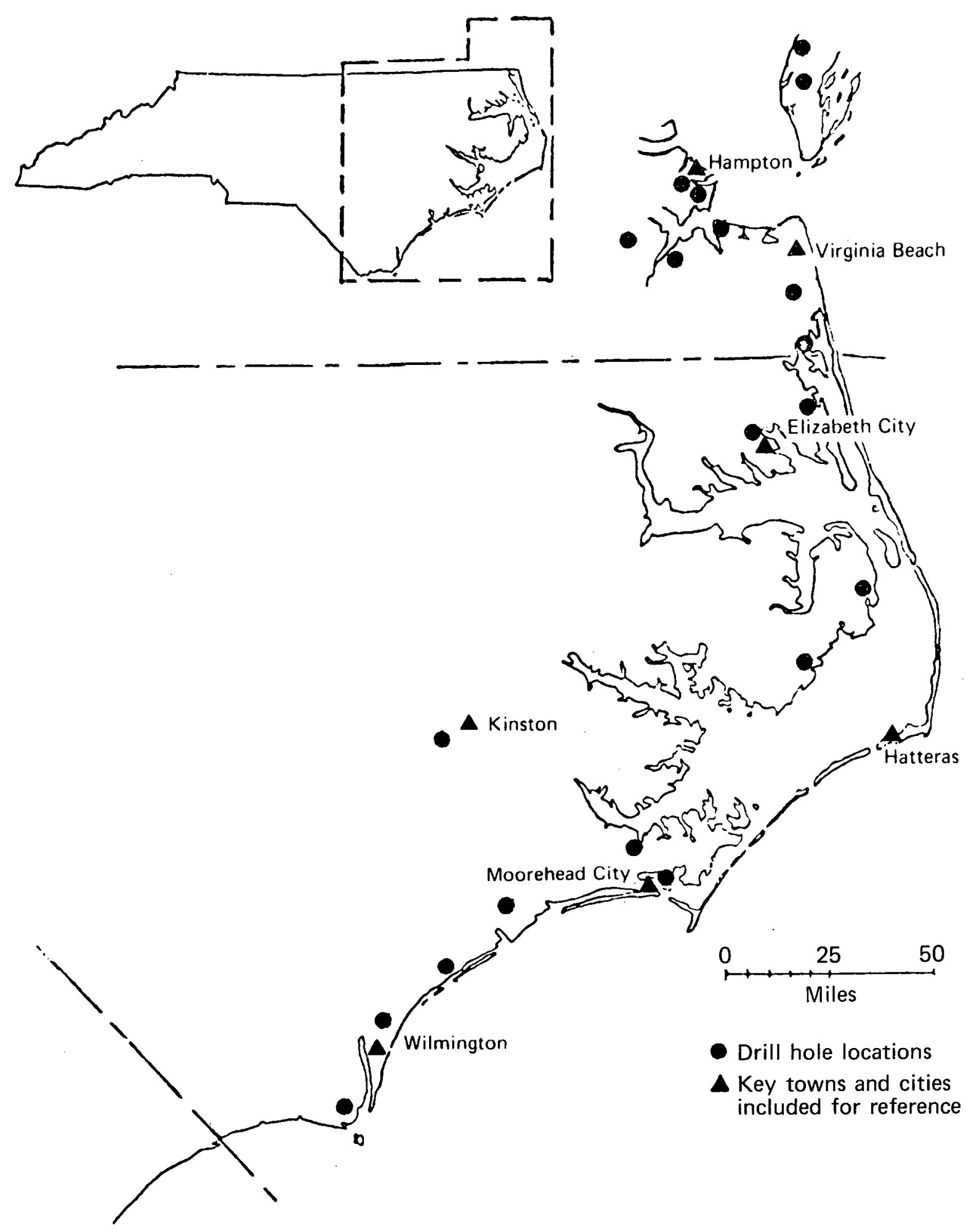

Locations of gradient test holes - Eastern North Carolina. 
ENERGY RESOURCES - 1975
ANNUAL PRODUCTION

\begin{tabular}{|c|c|c|c|}
\hline TYPE & NUMBER & STARus & $10^{12} \mathrm{stu}$ \\
\hline Coal mines & 12 & 6,905 thousand tons & 97.8 \\
\hline Natural Gas (1iq.) & & 1,889 thousand $1, b 1$ & 7.6 \\
\hline Natural Gas we11s & 44 & 27,703 mil11ion cu. ft. & 30.3 \\
\hline Crude oil wells & 1,404 & 20,235 thousand bb1 & 117.4 \\
\hline
\end{tabular}

POPULATION: 617,761 TOTAL AREA: 70,665 SO-$$
\text { POEUIATTON DENSTTY: } 8.7 \text { PERSONS/SQ. M }
$$

GEOTHERMAL OVERVIEW

Western North Dakota is underlain by the Madison aquifer and thus is thought to have some geothermal potentid. However the present knowledge of the extent, quality, an
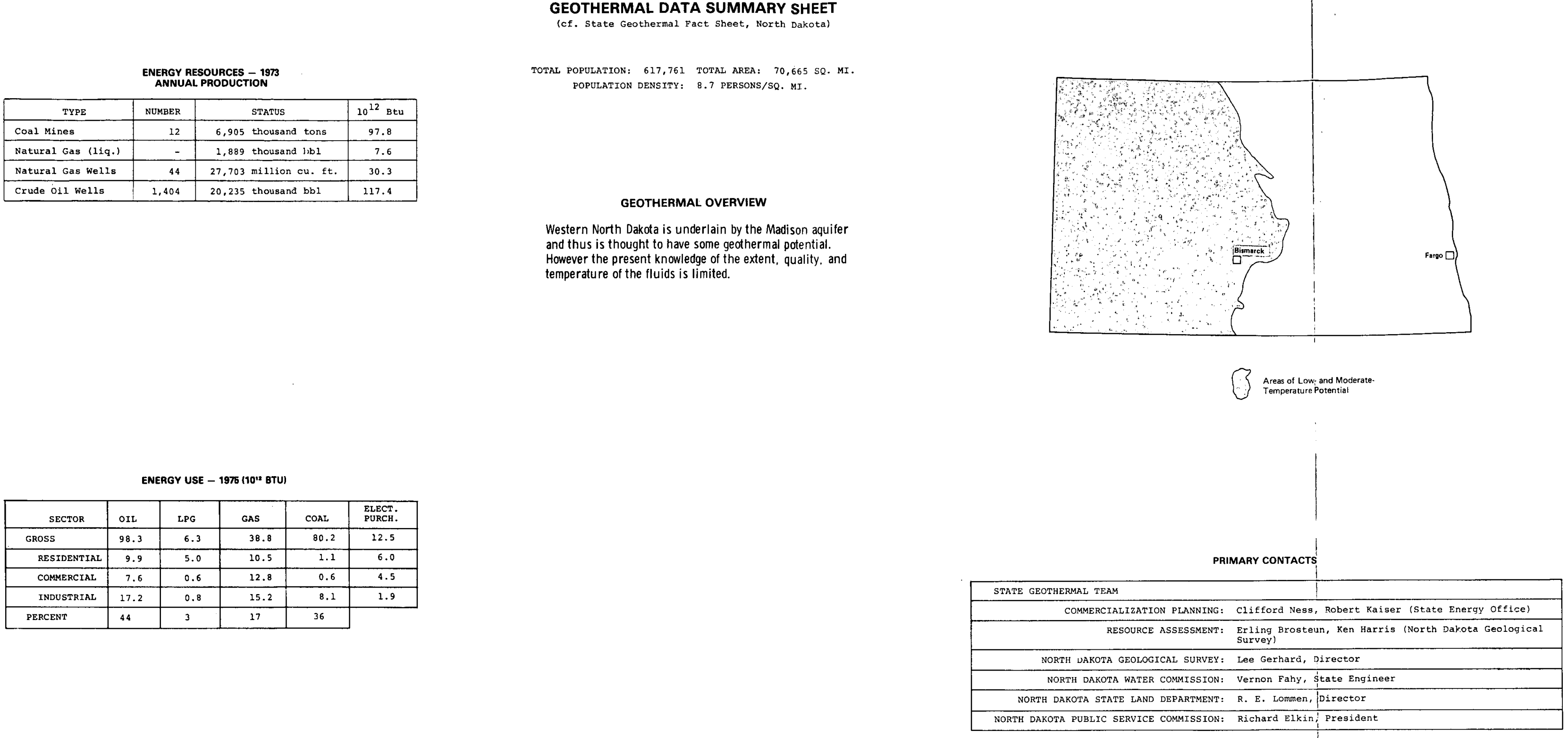

GEOTHERMAL ACTVITIES

\begin{tabular}{|c|c|}
\hline \multicolumn{2}{|l|}{$\begin{array}{l}\text { CURRENT USES } \\
\end{array}$} \\
\hline $\begin{array}{l}\text { RECENT of CURRENI } \\
\text { STYNIISS }\end{array}$ & \\
\hline PROPOSED STUDIES & \\
\hline LEGAL ACTIVITIES & \\
\hline
\end{tabular}

LEGISLATIVE CONTACTS

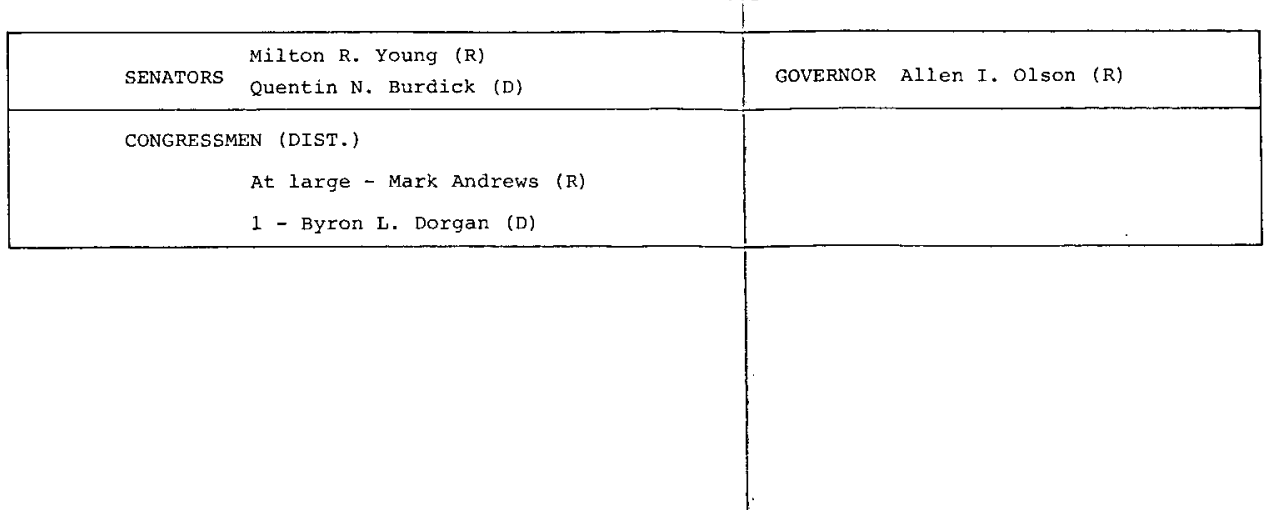



III. STATE FUEL PRODUCTION (1973) (C-6)

Type Number

Coal mines

Natural gas (1iq.)

Natural gas wells

Crude oil wells
12
-
44
1,404

6,905 thousand tons

1,889 thousand bbl

27,703 milition cu. ft. 20,235 thousand bbl

Trillion

Btu

97.8
7.6
30.3
117.4

\section{GEOLOGY}

North Dakota lies entirely in the Great Plains physiographic province. The geologic feature of interest with respect to geothermal energy is the Madison aquifer occuring in the western half of the state. The Madison contains a regionally connected system of fracture-and-solution-opening porosity with principal recharge at outcrops on the periphery of the Black Hills in South Dakota. These recharge waters flow outward and downward below the surface. In the Williston Basin region, the Madison is 10,000 ft. deep, and waters are estimated to be as hot as $230^{\circ} \mathrm{F}$. Water quality ranges from good to poor due to the occurrence of evaporite beds in the upper part of the Madison. Current understanding of the extent and temperatures of waters in the Madison or other potential aquifers is very limited.

V.

\section{RESOURCE DATA}

There are no designated KGRAs in North Dakota and there are no confirmed reservoirs. The Madison aquifer, however, must be classed as an excellent prospect for low and medium temperature applications.

VI. GEOTHERMAL ACTIVITY

The only known operational geothermal system heats and air conditions a farm house and barn in south-central North Dakota.

No leasing of federal or state lands has been done. Some measurements of gradient and heat flow have been made at existing gas and oil wells and uranium test holes.

Several Area Development Plans are being prepared as part of the DOE commercialization effort.

VII. LEGAL ACTIVITIES

No state legislation has been developed to establish policies concerning geothermal exploration or utilization. 
VIII. CONTACTS

1. State Geothermal Team:

a. Commercialization Planning: Clifford Ness, Robert Kaiser (State Energy Office);

b. Resource Assessment: Erling Brosteun, Ken Harris (North Dakota Geological Survey).

2. North Dakota Geological Survey, Lee Gerhard, Director.

3. North Dakota Water Commission, Vernon Fahy, State Engineer.

4. North Dakota state Land Department, R. E. Lommen, Director.

5. North Dakota Public Service Commission, Richard Elkin, President.

REFERENCES AND LIST OF SIGNIFICANT REPORTS

(1) "North Dakota Hydrothermal Commercialization Baseline," EG\&G Idaho, Inc., Aug 1979.

COMMON REFERENCES

$(C-4),(c-6)$, and $(C-7)$. 
State Geothermal Fact sheet

OHIO

I. DEMOGRAPHIC INFORMATION (1970) (C-4)

TOTAL STATE

Population: $10,651,848$ Area: 40,975 sq. mi. Density: 260 per sq. mi.

GEOTHERMAL RESOURCE AREA

Population:

Area: sq. mi. Density: per sq. mi.

II. ENERGY CONSUMPTION* (1975) (C-7)

\begin{tabular}{|c|c|c|c|c|c|}
\hline & $\begin{array}{l}\text { OIL } \\
\text { (million } \\
\text { bbl) }\end{array}$ & $\begin{array}{l}\text { LPG } \\
\text { (million } \\
\text { gal.) }\end{array}$ & $\begin{array}{c}\text { GAS } \\
(\text { trillion } \\
\text { cu.ft.) }\end{array}$ & $\begin{array}{l}\text { COAL } \\
\text { (million } \\
\text { tons) }\end{array}$ & $\begin{array}{l}\text { ELECTRICITY } \\
\text { PURCHASED } \\
\text { (billion kWh) }\end{array}$ \\
\hline $\begin{array}{l}\text { GROSS } \\
\text { Residential } \\
\text { Commerical } \\
\text { Industrial }\end{array}$ & $\begin{array}{r}182 \\
14 \\
9 \\
15\end{array}$ & $\begin{array}{r}313 \\
217 \\
24 \\
69\end{array}$ & $\begin{array}{l}965 \\
428 \\
169 \\
353\end{array}$ & $\begin{array}{l}68 \\
0.5 \\
0.3 \\
8.4\end{array}$ & $\begin{array}{r}105 \\
28 \\
22 \\
54\end{array}$ \\
\hline \multicolumn{6}{|c|}{ Trillion Btu } \\
\hline $\begin{array}{l}\text { GROSS } \\
\text { Residential } \\
\text { Commercial } \\
\text { Industrial }\end{array}$ & $\begin{array}{r}993.4 \\
81.0 \\
53.4 \\
89.0\end{array}$ & $\begin{array}{r}29.8 \\
20.7 \\
2.3 \\
6.6\end{array}$ & $\begin{array}{l}996.1 \\
441.5 \\
174.8 \\
364.2\end{array}$ & $\begin{array}{r}1582.0 \\
13.1 \\
7.1 \\
218.2\end{array}$ & $\begin{array}{r}356.6 \\
95.6 \\
76.4 \\
184.5\end{array}$ \\
\hline Percentages & 28 & 1 & 28 & 44 & \\
\hline
\end{tabular}

*Excluding nuclear and hydro electricity, coking coal and petroleum coke, and other petroleum products not used as fuels. 
III. STATE FUEL PRODUCTION (1973) $(\mathrm{C}-6)$

Type Number Units $\quad$ Btu

Coal mines

Natural gas (liq.)

Natural gas welis

Crude oil wells

\author{
235 \\ $9,40 \overline{6}$ \\ 15,236
}
45,785 thousand tons
0 thousand bbl
93,610 million cu. ft.
8,796 thousand bbl

Trillion Btu

$$
\begin{array}{r}
1,126.3 \\
0 \\
102.3 \\
51.0
\end{array}
$$

IV. GEOLOGY

An eastward thickening, Paleozoic, sedimentary wedge overlies the Precambrian basement complex throughout Ohio. This sequence of rocks belongs to the western limb of the Appalachian Basin and is $1000 \mathrm{ft}$. thick in the west, adjacent to Indiana, but thickens considerably, to $12,000 \mathrm{ft}$, , in the eastern part of the state. The Cincinnati Arch is the north-south basement high that separates the Appalachian Basin from the Illinois Basin. The basement, where intersected by drilling, is composed largely of igneous rock to the west of the arch and of metamorphic rocks to the east.

The Paleozoic sedimentary rocks of the western two thirds of the state are overlain by Pleistocene glacial till. Fresh, shallow ground water is abundant in the till to a depth of $400 \mathrm{ft}$. Ground water becomes brackish at greater depths in the sedimentary sequence. The Mt. Simon sandstone, which is the basal sedimentary unit that underlies most of the state, is used for toxic waste disposal. It apparently contains copious amounts of water; however, the water is of high salinity, i.e., about 100,000 ppm.

V. RESOURCE DATA

Geothermal gradients in the eastern parts of the state commonly exceed $1.5^{\circ} \mathrm{F} / 100 \mathrm{ft}$. In regions where the elevated gradients coincide with the deeper parts of the sedimentary sequence, temperatures may be as high as $200^{\circ} \mathrm{F}$ at 10,000 ft.

VI. GEOTHERMAL ACTIVITY

To be determined.

VII. IEGAL ACTIVITIES

To be determined. 
VIII. CONTACTS

1. Department of Natural Resources, David LaValle, Acting Administrator, (614) 466-6320.

2. Environmental Protection Agency, Ned E. Williams, Director, (614) 466-8318.

3. Energy Emergency Commission, Peter Susey, Chief of Policy Development, (614) 466-8102.

4. Department of Natural Resources, Planning Services, Dave Lavalle, Acting Administrator, (614) 466-6320.

5. Geological Survey, Division Chief and State Geologist, Horace R. Collins, (614) 466-5344.

6. Energy Advisory Council (selected membership), Jack Hope, Chairman; William Maddox, Ohio Dept. of Natural Resources; Robert S. Ryan, Ohio Energy Emergency Commission; Ned Williams, Ohio Environmental Protection Agency; (614) 466-6797.

REFERENCES AND LIST OF SIGNIFICANT REPORTS

(1) "Geothermal Resources of the Eastern United States," Report for DOE, DOE/ET/28373-T2, Gruy Federal, Inc., Arlington, Va.

(2) "Hot Dry Rock Geothermal Energy Development Project, Annual Report Fiscal Year 1977," Los Alamos Scientific Laboratory, LA-7109-PR.

COMMON REFERENCES

$(C-4),(C-6)$, and $(C-7)$. 
ENERGY RESOUACES - 1993
ANNUAL POODUCTION

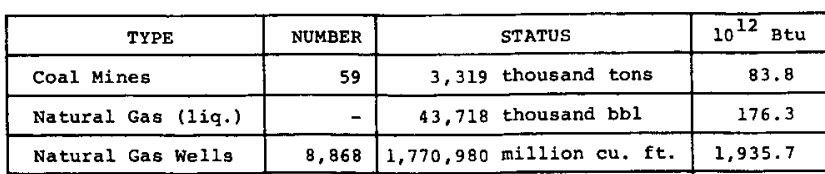

\begin{tabular}{|l|r|r|r|}
\hline Natural Gas we119 & 8,868 & $1,770,980$ million cu. ft. & $1,935.7$ \\
\hline
\end{tabular}

\begin{tabular}{|l|r|l|l|}
\hline Cruade 011 wel1 $1 \mathrm{~s}$ & 72,880 & 191,204 thoussand bb1 & $1,109.0$ \\
\hline
\end{tabular}

ERRQY USE - 1975 100" BTU1

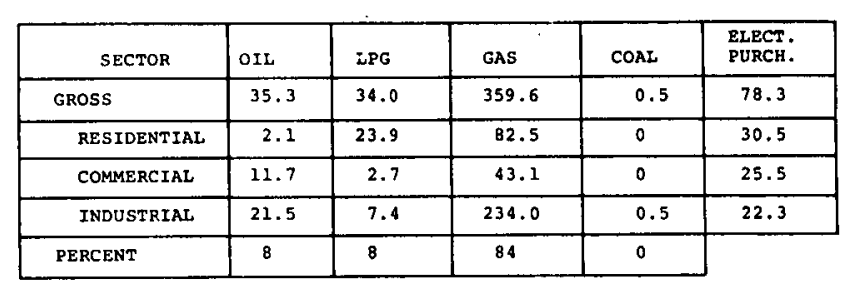

GEOTHERMar Activites

\begin{tabular}{|c|c|}
\hline CURRENT USBS & None \\
\hline $\begin{array}{l}\text { RECENT OR CORRENT } \\
\text { STTOPISS }\end{array}$ & None \\
\hline Propossp STUDTES & Wone \\
\hline
\end{tabular}

OKLAHOMA

GEOTHERMAL DATA SUMMARY SHEET

FOTAM POPULATTON: 2, 559, 229 TOTRA AREA: 68,782 sQ.

\section{GEOTHERMAL OVERVIEW}

A fault bounded basin containing a thick sequence of con-

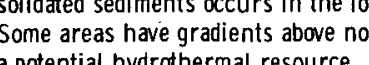
Some areas have gradients above normal and may represent
a potential hydrothermal resource. High water yiels have
been ottained from oil wells.

PRIMARY CONTACTS

\begin{tabular}{|c|c|}
\hline $\begin{array}{l}\text { DEPARTMENT OF NATURAL RESOURCES: } \\
\text { DIVISION OF WATER RIGHTS: }\end{array}$ & 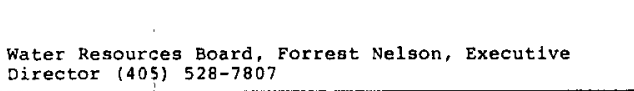 \\
\hline DEPARTMENT OF ENYIRONMENTAL PROTECTION: & 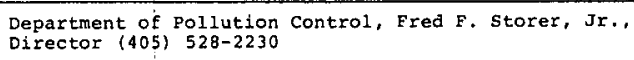 \\
\hline OFF ICE OF ENBREY POLICY: & 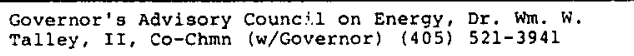 \\
\hline PLLANNING BUREAU: & 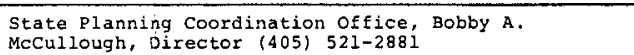 \\
\hline GEOLOGICAL SURVEY: & Dr. Charles $J$. Mankin, Director (405) 325-3031 \\
\hline 政 & Richard $G \cdot$ : $: 111$, Director $(405) 521-3941,2995$ \\
\hline
\end{tabular}

LEGILATIVE CONTACIS

\begin{tabular}{|c|c|}
\hline 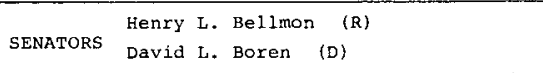 & COOYERNOR George Nigh (D) \\
\hline $\begin{array}{l}\text { CONGRESSMEN (DIST.) } \\
1 \text { - Janes R. Jones (D) }\end{array}$ & \\
\hline $\begin{array}{ll}2-\text { Mike synar } & \text { (D) } \\
3-\text { wesley Q Watkins } & \text { (D) }\end{array}$ & \\
\hline $\begin{array}{l}4-\text { Dave Mccurdy (D) } \\
5-\text { Mavvin H. (Mickey) Eawards (R) }\end{array}$ & \\
\hline $6-$ Glenn Bnglish (D) & \\
\hline
\end{tabular}



III. STATE FUEL PRODUCTION (1973) (C-6)

Type Number Units $\quad$ B.tu

Coal mines

Natural gas (liq.)

Natural gas wells

Crude oil wells

$$
\begin{array}{r}
59 \\
- \\
8,868 \\
72,880
\end{array}
$$
9,319 thousand tons
$-\quad 43,718$ thousand bb1
3,319 thousand tons
$-\quad 43,718$ thousand bb1 $1,770,980$ million cu. ft. 191,204 thousand bbl

Trillion

83.8

176.3

$1,935.7$

$1,109.0$

IV. $\quad$ GEOLOGY

The geologic setting of oklahoma is dominated by the northwest trending Anadarko Basin, which attains depths in excess of 25,000 ft. in the central part of the state where it has been downdropped (faulted) adjacent to the Wichita Uplift. In the southeastern part of the state, the Ouachita Mountains have been thrustfaulted up and over the east-to-west trending Arkoma Basin, which also exceeds 25,000 ft. depth.

V. RESOURCE DATA

Oil and gas exploration in Oklahoma has defined the existence of hot water at depth. Thermal gradients above $1.6^{\circ} \mathrm{F} / 100$ ft. exist in several parts of the state. It is likely that water at temperatures above $200^{\circ} \mathrm{F}$ occurs at depths of $10,000 \mathrm{ft}$. in several parts of the state.

VI. GEOTHERMAL ACTIVITY

1. State-Coupled Resource Assessment Program planned for FY 1980 .

VII. LEGAL ACTIVITIES

To be determined.

VIII. CONTACTS

1. Water Resources Board, Forrest Nelson, Executive Director, (405) 528-7807.

2. Department of Pollution Control. Fred F. Storer, Jr., Director, (405) 52:8-2230.

3. Governor's Advisory Council on Energy. Dr. William W. Talley, II, Co-Chairman (w/Governor), (4:05) 521-3941. 
4. State Planning Coordination Office, Bobby A. McCullough, Director, (405) 521-2881.

5. Geological Survey, Dr. Charles J. Mankin, Director, (405) 325-3031.

6. Department of Energy, Richard G. Hill, Director, (405) $521-3941,2995$.

REFERENCES AND LIST OF SIGNIFICANT REPORTS

Common references only, see below.

COMMON REFERENCES

$(C-4),(c-6)$, and $(C-7)$. 
State Geothermal Fact Sheet

OREGON

I. DEMOGRAPHIC INFORMATION (1970) (C-4)

TOTAL STATE

Population: 2,091,385 Area: 96,184 sq. mi. Density: 22 per sq. mi.

GEOTHERMAL RESOURCE AREA

Population:

Area :

sq. mi. Density:

per sq. mi.

II. ENERGY CONSUMPTION* (1975) (C-7)

\begin{tabular}{|c|c|c|c|c|c|}
\hline & $\begin{array}{l}\text { OIL } \\
\text { (million } \\
\text { bbl) }\end{array}$ & $\begin{array}{l}\text { LPG } \\
\text { (million } \\
\text { gal.) }\end{array}$ & $\begin{array}{c}\text { GAS } \\
\text { (trillion } \\
\text { cu.ft.) }\end{array}$ & $\begin{array}{l}\text { COAL } \\
\text { (million } \\
\text { tons) }\end{array}$ & $\begin{array}{r}\text { ELECTRICI } \\
\text { PURCHASE } \\
\text { (billion k }\end{array}$ \\
\hline $\begin{array}{l}\text { GROSS } \\
\text { Residential } \\
\text { Commerical } \\
\text { Industrial }\end{array}$ & $\begin{array}{r}49 \\
3 \\
4\end{array}$ & $\begin{array}{r}31 \\
16 \\
2\end{array}$ & $\begin{array}{r}114 \\
29 \\
16\end{array}$ & $\begin{array}{l}0 \\
0 \\
0\end{array}$ & $\begin{array}{r}32 \\
12 \\
8\end{array}$ \\
\hline \multicolumn{6}{|c|}{ Trillion Btu } \\
\hline $\begin{array}{l}\text { GROSS } \\
\text { Residential } \\
\text { Commercial } \\
\text { Industrial }\end{array}$ & $\begin{array}{r}268 \cdot 7 \\
16 \cdot 1 \\
26.2\end{array}$ & $\begin{array}{l}2.9 \\
1.5 \\
0.2\end{array}$ & $\begin{array}{r}117.5 \\
29.7 \\
16.4\end{array}$ & $\begin{array}{l}2.0 \\
0.1 \\
0.1\end{array}$ & $\begin{array}{r}110 \cdot 6 \\
41 \cdot 8 \\
27.2\end{array}$ \\
\hline Percentages & 68 & 1 & 30 & 1 & \\
\hline
\end{tabular}

*Excluding nuclear and hydro electricity, coking coal and petroleum coke, and other petroleum products not used as fuels. 
III. STATE FUEL PRODUCTION (1973) $(\mathrm{C}-6)$

Type Number Units $\quad$ Btu

Coal mines

Natural gas (liq.)

Natural gas wells

Crude oil wells

\section{0}

0

0
0 thousand tons 0

0 thousand bbl 0

0 million cu. ft. 0

0 thousand $\mathrm{bbl} \quad 0$

IV. $\quad$ GEOLOGY

The geologic provinces within oregon containing geothermal resources are the Cascade Range, the Basin-and-Range Province, the High Lava Plains, and several provinces that lie in the northeastern part of the state. Many major volcanic centers and cones of late Tertiary to Quaternary age, hot springs and associated KGRA's occur in all these areas. Pleistocene to Holocene volcanic flows and pyroclastic rocks cover large areas in the Cascades and $\mathrm{High}$ Lava Plains.

The north-south trending Cascade Range coincides with a large region of high heat flow ( $>2.5 \mathrm{HFU}$ ) and several smaller anomalies occur to the east. Many low temperature geothermal resource areas consisting of hydrothermal resources in aquifers at shallow depths $(<1 \mathrm{~km})$ also occur in these ranges.

In contrast to the volcanic centers, long-range-front, normal and strike-slip faults play a very important role in the circulation of fluids in the Basin-and-Range Province.

Several large geothermal resources in the High Lava Plains occur along the $300 \mathrm{~km}$ Brothers Fault Zone, which is the northern border of the Basin-and-Range Province and which consists of a series of en echelon normal faults above a major crustal shear.

V. RESOURCE DATA

To be determined.

VI. GEOTHERMAL ACTIVITY

To be determined.

VII. IEGAL ACTIVITIES

To be determined. 
VIII. CONTACTS

To be determined.

REFERENCES AND LIST OF SIGNIFICANT REPORTS

(1) Debra Justus, "Geothermal Resources in Oregon: Site Data Base and Development Status," Geo-Heat Utilization Center, Klamath Falls, OR, Apr 1979.

COMMON REFERENCES

$(C-4),(C-6)$, and $(C-7)$. 
ENERGY RESOURCES-1973
ANNUAL PBOOUCTON
An

\begin{tabular}{|c|c|c|c|}
\hline \multicolumn{4}{|c|}{$\begin{array}{l}\text { ENEGAY RESORCCES-1973 } \\
\text { ENNUA PRODUCTION }\end{array}$} \\
\hline$T_{Y}$ & NUMBER & Status & $110^{12} \mathrm{Btu}$ \\
\hline Coal Mines & 916 & .096 thousand tons & $2,184.6$ \\
\hline Natura1 Gas 12 & & 44 thousand bbl & 0.2 \\
\hline Natura1 & 16,600 & 78,514 million cu. $\mathrm{ft}$. & 85.8 \\
\hline crude oil wells & 31,539 & 3,282 thousand bb1 & 19 \\
\hline
\end{tabular}

NERGY USE - 1975 (10" ATU

\begin{tabular}{|c|c|c|c|c|c|}
\hline SECTOR & ort & ${ }_{\mathrm{LPG}}$ & Gas & $\cos x$ & $\begin{array}{l}\text { ELECE. } \\
\text { EURCH: }\end{array}$ \\
\hline GROss & 1284.9 & 21.2 & 6776.8 & $\begin{array}{l}1676.9 \\
\end{array}$ & 300.4 \\
\hline RESSDENTIAL & 172.5 & 9.0 & 281.4 & 26.7 & 94.6 \\
\hline COMMERCTAI & 142.7 & 1.0 & 102.2 & 27.3 & 62.8 \\
\hline InDUSTRRAI & 140.3 & 11.0 & 273.8 & 156.1 & 141.0 \\
\hline 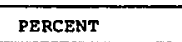 & & 2 & 18 & 10 & \\
\hline
\end{tabular}

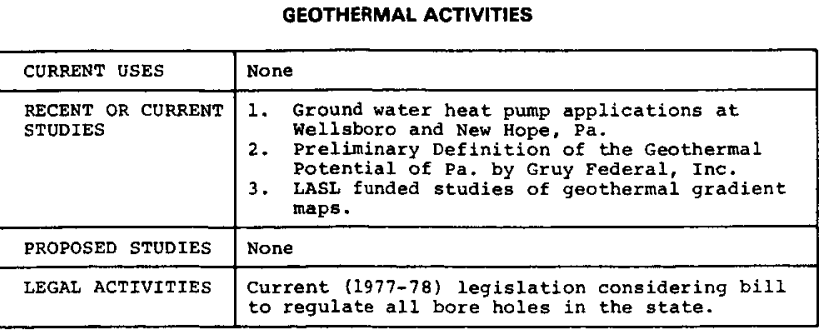

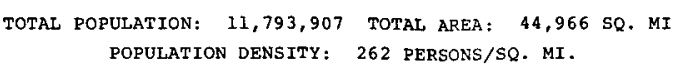

\section{GEOTHERMAL OVERVIEW}

The Appalachian Basin lies beneath the western two-thirds
of Pennsyyvania aver age geothermal gradient coincide with great thicknesses with large load centers. These areas have potential tor tor utilization of the thermal energy as a hydrothermal $r$ -

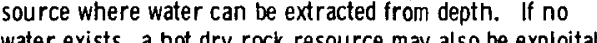

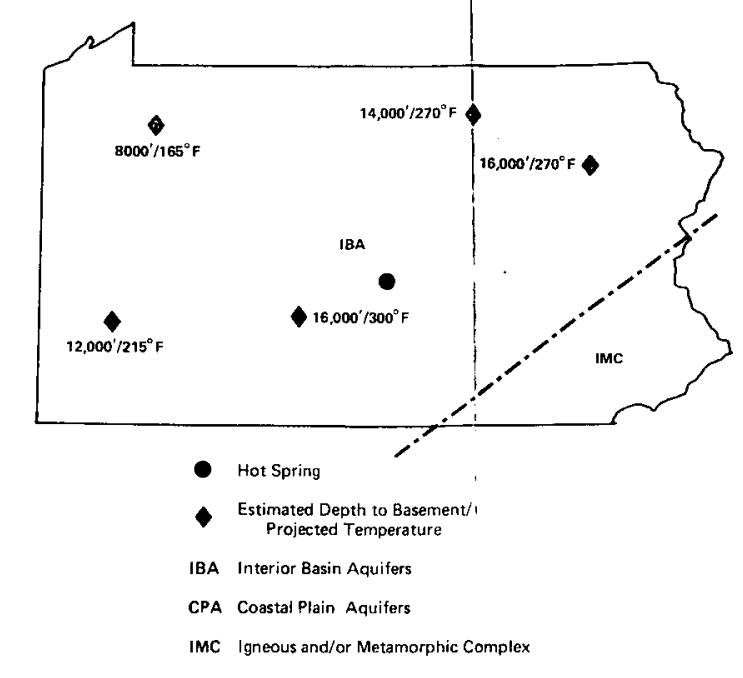

PRIMARY CONTACTS

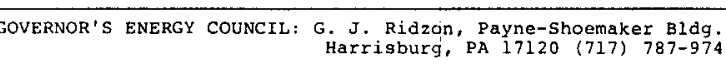

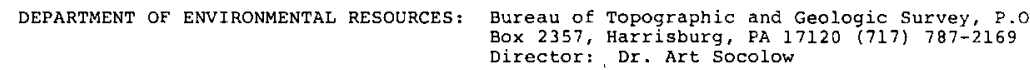

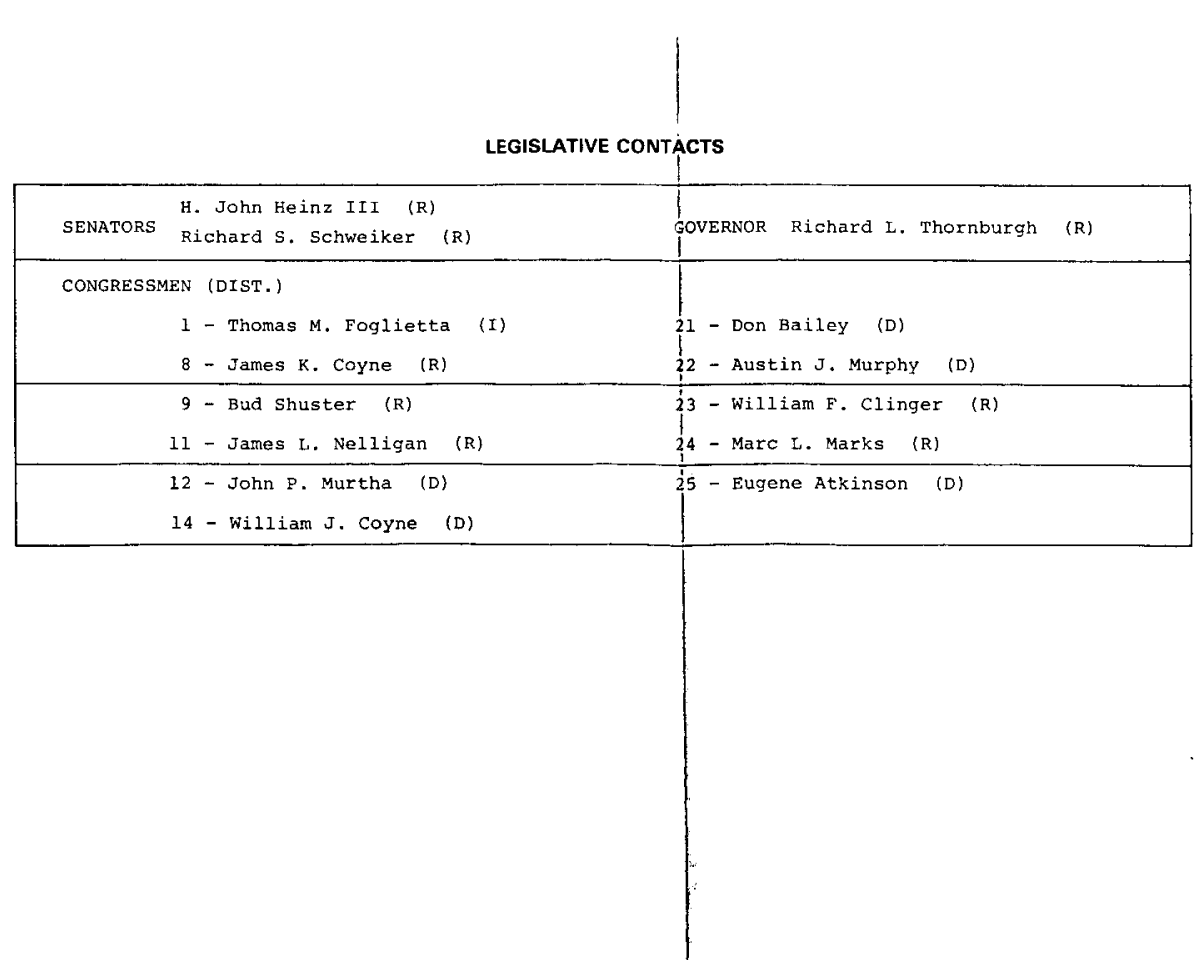


State Geothermal Fact sheet

PENNSLYVANIA

I. DEMOGRAPHIC INFORMATION (1970) (C-4)

TOTAL STATE

Population: 11,793,907 Area: 44,966 sq. mi. Density: 262 per sq. mi.

GEOTHERMAL RESOURCE AREA

Population: 2,000,000+ Area: 14,500+sq. mi. Density: 130 per sq. mi.

II. ENERGY CONSUMPTION* (1975) (C-7)

\begin{tabular}{cccccc}
\hline & $\begin{array}{c}\text { OII } \\
\text { (million } \\
\text { bbl) }\end{array}$ & $\begin{array}{c}\text { LPG } \\
\text { (million } \\
\text { gal.) }\end{array}$ & $\begin{array}{c}\text { GAS } \\
\text { (trillion } \\
\text { cu.ft.) }\end{array}$ & $\begin{array}{c}\text { COAL } \\
\text { (million } \\
\text { tons) }\end{array}$ & $\begin{array}{c}\text { ELECTRICITY } \\
\text { PURCHASED } \\
\text { (billion kWh) }\end{array}$ \\
GROSS & 228 & 222 & 656 & 67 & 88 \\
Residential & 30 & 94 & 273 & 1 & 28 \\
Commerical & 24 & 10 & 99 & 1 & 18 \\
Industrial & 23 & 115 & 265 & 6 & 41
\end{tabular}

Trillion Btu

\begin{tabular}{|c|c|c|c|c|c|}
\hline $\begin{array}{l}\text { GROSS } \\
\text { Residential } \\
\text { Commercial } \\
\text { Industrial }\end{array}$ & $\begin{array}{r}1284.9 \\
172.5 \\
142.7 \\
140.3\end{array}$ & $\begin{array}{r}21.2 \\
9.0 \\
1.0 \\
11.0\end{array}$ & $\begin{array}{l}676.8 \\
281 \cdot 4 \\
102 \cdot 2 \\
273.8\end{array}$ & $\begin{array}{r}1676.9 \\
26.7 \\
17.3 \\
156.1\end{array}$ & $\begin{array}{r}300.4 \\
94.6 \\
61.8 \\
141.0\end{array}$ \\
\hline
\end{tabular}

$\begin{array}{lllll}\text { Percentages } & 35 & 1 & 18 & 46\end{array}$

*Excluding nuclear and hydro electricity, coking coal and petroleum coke, and other petroleum products not used as fuels. 
III. STATE FUEL PRODUCTION (1973) (C-6)

\section{Type}

Coal mines

Natural gas (liq.)

Natural gas wells

Crude oil wells
Number

916
-
16,600
31,539

Units

82,096 thousand tons

44 thousand bbl

78,514 million cu. ft.

3,282 thousand bbl
Trillion Btu

$2,184.6$

0.2

85.8

19

IV. GEOLOGY

Pennsylvania spans four geologic provinces. In the southeast a thin veneer of Coastal plain sediments (Cretaceous and younger) onlaps the metamorphic and igneious rocks of the Piedmont (late Precambrian to Paleozoic). West of the Piedmont lies a narrow belt of Precambrian rocks of Grenville age (about 1.1 billion years - bp) known to the south as the Blue Ridge and in eastern Pennsylvania as the Reading Prong. Two fault bounded basins occur along the boundary of the Piedmont and the Grenville age rocks. These basins (Newark and Gettysburg Basins) contain sedimentary and igneous rocks of Triassic and Jurassic age. The rest of the state is underlain by the Paleozoic sedimentary rocks of the Appalachian Basin. The thickness of this large asymmetric basin exceeds $30,000 \mathrm{ft}$. along its eastern margin but thins to less than 10,000 ft. in the northwest corner of the state. A few small Mesozoic dikes (kimberlites) do cross-cut the sedimentary rocks of this basin.

Potentially exploitable geothermal resources are most likely to exist beneath the Appalachian, Newark, and Gettysburg sedimentary basins.

V. RESOURCE DATA

Limited geothermal gradient data are available for the Newark and Gettysburg Basins, although project contours range from 1.2 to $2.2^{\circ} \mathrm{F} / 100 \mathrm{ft}$. for this region. The sediments in these basins attain thicknesses greater than 15,000 ft. Thus, assuming a conservative estimate for the thermal gradient of $1.2^{\circ} \mathrm{F} / 100 \mathrm{ft}$., in that area, temperatures at the base of the sedimentary pile may be predicted to be at least $230^{\circ} \mathrm{F}$. If an ideal situation of a $2.2^{\circ} \mathrm{F} / 100 \mathrm{ft}$. gradient coincident with the deeper parts of the basin $(15,000 \mathrm{ft.})$ is assumed, temperatures may exist as high as $350^{\circ} \mathrm{F}$. Since these basins are interpreted to have been formed by movement on deep crustal fault zones, higher gradients caused by circulation along deep seated faults may be expected locally. 
The Appalachian Basin attains sedimentary thicknesses greater than 30,000 ft. A broad area of elevated thermal gradients $\left(>1.6^{\circ} \mathrm{F} / 100 \mathrm{ft.}\right)$ coincides with population centers and sedimentary sequences greater than 10,000 ft. thick. Near Scranton, with a $1.8^{\circ} \mathrm{F} / 100 \mathrm{ft}$. gradient, temperatures of $230^{\circ} \mathrm{F}$ to $320^{\circ} \mathrm{F}$ (at 10,000 ft. and 15,000 ft., respectively) may be encountered.

The availability of extractable water at these depths and in these places is unknown, but large quantities have been encountered in deep oil and gas exploration.

VI. GEOTHERMAL ACTIVITY

Recent studies: $\quad$ 1. Ground water heat pump applications at Wellsboro and New Hope, Pa.

2. Preliminary Definition of the Geothermal Potential of Pa. by Gruy Federal, Inc.

3. LASL funded studies of geothermal gradient maps.

VII. LEGAL ACTIVITIES

Current (1977-78) legislature is considering a bill to regulate all bore holes in the state.

VIII. CONTACTS

1. Governor's Energy Council, Payne-Shoemaker Bldg., Harrisburg, PA 17120, G. J. Ridzon, (712) 787-9749.

2. Department of Environmental Resources, Bureau of Topographic and Geologic Survey, P.O. Box 2357, Harrisburg, PA 17120, A. A. Socolow, Director, (717) 787-2169.

REFERENCES AND LIST OF SIGNIFICANT REPORTS

(1) "Preliminary Definition of the Geothermal Resources Potential of Pennslyvania: 1979," Gruy Federal Inc., NVO-1558-6.

COMMON REFERENCES

$(C-4),(C-6)$, and $(C-7)$. 


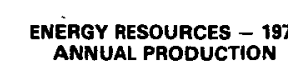
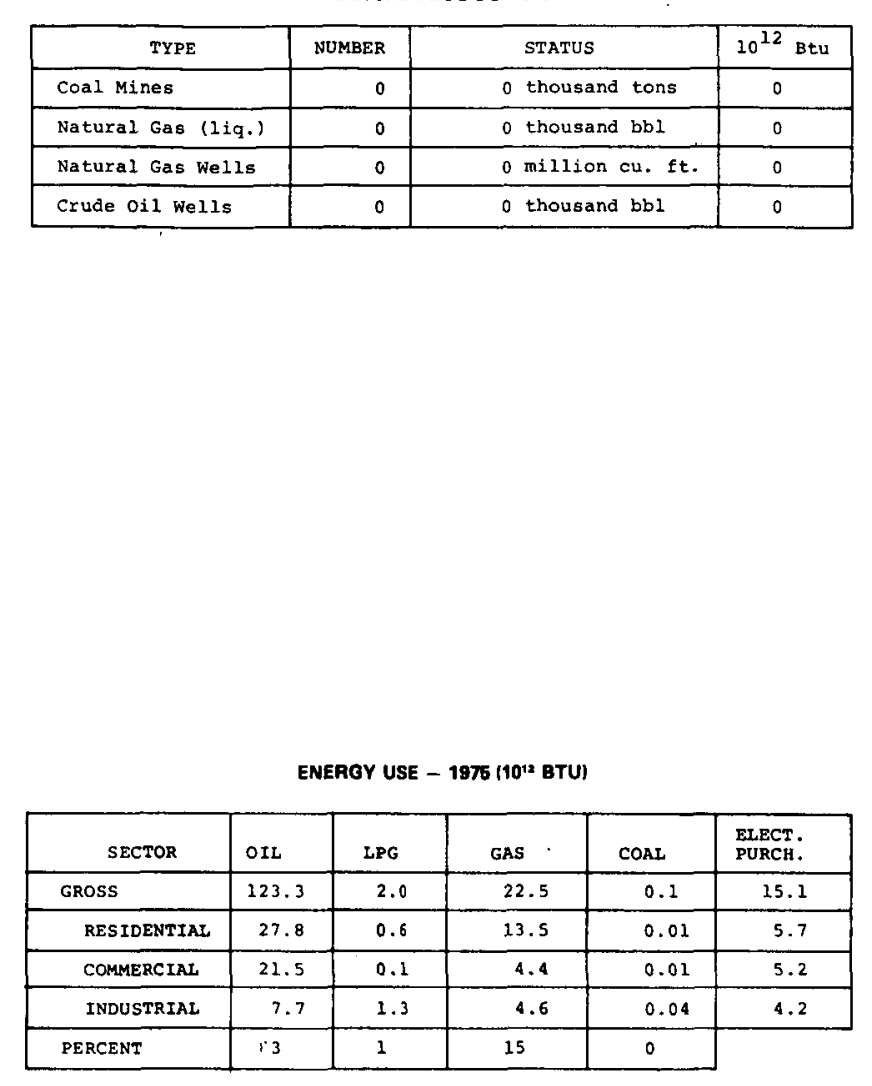

GEOTHERMAL ACTIVTTES

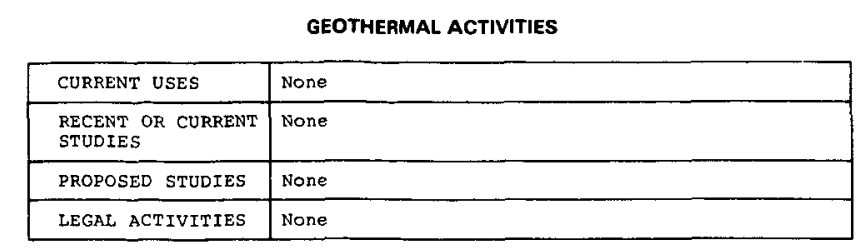

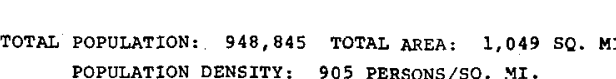

GEOTHERMAL OVERVIEW

The north-south trending Narragansett Basin in the middlle 

III. STATE FUEL PRODUCTION (1973) $(\mathrm{C}-6)$

$\begin{array}{ccc}\text { Type Number Units } & \text { Trilion } \\ \text { Btu }\end{array}$

Coal mines

Natural gas (liq.)

Natural gas wells

Crude oil wells
0

0

0

0

0 thousand tons

0 thousand bbl

0 milizon cu. ft.

0 thousand $\mathrm{bbl}$

0

0

0

0

IV. GEOLOGY

To be supplied.

V. RESOURCE DATA

To be supplied.

VI. GEOTHERMAL ACTIVITY

To be determined.

VII. LEGAL ACTIVITIES

To be determined.

VIII. CONTACTS

1. Department of Natural Resources, Edward Wood, Director, (401) 277-2771.

2. Division of Water Rights, Robert Russ, General Manager, (401) 277-2217.

3. State Energy Office, Dante Jonata, Director, (401) 277-3374.

4. Statewide Planning Program. Daniel Varin, Chief, (401) 277-2656.

5. Geological Survey, Robert L. McMaster, Associate State Geologist for Marine Affairs, (401). 722-3142.

REFERENCES AND LIST OF SIGNIFICANT REPORTS

Common references only, see below.

COMMON REFERENCES

$(C-1),(C-4),(C-6),(C-7)$, and $(C-10)$.

RI-2 


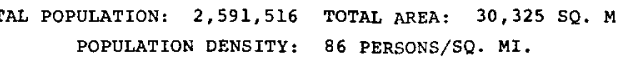

\begin{tabular}{|c|c|}
\hline PAME & Cosasta1 plain-char leston, Georgetown Area \\
\hline $\begin{array}{l}\text { TYPE } \\
\end{array}$ & Clastic and carbonate sediments \\
\hline DEPFH & 3000 ft. \\
\hline WATER TEMP. & 107 to $103^{\circ} \mathrm{F}$ \\
\hline $\begin{array}{l}\text { EST STSOORED } \\
\text { WATRR }\end{array}$ & \\
\hline $\begin{array}{l}\text { EST. ENERGY } \\
\text { COOTRENT }\end{array}$ & $<1.0$ quad \\
\hline
\end{tabular}

ENERGY RESOURCES - 199
ANNUAL PROOUCTION

\begin{tabular}{|c|c|c|c|}
\hline TYYPE & RUMBER & straus & ${ }_{10^{12}} \mathrm{Btu}$ \\
\hline cool mines & 0 & 0 thousand tons & \\
\hline Naturat Gas (1iq.) & 0 & 0 thousand bb1 & $\circ$ \\
\hline Natural Gas we11s & 0 & 0 mil11ion cu. $\mathrm{ft}$. & 0 \\
\hline Crude oil we $11 \mathrm{~s}$ & 0 & 0 thousand bb1 & 0 \\
\hline
\end{tabular}

NERQV USE - 1975 10" BTU

\begin{tabular}{|c|c|c|c|c|c|}
\hline SECEOR & OIL & LPG & GAS & $\cos x$ & $\begin{array}{l}\text { ELECCE. } \\
\text { PUCHA }\end{array}$ \\
\hline Gross & 306.0 & 12.7 & 131.2 & 141.3 & 101,1 \\
\hline RESIDENTIAL & 19.7 & 7.4 & 18.8 & 3.0 & 33.1 \\
\hline COMMERCIAL & 3.5 & 0.8 & 17.8 & 1.6 & 21.8 \\
\hline INDUSTRIAL & 25.1 & 4.3 & 76.9 & 28.8 & 46.2 \\
\hline PERCENT & 52 & 2 & 22 & 24 & \\
\hline
\end{tabular}

GEOTHERMAL ACTVITTES

\begin{tabular}{|c|c|}
\hline CURRENY USES & None \\
\hline 苜CCEFT OR CURRENT & 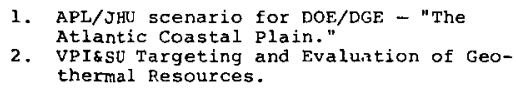 \\
\hline PROPOSED STUDIES & 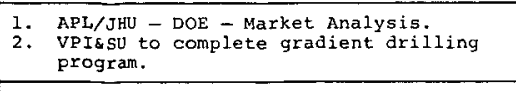 \\
\hline LEGAL ACTIVITIES & NcSL - conducting workshops in 1980. \\
\hline
\end{tabular}

Above aver age geothermal gradients occur in the cosstal
SOUTH CAROLINA

GEOTHERMAL DATA SUMMARY SHEET

(cf. Stete Geothermal Fact sheet, south Caroling

GEOTHERMAL OVERVIEW Plain sediments, however. this sequence is shall ow and
the potential for hydrothermal resurce is restricted.

SOUTH CAROLINA
PRIMARY CONTACTS

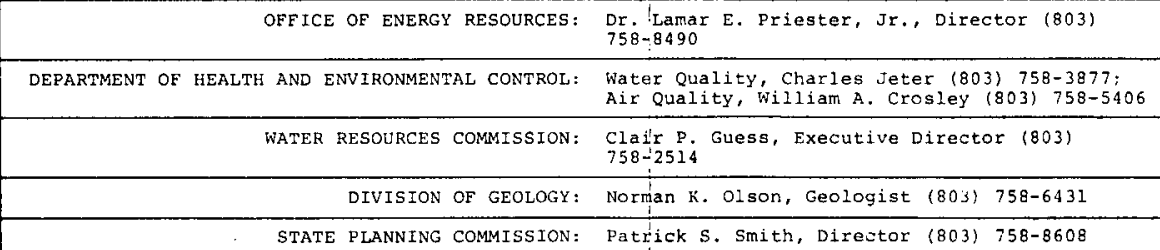

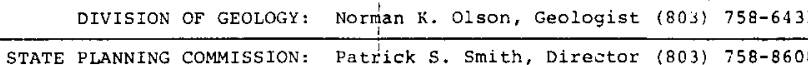

LEGILATIVE CONTACTS

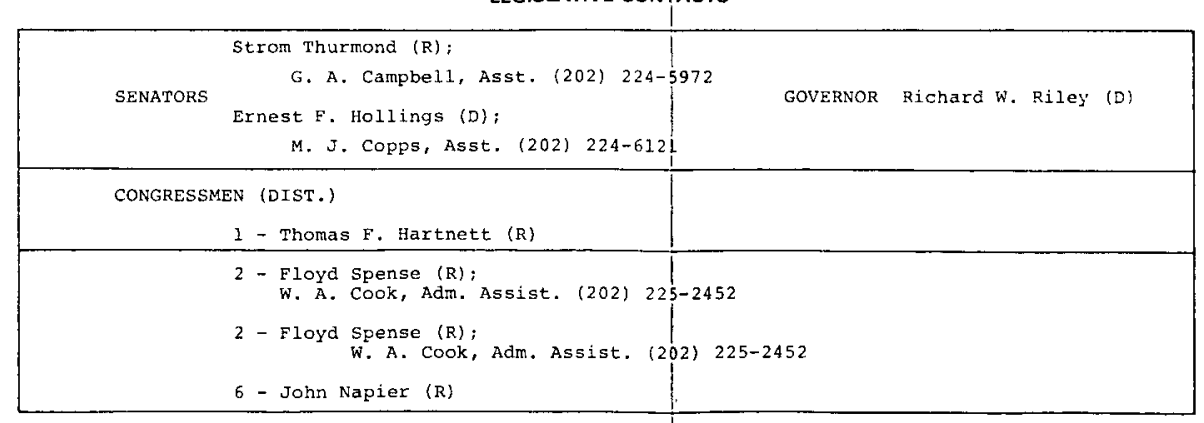


State Geothermal Fact sheet

SOUTH CAROLINA

I. DEMOGRAPHIC INFORMATION (1970) (C-4)

TOTAL STATE

Population: 2,591,516 Area: $30,325 \mathrm{sq} \cdot \mathrm{mi}$. Density: 86 per sq. mi. GEOTHERMAL RESOURCE AREA

Population: 460,268 Area: $5,110 \mathrm{sq} \cdot \mathrm{mi}$. Density: $91 \mathrm{per} \mathrm{sq} \cdot \mathrm{mi}$.

II. ENERGY CONSUMPTION* (1975) (C-7)

\begin{tabular}{|c|c|c|c|c|c|}
\hline & $\begin{array}{c}\text { OIL } \\
(\mathrm{million} \\
\text { bbl) }\end{array}$ & $\begin{array}{c}\text { LPG } \\
\text { (million } \\
\text { gal.) }\end{array}$ & $\begin{array}{c}\text { GAS } \\
\text { (tri.lion } \\
\text { cu.ft.) }\end{array}$ & $\begin{array}{c}\text { COAL } \\
\text { (million } \\
\text { tons) }\end{array}$ & $\begin{array}{l}\text { ELECTRIC } \\
\text { PURCHAS } \\
\text { (billion }\end{array}$ \\
\hline $\begin{array}{l}\text { GROSS } \\
\text { Residential } \\
\text { Commerical } \\
\text { Industrial }\end{array}$ & $\begin{array}{l}56 \\
3 \\
0.6 \\
4\end{array}$ & $\begin{array}{r}133 \\
78 \\
9 \\
45\end{array}$ & $\begin{array}{r}1: 27 \\
18 \\
17 \\
74\end{array}$ & $\begin{array}{l}6 \\
0.1 \\
0.06 \\
1\end{array}$ & $\begin{array}{r}30 \\
10 \\
7 \\
13\end{array}$ \\
\hline \multicolumn{6}{|c|}{ Trillion Btu } \\
\hline $\begin{array}{l}\text { GROSS } \\
\text { Residential } \\
\text { Commercial } \\
\text { Industrial }\end{array}$ & $\begin{array}{r}306.0 \\
19.7 \\
3.5 \\
25.1\end{array}$ & $\begin{array}{r}12.7 \\
7.4 \\
0.8 \\
4.3\end{array}$ & $\begin{array}{r}131.2 \\
18.8 \\
17.8 \\
76.9\end{array}$ & $\begin{array}{r}141.3 \\
3.0 \\
1.6 \\
28.8\end{array}$ & $\begin{array}{r}101 . \\
33 \\
21 \\
46\end{array}$ \\
\hline
\end{tabular}

Percentages 52

2

22

24

*Excluding nuclear and hydro electricity, coking coal and petroleum coke, and other petroleum products not used as fuels. 
III. STATE FUEL PRODUCTION (1973) $(\mathrm{C}-6)$

Type Number

Coal mines

Natural gas (liq.)

Natural gas wells

Crude oil wells
Units

Trillion Btu

0 thousand tons

0 thousand bbl

0 million cu. ft.

0 thousand bbI
0

0

0

0

IV. GEOLOGY

Detailed coastal zone information not known at this time. For piedmont geology see (I).

V. RESOURCE DATA

The promising areas for geothermal development are the Georgetown and Charleston areas where maximum well temperatures of 107 and $123^{\circ} \mathrm{F}$ have been measured. Basement in those areas is rather shallow, 2000 to 3000 ft. Available energy is estimated to be small, a fraction of a quad. The Charleston area is an area of significant seismic activity.

VI. GEOTHERMAL ACTIVITY

The DOE/DGE Gradient Well Program, conducted by Gruy Federal, did not extend into South Carolina. During CY 1980, VPI\&SU planned to drill five $1000 \mathrm{ft}$. gradient wells in the South Carolina Coastal plain. This program is in process, but its contributions to the information of the gradient map in references $(C-1)$ or (3) are not yet available. As stated in item $V$, the estimated basement depth for the coastal plains does not exceed 2000 to $3000 \mathrm{ft}$. anywhere and is less over most of the coastal plain.

VII. LEGAL ACTIVITIES

None, but a NCSI geothermal workshop is scheduled for 1980 .

VIII. CONTACTS

1. Office of Energy Resources, 1205 Pendleton St., Columbia, SC 29201, Lamar E. Priestor, Jr., Director, (803) $758-849.0$.

2. Natural Resources (Dept. of Wildlife and Marine Resources), Dutch Plaza, \#150, Box 167, Columbia, SC 29202, James A. Timmerman, Executive Director, (803) 758-6291. 
3. Water Resources Commission, 3830 Forest Drive, Box 4515, Columbia, SC 29204, Clair P. Guess, Executive Director, (803) $758-2514$.

4. Department of Health and Environmental Control, 2600 Bull st., Columbia, SC 29201, William A. Crosby, Air Quality Control, (803) 758-5406; Charles Jetor, Water Quality Control, (803) 758-3877.

5. State Planning Division, 211 Wade Hampton Office Bldg., P.O. Box 11333, Columbia, SC 29211, Patrick C. Smith, Director, (803) 758-8608.

6. Division of Geology, State Development Board, Harbison Forest Road, Columbia, SC 29210, Norman K. Olson, Geologist, (803) 758-6431.

7. Public Service Commission, 'Owen Building, Drawer 11649, Columbia, SC 29211, Fred A. Fuller, Chairman, (803) 758-362l.

8. State Coupled Reservoir Assessment Program, VPI\&SU, Dr. John Costain, Geothermal Program Director, Blacksburg, VA, (703) 961-5096.

REFERENCES AND LIST OF SIGNIFICANT REPORTS

(1) "Evaluating and Targeting of Geothermal Resources in the Southeastern United States," VPI\&SU, DOE Report VPI-SU-5103-2, 1976.

(2) Evaluating and Targeting of Geothermal Energy Resources in the Southeastern United States," VPI\&SU, DOE Report VPI\&SU-78ET-27001, $-7,30$ Sep 1979.

(3) "Geothermal Energy and the Eastern U.S., A Scenario for Geothermal Energy Development, The Atlantic Coastal Plain," APL/JHU QM-77-129, Oct 1977.

(4) "Geothermal Resources of the Eastern United States," Gruy Federal, Inc., Arlington, VA, DOE Report $\mathrm{DOE} / \mathrm{ET} / 28373-\mathrm{T} 2$.

(5) Mid-Atlantic and Southeastern Low-to-Moderate Temperature Program: Geologic Setting and Targeting Procedures," (VPI\&SU, Chapter VII, Geothermal Energy and the Eastern.U.S., Technical Exchange Meeting, Minutes), JHU/APL QM-79-261, Dec 1979. 
THE JOHNS HOPKINS UNIVERSITY

APPLIED PHYSICS LABORATORY

LAUREL, MARYLAND

\section{COMMON REFERENCES}

$$
(C-1),(C-4),(C-6), \text { and }(C-7) \text {. }
$$




\section{I \\ SOUTH DAKOTA}

ENEREY RESOUACES - 1973
ANNUAL PRODUCTION

\begin{tabular}{|c|c|c|c|}
\hline TYPE & NUMBER & stamus & $10^{12}$ Btu \\
\hline Coal Mines & 0 & 0 thousand tons & 0 \\
\hline Natural Gas (1iq.) & - & 0 thousand bb1 & 0 \\
\hline Natura1 Gas wel1s & s & 0 million cu. $\mathrm{ft}$. & 0 \\
\hline Crude oil wel1s & 27 & 275 thousand bby & 1.6 \\
\hline
\end{tabular}

Crude oil kel1s 275 thousand bb1
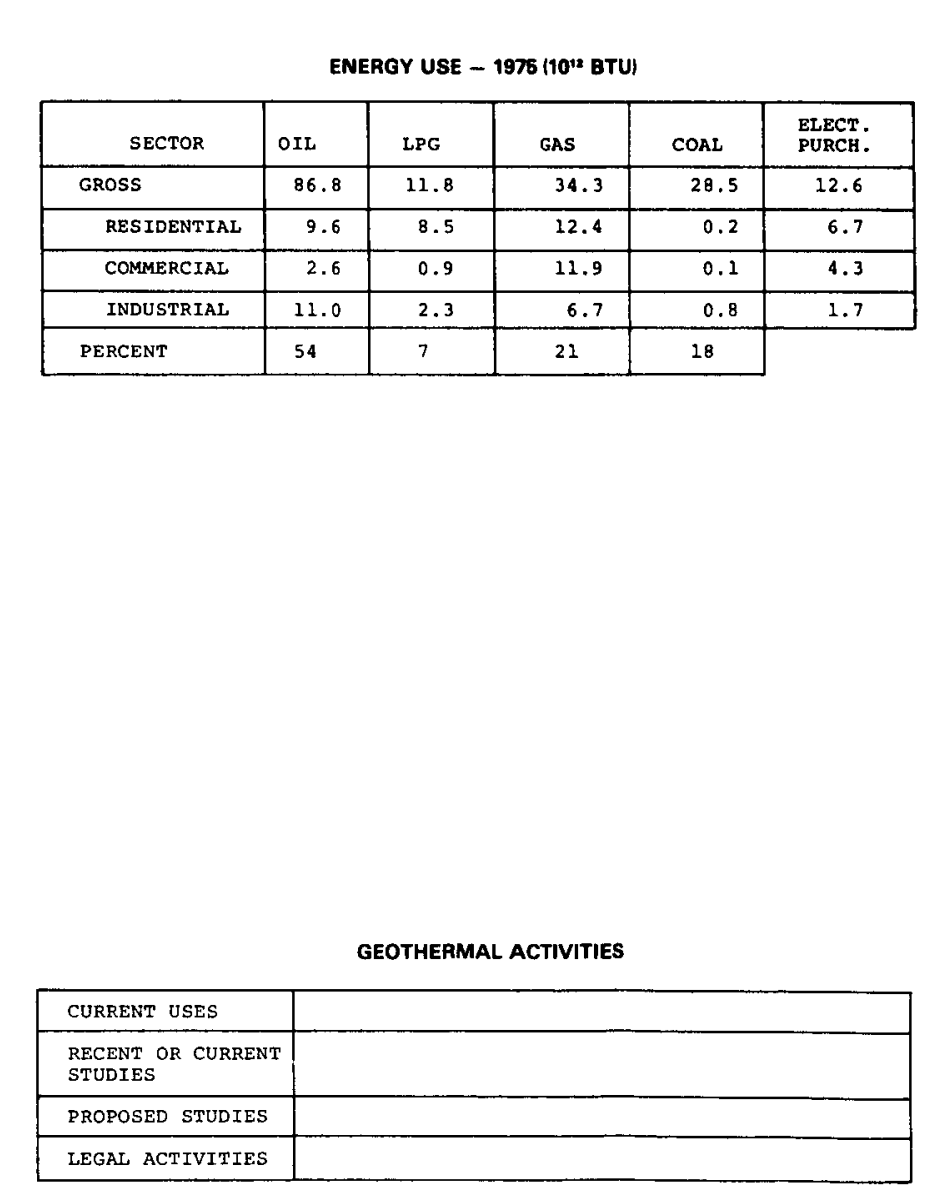

GEOTHERMAL DATA SUMMARY SHEET

TOTAL, POPULATtON: 666, 257 TOTaL AREA: 77,047 SQ. M

\section{GEOTHERMAL OVERVIEW} The Madison Aquifer occurs at depth throughout western
South Dakota. Most properly completed wells encounter artesian waterflow at surface deviations of about 2100 feet or less. Temperatures are low to moder rate with reasonable
potential for space heating applications.
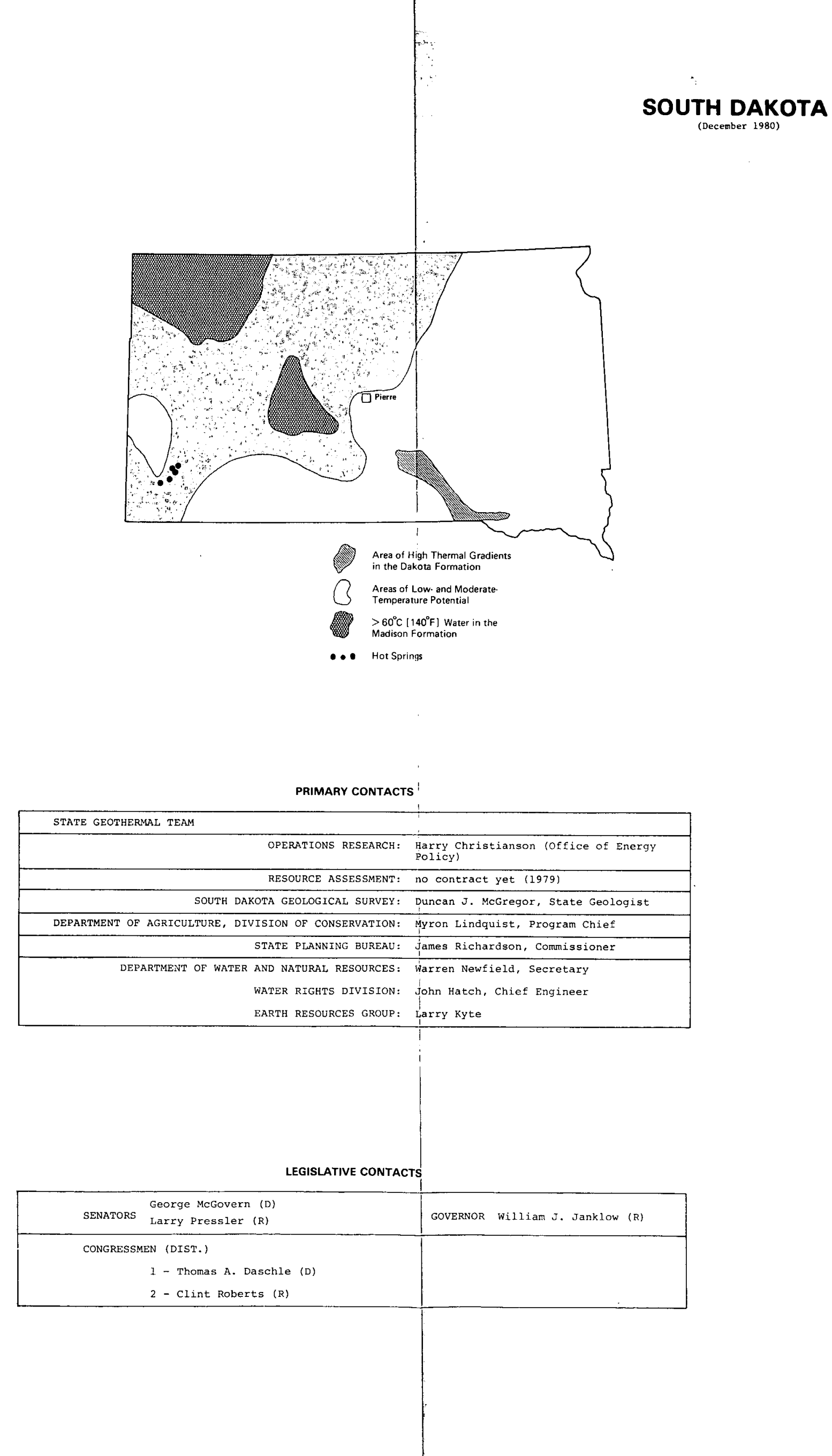
State Geothermal Fact sheet

SOUTH DAKOTA

I. DEMOGRAPHIC INFORMATION (1970) (C-4)

TOTAL STATE

Population: 666,257 Area: $77,047 \mathrm{sq} \cdot \mathrm{mi}$. Density: 8.6 per sq. mi.

GEOTHERMAL RESOURCE AREA

Population:

Area :

$\mathrm{sq} \cdot \mathrm{mi}$.

Density:

per sq. mi.

II. ENERGY CONSUMPTION* (1975) (C-7)

$n$
0
1
1

OIL
(million
bbl)

LPG
(milion
gal.)
123
89
10
24

GAS
(trillion
cu.ft.)
33
12
11
7

$$
\begin{gathered}
\text { COAL } \\
\text { (million } \\
\text { tons) }
\end{gathered}
$$

GROSS

Residential

Commerical

Industrial

16
2
0.5
2

Trillion Btu

\section{GROSS \\ Residential \\ Commercial \\ Industrial}

Percentages

86.8
9.6
2.6
11.0

54

$\begin{array}{rr}11.8 & 34.3 \\ 8.5 & 12.4 \\ 0.9 & 11.9 \\ 2.3 & 6.7\end{array}$

7

21

28.5
0.2
0.1
0.8

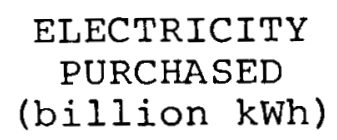

ELECTRICITY

PURCHASED

(billion kWh)

2
0
0
0

*Excluding nuclear and hydro electricity, coking coal and petroleum coke, and other petroleum products not used as fuels. 
III. STATE FUEL PRODUCTION (1973) (C-6)

Type Number

Coal mines

Natural gas (liq.)

Natural gas wells

crude oil welis

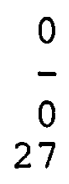

Units

0 thousand tons

0 thousand bbl

0 million cu. ft.

275 thousand bbl
Trillion Btu

0
0
0
1.6

IV. GEOLOGY

All of South Dakota lies in the Great Plains physiographic province. Two main geologic features are of interest: The Black Hills and the Madison group aquifer. The Madison group occurs at depth throughout the western part of the state. It is composed of Mississippian carbonate rocks containing a regionally interconnected network of fracture-and-solution-opening porosity. Artesian waterflow occurs in almost every properly completed well at surface elevation of about $2100 \mathrm{ft}$. or less. Recharge of the Madison comes from the Black Hills where melting snows and rains enter the highly porous rocks that outcrop around the Black Hills uplift. Water flows through the Madison to a depth of more than $3000 \mathrm{ft}$. and, in general, is heated from normal gradient. Water quality tends to deteriorate to the northwest where evaporite beds occur in the upper part of the aquifer. The Dakota Formation in south-central South Dakota contains Inyan Kara Sandstone and Red River Dolomite in which hydrothermal waters have been found.

\section{RESOURCE DATA}

The major hydrothermal resource is the Madison aquifer, which must be considered both as confirmed and of great size. other zones of porosity exist above and below the Madison group and may be of some future use.

\section{GEOTHERMAI ACTIVITY}

Four PoNs were awarded in 1977 by the Department of Energy. Three of these experimental programs have met with reasonable success and have progressed to system design or construction phases (1979).

Two PRDAs were awarded by DOE. One, completed in 1977, was a general assessment of the geologic hydrologic and chemical data for the Madison aquifer and suggested legislative items pertaining to geothermal development. The second, completed in 1979, concentrated on the use of the Madison waters in the town of Edgemont. 
applications.

No federal or state lands have been leased for geothermal

A number of systems is operational: heating schools, homes, and farm and industrial buildings.

VII. LEGAL ACTIVITIES

Specific legislation concerning geothermal resources and applications does not exist.

VIII. CONTACTS

1. State Geothermal Team:

a. Operations Research, Harry Christianson (Office of
Energy Policy);

b. Resource Assessment, no contract yet (1979).

2. South Dakota Geological Survey, Duncan J. McGregor, state Geologist.

3. Department of Agriculture, Division of Conservation, Myron Lindquist, Program Chief.

4. State Planning Bureau, James Richardson, Commissioner.

5. Department of Water and Natural Resources, Warren Newfield, Secretary.

6. Water Rights Division, John Hatch, Chief Engineer.

7. Earth Resources Group, Larry Kyte.

REFERENCES AND LIST OF SIGNIFICANT REPORTS

(1) "South Dakota Hydrothermal Commercialization Baseline," EG\&G Idaho, Inc., Aug 1979.

COMMON REFERENCES

$(C-4),(C-6)$, and $(C-7)$. 
ENERGY RESOUACES-1997
ANNUAL PROOUCTION

\begin{tabular}{|c|c|c|c|}
\hline TYPE & NUMBER & straus & $0^{1{ }^{12}}$ вtu \\
\hline Coal Mines & 119 & 8,217 thousand tons & 215.3 \\
\hline Natural Gas (11q.). & & 0 thousand bb1 & 0 \\
\hline Natural Gas We11s & 6 & 20 milition cu. ft. & 0.0 \\
\hline Crude oil wells & 67 & 201 thousand bb1 & 1.2 \\
\hline
\end{tabular}

TOTAL POPUDAITIN: $\quad 3,923,780$ POTAL AREA: 41,328 SQ. MI.

GEOTHERMAL OVERVIEW A thick sequence of sediments in the eastern and western
portions of the state may represent hydrothermal resource

\begin{tabular}{|c|c|c|c|c|c|}
\hline \multicolumn{6}{|c|}{$3 Y$} \\
\hline secror & ort & LPG & GAS & $\cos x$ & $\begin{array}{l}\text { ELERCT. } \\
\text { PUCCH: }\end{array}$ \\
\hline GRoss & 423.1 & 15.4 & 227.9 & 591.2 & 221.7 \\
\hline RESTDENTIAL & 26.9 & 11.8 & 45.4 & 3.7 & 76.7 \\
\hline COMMERCIAL & 12.8 & 1.3 & 43.9 & 2.0 & 14.8 \\
\hline INDUSTRTAL & 22.8 & 2.1 & 118.9 & 41.9 & 130.2 \\
\hline PBRCENT & 34 & 1 & 18 & 47 & \\
\hline
\end{tabular}
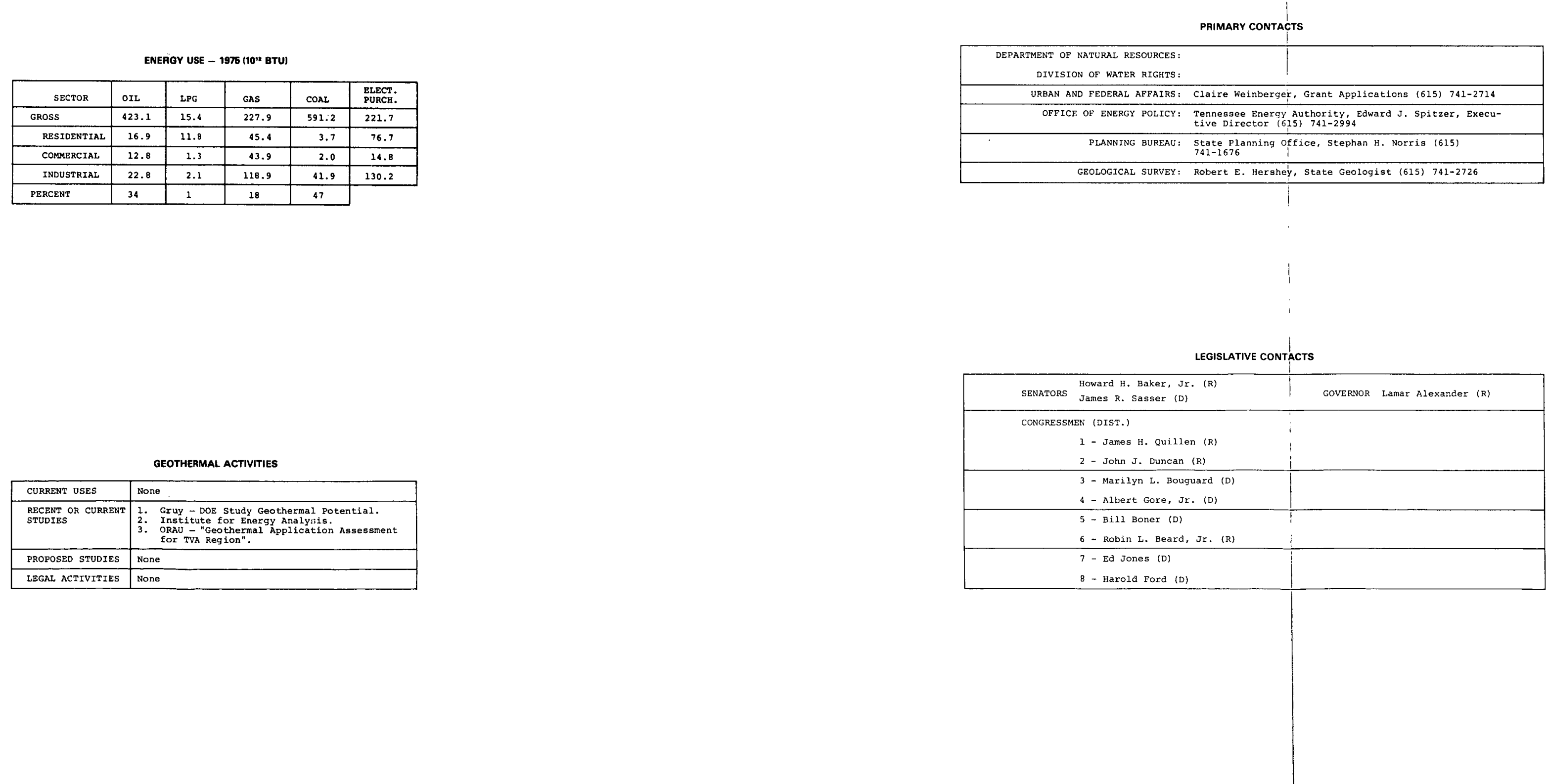
tate Geothermal Fact sheet

TENNES SEE

I. DEMOGRAPHIC INFORMATION (1970) (C-4)

TOTAL STATE

Population: 3,923,780 Area: 41,328 sq. mi. Density: 95 per sq. mi.

GEOTHERMAL RESOURCE AREA

Population:

Area : sq. mi. Density: per sq. mi.

II. ENERGY CONSUMPTION* (1975) (C-7)

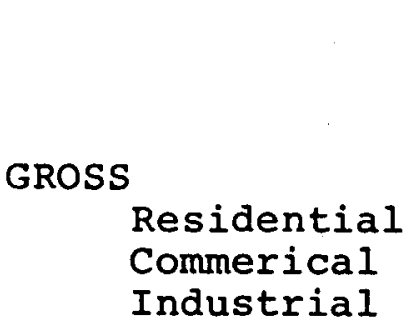

OIL
(million
bbl)

LPG

(million

gal.)

(trilition

161

123

14

cu.ft.)

COAL

(million

tons)

22

44

44
43
75

1.5

ELECTRICITY

PURCHASED

(billion kWh)

Trillion Btu

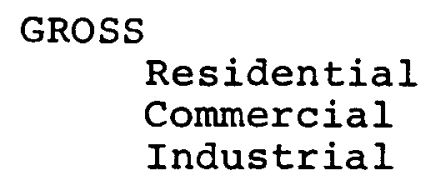

Percentages

$$
\begin{array}{r}
423.1 \\
16.9 \\
12.8 \\
22.8
\end{array}
$$

34

$\begin{array}{rr}15.4 & 227.9 \\ 11.8 & 45.4 \\ 1.3 & 43.9 \\ 2.1 & 118.9\end{array}$

1

18

$$
\begin{array}{r}
591.2 \\
3.7 \\
2.0 \\
41.9
\end{array}
$$

47
27

0.1

0.1

2

65

23

4

38

221.7

76.7

14.8

130.2

*Excluding nuclear and hydro electricity, coking coal and petroleum coke, and other petroleum products not used as fuels. 
III. STATE FUEL PRODUCTION (1973) (C-6)

Type

Coal mines

Natural gas (liq.)

Natural gas wells

Crude oil wells
Number

119

$-$

6

67

Units

Trillion

Btu

215.3

0

0.0

1.2

IV. $\quad$ GEOLOGY

To be supplied.

V. RESOURCE DATA

To be supplied.

VI. GEOTHERMAL ACTIVITY

Current studies: I. Gruy - DOE Study Geothermal Potential.

2. Institute for Energy Analysis.

3. ORAU - "Geothermal Application Assessment for TVA Region."

VII. LEGAL ACTIVITIES

To be determined.

VIII. CONTACTS

1. Urban and Federal Affairs, Claire Weinberger, Grant Applications (615) 741-2714.

2. Office of Energy Policy, Tennessee Energy Authority, Edward J. Spitzer, Executive Director, (615) 741-2994.

3. Planning Bureau, State Planning Office, Stephan $H$. Norris, (615) 741-1676.

4. Geological Survey, Robert E. Hershey, State Geologist, (615) 741-2726. 
THE JOHNS HOPKIIIS UNIVERSITY APPLIED PHYSICS LABORATORY

LAUREL, MARYLAND

REFERENCES AND IIST OF SIGNIFICANT REPORTS

Common references only, see below.

COMMON REFERENCES

$(C-4),(C-6)$, and $(C-7)$. 
GEOTHERMAL RESOURCE DATA

\begin{tabular}{|c|c|c|c|}
\hline NAME & $\begin{array}{c}\text { (1) } \\
\text { Centras } \text { rexas } \\
\text { Resource }\end{array}$ & \begin{tabular}{|l} 
Trans-pecos Region \\
\end{tabular} & \begin{tabular}{|c|c|} 
(3) \\
Culf Coast \\
Region
\end{tabular} \\
\hline TYPE & Cretaceous & Bolson & \begin{tabular}{|c} 
Geopressuread/ \\
sedimentary
\end{tabular} \\
\hline DЕРтH & 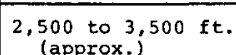 & 3,000 to $9.000 \mathrm{ft}$. & \\
\hline WATER TEMP. & $\angle 150^{\circ} \mathrm{F}$ & 100 to $190^{\circ} \mathrm{B}$ & $>300^{\circ} \mathrm{F}$ \\
\hline $\begin{array}{l}\text { EST. SEORED } \\
\text { WATER }\end{array}$ & & & \\
\hline $\begin{array}{c}\text { EST. ENERGY } \\
\text { CONENT }\end{array}$ & & & \\
\hline
\end{tabular}

ENERGY RESOURCES - 1973
ANNUAL PRODUCTION

\begin{tabular}{|c|c|c|c|}
\hline TYPE & NOMBER & stratus & $10^{12} \mathrm{Btu}$ \\
\hline Coal Mines & & 6.944 thousand tons & 91.7 \\
\hline Natura1 Gas (11q.) & & 314,429 thousand bb1 & $1,268.0$ \\
\hline Natura1 Gas we11s & 23,805 & $8,513,850 \mathrm{mi111ion}$ cu. $\mathrm{ft}$. & $9,305.0$ \\
\hline Crude oil wel15 & 159,090 & $1,294,671$ thousend bb1 & $7,509.1$ \\
\hline
\end{tabular}

\section{ENERGY USE - 1975 (100' BTU)}

\begin{tabular}{|c|c|c|c|c|c|}
\hline SECTOR & OIL & IPG & GAS & COAL & $\begin{array}{l}\text { ELEECT. } \\
\text { PUCCH: }\end{array}$ \\
\hline GRoss & 1691.5 & 115.0 & 4095.8 & 181.5 & 438.0 \\
\hline RESTDENTIAL & 42.7 & 48.5 & 239.8 & 0 & 137.1 \\
\hline COMMERCIAL & 60.6 & 5.4 & 120.5 & 0 & 122.7 \\
\hline INDUSTRIAL & 122.3 & 53.3 & 2254.2 & 36.7 & 178.3 \\
\hline PERCENT & 28 & 2 & 67 & 3 & \\
\hline
\end{tabular}

\begin{tabular}{|c|c|}
\hline \multicolumn{2}{|r|}{ GEOTHERMAL ACTIVITIES } \\
\hline CUREENT USES & $\begin{array}{l}\text { 1. Space and water heating, cotulla High } \\
\text { School } \\
\text { water use for balneological purposes. }\end{array}$ \\
\hline $\begin{array}{l}\text { REECENT OR CURRENT } \\
\text { STODDES }\end{array}$ & 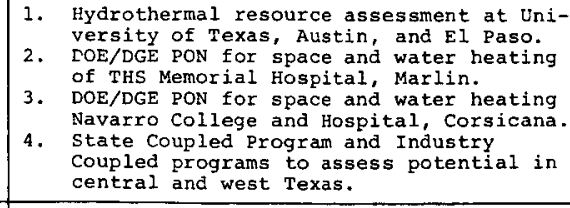 \\
\hline PROPOSED STUDIES & 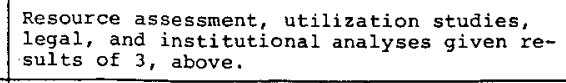 \\
\hline LiEGAL ACTIVITTIES & 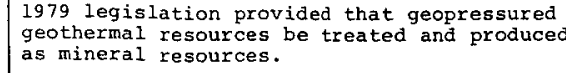 \\
\hline
\end{tabular}

\section{GEOTHERMAL DATA SUMMARY SHEET}

rotaA popuLarton: $11,199,385$ TOTat arga: 267,339 se. MI.

GEOTHERMAL OVERVIEW

Parts of five physiographic provinces cover Texas; three of arts of tive physiograp gecthermal potential: the trans-
these have significant geother Pecos region (or Basin and Range Provincel consists of encompass as many as $47.000 \mathrm{sq}$. mi. in central Texas. and
the Coastal Province which contains a geopressured area.

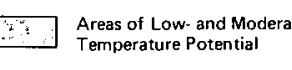

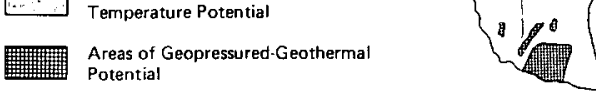

\begin{tabular}{|c|c|}
\hline GEOTHERMAL TEAM & \\
\hline COMMERRC IALIZIZAT ION PLANNING: & None \\
\hline OPERATIONS, RESERRCH（GEOPRESSURED RESOURCE): & $\begin{array}{l}\text { Myron Dor fman (University of Texas center for } \\
\text { Energy studides) }\end{array}$ \\
\hline RESOURCE ASSESSMENT: & C. D. Henry (University of Texas (Austin)) \\
\hline ENERGY AND NATURAL RESOOUCE ADVISORY COUNCIL: & E. Vetter, Executive Director \\
\hline ANALYYSSIS AND DEVELOOPMEN DVVYISTON: & Milton Hoilloway, Di rector \\
\hline DEPARTMENT OF WATER AND NATURAL RESOURCES: & Harvey dayis, Executive director \\
\hline UNIVERSITY OF TEXAS (EL PASO): & Dx. Robert Roy (Dept. of Geological Sciences) \\
\hline UNIVERSTTY OF TEXAS (AUSPTN): & Dr. R. A.' Motrin (Bureau of Economic Geology \\
\hline
\end{tabular}

LEGILLATVE CONTACTS

\begin{tabular}{|c|c|c|}
\hline SENATORS & $\begin{array}{l}\text { John Tower (R) } \\
\text { L1oya Bentsen (D) }\end{array}$ & GOVERNOR Filliam P. Clements, Jr. (R) \\
\hline \multicolumn{3}{|c|}{ CONGRESSMEN (DIST.) } \\
\hline & 1 - Sam B. на11, Jr. (D) & 13 - Jack Hightower (D) \\
\hline & 2 - Charles wilson (D) & $\begin{array}{l}\text { 14 - william N. Patman (D) } \\
15 \text { - E. de la Garza }(D)\end{array}$ \\
\hline & $\frac{3 \text { - James M. Collins (R) }}{4 \text { - Ralph M. Hal1 (D) }}$ & $\frac{15:- \text { E. de la Garza (D) }}{16 \mid \text { - Richard C. White (D) }}$ \\
\hline & 5 -James A. Mattox (D) & 17 - charles w. Stenholm (D) \\
\hline & 6- Phil Granu (D) & 18 - Mickey Leland (D) \\
\hline & $7-$ Bill Archer (R) & 19 - Kent Hance (D) \\
\hline & 8 - Jack Fields (R) & $201-$ Henry B. Gonzalez (D) \\
\hline & 9 - Jack Brooks (D) & $21_{\text {[ }}$ - Tom Loeffler $(R)$ \\
\hline & 10 - J. J. Pick1e (D) & \begin{tabular}{|l|l|l|}
22 & - Ron Paul (R)
\end{tabular} \\
\hline & 11 - Marvin Leath (D) & 23 - Abraham Kazen, Jr. (D) \\
\hline & $12-$ Jim Wright $(D)$ & $24[-$ Martin Frost $(D)$ \\
\hline
\end{tabular}



III. STATE FUEL PRODUCTION (1973) $(C-6)$

Type Number Units Btu

Coal mines

Natural gas (liq.)

Natural gas wells

Crude oil wells

$\begin{array}{rrrr}3 & 6,944 \text { thousand tons } & 91.7 \\ - & 314,429 \text { thousand bbl } & 1,268.0 \\ 23,80 \overline{5} & 8,513,850 \text { milition cu. ft. } & 9,305.6 \\ 159,090 & 1,294,671 \text { thousand bbl } & 7,509.1\end{array}$

IV. $\quad$ GEOLOGY

Texas is covered by five physiographic provinces some of which, at least in parts, are considered to have considerable geothermal potential.

The Trans-Pecos region of the state displays rifts and faults associated with the Rio Grande and the Basin and Range provinces, respectively. This area consists of linear series of sediment filled basins having measured heat flows of 1 to $3.1 \mathrm{HFU}$ and gradients of 1.6 to $3.8^{\circ} \mathrm{F} / 100 \mathrm{ft}$. Geochemical estimates of subsurface temperatures range from 140 to $320^{\circ} \mathrm{F}$. These hot waters are considered to result from fault-controlled circulation of ground waters to depths of 2000 to $7000 \mathrm{ft}$.

In central Texas the Balcones and associated fault zones extend approximately southwestward from Fannin county in the north through the Austin and San Antonio areas and curve to Kinney county at the Mexican border. Gradients range from 1.3 to $2.5^{\circ} \mathrm{F} /$ $100 \mathrm{ft}$. Wells in the area produce water in excess of $120^{\circ} \mathrm{F}$ from depths of about $3500 \mathrm{ft}$. The hot waters from the Balcones Fault come from Cretaceous aquifers, primarily, the Trinity Sandstone of the Edwards Formation. The extent of the aquifers is estimated to be as large as $60,000 \mathrm{sq}$. $\mathrm{mi}$.

The Gulf Coast area consists of many deep sedimentary filled aquifers, some of which contain geopressured fluids. Average temperatures are in excess of $270^{\circ} \mathrm{F}$. Thermal gradients range from 1.1 to over $5^{\circ} \mathrm{F} / 100 \mathrm{ft}$.

V. $\quad$ RESOURCE DATA

There are no confirmed reservoirs (Nov 1979) in Texas and no state or federal lands have been leased for geothermal development.

VI. GEOTHERMAL ACTIVITY

The University of Texas has conducted geochemical studies in the Trans-Pecos area and has made measurements of heat flow, thermal gradient, and electrical resistivity. 
In the central Texas belt the university has defined areas considered to have optimum geothermal potential.

DOE and General Crude Oil Company shared the cost of a $16,500 \mathrm{ft}$. geopressured well drilled in Brazoria county on the Gulf coast. Temperature at depth was over $300^{\circ} \mathrm{F}$. Tests made at $14,700 \mathrm{ft}$. in 1979 produced 2,500 barrels of hot saline water at 4,500 psi.

DOE (PON) and Texas Energy Development Fund moneys provided for a test well for a hospital in Marlin, Falls County, Texas. Bottom hole temperature (at $3885 \mathrm{ft.}$ ) was $140^{\circ} \mathrm{F}$. Artesian pressure produced $152^{\circ} \mathrm{F}$ water at the surface.

Another DOE (PON) funded test well is being drilled (Nov 1979) in Corsicana, Navarro County, Texas for the Navarro Junior College. At $2300 \mathrm{ft}$. the measured temperature was $120^{\circ} \mathrm{F}$.

VII. LEGAL ACTIVITIES

A Geothermal Energy Resources Act (1975) defined the resource and authorized the Railroad Commission to regulate the exploration, development, and production of geothermal energy and associated resources in public and private land. Legislation in 1979 provided that geopressured geothermal resources be treated and produced as mineral resources, and expanded the duties of the Railroad Commission to include responsibility for control and disposition of waste and the issuing of permits for waste discharge.

VIII. CONTACTS

1. State Geothermal Team:

a. Operations Research (geopressured resource), Myron Dorfman (University of Texas Center for Energy Studies);

b. Resource Assessment, C. D. Henry (University of Texas (Austin)).

2. Energy and Natural Resource Advisory Council, E. Vetter, Executive Director.

3. Analysis and Development Division, Milton Holloway, Director.

4. Department of Water and Natural Resources, Harvey Davis, Executive Director. 
5. University of Texas (El Paso), Dr. Robert Roy (Dept. of Geological Sciences).

6. University of Texas (Austin), Dr. R. A. Motrin (Bureau of Economic Geology).

REFERENCES AND LIST OF SIGNIFICANT REPORTS

(1) "Texas Hydrothermal Commercialization Baseline," EG\&G Idaho, Inc., Nov 1979.

COMMON REFERENCES

$(C-4),(C-6)$, and $(C-7)$. 
State Geothermal Fact sheet

UTAH

I. DEMOGRAPHIC INFORMATION (1977) (C-4)

TOTAL STATE

Population: 1,271,000 Area: $84,916 \mathrm{sq} \cdot \mathrm{mi}$. Density: 15 per sq. mi. GEOTHERMAL RESOURCE AREA

Population: 1,059,273 Area: $82,096 \mathrm{sq}$. mi. Density: 13 per sq. mi.

II. ENERGY CONSUMPTION* (1975) (C-7)

\begin{tabular}{|c|c|c|c|c|c|}
\hline & $\begin{array}{l}\text { OIL } \\
\text { (million } \\
\text { bbl) }\end{array}$ & $\begin{array}{l}\text { LPG } \\
\text { (million } \\
\text { gal.) }\end{array}$ & $\begin{array}{c}\text { GAS } \\
\text { (trillion } \\
\text { cu.ft.) }\end{array}$ & $\begin{array}{l}\text { COAL } \\
\text { (million } \\
\text { tons) }\end{array}$ & $\begin{array}{l}\text { ELECTRICITY } \\
\text { PURCHASED } \\
\text { (billion kWh) }\end{array}$ \\
\hline $\begin{array}{l}\text { GROSS } \\
\text { Residential } \\
\text { Commerical } \\
\text { Industrial }\end{array}$ & $\begin{array}{r}31 \\
1 \\
3 \\
7\end{array}$ & $\begin{array}{r}49 \\
25 \\
3 \\
21\end{array}$ & $\begin{array}{r}126 \\
60 \\
6 \\
58\end{array}$ & $\begin{array}{l}5 \\
0 \\
0 \\
0.5\end{array}$ & $\begin{array}{l}8 \\
3 \\
3 \\
2\end{array}$ \\
\hline \multicolumn{6}{|c|}{ Trillion Btu } \\
\hline $\begin{array}{l}\text { GROSS } \\
\begin{array}{l}\text { Residential } \\
\text { Commercial } \\
\text { Industrial }\end{array}\end{array}$ & $\begin{array}{r}171.3 \\
4.0 \\
16.6 \\
39.6\end{array}$ & $\begin{array}{l}4.7 \\
2.4 \\
0.3 \\
2.0\end{array}$ & $\begin{array}{r}130.4 \\
61.7 \\
6.3 \\
59.4\end{array}$ & $\begin{array}{r}116.1 \\
1.6 \\
0.9 \\
13.2\end{array}$ & $\begin{array}{r}25.9 \\
8.6 \\
9.3 \\
8.0\end{array}$ \\
\hline Percentages & 41 & 1 & 31 & 27 & \\
\hline
\end{tabular}

鼻

\footnotetext{
*Excluding nuclear and hydro electricity, coking coal and petroleum coke, and other petroleum products not used as fuels.
} 
III. STATE FUEL PRODUCTION (1973) $(\mathrm{C}-6)$

$\begin{array}{ccc}\text { Type Number Units } & \text { Trilion } \\ \text { Btu }\end{array}$

Coal mines

Natural gas (liq.)

Natural gas wells

Crude oil wells

44
-
158
989

\author{
7,984 thousand tons \\ 2,432 thousand bbI \\ 42,715 million cu. ft. \\ 32,656 thousand bbl
}

203.1

9.8

46.7

189.4

IV. GEOLOGY

The Basin and Range physiographic province occurs in the western part of Utah. This province is characterized by northwardtrending mountain blocks separated by flat valleys filled with unconsolidated alluvial debris to depths of several thousands of feet. The Basin and Range is still tectonically active as indicated by recent fault scarps, young volcanic rocks, and observed seismic activity.

The Colorado Plateau, in the central, eastern, and southern part of the state, is an area of flat-laying sedimentary rocks and several rugged mountain ranges that are cored by laccolithic intrusions. This area is mostly inactive geologically.

In the northeastern part of the state, the Middle Rocky Mountains province contains folded and faulted sedimentary, intrusive, extrusive, and metamorphic rocks. In some portions of the province, seismic evidence of tectonic activity has been identified.

The transition zones between these provinces contain hydrothermally important features. Hydrothermal areas, such as Roosevelt Hot springs, occur in west central and southwestern Utah. To the north many warm springs are found in fault zones.

V.

RESOURCE DATA

One confirmed water-dominated hydrothermal reservoir occurs at the Roosevelt Hot Springs KGRA. About 50\% of the wells drilled (1974) are considered to be useful to industry. Water temperatures are about $500^{\circ} \mathrm{F}$ at depths from about $1,000 \mathrm{ft}$. to more than $4,500 \mathrm{ft}$.

Two other KGRAs are considered to be excellent prospects for high temperature resources: Cove Fort/Sulphurdale and Thermo. Industrial drillers claim to have located seven significant spots in the southwestern counties of Millard, Beaver, and Iron. 
Many prospects for space heating are considered to exist in Utah. A large number of warm springs and water wells are found mainly along the transition of the Basin and Range province with the Colorado Plateau in the south and the Rocky Mountains in the north.

\section{GEOTHERMAL ACTIVITY}

Current use: $\quad$ From the 19 th century geothermal springs have been used for spas and greenhouses. The IDS church in salt Lake City uses a ground-water fed heat pump for space conditioning of an office building.

Studies :

1. The city of Monroe is participating with DOE (PON) in a program for space heating several public buildings. The University of Utah (Earth Science Laboratory) is coordinating (for DOE) contractor assessment of geothermal resources in Utah as well as in other western states.

2. Time Phase Project, Site Specific Development Plans, and Area Development Plans continue to be prepared by the state in cooperation with DOE.

3. A preliminary study for geothermal applications at Hill Air Force Base was completed in 1978 .

VII. LEGAL ACTIVITIES

Current law assigns responsibility of overseeing geothermal development to the Division of Water Rights. Water appropriation laws have been used to define rules and regulations for geothermal exploration and development.

Legislation intended to clarify and amplify state policy concerning geothermal energy was submitted during 1979. Some of the items included were the definition of a resource, municipal powers, and the relationship between the doctrine of appropriation and geothermal resources. A House amendment, precluding implementation of the new law until all pending geothermal water well applications were processed and approved, caused the bill not to be passed. 
VIII. CONTRACTS

1. State Geothermal Team:

a. Operations Research, Stanley Green, Team Leader;

b. Resource Assessment, Don T. McMillan, Project Manager.

2. Department of Natural Resources, Gordon Harmstron, Executive Director.

3. Division of Water Rights, Dee C. Hanse, State Engineer.

4. Utah Geological and Mineral Survey, Donald T. McMillan, Director.

5. State Planning Coordinator's Office, Kent Briggs, Coordinator.

6. Utah Energy Office, Reed Searle, Staff Director.

7. Department of Social Services, Anthony W. Mitchell, Executive Director.

8. Energy Conservation and Development Council, Moroni Jensen, Chairman.

REFERENCES AND LIST OF SIGNIFICANT REPORTS

(1) "Utah Hydrothermal Commercialization Baseline," EG\&G Idaho, Inc., Jun 1979.

(2) David V. McClain, "Geothermal Energy in Idaho: Site Data Base and Development Status," Geo-Heat Utilization Center, Klamath Falls, OR, Jul 1979.

\section{COMMON REFERENCES}

$(C-4),(C-6)$, and $(C-7)$. 


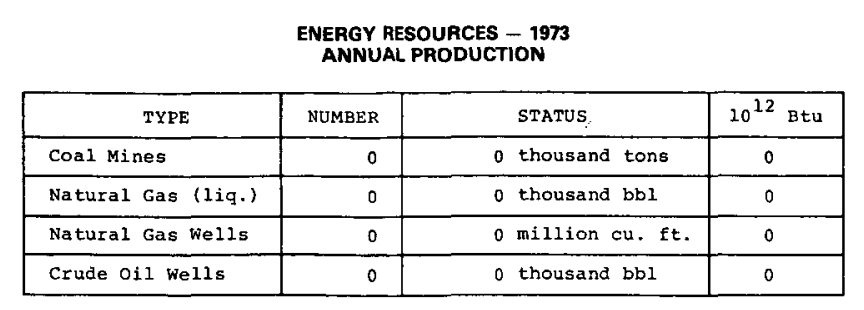

ENERAY USE - 1976 110" BTUI

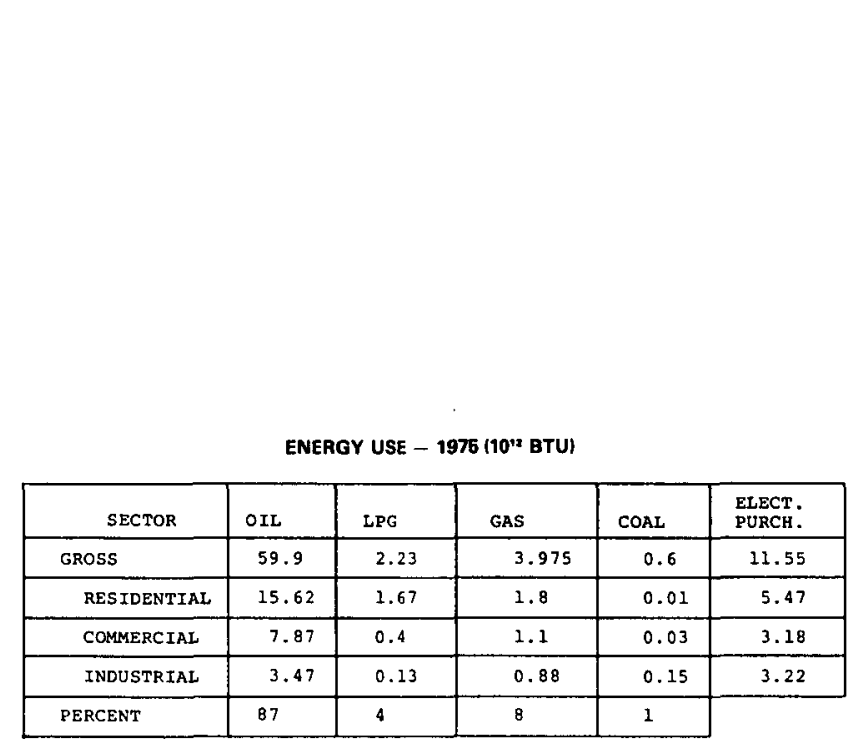

cots

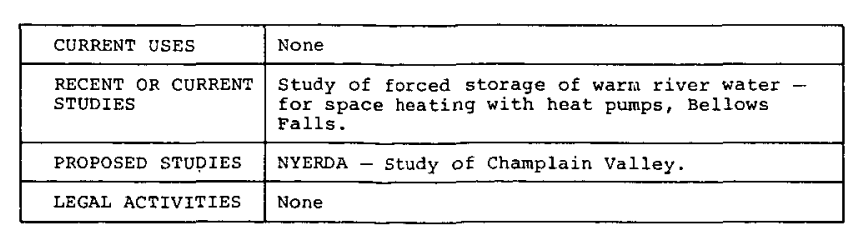

VERMONT
GEOTHERMAL DATA SUMMARY SHEET

PovULATTON: 444,732 TOTAL AREA: 9, 267 50. MI.

POPULATION DENSITY: 48 PERBONS/SQ. MI.

GEOTHERMAL OVERVIEW

The western edge of the state shares a deep seedimentary basin, the Champlain Valley, with New York State. Warm
springs in this area may represent a hydrothermal resource.

- Hot Soring

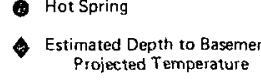

IBA Interior Basin Aquiter

CPA Cossti Pain Aauiterer

IMC Igneous andor Meteamorphic Complex

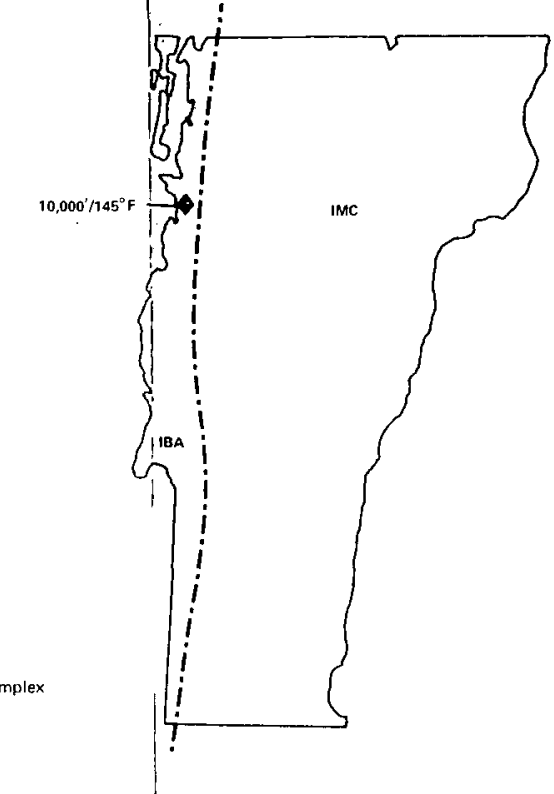

PaimaRY CONTACTS
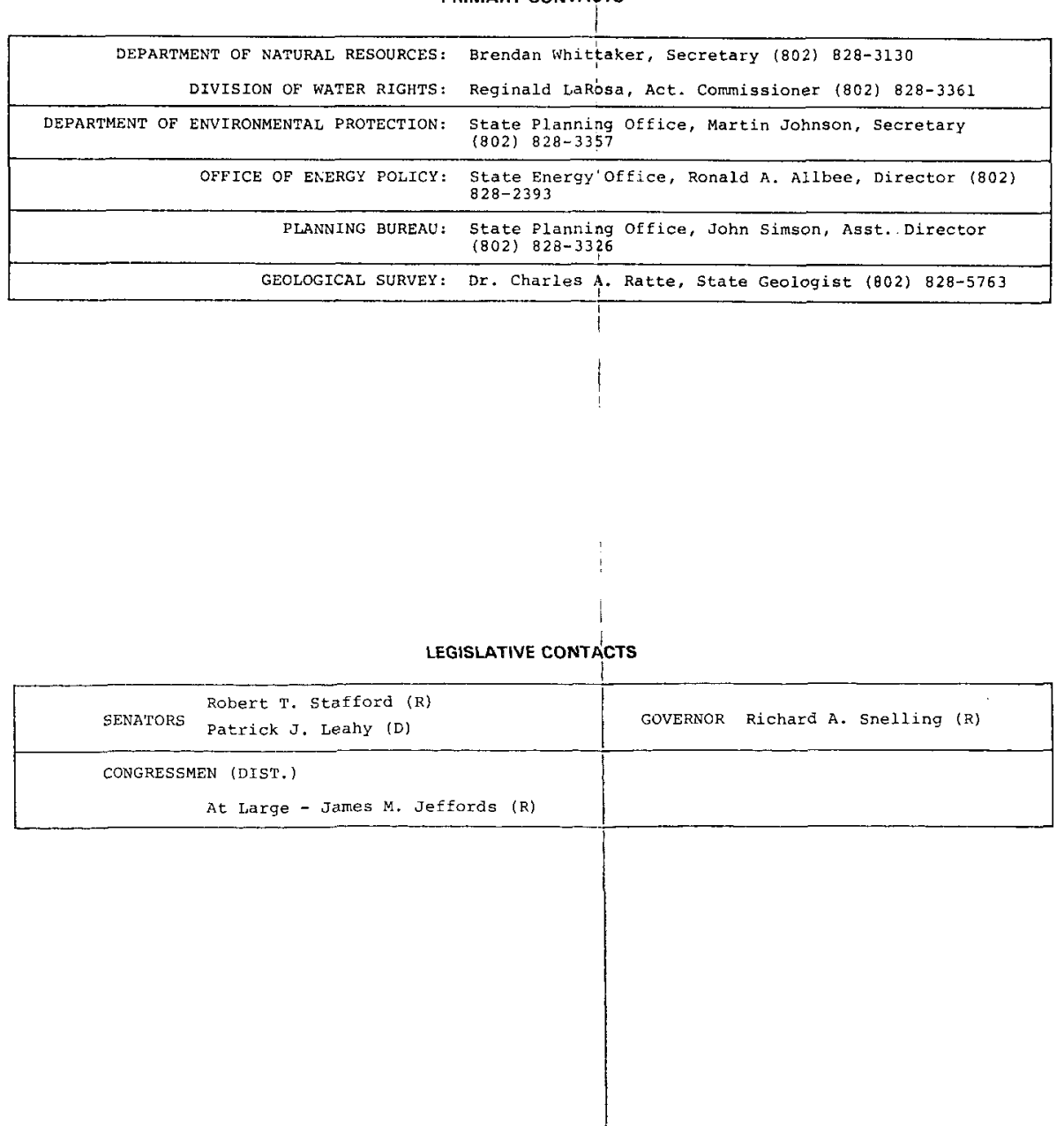
State Geothermal Fact sheet

VERMONT

I. DEMOGRAPHIC INFORMATION (1970) (C-4)

TOTAL STATE

Population: 444,732 Area: 9,267 sq. mi. Density: 48 per sq. mi. GEOTHERMAL RESOURCE AREA

Population:

Area :

sq. mi.

Density:

per sq. mi.

II. ENERGY CONSUMPTION* (1975) (C-7)

OIL
(million
bbl)

LPG (million
Gils
(trillion
cu.ft.) gal.)

11

Residential

Commerical

35

25

Industrial

2
COAL
(million
tons)

ELECTRICITY

PURCHASED

(billion kWh)

$$
\begin{aligned}
& 0.02 \\
& 0.00 \\
& 0.00 \\
& 0.00
\end{aligned}
$$

3
1
1
1

Trillion Btu

\begin{abstract}
GROSS
Residential

Commercial

Industrial
\end{abstract}

Percentages

$\begin{array}{ll}2.23 & 3.975 \\ 1.67 & 1.8 \\ 0.4 & 1.1 \\ 0.13 & 0.88\end{array}$

4
13

8

$$
\begin{array}{r}
59.9 \\
15.62 \\
7.87 \\
3.47
\end{array}
$$

87

$$
\begin{aligned}
& 0.6 \\
& 0.01 \\
& 0.03 \\
& 0.15
\end{aligned}
$$

$$
\begin{array}{r}
11.55 \\
5.47 \\
3.18 \\
3.22
\end{array}
$$

1

*Excluding nuclear and hydro electricity, coking coal and petroleum coke, and other petroleum products not used as fuels. 
III. STATE FUEL PRODUCTION (1973) (C-6)

$\begin{array}{ccc}\text { Type Numbers Units } & \text { Trillion } \\ \text { Btu }\end{array}$

Coal mines

Natural gas (liq.)

Natural gas wells

Crude oil wells
0
0 thousand tons 0

0 thousand bbl 0

0 million cu. ft. 0

0 thousand bbl 0

\section{GEOLOGY}

Vermont is underlain by rocks of Precambrian and Paleozoic age. Throughout most of the state these rocks have been metamorphosed and intruded by ignecus bodies during the Paleozoic orogenies. However, along the western border of the state the Champlain Valley is underlain by a thick sequence of sedimentary rocks (greater than 10,000 ft. deep). This area is highly faulted and fault controlled warm springs occur in several areas.

Large amounts of water flow from surface springs, but the temperatures are low. Little is known about water availability at depth or subsurface temperatures. However, the Champlain Valley is genetically, structurally, and magmatically similar to the area near Montreal, Canada, where the highest thermal gradient in eastern North America occurs. Therefore, this deep and highly faulted sedimentary basin appears to merit evaluation for geothermal resources.

V. RESOURCE DATA

To be determined.

VI. GEOTHERMAL ACTIVITY

Current studies: Study of forced storage of warm river water for space heating with heat pumps (Bellows Falls) $(\mathrm{C}-6)$.

Proposed studies: NYERDA - study of Champlain Valley.

VII. LEGAL ACTIVITIES

To be determined.

VIII. CONTACTS

1. Department of Natural Resources, Brendan Whittaker, secretary, (802) 828-3130. 
2. Division of Water Rights, Reginald LaRosa, Acting Commissioner, (802) 828-3361.

3. Department of Environmental Protection, state Planning office, Martin Johnson, Secretary, (802) 828-3357.

4. Office of Energy Policy, State Energy Office, Ronald A. Allbee, Director, (802) 828-2393.

5. Planning Bureau, State Planning Office, John Simson, Asst. Director, (802) 828-2393.

6. Geological Survey, Dr. Charles A. Ratte, State Geologist, (802) 828-5763.

REFERENCES AND LIST OF SIGNIFICANT REPORTS

(1) "Geothermal Potential of Bellows Falls, Vermont," JHU/APL QM-79-157-1, Jun 1979.

(2) "Rockingham Town Hall Utilization and Energy Management Study, Bellows Falls, Vermont October 1978," John Sharratt Assoc./BFH \& Assoc.

COMMON REFERENCES

$(C-1),(C-4),(C-6),(C-7),(C-8)$, and $(C-10)$. 

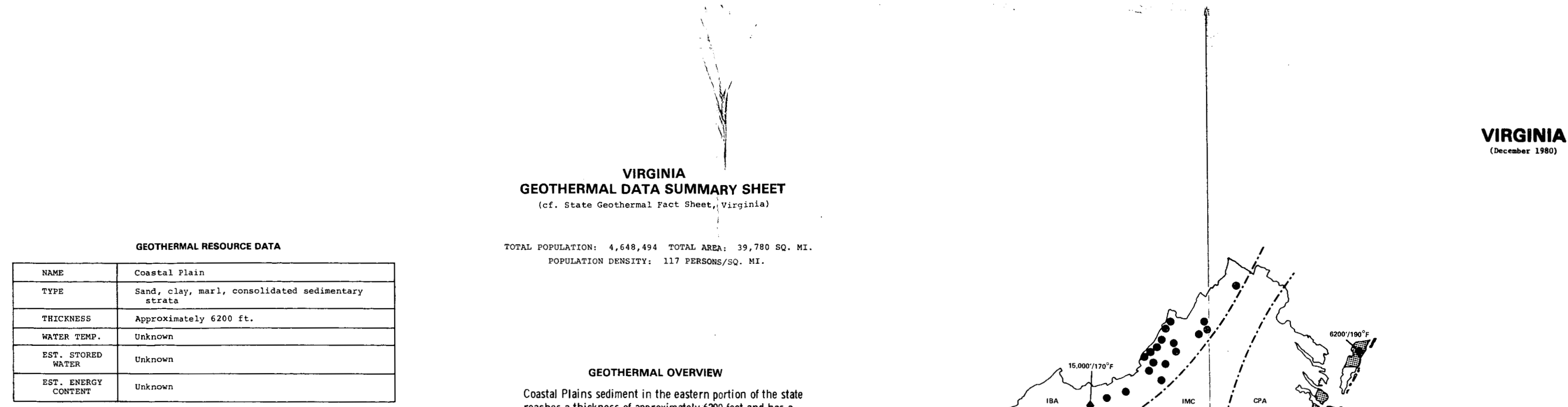

VIRGINIA
GEOTHERMAL DATA SUMMARY SHEET

(1).

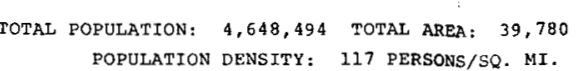

GEOTHERMAL OVERVIEW Coastal Plains sediment in the eastern portion of the state
reaches a thickness of approximately 6200 teet and has a higher than average gradient there. This may be a poten

ENEREV RESOURCES-1993
ANNUAL PROOUCTON

\begin{tabular}{|c|c|c|c|}
\hline TYPE & NUMBER & sratus & $100^{12} \mathrm{Btu}$ \\
\hline Coal Mines & 1,068 & 37,513 thousand tons & 988.8 \\
\hline Natura1 Cas (2iq.) & & 0 thousana bb1 & 0 \\
\hline Natural cas wel1s & 202 & $8,220 \mathrm{mil11}$ ion $\mathrm{cu} \cdot \mathrm{ft}$ & 9.0 \\
\hline Crude oil wells & 4 & 2 thougand bb1 & 0.01 \\
\hline
\end{tabular}
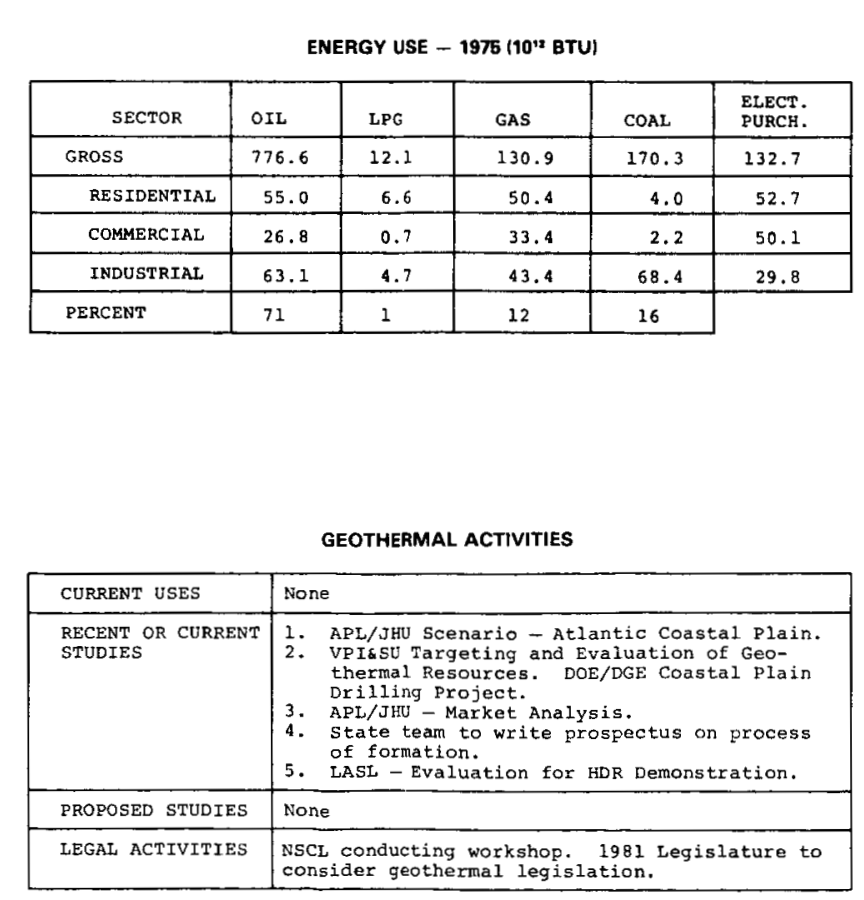
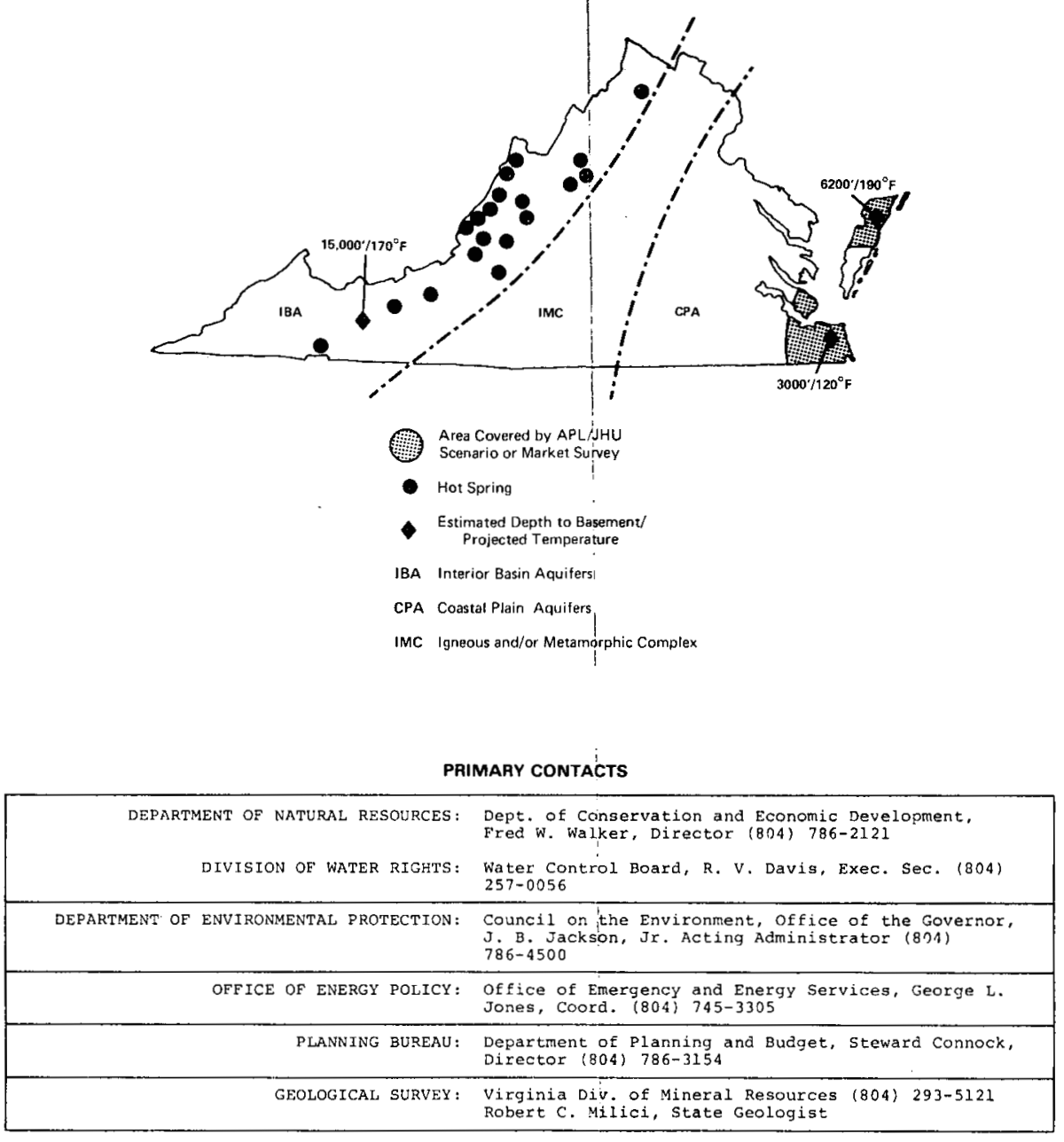

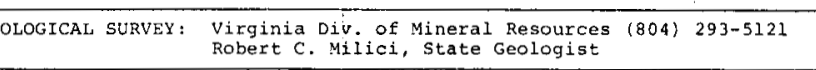

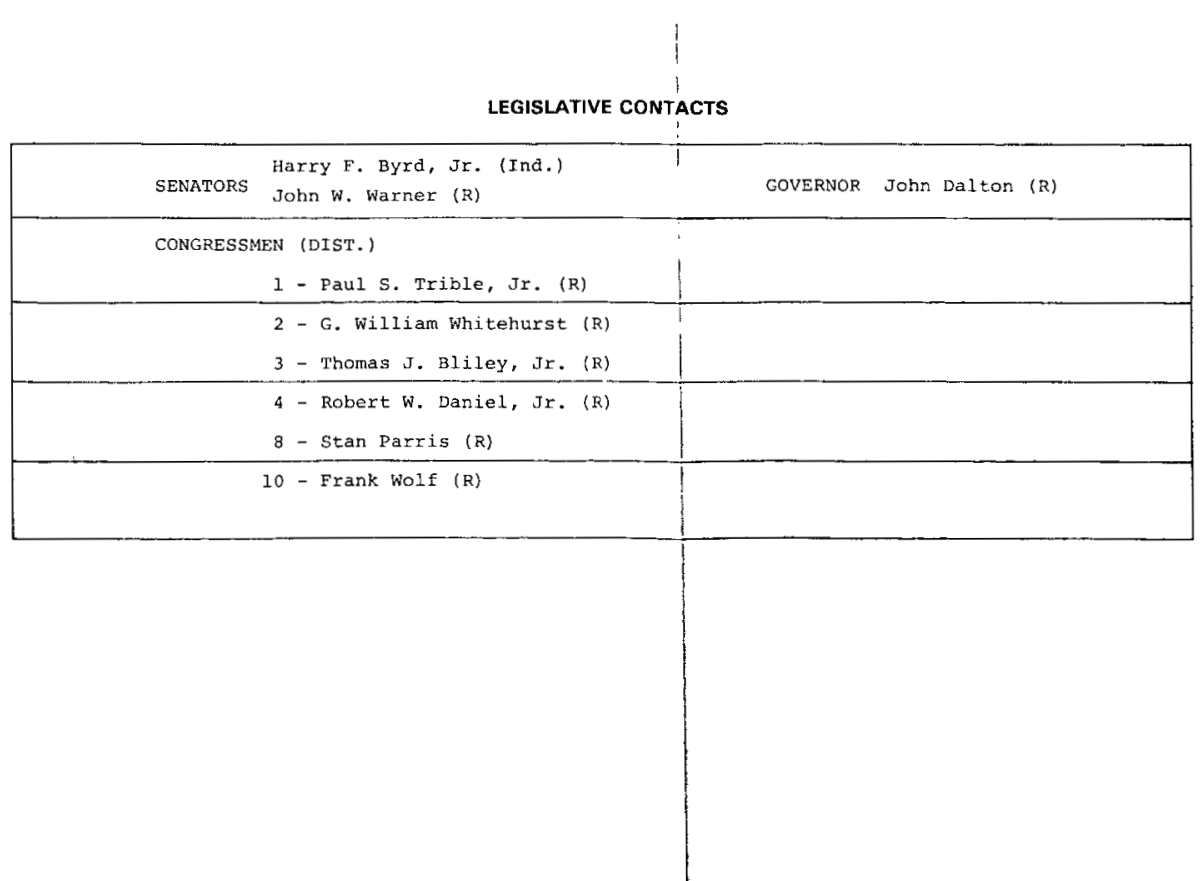


State Geothermal Fact Sheet

VIRGINIA

I. DEMOGRAPHIC INFORMATION (1970) (C-4)

TOTAL STATE

Population: $4,648,494$ Area: $39,780 \mathrm{sq} \cdot \mathrm{mi}$. Density: 117 per sq. $\mathrm{mi}$.

GEOTHERMAL RESOURCE AREA

Population: 1,079,514 Area: $2,438 \mathrm{sq} \cdot \mathrm{mi}$. Density: 443 per sq. mi.

II. ENERGY CONSUMPTION* (1975) (C-7)

\begin{tabular}{|c|c|c|c|c|c|}
\hline & $\begin{array}{l}\text { OIL } \\
(m i l l i o n \\
\text { bbl) }\end{array}$ & $\begin{array}{l}\text { LPG } \\
\text { (milion } \\
\text { gal.) }\end{array}$ & $\begin{array}{l}\text { GAS } \\
\text { (trillion } \\
\text { cu.ft.) }\end{array}$ & $\begin{array}{l}\text { COAL } \\
\text { (milition } \\
\text { tons) }\end{array}$ & $\begin{array}{l}\text { ELECTRICI } \\
\text { PURCHASE } \\
\text { (billion k }\end{array}$ \\
\hline $\begin{array}{l}\text { GROSS } \\
\text { Residential } \\
\text { Commerical } \\
\text { Industrial }\end{array}$ & $\begin{array}{r}137 \\
10 \\
5 \\
10\end{array}$ & $\begin{array}{r}127 \\
69 \\
8 \\
49\end{array}$ & $\begin{array}{r}127 \\
49 \\
32 \\
42\end{array}$ & $\begin{array}{l}7 \\
0.1 \\
0.1 \\
2\end{array}$ & $\begin{array}{r}39 \\
15 \\
15 \\
9\end{array}$ \\
\hline & & Trillion & Btu & & \\
\hline $\begin{array}{l}\text { GROSS } \\
\text { Residential } \\
\text { Commercial } \\
\text { Industrial }\end{array}$ & $\begin{array}{r}776.6 \\
55.0 \\
26.8 \\
63.1\end{array}$ & $\begin{array}{r}12.1 \\
6.6 \\
0.7 \\
4.7\end{array}$ & $\begin{array}{r}130.9 \\
10.4 \\
33.4 \\
43.4\end{array}$ & $\begin{array}{r}170.3 \\
4.0 \\
2.2 \\
68.4\end{array}$ & $\begin{array}{r}132.7 \\
52.7 \\
50.1 \\
29.8\end{array}$ \\
\hline Percentages & 71 & 1 & 12 & 16 & \\
\hline
\end{tabular}

*Excluding nuclear and hydro electricity, coking coal and petroleum coke, and other petroleum products not used as fuels. 
III. STATE FUEL PRODUCTION (1973) $(\mathrm{C}-6)$

Type Numbers Units $\quad$ Trillion

Coal mines

Natural gas (liq.)

Natural gas wells

Crude oil wells

$\begin{array}{rr}1068 & 37,513 \text { thousand tons } \\ - & 0 \text { thousand bbl } \\ 202 & 8,220 \text { million cu. ft. } \\ 4 & 2 \text { thousand bbl }\end{array}$

988.8

0

9.0

0.01

\section{IV. $\quad$ GEOLOGY}

The State of Virginia has at least two regions that are of geothermal interest. The first is the Delmarva Peninsula, the northeast coastal region of the state. The geology of the region consists of a thickening wedge of Mesozoic and Cenozoic sedimentary rocks and unconsolidated strata. These deposits have a maximum thickness of approximately $6200 \mathrm{ft}$. and cover an igneous and metamorphic basement, the surface of which slopes to the east. The principal structural feature is the Salisbury embayment that lies between Newport News, Virginia and Atlantic City, New Jersey. This embayment is fairly prominent in the basement rock, but it loses form in the overlying sedimentary rocks and the unconsolidated deposits.

The second region extends South along the Atlantic sea coast from Norfolk to North Carolina. Basement surface probably occurs at depths of less than $4000 \mathrm{ft}$. in southeast Virginia. Preliminary modeling of negative gravity anomalies in the coastal Plain supports the interpretation of a deep granitic pluton near Norfolk, buried beneath the insulating sedimentary rocks and unconsolidated deposits of the Coastal plain. There are also numerous warm springs $\left(60^{\circ} \mathrm{F}\right.$ to $\left.106^{\circ} \mathrm{F}\right)$ located primarily in a six-country area of west-central Virginia that may offer local resources.

V.

\section{RESOURCE DATA}

Temperatures as high as $130^{\circ} \mathrm{F}$ may be found at depth in the sediments of the southern Virginia Beach region. A number of hot springs exist in western Virginia.

New coastal region data will result from the DOE/DGE drilling program.

VI. GEOTHERMAL ACTIVITY

Geothermal gradient test holes have been completed as part of the DOE/DGE sponsored drilling program. Data are being assessed by VPI\&SU. Drilling sites in the Virginia portion of the Delmarva 
Peninsula and those in the Norfolk/Virginia Beach area are shown on page $\mathrm{VA}-5$.

The Warm Springs, Virginia area has been analyzed specifically by VPI\&SU and by consultant Dr. D. Gysers. The Warm Springs Hotel is considering geothermal space heating (C-15).

LASL in it HDR Program is studying the coastal plain as a potential HDR demonstration site $(\mathrm{C}-8)$.

APL is conducting a study of geothermal applications in coastal regions of the state.

VII. LEGAI ACTIVITIES

1. NCSL is conducting legislative geothermal workshops.

2. The state is organizing a state team to write a geothermal prospectus (5).

\section{CONTACTS}

1. Virginia Office of Emergency and Energy Services, 310 Turner Rd., Richmond, VA 23225, George I. Jones, Coordinator, (804) 745-3305.

2. Division of Mineral Resources, Natural Resources Bldg., P.O. Box 3667, Charlottesville, VA 22901, Robert C. Milici, State Geologist, (804) 293-5121.

3. Virginia Polytechnic Institute and State University, Blacksburg, VA 24061, John K. Costain, Professor of Geophysics, (803) 96l-5096.

4. Virginia Institute of Marine Sciences, Gloucester Point, VA, Thomas A. Barnard, Jr., (804) 642-2111, ext. 186 .

5. Council on the Environment, Office of the Governor, 903 Ninth St. Office Bldg., Richmond, VA 23219, J. B. Jackson, Jr., Acting Administrator (804) 786-4500.

6. State Water Control Board, R. V. Davis, Executive secretary, (804) 257-0056.

\section{REFERENCES AND LIST OF SIGNIFICANT REPORTS}

(1) Division of Mines and Quarries, 1977 Annual Report of Virginia Department of Labor and Industry. 
(2) P. M. Brown, J. A. Miller, and F. M. Swain, "Structural and Stratigraphic Framework, and Spatial Distribution of Permeability of the Atlantic Coastal Plain, North Carolina to New York," U.S.G.C. Professional Paper 796, 1972 .

(3) U. S. Department of the Interior, "Geologic Framework and Petroleum Potential of the Atlantic Coastal Plain and Continental Shelf," Geological Survey Professional Paper 659, 1972 .

(4) G. A. Waring, R. R. Blankenship, and R. Bentall, "Thermal Springs of the United States and Other Countries of the World - A Summary," U. S. Geoloyical Survey Professional Paper 492, 1965.

(5) "Geothermal Policy Report - Issues and Options," Prepared for the Virginia Legislative 1980 Geothermal Policy Review, NCSL, May 1980.

COMMON REFERENCES

$(C-4),(C-6),(C-7),(C-8)$, and $(C-15)$. 


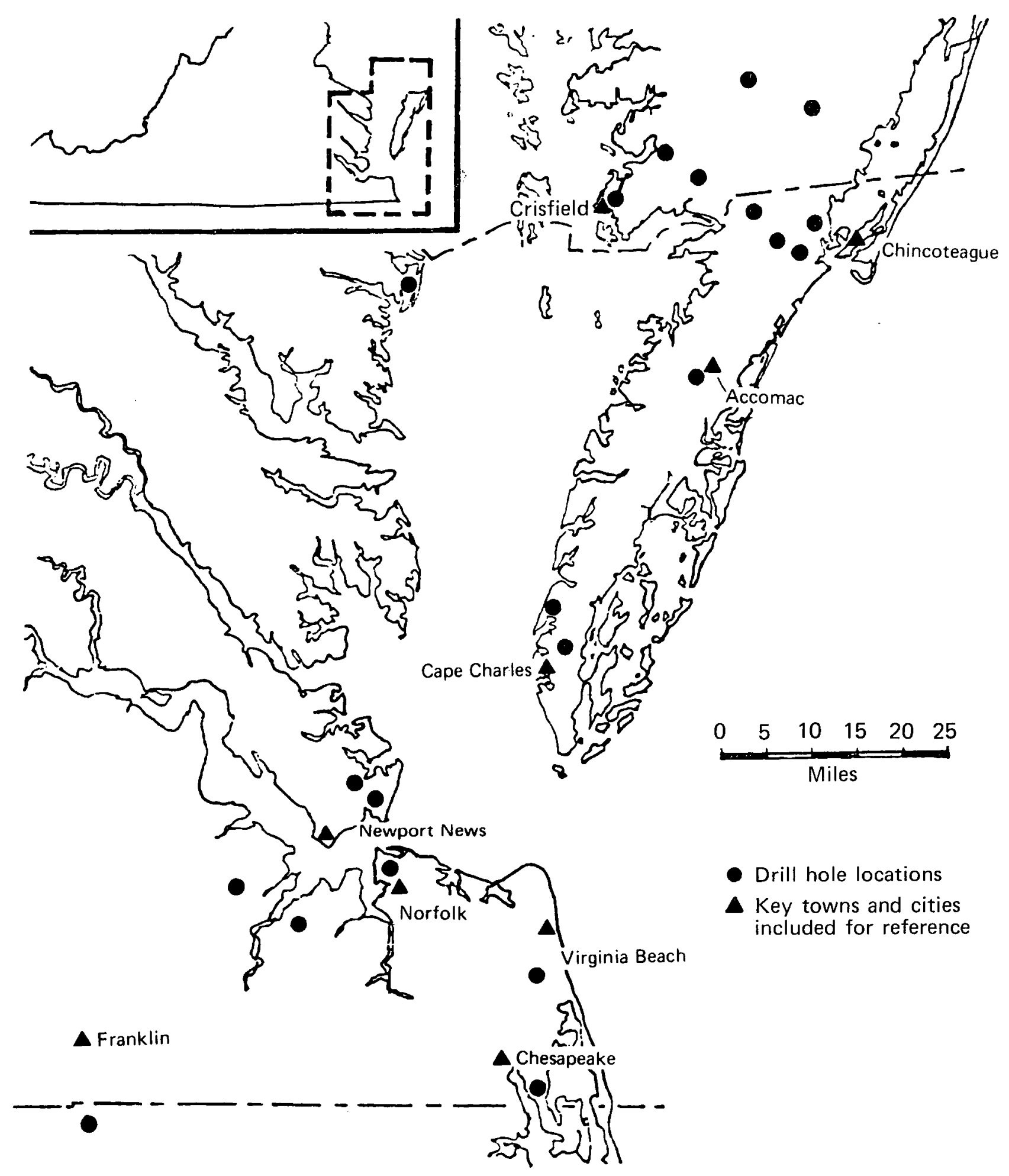

Locations of gradient test holes - Virginia. 
ENERGY RESOURCES - 1975
ANNUAL PROOUCTION

\begin{tabular}{|c|c|c|c|}
\hline$\overline{\text { TYPE }}$ & NUMBER & Status & $10^{12}$ Btu \\
\hline Coal Mines & 3 & 3,270 thousand tons & 63.2 \\
\hline Natural Gas (1iq.) & & 0 thousand $\mathrm{bb} 1$ & 0 \\
\hline Natural Gas we11s & 0 & 0 million cu. $\mathrm{ft}$. & 0 \\
\hline crude of1 we11s & 0 & 0 thousand bbl & - \\
\hline
\end{tabular}

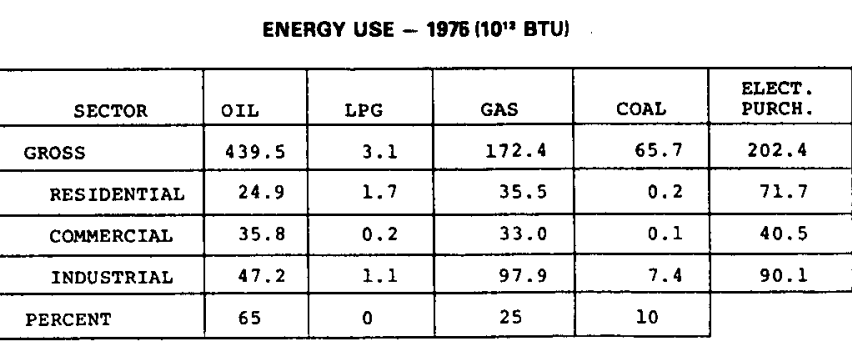

GEOTHERMAL ACTIVITIES

\begin{tabular}{|l|l|}
\hline CURRENT USES & \\
\hline RRCERT OR CURRENT & \\
\hline STUDN IES & \\
\hline PROPOSES STUDIES & \\
\hline LEEAS ACTIUITIES & \\
\hline
\end{tabular}

WASHINGTON RREA: 66,570 SQ. MT.

The principal geologic province in Washington for geotherwhich contains Tertiary to Recent Andesitic strato-volcanoes and basallic valcanic cotters. Three Known GeoIndian Heaven fissure zone area, and Kennedy Hot Springs and three Potential Geothermal Resource Areas

occur in the Cascodes and are of interest since theyyied strong geologic evidence of recent volcanism or thermal activity.

\begin{tabular}{|c|c|}
\hline \multicolumn{2}{|l|}{$\begin{array}{l}\text { DEPRRTMENT OF NATURAL RESOURCES: } \\
\text { DIVISTON OF WATER RICHTS: }\end{array}$} \\
\hline DEPARTMENT OF ENVIROMMENAAL PROTECTT & \\
\hline OFF ICE OF ENERGY POLIT & \\
\hline \multicolumn{2}{|c|}{ PLANNING BUREAU: } \\
\hline \multicolumn{2}{|c|}{ GEOLOGTCAL SURVEY: } \\
\hline \multicolumn{2}{|c|}{ LEGISLATIVE CONTACTS } \\
\hline 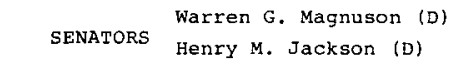 & GoverNOR Dixy Lee Ray (D) \\
\hline 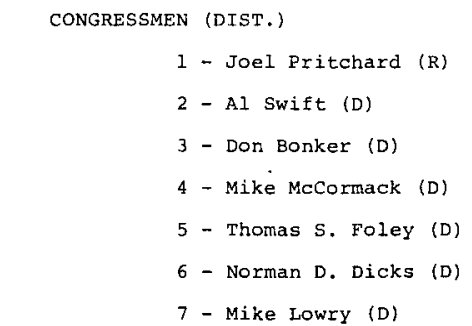 & \\
\hline
\end{tabular}
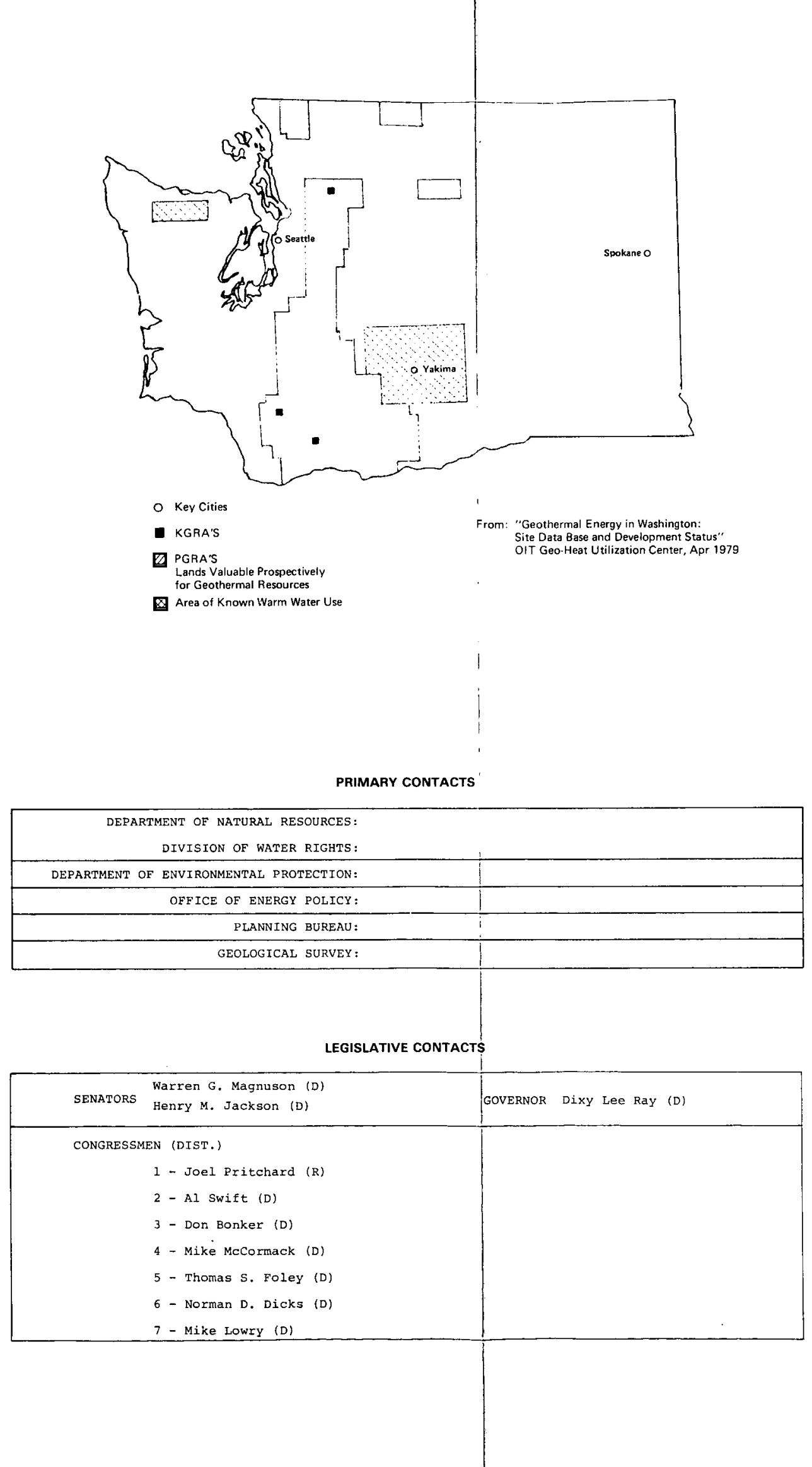
State Geothermal Fact sheet

WASHINGTON

I. DEMOGRAPHIC INFORMATION (1970) (C-4)

TOTAI STATE

Population: 3,409,169 Area: 66,570 sq. mi. Density: 51 per sq. mi.

GEOTHERMAi RESOURCE AREA

Population:

Area :

sq. mi. Density: per sq. mi.

II. ENERGY CONSUMPTION* (1975) (C-7)

$\sum_{i=1}^{i}$

(milizion

LPG

(million

gal.)

GAS
(trillion
cu.ft.)

COAL

(million

80

Residential

Commerical

Industrial

32
18
2
11

167

34

32

!) 5

tons)

ELECTRICITY

PURCHASED

(billion k.Wh)

Trillion Btu

\section{GROSS \\ Residential \\ Commercial \\ Industrial}

Percentages

$\begin{array}{rr}3.1 & 172.4 \\ 1.7 & 35.5 \\ 0.2 & 33.0 \\ 1.1 & 97.9\end{array}$

25

0$$
47.2
$$

4
0
0
0

$$
\begin{array}{r}
65.7 \\
0.2 \\
0.1
\end{array}
$$

$$
\begin{array}{r}
202.4 \\
71.7 \\
40.5 \\
90.1
\end{array}
$$

10

*Excluäing nuclear and hydro electricity, coking coal and petroleum coke, and other petroleum products not used as fuels. 
III. STATE FUEL PRODUCTION (1973) (C-6)

Type Number Units $\quad$ Btu

Coal mines

Natural gas (liq.)

Natural gas wells

Crude oil wells

$\begin{array}{ccc}3 & 3,270 \text { thousand tons } & 63.2 \\ - & 0 \text { thousand bbl } & 0 \\ 0 & 0 \text { million cu. ft. } & 0 \\ 0 & 0 \text { thousand bbl } & 0\end{array}$

IV. GEOLOGY

The principal geologic province in washington for geothermal resource is the north-south trending Cascade Range, which contains Tertiary to Recent Andesitic strato-volcanoes and basaltic volcanic centers. Three KGRA's, Mount St. Helens, Indian Heaven fissure zone area, and Kennedy Hot Springs and three PGRA's, Mount Adams, Mount Rainier, and Mount Baker occur in the Cascades and are of interest since they yield strong geologic evidence of recent volcanism or thermal activity. In addition to the GRA's, two other regions are of interest because they are areas of known warm water use. The city of Yakima which overlies Miocene basalts contains warm springs with chemistries that indicate temperatures of about $100^{\circ} \mathrm{C}$ at depth. In the northern part of the olympic Peninsula, the Olympic and Sol Duc Hot Springs chemistries indicate temperatures of $90^{\circ}$ to $105^{\circ} \mathrm{C}$. This area is underlain by greatly faulted Tertiary sedimentary rocks. A region of anomalously high geothermal gradients underlie the large area of Pleistocene loess deposits in east central Washington.

V. RESOURCE DATA

To be determined.

VI. GEOTHERMAL ACTIVITY

To be determined.

VII. LEGAL ACTIVITIES

To be determined.

VIII. CONTACTS

To be determined. 
THE JOHNS HOPKINS UNIVERSITY

APPLIED PHYSICS LABORATORY

LAuREL, MARYLAND

\section{REFERENCES AND LIST OF SIGNIFICANT REPORTS}

(1) R. Gordon Bloomquist, "Geothermal Energy in Washington: Site Data Base and Development Status," Geo-Heat Utilization Center, Klamath Falls, OR, Apr 1979.

\section{COMMON REFERENCES}

$$
(C-4),(C-6), \text { and }(c-7) \text {. }
$$




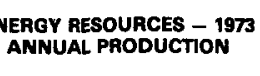

\begin{tabular}{|c|c|c|c|}
\hline TYPE & NUMBER & $\begin{array}{l}\operatorname{sparus} \\
\end{array}$ & $10^{12}$ Btu \\
\hline Coal M1nes & 932 & 125,446 thousand tons & 3,094 \\
\hline Natural Gas (11q.) & & 0 thousand $\mathrm{bb} 1$ & \\
\hline Natural Gas We118 & 21,400 & 208,676 mill1ion cu. ft. & 228.1 \\
\hline Crude O11 he11s & 13,600 & 2,385 thousand bbl & 13. \\
\hline
\end{tabular}

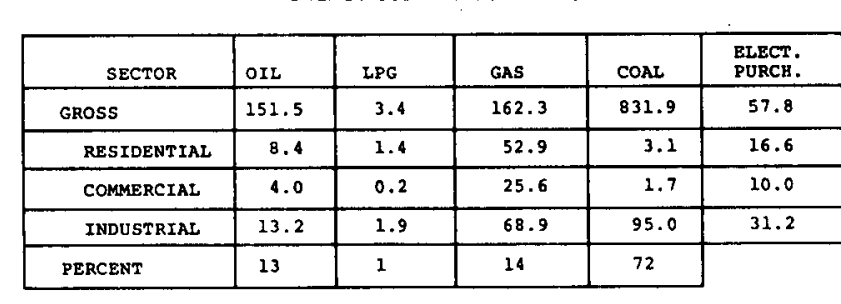

GEOTHERMAL ACTIVTIIES

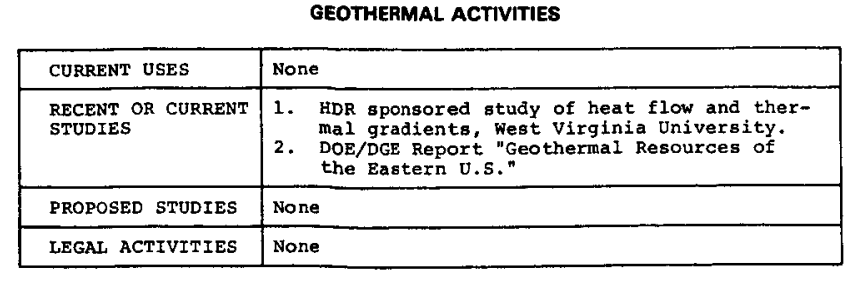

WEST VIRGINIA

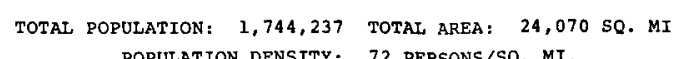

GEOTHERMAL OVERVIEW The deep sedimentary Appalachian Basin runs through the
center of the state, and may represent a hydrothermal center of the state, and may rees
resource with normal gradients.
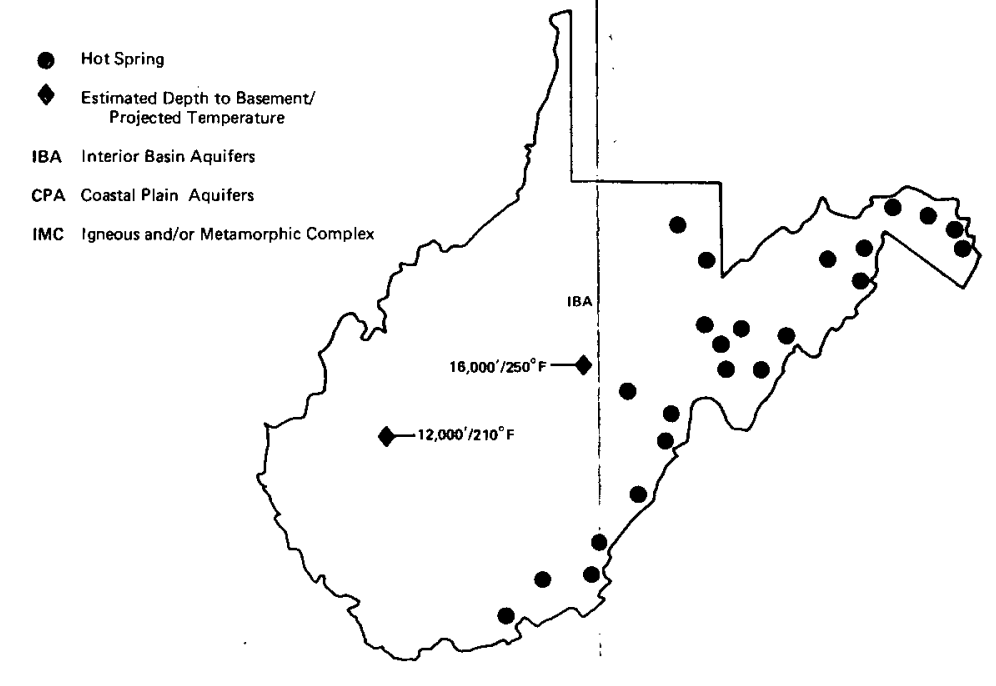

PRIMAAY CONTACTS

J5., Director (304) 398-2754

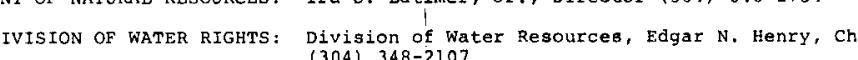

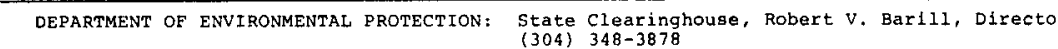

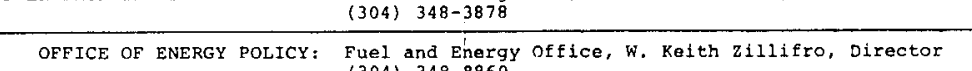
cemere

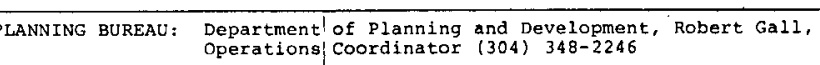

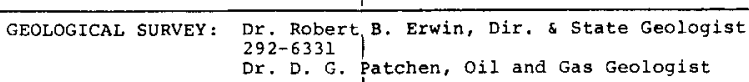

\begin{tabular}{|c|c|}
\hline 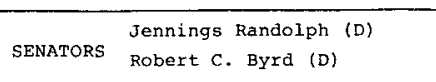 & COVyRROR John D. Rockefél1er 4 th (D) \\
\hline $\begin{array}{l}\text { CONGRESSNEN (DIST.) } \\
1-\text { Robert H. Mol1ohan (D) } \\
2 \text { - cleve Benedict (R) }\end{array}$ & \\
\hline $\begin{array}{l}3 \text { - Mick Staton (R) } \\
4 \text { - Nick J. Raha11 II (D) }\end{array}$ & \\
\hline
\end{tabular}



III. STATE FUEL PRODUCTION (1973) $(\mathrm{C}-6)$

Type Number Units cillion

Coal mines

Natural gas (liq.)

Natural gas wells

Crude oil wells

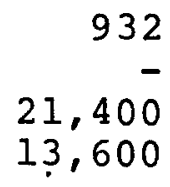

3,094

0

228.1

13.8

IV. GEOLOGY

West Virginia is underlain by sedimentary rocks of Paleozoic age. These sedimentary rocks, which lie in the Appalachian Basin, thicken from 10,000 ft. in the western part of the state to over $20,000 \mathrm{ft}$. in the east. Major structures (faults) have deformed and controlled the deposition of the sediments. One of these, the Rome Trough, coincides with the occurrence of geopressured wells. These rocks are highly indurated at depth, but are prevasively fractured. Thus oil and gas recovery is a function of the secondary permeability. Large quantities of water have been produced from some deep wells although dry holes are more commonly encountered at depth. The deep holes have been drilled predominantly in the Rome Trough Area. Precambrian through Tertiary igneous intrusives and extrusives occur along the eastern border of the state in an area that is now dotted by warm springs.

V. RESOURCE DATA

In the Appalachian Basin geothermal gradients as high as $1.8^{\circ} \mathrm{F} / 100 \mathrm{ft}$. have been reported.

At a depth of $10,000 \mathrm{ft}$. beneath Morgantown or Huntingdon where the gradient is about $1.5^{\circ} \mathrm{F} / 100 \mathrm{ft}$, temperatures of about $200^{\circ} \mathrm{F}$ may occur. Temperatures as high as $106^{\circ} \mathrm{F}$ and flow rates of $1500 \mathrm{gal} / \mathrm{min}$ exist at the surface in the area of the warm springs.

VI. GEOTHERMAL ACTIVITY

1. Study of geothermal gradient and heat flow sponsored by LASL HDR Program, at University of West Virginia (1).

2. Analysis of the state as part of Gruy Federal DOE/DGE Eastern Resource Definition Program (2).

\section{LEGAL ACTIVITIES}

None at present. 
VIII. CONTACTS

1. West Virginia Geological and Economic Survey, P.o. Box 879, Morgantown, WV 26505, Dr. Robert Erwin, Director, (304) 292-6331; Dr. Larry Woodford, Assistant Director; and Dr. D. G. Patchen, Oil and Gas Geologist.

2. Dr. H. H. Ieike, Petroleum Engineer

3. Fuel and Energy office, $1262 \frac{1}{2}$ Greenbriar St., Charleston, WV 25311, W. Keith Zillifro, Director, (304) 348-8860.

4. Department of Natural Resources, Ira S. Latimer, Jr., Director, (304) 348-2754.

5. Division of Water Resources, Edgar N. Henry, Chief, (304) 348-2107.

6. Department of Environmental Protection, state Clearinghouse, Robert V. Barill, Director (304) 348-3878.

7. Department of Planning and Development, Robert Gall, Operations Coordinator, (304) 348-2246.

REFERENCES AND LIST OF SIGNIFICANT REPORTS

(1) Herman H. Rieke III, "Recent Determinations of Geothermal Gradients and Heat Flow Values for Well-sites in West Virginia using an Exact Computation of Methods," University of West Virginia (published in $\mathrm{C}-8$ ).

(2) J. L. Renner and Tracy L. Vaught, Preliminary Definition of the Geothermal Resource Potential of West Virginia, Jan 1979, NVo-1558-8, Gruy Federal, Inc., Arlington, VA.

\section{COMMON REFERENCES}

$(C-4),(C-6),(C-7)$, and $(C-8)$. 


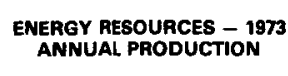

\begin{tabular}{|c|c|c|c|}
\hline TYPE & NCMEER & sraxus & $10^{12} \mathrm{Btu}$ \\
\hline coal Mines & 0 & 0 thousand tons & 0 \\
\hline Natural Gas (11q.) & 0 & 0 thousand bb1 & 0 \\
\hline Naturat Gas wel1s & 0 & 0 million cu. ft. & 0 \\
\hline Crude oil he $11 \mathrm{~s}$ & 0 & 0 thousand $\mathrm{bbl}$ & 0 \\
\hline
\end{tabular}
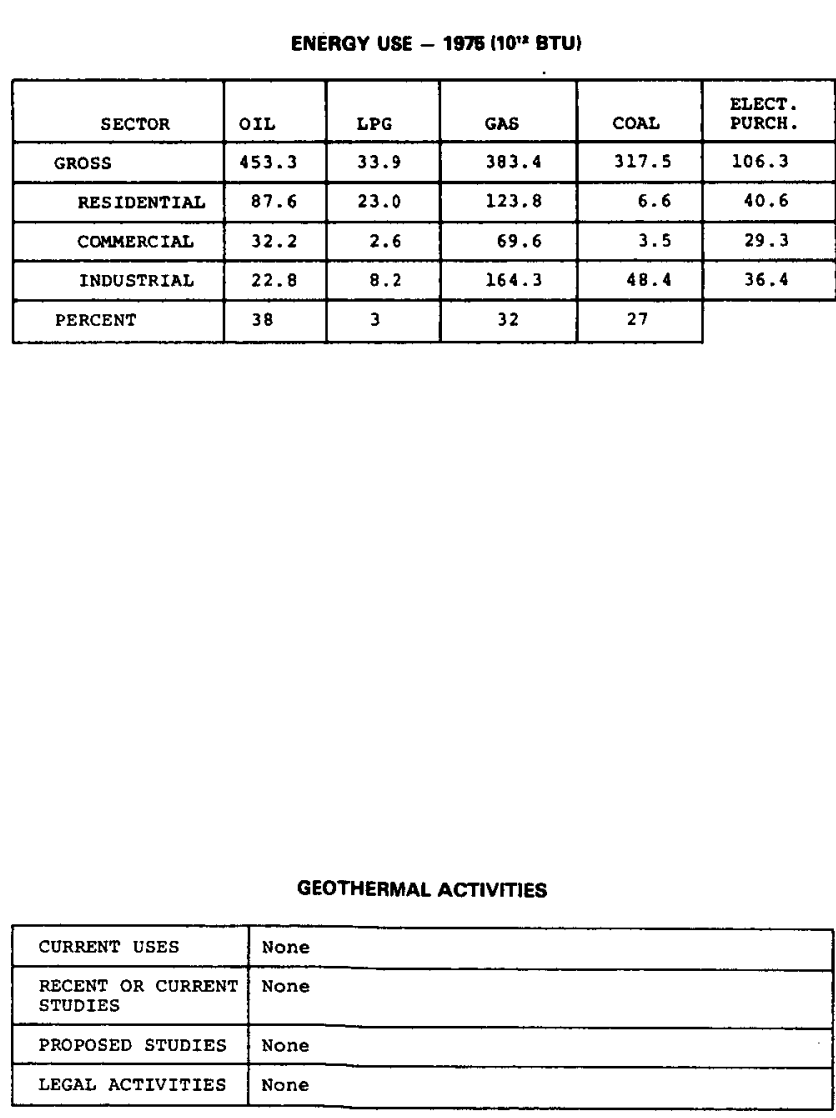

WISCONSIN

DATA SUMMARY SHEET

$$
\text { (cf., state Geothermal Fact sheet, wisconsin) }
$$

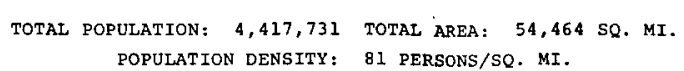

GEOTHERMAL OVERVIEW

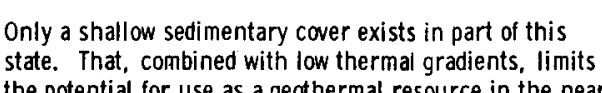
state. That, combined with how thermal gradients, limits
the potential for use as a geothermal resource in the near
future.

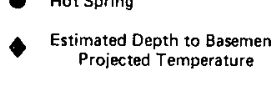

IBA Interior Basin Aquit

CPA Coostal Plain Aquiters

IMC Igreous andior Mearamorphic Conplex

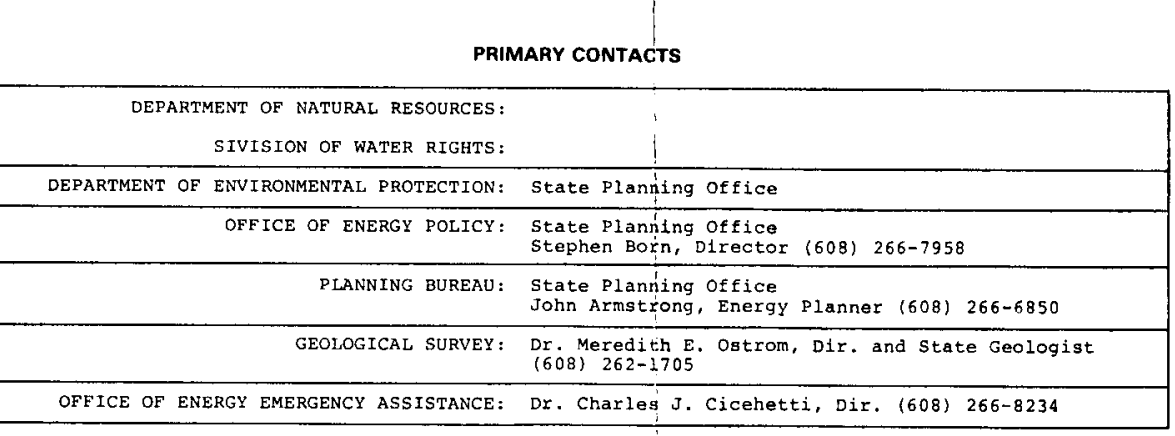

\begin{tabular}{|c|c|c|}
\hline SENATORS & 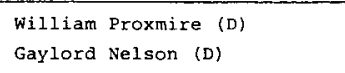 & GOVERNOR Lee Sherman Dreyfus $(\mathbb{R})$ \\
\hline \multicolumn{3}{|c|}{$\begin{array}{l}\text { ConGRESSMEN (DIST.) } \\
1 \text { - Les Aspin (D) }\end{array}$} \\
\hline & $\begin{array}{l}2 \text { - Robert w. Kastenne iex } \\
3-\text { Stoven Gunderson }(R)\end{array}$ & \\
\hline & $\begin{array}{l}4 \text { - Clement J. Zablocki (D) } \\
5 \text { - Henry S. Reuss (D) }\end{array}$ & \\
\hline & $\begin{array}{l}6-\text { Thomas E. Petri (R) } \\
7 \text { - David R. Obey (D) }\end{array}$ & \\
\hline & $\begin{array}{l}8-\text { Tobias Roth (R) } \\
9-\text { Janes Sensenbrenner (R) }\end{array}$ & \\
\hline
\end{tabular}


State Geothermal Fact sheet

WISCONSIN

I. DEMOGRAPHIC INFORMATION (1970) (C-4)

TOTAL STATE

Population: 4,417,731 Area: 54,464 sq. mi. Density: 81 per sq. mi.

GEOTHERMAL RESOURCE AREA

Population:

Area :

sq. mi.

Density:

per sq. mi.

II. ENERGY CONSUMPTION* (1975) (C-7)

\begin{tabular}{|c|c|c|c|c|c|}
\hline & $\begin{array}{l}\text { OIL } \\
\text { (million } \\
\text { bbl) }\end{array}$ & $\begin{array}{l}\text { LPG } \\
\text { (million } \\
\text { gal.) }\end{array}$ & $\begin{array}{c}\text { GAS } \\
\text { (trillion } \\
\text { cu.ft.) }\end{array}$ & $\begin{array}{l}\text { COAL } \\
\text { (million } \\
\text { tons) }\end{array}$ & $\begin{array}{l}\text { ELECTRICITY } \\
\text { PURCHASED } \\
\text { (billion kWh) }\end{array}$ \\
\hline $\begin{array}{l}\text { GROSS } \\
\text { Residential } \\
\text { Commerical } \\
\text { Industrial }\end{array}$ & $\begin{array}{r}83 \\
15 \\
5 \\
4\end{array}$ & $\begin{array}{r}355 \\
240 \\
27 \\
86\end{array}$ & $\begin{array}{r}372 \\
120 \\
67 \\
159\end{array}$ & $\begin{array}{l}14 \\
0.3 \\
0.1 \\
2\end{array}$ & $\begin{array}{r}31 \\
12 \\
9 \\
10\end{array}$ \\
\hline \multicolumn{6}{|c|}{ Trillion Btu } \\
\hline $\begin{array}{l}\text { GROSS } \\
\text { Residential } \\
\text { Commercial } \\
\text { Industrial }\end{array}$ & $\begin{array}{r}453.3 \\
87.6 \\
32.2 \\
22.8\end{array}$ & $\begin{array}{r}33.9 \\
23.0 \\
2.6 \\
8.2\end{array}$ & $\begin{array}{r}383.4 \\
123.8 \\
69.6 \\
164.3\end{array}$ & $\begin{array}{r}317.5 \\
6.6 \\
3.5 \\
48.4\end{array}$ & $\begin{array}{r}106.3 \\
40.6 \\
29.3 \\
36.4\end{array}$ \\
\hline Percentages & 38 & 3 & 32 & 27 & \\
\hline
\end{tabular}

*Excluding nuclear and hydro electricity, coking coal and petroleum coke, and other petroleum products not used as fuels. 
III. STATE FUEL PRODUCTION (1973) (C-6)

Type Number

Coal mines

Natural gas (liq.)

Natural gas wells

Crude oil wells
Units

0 thousand tons

0 thousand bbl

0 million cu. ft.

0 thousand $\mathrm{bbl}$
Trillion

Btu

$$
\begin{aligned}
& 0 \\
& 0 \\
& 0 \\
& 0
\end{aligned}
$$

IV. GEOLOGY

To be supplied.

V. RESOURCE DATA

To be supplied.

VI. GEOTHERMAL ACTIVITY

To be determined.

VII. LEGAL ACTIVITIES

To be determined.

VIII. CONTACTS

1. Office of Energy Policy, State Planning Office, stephen Born, Director, (608) 266-7958.

2. Planning Bureau, State Planning office, John Armstrong, Energy Planner, (608) 266-6850.

3. Geological Survey, Dr. Meredith E. Ostrom, Director and State Geologist, (608) 262-1705.

4. Office of Energy Emergency Assistance, Dr. Charles J. Cicehetti, Director, (608) 266-8234.

REFERENCES AND LIST OF SIGNIFICANT REPORTS

Common references only, see below.

COMMON REFERENCES

$(C-4),(C-6)$, and $(C-7)$. 

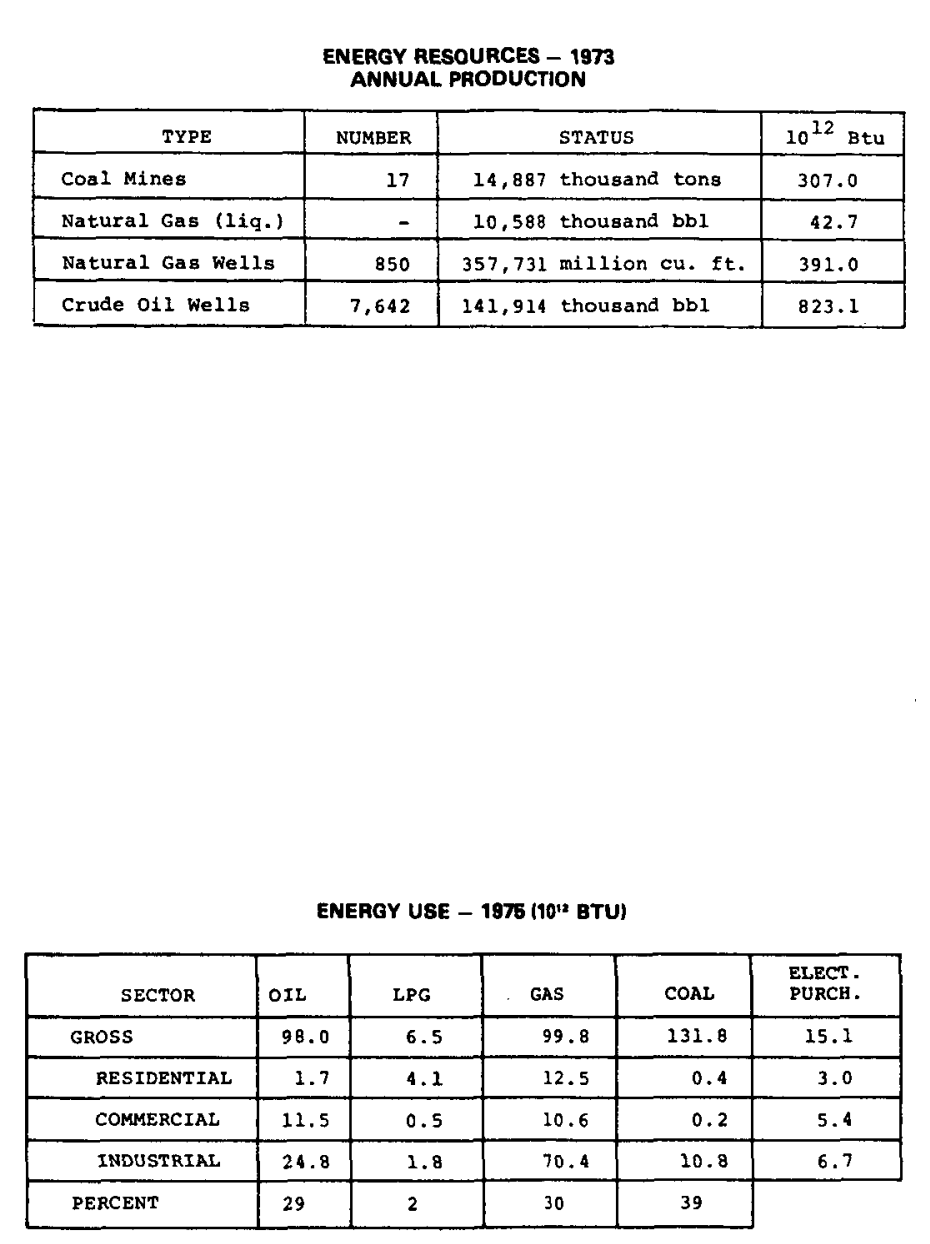

GEOTHERMAL ACTIVITIES

\begin{tabular}{|c|c|}
\hline \multicolumn{2}{|r|}{ GEOTHERMAL ACTIVITIES } \\
\hline CUREENT USES & \\
\hline $\begin{array}{l}\text { RECENT OR CURRENT } \\
\text { STUDIES }\end{array}$ & \\
\hline PROPOSED STUDIES & \\
\hline LEGAL ACTIVITIES & $\begin{array}{l}\text { ceothermal legislation is being drafted for } \\
\text { presentation in } 1980 \text {. }\end{array}$ \\
\hline
\end{tabular}

WYOMING
GEOTHERMAL DATA SUMMARY SHEET (cf., state Geothermal Fact sheet, wyoming)

TOOAL POPDLATTON: 374,000 TOTRA ARRA: 97,914 SQ. MI.

$$
\begin{aligned}
& \text { POPULATION: } 374,000 \text { TOTAL ARRA: } 97,914 \\
& \text { POPULATION DENSITY: } \\
& 3.8 \text { PERSONS/SQ. MI. }
\end{aligned}
$$

GEOTHERMAL OVERVIEW

Wyoming has numerous hot springs which are some of the largest in the world, and hicludos hose at hermoopolis. Recen dita hertical Wyoming indicate the potential for Oil and gas drilling activities have found some waters that appear to be useful for direct applications. Leasing activity has been very limited and very little has been done
in gecthermal legislation.

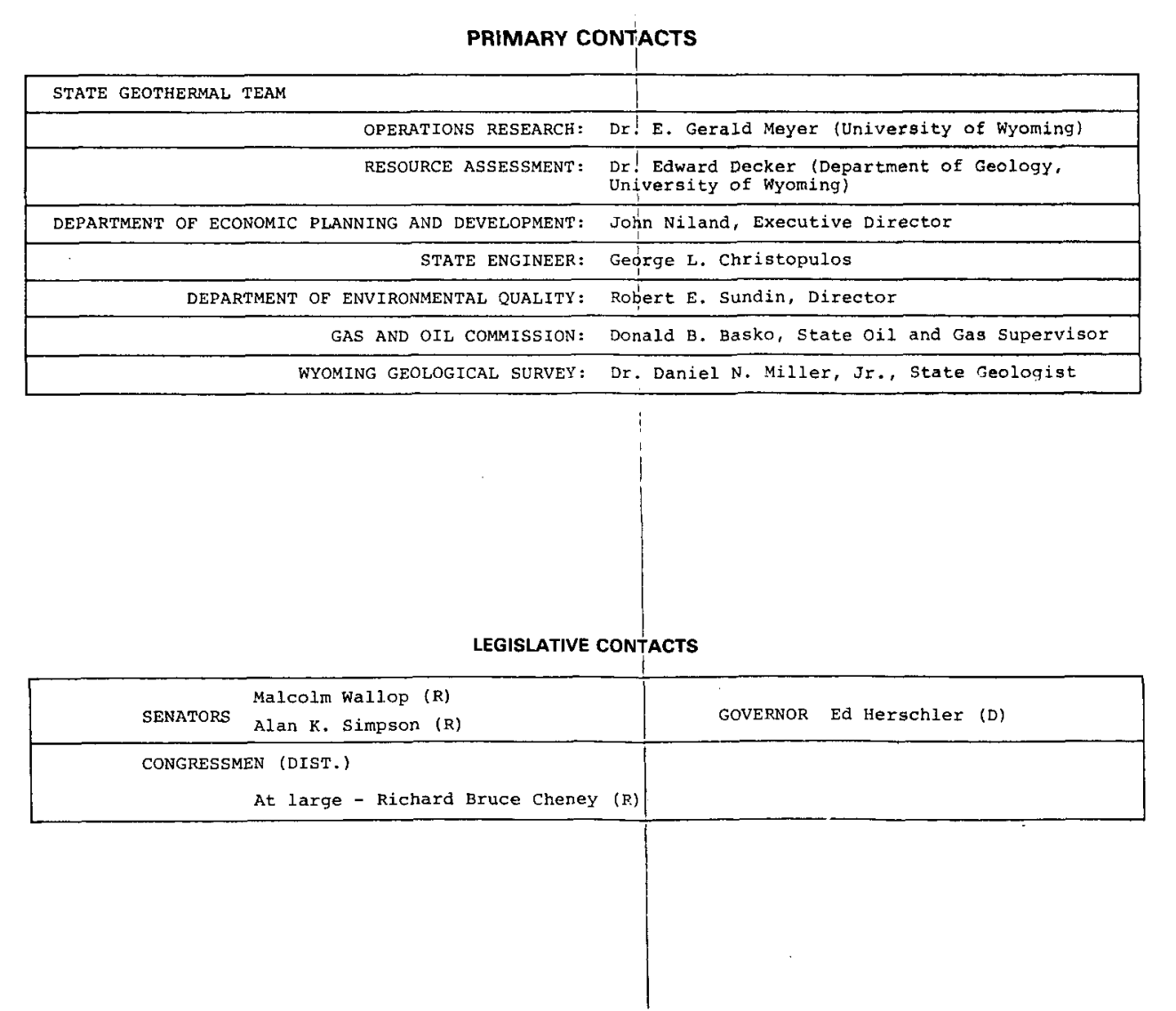


State Geothermal Fact Sheet

WYOMING

I. DEMOGRAPHIC INFORMATION (1977) (C-4)

TOTAL STATE

Population: 374,000 Area: $97,914 \mathrm{sq} \cdot \mathrm{mi}$. Density: 3.8 per sq. mi.

GEOTHERMAL RESOURCE AREA

Population:

II. ENERGY CONSUMPTION*

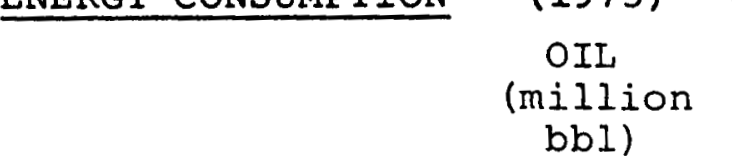

GROSS

Residential

Commerical

Industrial

17

GROSS
Residential
Commercial
Industrial

Percentages
17
0

0
2

4

Area :

sq. mi .

$(\mathrm{C}-7)$

LPG

(million

gal.)

GAS
(trillion
cu.ft.)
97
12
10
68

Trillion Btu

98.0
1.7
11.5
24.8

29

$\begin{array}{ll}6.5 & 99.8 \\ 4.1 & 12.5 \\ 0.5 & 10.6 \\ 1.8 & 70.4\end{array}$

2

30

$$
\begin{aligned}
& \text { COAL } \\
& \text { (million } \\
& \text { tons) }
\end{aligned}
$$

8

0

0

0.5

$$
\begin{array}{r}
131.8 \\
0.4 \\
0.2 \\
10.8
\end{array}
$$

ELECTRICITY

PURCHASED

(billion kWh)

*Excluding nuclear and hydro electricity, coking coal and petroleum coke, and other petroleum products not used as fuels. 
III. STATE FUEL PRODUCTION (1973) $(C-6)$

$\begin{array}{lll}\text { Type Number Units } & \text { Trillion } \\ \text { Btu }\end{array}$

Coal mines

Natural gas (liq.)

Natural gas wells

Crude oil wells

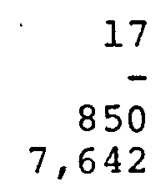

307.0

42.7

391.0

823.1

IV. GEOLOGY

Four geologic provinces exist within the borders of Wyoming: the Middle Rocky Mountains in the north central, northwestern, and western regions; the Great.Plains in the northeastern and eastern parts; the Wyoming Basin in the central and southern parts; and the Middle Rocky Mountains extending into the state between the Basin and the Great Plains.

V. RESOURCE DATA

There are no KGRAs designated in Wyoming; however, six low to moderate temperature resources have been confirmed: Audubon and Huckleberry Hot Springs, Saratoga, Countryman Well (near Lander), Thermopolis, and Cody. The northeastern portion of the state, which is underlain by the Madison aquifer, displays some near-boiling waters and is thus considered to offer potential.

Yellowstone National Park, in the northwest corner of the state, contains the world's largest concentration of hydrothermal features. Huckleberry and Audubon Hot Springs to the south of the park area, indicate temperatures suitable for generation of electricity but at depths that exceed present driliing capabilities.

VI. GEOTHERMAL ACTIVITY

Large quantities of hot water from the Madison aquifer are being used in secondary and tertiary oil recovery operations.

Four leases, totaling about 7500 acres, have been granted on federal lands, one lease (1150 acres) on state land.

A few shallow wells are used for home space heating, spas, agriculture, and fish farming.

Area development plans and site specific development plans, part of the DOE Operations Research Geothermal Planning Project are being prepared for a number of regions in the state. 
VII. LEGAI ACTIVITIES

Legislation concerning geothermal energy is being drafted for presentation in 1980 .

VIII. CONTACTS

1. State Geothermal Team:

a. Operations Research, Dr. E. Gerald Meyer (University of Wyoming);

b. Resource Assessment, Dr. Edward Decker (Department of Geology, University of Wyoming).

2. Department of Economic Planning and Development, John Niland, Executive Director.

3. State Engineer, George L. Christopulos.

4. Department of Environmental Quality, Robert E. Sundin, Director.

5. Gas and Oil Commission, Donald B. Basko, State Oil and Gas Supervisor.

6. Wyoming Geological Survey, Dr. Daniel N. Miller, Jr., state Geologist.

REFERENCES AND LIST OF SIGNIFICANT REPORTS

(1) "Wyoming Hydrothermal Commercialization Baseline," EG\&G Idaho, Inc., Jun 1979 .

COMMON REFERENCES

$(C-4),(C-6)$, and $(C-7)$. 